\title{
REGOLITHIC FINE-FRACTION WEATHERING PATTERNS \\ IN THE NORTHWEST RUBY RANGE OF THE \\ YUKON TERRITORY, CANADA
}

\author{
by \\ James E. Howes, CD, r.m.c., B.A., M.A., p.f.s.C.
}

A thesis submitted to the faculty of Graduate Studies

and Research in partial fulfillment of the requirements for the degree of

Doctor of Philosophy

Ottawa-Carleton Geoscience Center

Department of Earth Sciences

$\&$

Geotechnical Science Laboratories,

Department of Geography

Carleton University

Ottawa, Ontario

March 28, 2000

(C) copyright

2000, James Ernest Howes 
Ivaliunai Lidrary of Canada

Acquisitions and Bibliographic Services

395 Wellington Street Ottawa ON K1A ON4 Canada
Bibliothèque nationale du Canada

Acquisitions et services bibliographiques

395 , rue Wellington

Ottawa ON K1A ON4

Canada
The author has granted a nonexclusive licence allowing the National Library of Canada to reproduce, loan, distribute or sell copies of this thesis in microform, paper or electronic formats.
L'auteur a accordé une licence non exclusive permettant à la Bibliothèque nationale du Canada de reproduire, prêter, distribuer ou vendre des copies de cette thèse sous la forme de microfiche/film, de reproduction sur papier ou sur format électronique.

L'auteur conserve la propriété du droit d'auteur qui protège cette thèse. Ni la thèse ni des extraits substantiels de celle-ci ne doivent être imprimés ou autrement reproduits sans son autorisation. 


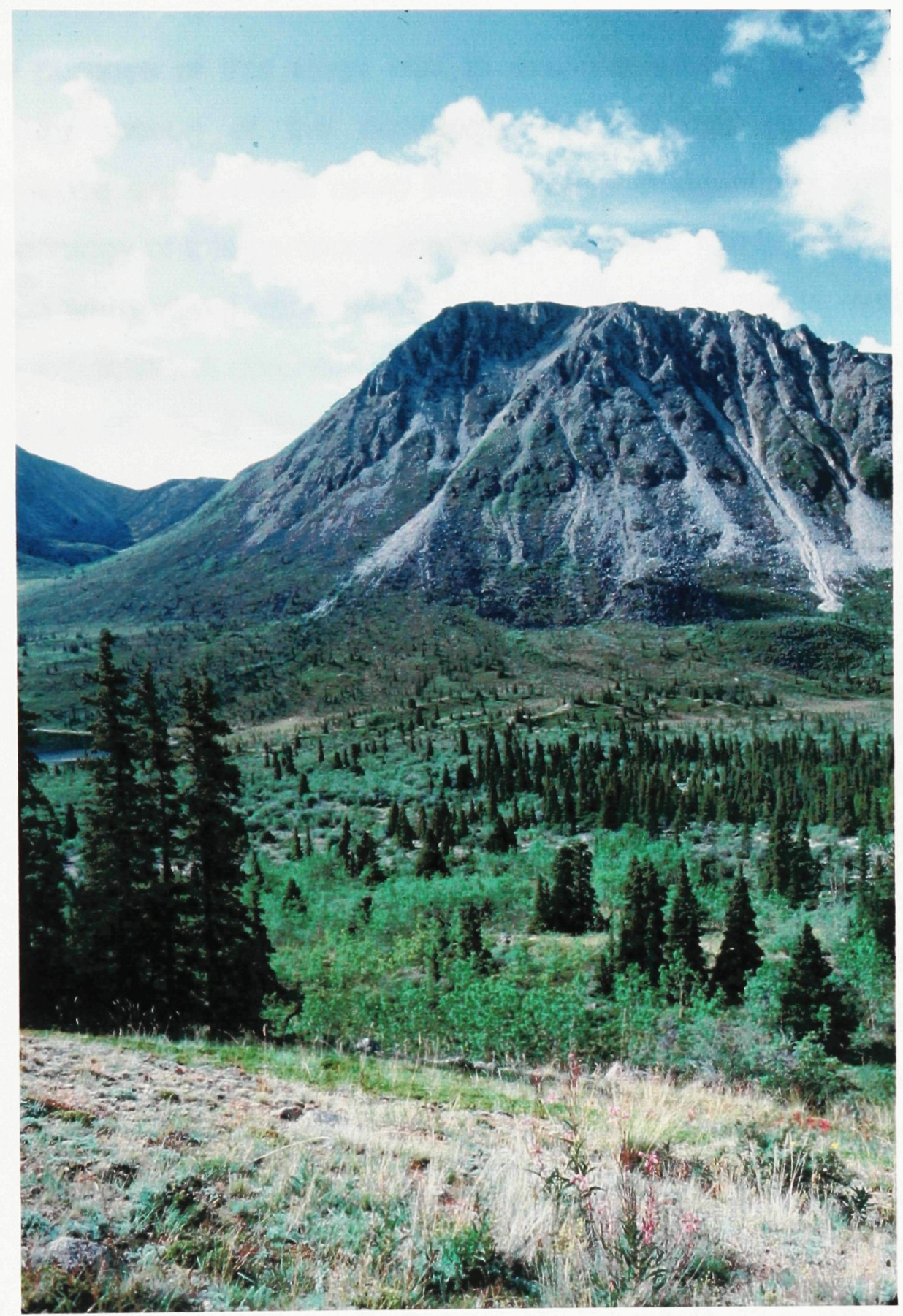

Looking southward across a glacial trough in the Gladstone Lakes section of the study area. 
The purpose of this study was to examine weathering patterns in the regolithic fine-fraction of the northwest Ruby Range to determine if a chronosequence exists which could help to resolve questions concerning the glacial chronology of this portion of the Yukon Plateau. The principal methods of investigation were visual observation, $\mathrm{X}$-ray diffraction analysis, and dithionitecitrate iron extraction. A chronosequence which could be used to date the glacial events was not identified. However, evidence was produced which indicates that all three glacial events, which left evidence of occupation within the study area, were probably stades of a single Cordilleran glacial approximately contemporaneous with the continental Wisconsinan. It was determined that the swelling of biotite during hydration provides a mechanism for unusually rapid weathering of felsic rock, and, hence, the advanced-weathering features observed at some sites gave a misleading impression of very long exposure to subaerial weathering. This study was also able to identify, through marker minerals, patterns of distribution of aeolian-transported additions (loess and volcanic ash) to the regolithic fine-fraction. In addition, widespread amounts of quartz-rich sandy glacial meltwater deposits were identified at much higher elevations than had previously been reported. When the commonly employed method of quartz normalization for $\mathrm{X}$-ray diffraction semi-quantitative analysis proved inadequate, a new method based on a 12-peak average normalization standard was developed. This proved to be especially useful in differentiating between apparent and real quartz enrichment of the regolithic fine-fraction. This method should prove useful in future studies in which the excessive variability in the quartz component of the parent material is suspected. A major limitation in using fine-fraction weathering to date glacial events is that, in a periglacial 
environment, fresh material is being continually added to older fines through congelifraction and congeliturbation within the regolith. 


\section{ACKNOWLEDGMENTS}

I would like to acknowledge the contributions of those without whose help this work would not have been possible. I would like to express my thanks to Dr. C. Wang of the Land Resource Research Centre, Agriculture Canada, who served as my mentor throughout this study, and who donated much of his personal time to advise me. He also provided both staff and resources to accomplish the iron-extraction portion of the study.

I am also grateful to three very professional technicians, Mr. B.H. Sheldrick of the Land Resource Research Center, Mr. R Conlon of the Carleton University Department of Earth Sciences, and Mr. L. Boyle of the Carleton University Department of Geography and Environmental Studies. Mr. Sheldrick tutored me in iron-extraction procedures and supervised my work throughout this phase of the study. Mr. Conlon tutored me in the operation of the Carleton University X-ray diffractometers, and produced many of the diffraction records for this study. Mr. Boyle spent several hours ingeniously hand-crafting implements for my use in the field. The contributions of these three gentleman are most gratefully acknowledged.

I would also like to thank the Carleton University Committee of the Northern Science Training Program for a series of grants which significantly eased the financial burden of my field expenses.

For their contributions to my work in the field, I would like to acknowledge and thank Mr. A. Williams and the staff of the Arctic Institute of North America Research Station at the Kluane Lake Landing Strip, Mr. Thomas Joe who is an elder of the Champagne-Aishihik Band, and Mr. T. Churchill who owns and operates the placer mining operation on Fourth of July Creek. Mr. Williams provided much of the logistic support for the field work and served as my radio link to the outside world. Mr. Thomas Joe, who at the age of seventy-five, was still hunting alone throughout the Ruby Range, imparted a wealth of information 
on survival skills and provided me with a constant source of inspiration during the more difficult times. Mr. Churchill allowed me unrestricted access to his property, and provided valuable information on the structure and composition of glacial deposits within the area.

I would also like to express my sincere appreciation to Professor J.K. Torrance, Department of Geography and Environmental Studies, Carleton University; Professor J.P. Johnson Jr., Department of Geography and Environmental Studies, Carleton University; Professor P.G. Johnson, Department of Geography, Ottawa University; and Professor F.A. Michel Department of Earth Sciences, Carleton University, who jointly served as my supervisory committee. They gave most generously of their time and energy, and their collective insight and experience were invaluable.

Finally, I would like acknowledge and to express my heartfelt gratitude to my wife, Magdalena, for her innumerable contributions. She cheerfully accepted my prolonged absences from home and demonstrated great patience with my bouts of preoccupation and absent-mindedness when I returned. She also worked for hours with me in the laboratory, and assisted me in the final preparation of this thesis. It is to her with love that I dedicate this work.

J.E.H. 


\section{TABLE OF CONTENTS}

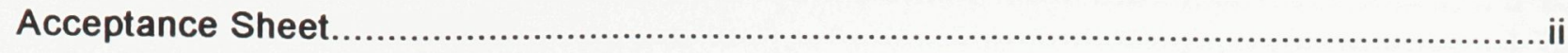

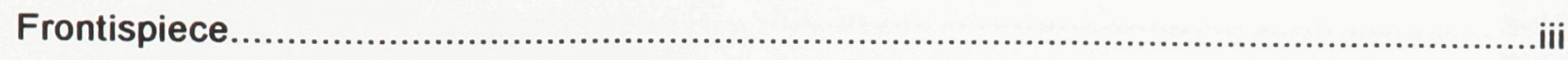

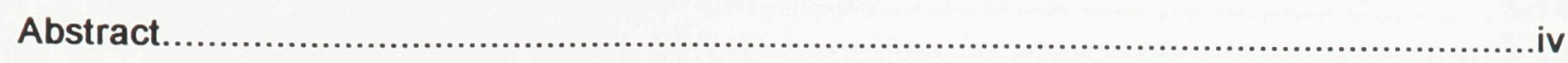

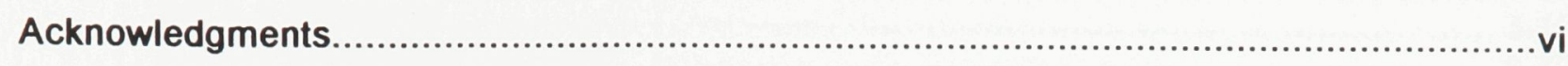

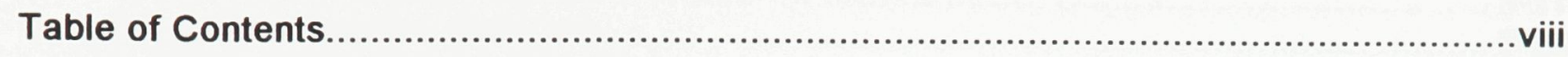

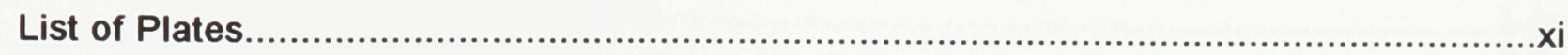

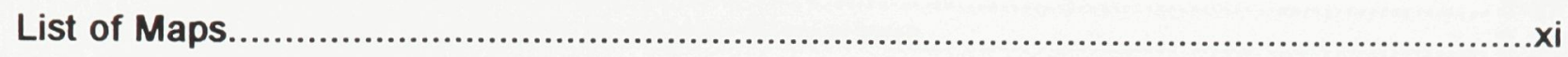

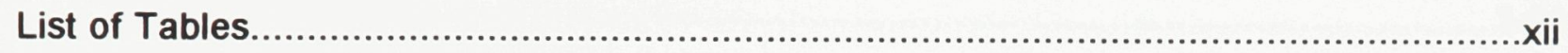

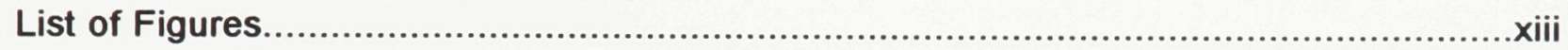

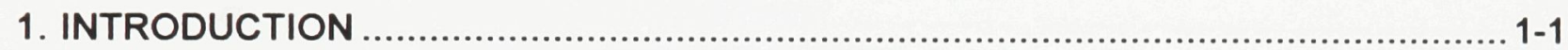

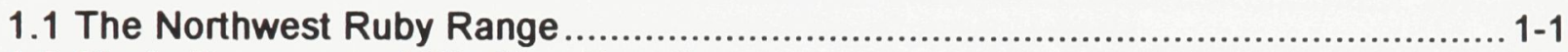

1.2 Study Purpose and Working Hypotheses..................................................... 1-1

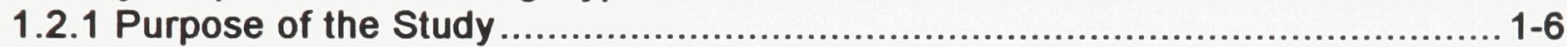

1.2.2 The Chronosequence Hypothesis ...................................................... 1-6

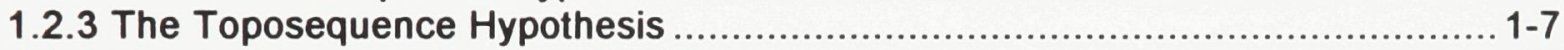

1.2.4 The Additional-materials Hypothesis .................................................... 1-7

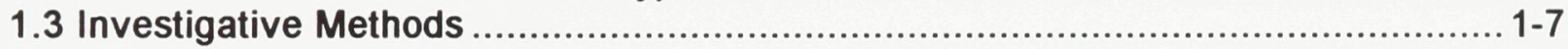

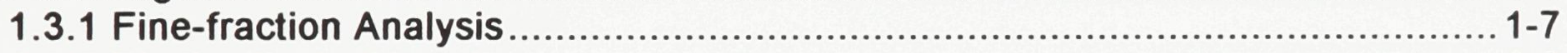

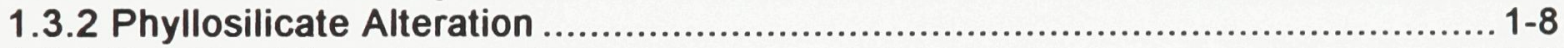

1.3.3 Relative Mineral Abundance ........................................................ 1-9

1.3.4 Pedogenic Iron Oxide Content ..................................................... 1-9

2. CLIMATE, PHYSIOGRAPHY AND GLACIATION ....................................... $2-1$

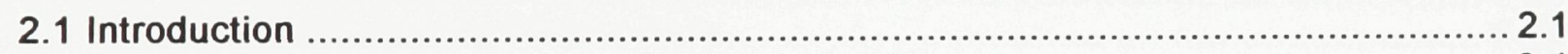

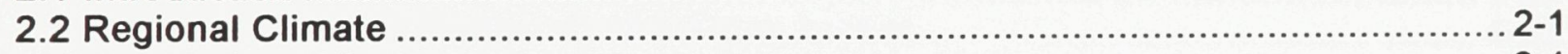

2.2.1 Modern Climate........................................................................ 2-1

2.2.2 Regional Paleoclimate .................................................................. 2-6

2.3 Regional Landscape Development......................................................... 2-9

2.3.1 The Yukon Plateau .........................................................................

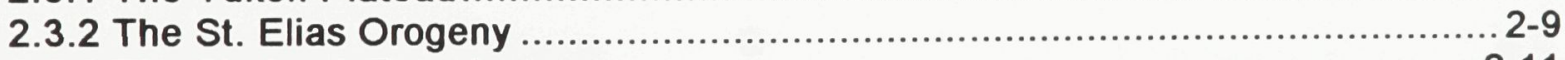

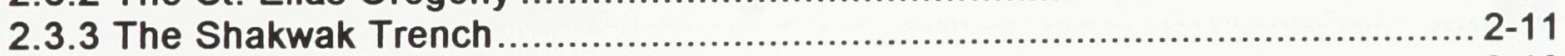

2.3.4 Alteration of Precipitation Distribution ................................................ 2-13

2.4 Glaciation $\ldots$

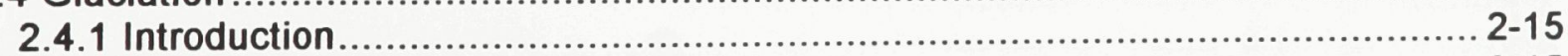

2.4.2 General Interpretation Difficulties ..................................................... 2-15

2.4.3 Regional Glacial Sequences...................................................... $2-18$

2.4.4 Muller's Glacial Sequence ......................................................... $2-19$

2.4.5 Denton's Glacial Sequence ........................................................ 27

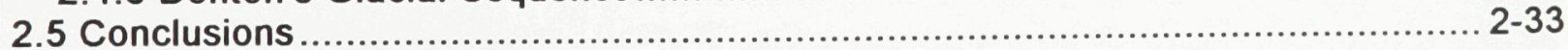

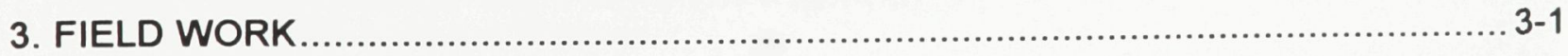

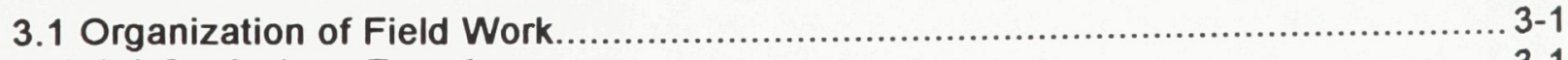

3.1.1 Study Area Zonation..................................................................... 


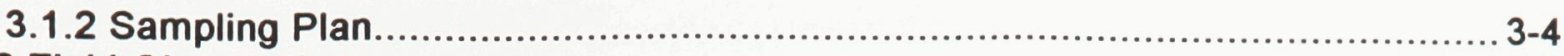

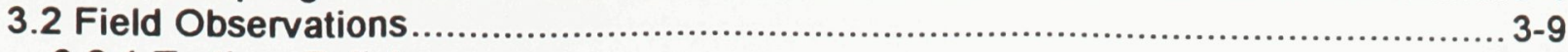

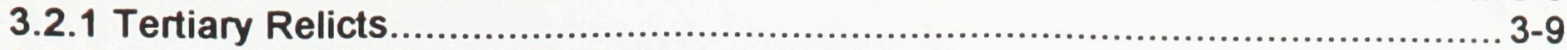

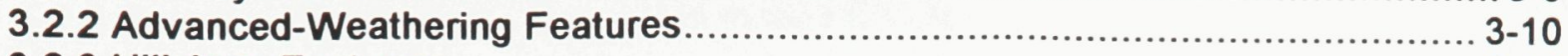

3.2.3 Hillslope Features ........................................................................ 3-12

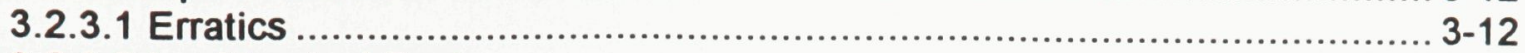

3.2.3.2 Ice-Marginal Features ............................................................. 3-14

3.2.4 Valley Bottom Features ................................................................... 3-16

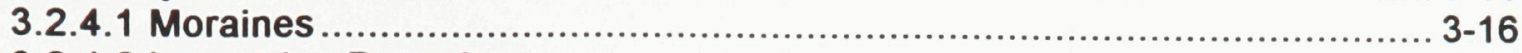

3.2.4.2 Lacustrine Deposits ............................................................... 3-17

3.2.5 Fine-Fraction Materials..................................................................... 3-20

3.2.5.1 Fine-Fraction Profiles ............................................................ 3-20

3.2.5.2 Clay-Rich Horizons ............................................................... 3-21

3.2.5.3 Loess Deposition at Higher Elevations....................................... 3-22

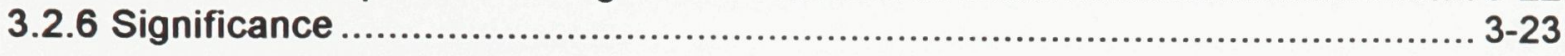

4. PHYLLOSILICATE ALTERATION............................................................

4.1 Benchmark Selection ........................................................................... 4

4.1.1 Alteration in Polar Desert Conditions..................................................... 4-1

4.1.2 Alteration in Temperate Montane Regions ............................................. 4-2

4.1.3 Alteration in Late- and Post-Wisconsinan Canadian Soils .......................... 4-3

4.1.4 Alteration in Pre-Wisconsinan Canadian Soils ........................................ 4-4

4.1.5 Alteration in the Central Yukon ............................................................. 4-6

4.2 Investigative Methods .......................................................................... 4-6

4.2.1 Gibbsite Identification........................................................................ 4-7

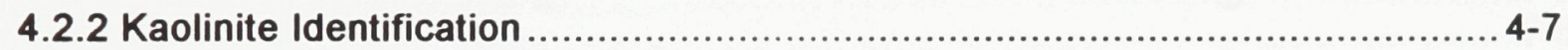

4.2.3 Smectite Identification.................................................................... 4

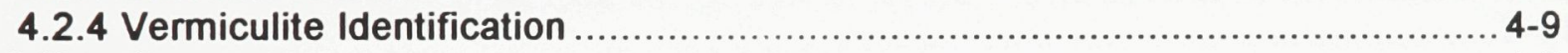

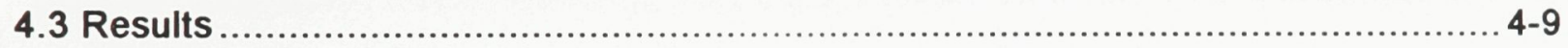

4.3.1 Presence of Gibbsite and Kaolinite .................................................... 4-9

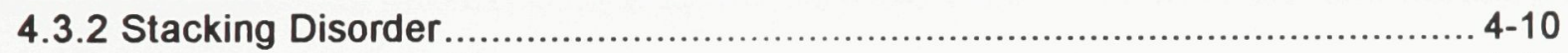

4.3.3 Presence of Smectite ........................................................... 4-14

4.3.4 Presence of Vermiculite ........................................................... 4-16

4.3.5 Distribution of Alteration Occurrences ........................................... 4-26

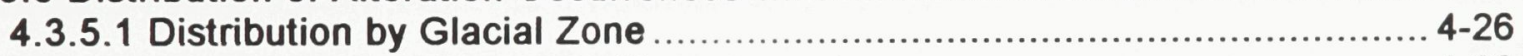

4.3.5.2 Alteration Frequency and Slope Aspect .................................... 4-26

4.3.5.3 Alteration Frequency and Dominant Vegetation Cover ...................... 4-28

4.3.5.4 Alteration Frequency and Slope Angle ..................................... 4-29

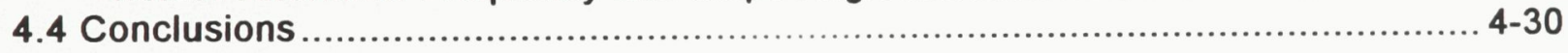

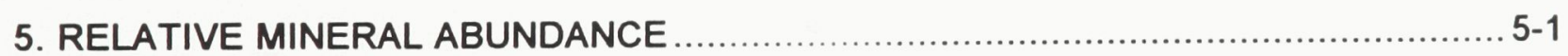

5.1 Investigative Methods ........................................................................ 5

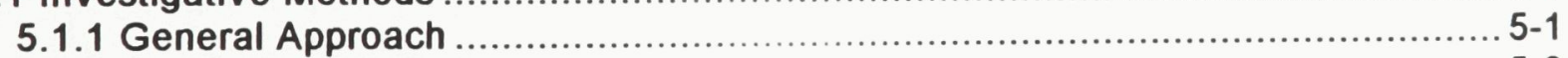

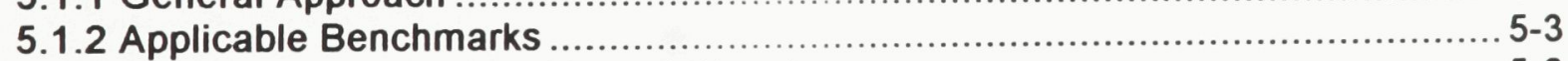

5.1.3 Sample Preparation for X-ray Diffraction ................................................

5.1.4 Verification of Parent-Material Composition ......................................... 5-9

5.1.5 Quantitative Measurement........................................................ 5-10

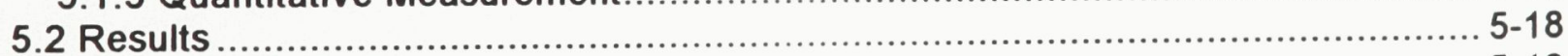

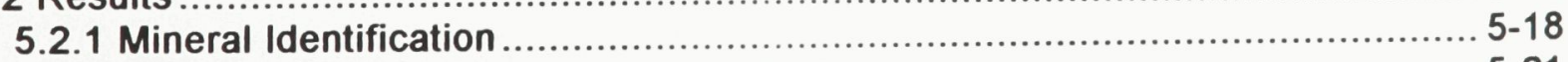

5.2.2 Parent Materials and Subsequent Additions......................................... 5-21

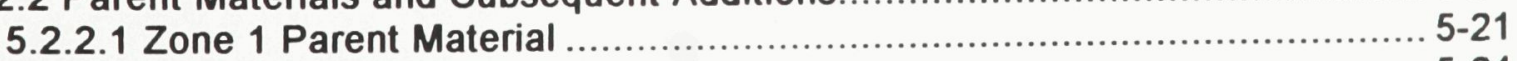

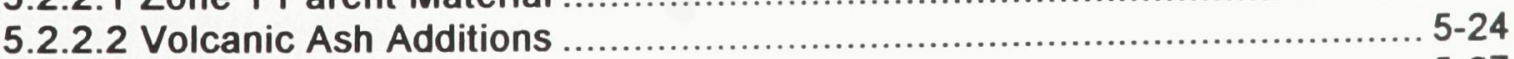

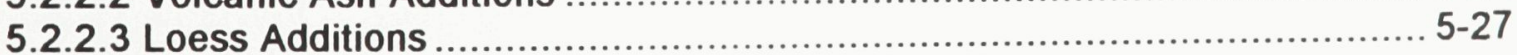


5.2.2.4 Zone 2 Parent Material ............................................................

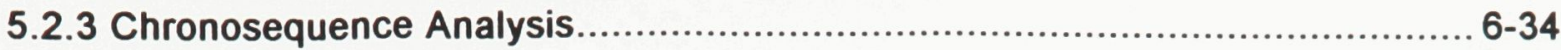

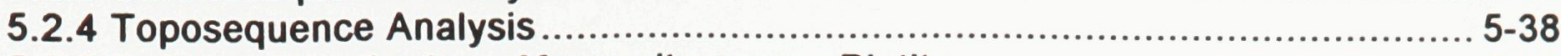

5.2.5 Relative Weathering - Muscovite versus Biotite ................................ 5-48

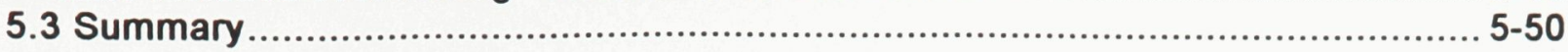

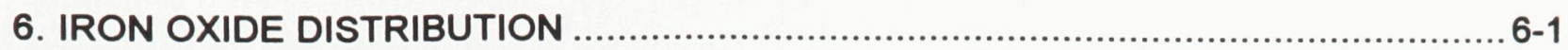

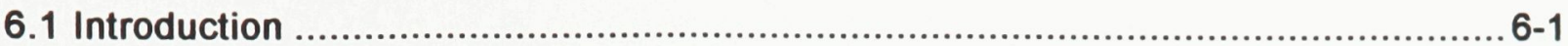

6.1.1 Formation of Iron oxides..........................................................................

6.1.2 Iron Oxide Benchmarks .............................................................................

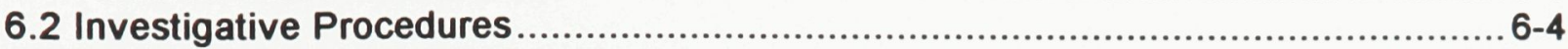

6.2.1 Iron Oxide Extraction Methods......................................................... 6-4

6.2.2 Dithionite-Citrate Extraction Procedures............................................. 6-5

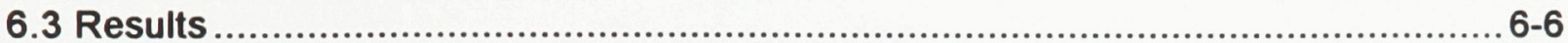

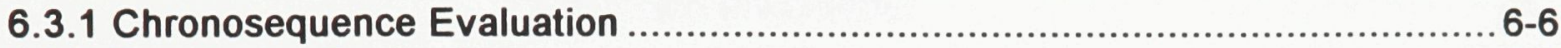

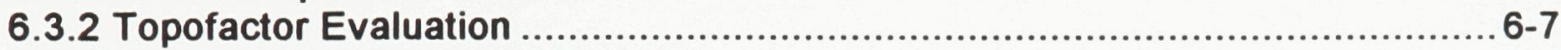

6.3.2.1 Extracted Iron and Elevation ...................................................... 6-8

6.3.2.2 Extracted Iron and Slope Angle ................................................. 6-8

6.3.2.3 Extracted Iron and Slope Aspect ..................................................... 6-8

6.3.2.4 Extracted Iron and Ground Cover.................................................. 6-9

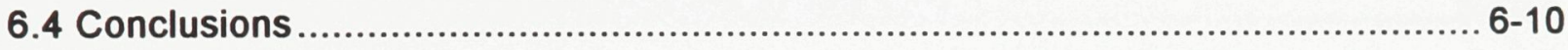

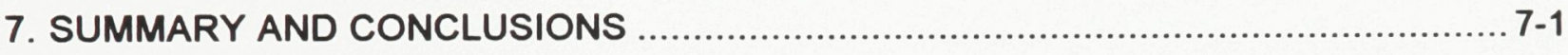

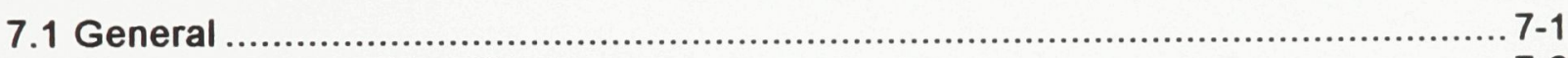

7.2 Chronosequence Hypothesis .............................................................. $7-2$

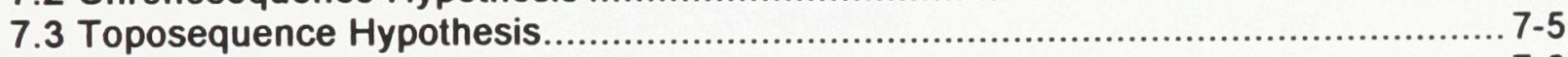

7.4 Additional Materials Hypothesis ............................................................. $7-8$

7.5 Contributions ................................................................................. 71

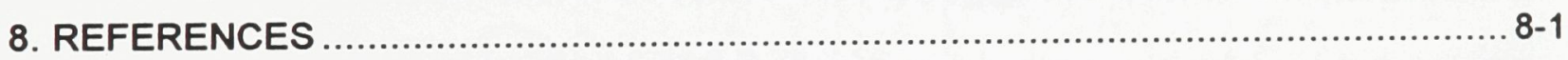

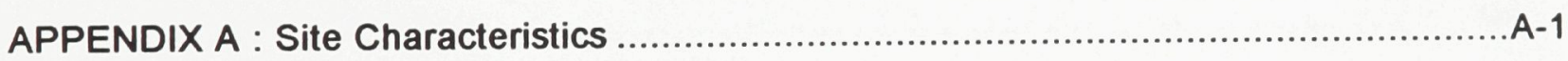

APPENDIX B : Relative Mineral Abundance Data .................................................

APPENDIX C : Extractable Iron Content ....................................................... 


\section{LIST OF PLATES}

Plate 1: Glacial trough in the Gladstone Creek section of the study area..........................1-5

Plate 2: Tertiary diamicton deposit on Amphitheatre Mountain........................................2-12

Plate 3: Terraces in the Post-glacial Ground Surface Zone..............................................3-19

\section{LIST OF MAPS}

Map 1.1: Location of the northwest Ruby Range study area.................................. 1-2

Map 1.2: The northwest Ruby Range and adjacent physiographic units....................... 1-3

Map 2.1: Selected regional weather reporting centers..................................................... 2-4

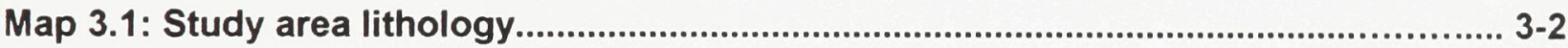

Map 3.2: Study area ground surface zones...................................................................... 3-3

Map 3.3: Transect lines superimposed on a map of study area lithology......................... 3-5

Map 3.4: Transect lines superimposed on a map of study area ground surface zones.....3-7 


\section{LIST OF TABLES}

Table 2.1: Modern Climate Statistics..................................................................

Table 2.2: Various Northern Cordilleran Glacial Sequences.................................2-23

Table 2.3: Correlations to Cordilleran and Continental Sequences.........................2-26

Table 2.4: Approximate Onset Dates (yrs. B.P.) for Key Events..............................2-32

Table 3.1: Northwest Ruby Range Study Area Ground Surface Zones ........................3-4

Table 3.2: Distribution of Lithological Zone 1 Sites by Ground Surface Class................3-6

Table 3.3: Profile of a loess deposit at the mouth of Cultus Creek.............................20

Table 4.2: Ethylene Glycol Solvation Test Results........................................4-12

Table 4.3: Sites Selected for K-Saturation Testing........................................ 4-17

Table 4.4: Distribution by Ground Surface Zone of Alteration Occurrences..................4-26

Table 4.5: Frequency of Alteration Occurrences by Slope Aspect............................4-28

Table 4.6: Alteration Frequency by Dominant Vegetation Cover Class.......................4-29

Table 5.1: Distribution of clay-fraction minerals in Eastern Wright Valley.....................5-15

Table 5.2: Indicated coefficient of variation (\%) in muscovite-bearing schist bedrock.....5-14

Table 5.3: Diffraction energy distribution..................................................... 5-17

Table 5.4: Selected muscovite-bearing schist peaks for 12-peak normalization.............5-17

Table 5.5: Relative intensity of $00 /$ peaks of dioctahedral micas............................5-20

Table 5.6: Relative intensities of the $00 /$ peaks of trioctahedral micas.......................5-20

Table 5.7: Summary of calcite occurrences in Zone 1 fines.................................5-28

Table 5.8: Comparison of four loess-free Post-glacial samples to unadulterated loess...5-33

Table 5.9: Comparison of fines to bedrock samples in the muscovite-schist zone..........5-35

Table 5.10: Student's $t$-test summary ground surface zonal differences.....................5-36

Table 5.11: Indicated fine-fraction mineral depletion in the muscovite-schist unit.........5-37

Table 6.1: Mean Extracted Iron by Ground Surface Zone....................................6-6

Table 6.2: Student's $t$ Tests of Extracted Iron Distribution by Ground Surface Zones......6-7

Table 6.3 : Extracted Iron and Elevation Correlations........................................6-8

Table 6.4: Summary of Mean Extracted-Iron Level by Slope Aspect...........................6-9

Table 6.5: Mean Extracted-Iron Level (\%) by Ground Cover Class..............................6-9

Table 6.6: Student's $t$ Tests of Extracted-Iron Distribution by Ground Cover Class.........6-9 


\section{LIST OF FIGURES}

Figure 4.1: Example of a raised baseline or "plateau" between 10 and $14 \AA$................4-11

Figure 4.2: An example of a broad diffuse peak between 10 and $14 \AA \ldots \ldots \ldots \ldots \ldots \ldots \ldots . . . . . .12$

Figure 4.3: Effect of glycol solvation on sample from Site 1C4a...........................4-15

Figure 4.4: Partial collapse of "plateau" after heat treatment.................................4-19

Figure 4.5: Collapse of $12 \AA$ reflection following heating ......................................4-20

Figure 4.6: Effect of heat pre-treatment on a sample containing very little chlorite.......4.21

Figure 4.7: Sample from Site $1 \mathrm{C} 4$ heated to $700^{\circ} \mathrm{C}$ without $\mathrm{K}$-saturation pre-treatment..4-24

Figure 4.8: Effects of heat on sample from Site 2A1 without K-saturation pre-treatment.4-25

Figure 5.1: X-ray diffraction record of a sample of White River volcanic ash...............5-15

Figure 5.2: X-ray diffraction records from Site 1B6..........................................

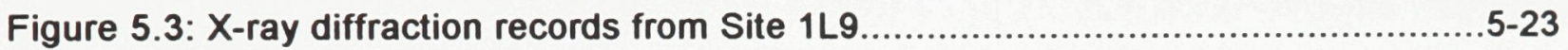

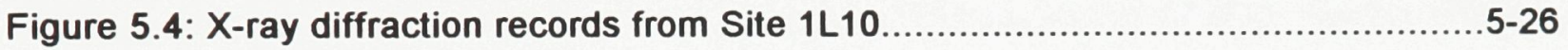

Figure 5.5: X-ray diffraction record of a sample of Neoglacial (Holocene) loess...........5-29

Figure 5.6: $X$-ray diffraction record of a fine-fraction sample from site $1 \mathrm{~K} 9 \ldots \ldots \ldots \ldots \ldots \ldots . . . . . . .31$

Figure 5.7: $X$-ray diffraction records of 3 rock samples from site $2 A 1 \ldots \ldots \ldots \ldots \ldots \ldots \ldots \ldots .5-32$

Figure 5.8: $7 \AA$ peak intensities ratios (12-peak normalization) ..............................5-39

Figure 5.9: $5 \AA$ peak intensity ratios (12-peak normalization) ...............................5-41

Figure 5.10: $4.26 \AA$ peak intensity ratios (12-peak normalization) ...........................5-43

Figure 5.11: 8.4 and $3.19 \AA$ fine-fraction peak intensity ratios (12-peak normalization)....5-47 


\section{INTRODUCTION}

\subsection{The NorthWEst Ruby Range}

The northwest Ruby Range study area in the southwest Yukon Territory, Canada, is located some $260 \mathrm{~km}$ west of Whitehorse along the Alaska Highway (Map 1.1). The Ruby Range is a physiographic sub-unit of the Yukon Plateau and in terms of topography is characteristic of the whole unit. The plateau surface has been deeply incised so that the modern topography of the Ruby Range consists of an approximately $125 \mathrm{~km}$ long and $35 \mathrm{~km}$ wide belt of mainly flat-topped hills trending southeasterly from the northeastern shore of Kluane Lake. Elevations range from 800 to $2300 \mathrm{~m}$.

The Ruby Range is bounded on the northeast by the parallel-trending Nisling Range, another sub-unit of the Yukon Plateau, with similar topography (Map 1.2). On the southwest, the Ruby Range is bounded by the Shakwak Trench, a graben up to $8 \mathrm{~km}$ in width, in which Kluane Lake is situated. To the southwest side of the Shakwak Trench lie the Kluane Ranges, the front ranges for the St. Elias Mountains which extend some $200 \mathrm{~km}$ southwestward to the Gulf of Alaska. In modern times, the St. Elias Mountains create a rain-shadow for this portion of the Yukon Plateau.

The study area consists of a $1,130 \mathrm{~km}^{2}$ block of the northwestern portion of the Ruby Range (Map 1.2). This block is bounded on the west and southwest by an approximately $35 \mathrm{~km}$ of the Kluane Lake shoreline. In the south, the 


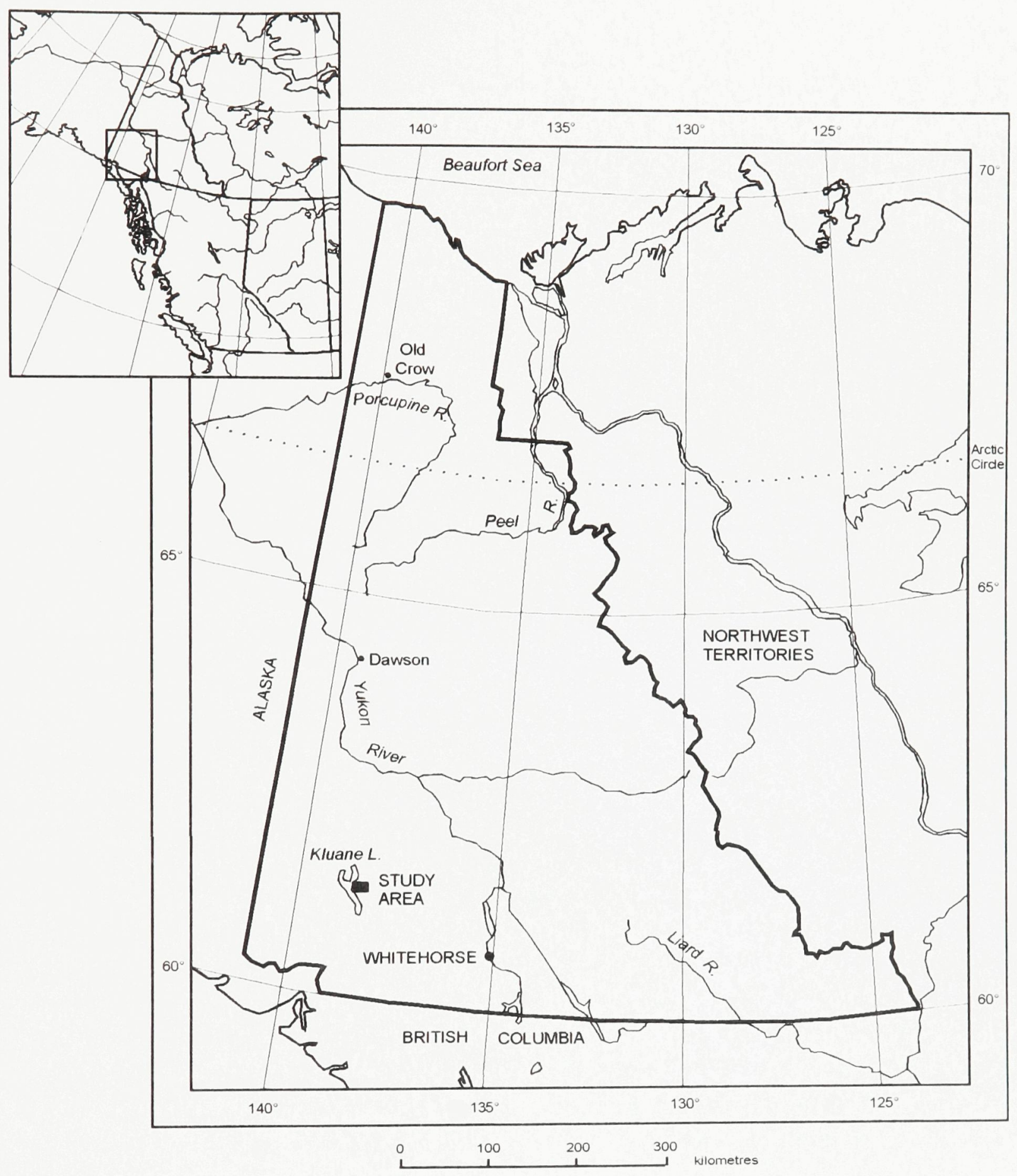

Map 1.1: Location of the northwest Ruby Range study area. 
$1-3$

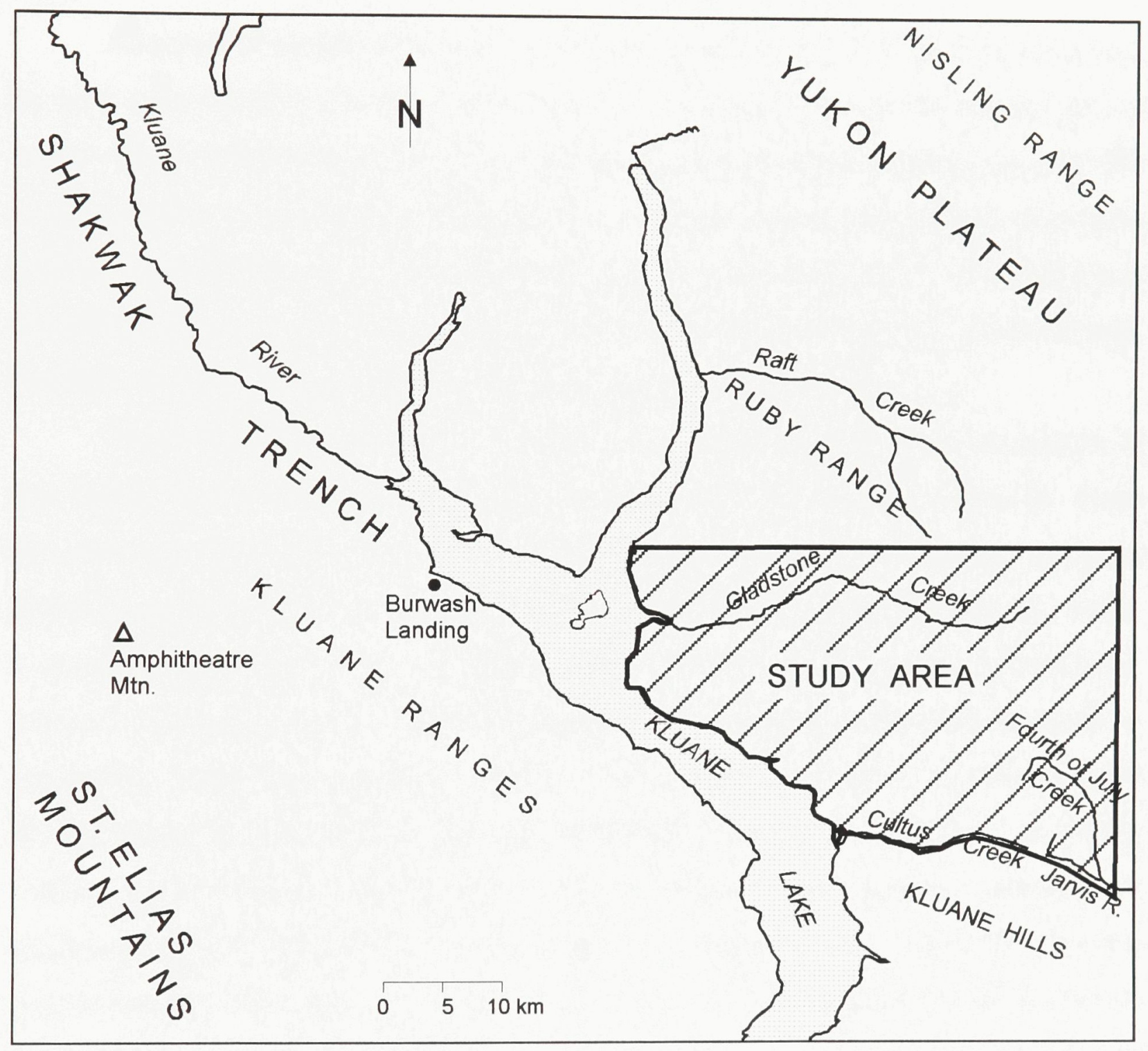

Map 1.2: The northwest Ruby Range and adjacent physiographic units. 
study area is bounded by Cultus Creek and Jarvis River, and to the east by the east side of the Fourth of July Creek valley. The northern boundary of the study area is an arbitrarily selected line $30 \mathrm{~km}$ north of the Cultus Creek and Jarvis River.

Analysis of aerial photography reveals evidence of three glacial advances as was postulated by Muller (1967). Earlier studies of the glacial history of the region have relied heavily on visual evidence. The literature arising out of these studies, which is reviewed in Chapter Two, leaves several unresolved questions concerning whether or not these advances were all stadials of one glaciation contemporaneous with the Wisconsinan (Last Glaciation); or, alternatively, whether the early advances were events from earlier glaciations.

The literature reviewed in Chapter Two indicates that tectonic events in the region during the Cenozoic were dominated by the steadily rising St. Elias Mountains to the west. These mountains are now capturing increasing amounts of the precipitation which in earlier times would have fallen on the plateau itself. It is postulated that, during successive late-Tertiary and Quaternary glaciations, the flow of ice eastward towards the plateau has increased with each successive glaciation, while the quantity of ice, which accumulated on the plateau itself during these glacial events, has simultaneously declined. The work of Muller (1967) and Denton and Stuiver (1967) suggest just such a pattern of accumulation and flow has occurred. It may be hypothesized, however, that the glacial events described by these researchers, and subsequently attributed to the late Quaternary, may actually have occurred over a much longer timespan than they envisioned. It is that question specifically which this study seeks to address. 


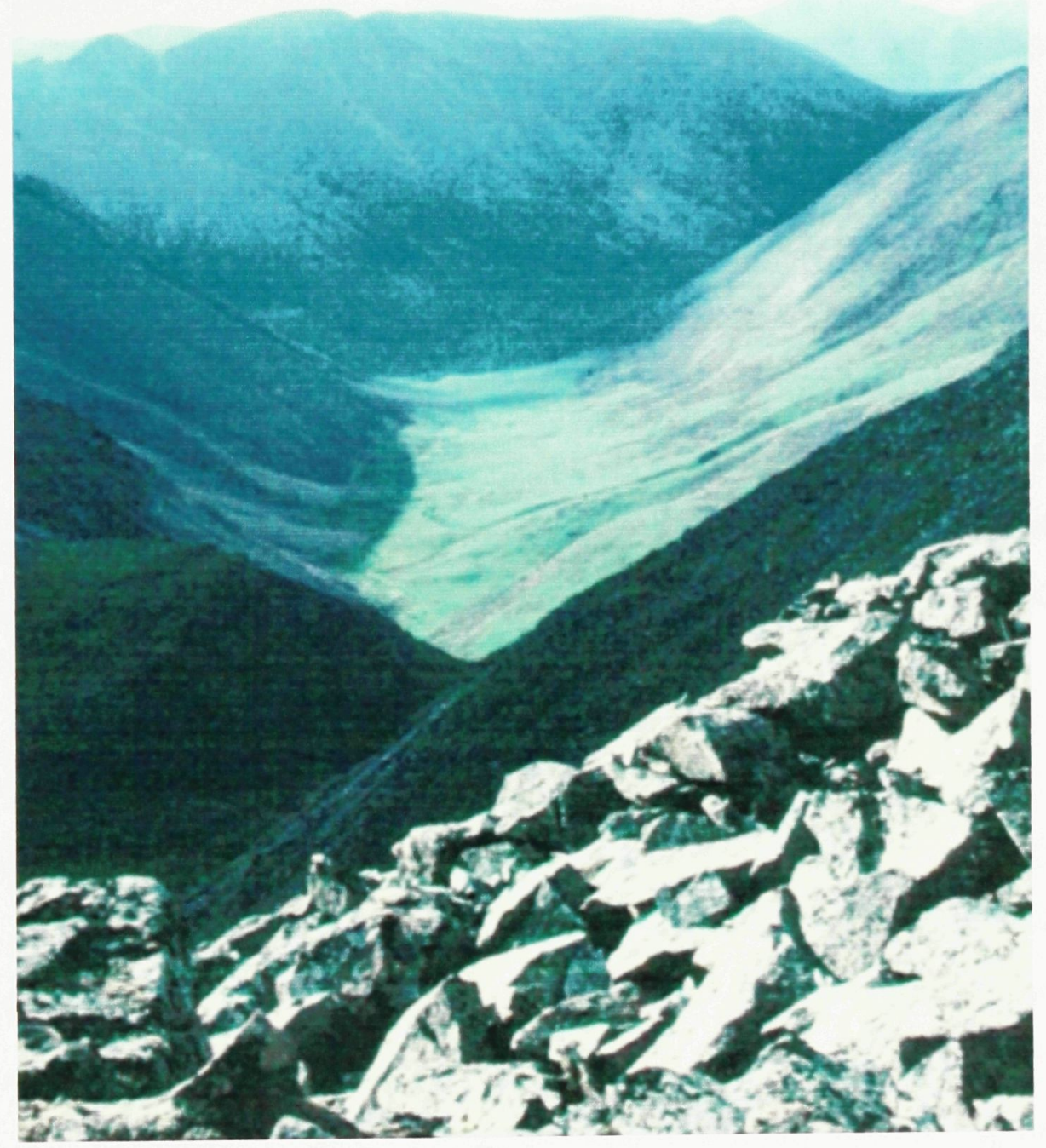

Plate 1: Looking westward along a glacial trough in the Gladstone Creek section of the study area. 


\subsection{STUdY PURPOSE AND WORKING HYPOTHESES}

\subsubsection{Purpose of the Study}

The purpose of this study is to examine weathering patterns in the regolithic fine-fraction of the northwest Ruby Range to determine if a chronosequence exists which can help to resolve questions concerning the glacial chronology of this portion of the Yukon Plateau. In this context, the term, "regolithic fine-fraction", is interpreted to mean that fraction of the non-organic content of the regolith whose particle diameters do not exceed $2 \mathrm{~mm}$. The methodology adopted for this study is the "Method of Multiple Working Hypotheses" as originally advocated by Chamberlin (1890) for the conduct of scientific research. To this end, three working hypotheses were formulated with respect to the regolithic fine-fraction weathering patterns of the Northwest Ruby Range: a "chronosequence hypothesis", a "toposequence hypothesis" and an "additional-materials hypothesis". These hypotheses are not considered to be mutually exclusive of one another.

\subsubsection{The Chronosequence Hypothesis}

Weathering patterns in the fine-fraction materials mantling the study area regolith will form a discernible chronosequence reflecting the glacial history of the bedrock surfaces on which they currently rest. This hypothesis assumes that the most advanced weathering will be found in the fine-fraction materials mantling the oldest surfaces. It is anticipated that the degree of weathering of the fine-fraction materials will indicate (if not in the absolute sense, at least in the relative sense) the age of the associated bedrock surfaces. In this way, the fine-fraction weathering patterns will help to resolve current uncertainties concerning the glacial chronology of the region. 


\subsubsection{The Toposequence Hypothesis}

If a chronosequence exists in the fine-fraction material, its characteristics may be masked in whole or in part by topographically induced weathering patterns. It is anticipated that the most likely topographic factors to produce strong weathering patterns would be elevation, slope angle, slope aspect and vegetation cover.

\subsubsection{The Additional-materials Hypothesis}

If a chronosequence and/or a toposequence does exist, the weathering characteristics of either sequence could be masked in whole or in part by additional fine-fraction materials. From the literature reviewed and from observations in the field, it was anticipated that the bulk of these additions would be in form of loess, volcanic ash, and glacial deposits.

\subsection{InVestigative Methods}

\subsubsection{Fine-fraction Analysis}

Although the use of fine-fraction weathering to date glacial deposits is a common practice (Birkeland,1984; Bockheim,1979; Evans and Cameron, 1979; Wang and Ross; 1989), attempts to use the weathering of fine-fraction materials to date a glaciated ground surface in the absence of such deposits are less common. Only two examples were found in the literature surveyed. R. Dahl is reported to have used chemical analysis of fine-fraction materials in estimating the age of mountain-top blockfields in the Narvik-Skjomen area of Norway in order to determine whether or not these ground surfaces had been overridden by glacial ice (Ives,1966). Dahl is also reported to have used X-ray diffraction to identify altered phyllosilicates (vermiculite, hydrobiotite, and montmorillonite). From the abundance of these minerals in the fine-fraction of mature Labrador mountain-top detritus, he concluded that warm climate weathering processes 
equivalent to those which are believed to have prevailed during the Tertiary would have been required to produce such an advanced stage of weathering, and hence these surfaces could not have been glaciated since the Tertiary (Ives, 1963).

This study differs from the studies cited above in the extent of the sampling. Both the studies relating to the weathering of glacial deposits and the two studies by Dahl relating to the age of mountain-top blockfields were based on a limited number of specific sites. In this study, sampling was conducted at a total of 171 sites along 21 transects over a $1,130 \mathrm{~km}^{2}$ block of terrain. The purpose of such extensive sampling was to ensure that the northwest Ruby Range would be as adequately represented as possible by the sample populations, and that these populations would be of sufficient size that proper statistical verification could be conducted to confirm any trends that might emerge from the data.

Despite reservations related to the small numbers of samples used in previous studies of fine-fraction materials, certain of these data were found to be of some use in the current study. Those conducted in regions in which current climate conditions are comparable to those which prevail within the Northwest Ruby Range study area were consulted in an effort to develop benchmarks by which to gauge the approximate age of the fine-fraction samples collected in the course of the current study. In the end, however, this study relied upon statistical verification of weathering trends observed within the current study area. Sampling methods and observations relating to field observations and an air photo study are outlined in Chapter Three.

\subsubsection{Phyllosilicate Alteration}

One of the principal weathering characteristics studied was that of the alteration of primary phyllosilicate minerals to secondary mineral species. The identification of secondary minerals was achieved through $X$-ray diffraction comparison of fine-fraction samples to selected local bedrock samples. The 
literature review indicated that the principal weathering products should be vermiculite, smectite, gibbsite, and kaolinite, none of which are found in the local bedrock. It was planned to determine the degree of weathering by measuring the intensity of the characteristic $X$-ray diffraction peaks for these minerals in individual samples, or if this did not prove feasible, the alternative approach would be to study the frequency of alteration occurrences within groups of sites. The details of the phyllosilicate alteration study are reported in Chapter Four.

\subsubsection{Relative Mineral Abundance}

The second weathering characteristic studied was the abundance of the component minerals of the fine-fraction material compared to the abundance of the same minerals in local bedrock outcrops. Since the component minerals of the fine-fraction material will all weather at different rates, the current mineral composition of a fine-fraction sample is indicative of the degree of both physical and chemical weathering to which that sample has been subjected. Relative depletion was estimated through a semi-quantitative analysis of relative mineral abundance as determined from a comparison of the $X$-ray diffraction records of the fine-fraction samples to a baseline derived from representative bedrock samples. In order to make the comparisons of relative mineral abundance, it was necessary to develop a new normalization standard to replace the conventional quartz standard due to conditions peculiar to the lithology of this study area. The details of the relative mineral abundance study are reported in Chapter Five.

\subsubsection{Pedogenic Iron Oxide Content}

The third weathering characteristic studied was the accumulation of pedogenic iron oxides in fine-fraction samples. The dithionite-citrate chemical extraction process was employed on groups of samples selected to ensure an adequate representative sampling from each of the zones in the anticipated 
chronosequence. In view of limitations on the number of chemical extractions which could be performed, an attempt was made to establish a correlation between measured extractable-iron content and sample rubification in order to determine if rubification could serve as a reliable surrogate indicator for extractable iron. The details of the pedogenic iron oxide study are reported in Chapter Six.

A summary of the main points and the conclusions drawn from all three studies is presented in Chapter 7. 


\section{CLIMATE, PHYSIOGRAPHY AND GLACIATION}

\subsection{INTRODUCTION}

In the opinion of some modern researchers, ice volumes of successive glaciations on the Yukon Plateau have been controlled throughout the late Cenozoic by the progressive development of a rain shadow resulting from the western cordilleran uplift (Eisbacher and Hopkins, 1977; Ruddiman et al., 1988; Ruddiman and Kutzbach, 1989; Kutzbach et al., 1989; and Burn, 1994). This chapter explores the applicability of this theory to the northwest Ruby Range and adjacent physiographic units, and the implications of this theory with respect to the chronosequence hypothesis.

\subsection{Regional Climate}

\subsubsection{Modern Climate}

The modern continental climate regime of the Yukon interior is attributed to the blocking effect of the western Cordillera (Wahl et al., 1987). Large portions of the St. Elias mountains in the southwest Yukon have elevations in excess of $3500 \mathrm{~m}$, a level below which lies one-third of the total atmospheric mass, and these mountains effectively block westerly airflow off the Gulf of Alaska (Burn,1994). The result of this blockage is the dominance of a large high pressure cell over the Yukon Plateau during the winter, spring and early 
summer. In late summer and fall, the jet stream carries a series of low pressure cells into the Gulf of Alaska, and some moist air penetrates into the interior (Wahl et al., 1987).

The data presented in Table 2.1 reveal trends in regional temperature and precipitation distribution as reflected in the temperature and precipitation means of reporting centers at different elevations and distances from the coast. Continentality increases with distance from coast; e.g., mean January temp. for Whitehorse which lies approximately $240 \mathrm{~km}$ from the coast is $-20.9^{\circ} \mathrm{C}$ whereas some $250 \mathrm{~km}$ further inland at Mayo (Map 2.1), it is nine degrees colder (Burn, 1994). A combination of lack of solar heating in winter and cold air drainage renders very low winter temperatures in valley bottoms; e.g., Keno Hill (elevation $1472 \mathrm{~m}$ ) has a mean daily temperature for January which is over $9^{\circ} \mathrm{C}$ warmer than Mayo (elevation 504m) located only $50 \mathrm{~km}$ away. Valley bottoms on the Yukon Plateau are snow-free by early May, but snow cover persists for an extra month in upland areas. Normal temperature lapse rates apply in summer time (Burn, 1994).

Although long term-weather data have not been compiled for the Ruby Range study area, the data compiled by Environment Canada for nearby Burwash Landing should provide a useful analogue. On this basis, the mean January valley bottom temperature within the study area should be approximately $-30^{\circ} \mathrm{C}$. In July, when normal temperature lapse conditions prevail, the mean July temperature range for the study area should be approximately $13^{\circ} \mathrm{C}$ in the valley bottoms, and, taking into account the environmental lapserate, should be approximately $5^{\circ} \mathrm{C}$ at upland sites.

Regional precipitation is controlled, particularly in the winter months by the St. Elias rain shadow; e.g., Whitehorse receives only about one-quarter of the annual precipitation of Juneau on the coast. The rain shadow effect is somewhat ameliorated during the summer months by local convective air 
Table 2.1: Modern Climate Statistics

(Selected stations in Yukon and Alaska)

Monthly Mean Air Temperature $\left({ }^{\circ} \mathrm{C}\right)$

Juneau Whitehorse Mayo Keno Hill Burwash

$\begin{array}{lccccc}\text { January } & -5.4 & -20.9 & -29.9 & -19.6 & \text { Landing } \\ \text { February } & -2.2 & -12.9 & -19.9 & -13.9 & -23.7 \\ \text { March } & -0.1 & -7.4 & -11.7 & -13.7 & -14.5 \\ \text { April } & 4.0 & 1.0 & -0.4 & -6.6 & -5.4 \\ \text { May } & 8.2 & 6.7 & 7.5 & 1.4 & 3.5 \\ \text { June } & 11.7 & 12.1 & 13.4 & 7.8 & 10.5 \\ \text { July } & 13.2 & 14.5 & 15.2 & 10.0 & 13.3 \\ \text { August } & 12.6 & 12.6 & 12.6 & 7.9 & 10.0 \\ \text { September } & 9.6 & 7.8 & 6.5 & 2.0 & 6.1 \\ \text { October } & 5.4 & 1.3 & -2.3 & -6.3 & -6.2 \\ \text { November } & 0.3 & -9.4 & -15.2 & -12.3 & -14.9 \\ \text { December } & -3.0 & -17.1 & -24.2 & -16.9 & -18.0 \\ & & & & & \\ \text { Annual } & 4.5 & -1.0 & -4.0 & -5.0 & -6.0 \\ \text { Mean } & & & & & \end{array}$

Monthly Mean Precipitation ( $\mathrm{mm}$ )

$\begin{array}{lccccc} & \text { Juneau } & \text { Whitehorse } & \text { Mayo } & \text { Keno Hill } & \begin{array}{c}\text { Burwash } \\ \text { Landing }\end{array} \\ \text { January } & 94.2 & 21.6 & 17.5 & 41.5 & 5.0 \\ \text { February } & 91.2 & 12.1 & 16.4 & 54.0 & 17.8 \\ \text { March } & 80.0 & 15.4 & 10.3 & 35.5 & 14.9 \\ \text { April } & 71.6 & 12.2 & 8.6 & 28.8 & 12.8 \\ \text { May } & 88.1 & 11.1 & 19.5 & 21.9 & 31.6 \\ \text { June } & 73.9 & 33.9 & 35.3 & 59.0 & 51.5 \\ \text { July } & 106.7 & 33.6 & 51.7 & 55.9 & 32.6 \\ \text { August } & 129.5 & 35.2 & 41.5 & 76.7 & 51.4 \\ \text { September } & 159.8 & 25.1 & 30.3 & 51.3 & 34.3 \\ \text { October } & 188.7 & 17.5 & 28.3 & 61.9 & 22.0 \\ \text { November } & 128.3 & 23.6 & 24.4 & 46.0 & 7.5 \\ \text { December } & 109.0 & 20.4 & 22.5 & 57.7 & 2.7 \\ \text { Annual } & 1321.3 & 261.7 & 306.3 & 590.2 & 284.1 \\ \text { Mean } & & & & & \end{array}$

Sources: Data For Juneau Airport $\left(58^{\circ} 22^{\prime} \mathrm{N}, 134^{\circ} 35^{\prime} \mathrm{W}\right.$; elev. $\left.6 \mathrm{~m}\right)$. Data for Whitehorse Riverdale $\left(60^{\circ} 43^{\prime} \mathrm{N}, 135^{\circ} 01^{\prime} \mathrm{W}\right.$; elev. $\left.643 \mathrm{~m}\right)$. Data for Mayo Airport $\left(63^{\circ} 37^{\prime} \mathrm{N}, 135^{\circ} 52^{\prime} \mathrm{W}\right.$; elev. $\left.504 \mathrm{~m}\right)$. Data for Keno Hill $\left(63^{\circ} 56^{\prime} \mathrm{N}, 135^{\circ} 12^{\prime} \mathrm{W}\right.$; elev. $\left.1472 \mathrm{~m}\right)$ from (Burn, 1994). Data for Burwash Landing airstrip $\left(61^{\circ} 22^{\prime} \mathrm{N}, 139^{\circ} 02^{\prime} \mathrm{W}\right.$, elev. $\left.689 \mathrm{~m}\right)$ provided by Environment Canada ,1996 


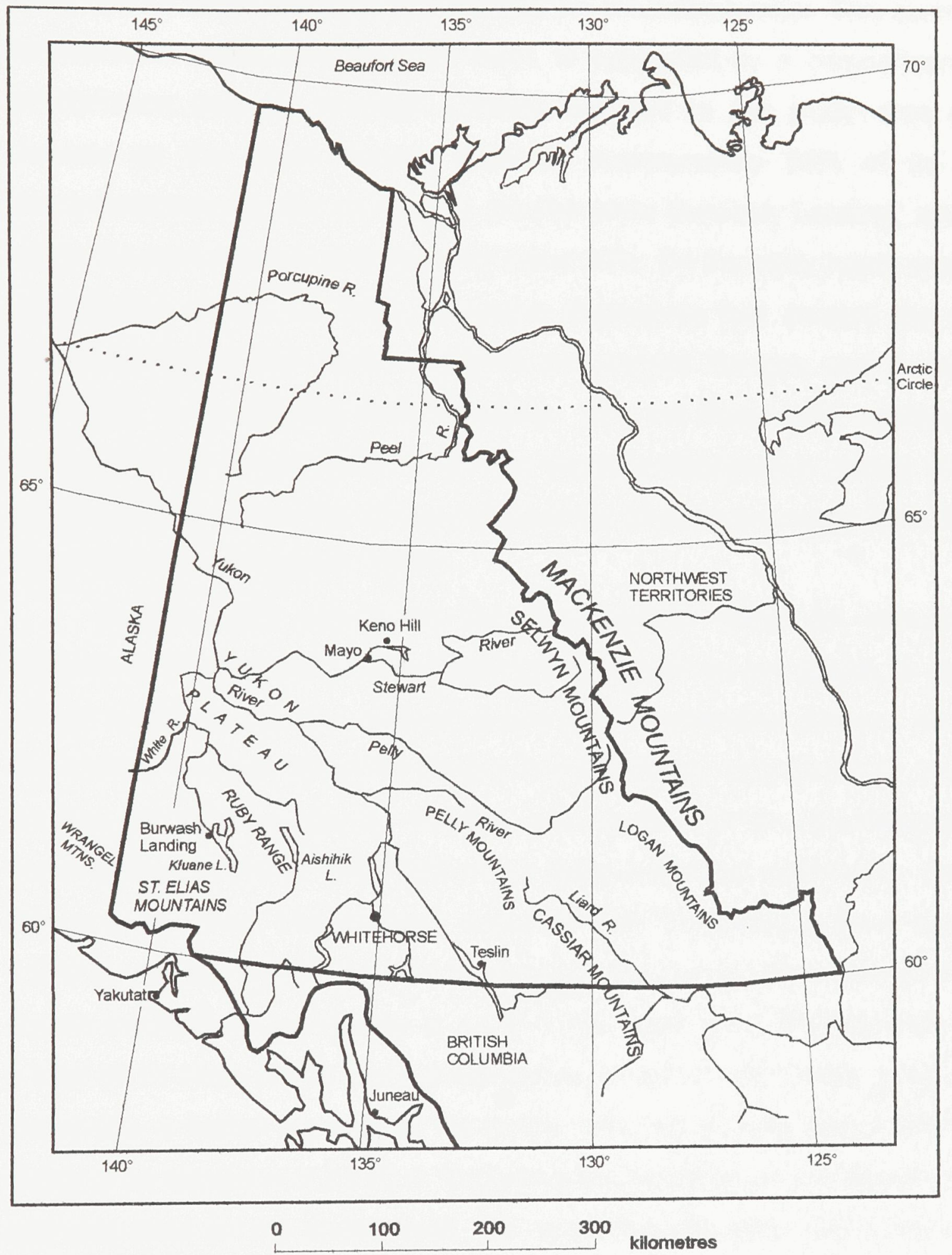

Map 2.1: Selected regional weather stations in the Yukon and Alaska. 
movements and by storms penetrating the region from the Bering and Beaufort Seas, but Burn (1994) maintains that winter precipitation is derived solely from the moisture which manages to penetrate the mountain barrier. This summertime amelioration effect, postulated by Burn, is supported by a comparison of the precipitation data for Burwash Landing adjacent to the study area and for Juneau on the coast. Juneau receives approximately $58 \%$ of its annual precipitation during the six coldest months while Burwash Landing, which lies within the rain shadow, receives only about $29 \%$. On the other hand, orographic precipitation on the St. Elias Mountains themselves has created the modern intermontane ice-field which straddles the lcefield Ranges and is the most extensive in continental North America. The ice flows both eastward and westward from around $2620 \mathrm{~m}$ on the Hubbard-Kaskawulsh glacial divide. A seismic profile across the divide indicates ice thicknesses range from $240 \mathrm{~m}$ to 670m (Denton and Stuiver, 1967).

Precise data concerning the rain shadow effect on annual snow accumulation within the St. Elias Mountains themselves are sparse. A literature review revealed only one detailed record of the distribution pattern. As part of the Icefield Ranges Research Project in the mid-60s, sponsored by the Arctic Institute of North America, Marcus and Ragle (1972) investigated snow accumulation in the St. Elias Mountains along a transect adjacent to the Ruby Range study area. The transect stretched from the lower Seward Glacier at 1,370 m elevation near the coast eastward to the vicinity of the transient snowline on the Kaskawulsh Glacier at 1,615 m elevation. In all, the researchers dug a total of 14 snow pits at various elevations, seven of which were sited west of the divide, a further six east of the divide, and one pit was established at the divide at an elevation of $2,620 \mathrm{~m}$. Excluding the lowest pit on the Seward Glacier and one sited on the divide itself, the remaining pits were distributed on two nearly symmetrical slope profiles. The average water-equivalent accumulation 
for 1964-1965 on the Seward Glacier sites was $1244 \mathrm{~mm}$, while the equivalent on the Kaskawulsh sites was only $684 \mathrm{~mm}$. This suggests that the orographic effect of the St. Elias Mountain barrier not only inhibits snowfall accumulation in the northwest Ruby Range, but also inhibits accumulation on at least one of the main eastward-flowing St. Elias glaciers. These eastward-flowing glaciers, collectively, are believed to have been major contributors of ice to the northwest Ruby Range during some, if not all, of the late Cenozoic glacial advances. This latter assertion, however, requires some qualification for although the average water-equivalent accumulation at the Kaskawulsh is only a little over half the equivalent accumulation on the other side of the divide, it is nonetheless more than twice the total average annual precipitation received at Burwash Landing on the westernmost fringe of the northwest Ruby Range study area.

\subsubsection{Regional Paleoclimate}

The present regional climate marks the current status of what appears to be a long-term cooling trend which began in Tertiary time. Citing earlier work on Tertiary fossil floras, Denton and Armstrong (1969) state that, in Alaska, the initial warm climate which prevailed at the beginning of the Tertiary underwent a slight cooling trend throughout the Paleocene. Later in northwestern North America, a major climatic deterioration occurred during the late Miocene in which the average July temperature fell $7^{\circ} \mathrm{C}$ within $4 \mathrm{M} . \mathrm{y}$. These findings are supported by oceanic oxygen isotope records, from which Molnar and England (1990) determined that a cooling trend, resulting in a drop of at least $10^{\circ} \mathrm{C}$, occurred during the Tertiary.

This climatic cooling trend had progressed sufficiently by Middle to late Miocene time for glaciation to commence in the St. Elias Mountains (Eisbacher and Hopkins, 1977). Evidence for this lies in the deposition of tillites inland (Denton and Armstrong, 1969), and the glaciomarine facies of the Yakataga 
formation in the Gulf of Alaska (Plafker and Addicott, 1976). There is some evidence to suggest that the cooling underwent a partial reversal in the Pliocene before it resumed in the early Quaternary. Mathews and Ovenden (1990), for instance, maintained glaciation was limited in Pliocene time as indicated by a well-dated temperate vegetation pollen record from Lost Chicken mine, eastcentral Alaska.

These findings have been confirmed by work done on a stratigraphic sequence of tills and tillites found in the White River Valley on the northeast flank of the Wrangell Mountains of southern Alaska (Denton and Armstrong, 1969). These strata were found to be interbedded with lavas for which potassium-argon dates could be determined. From these dates the authors conclude that intermittent glaciation has occurred during the last 10 M.y. in the northern Wrangell and St. Elias Mountains. A minimum of 16 major glacial expansions are recorded - twelve in tillite beds and four in tills. They hypothesize that many of these glaciations occurred around 9 to 10 M.y. ago, and that several may be even older. A subsequent advance may have occurred around 3.6 M.y. ago, and they indicate that at least two occurred between 8.8 and 2.7 M.y. ago. These sections underwent deformation after 2.7 M.y., and at least four major expansions occurred after that date, possibly even after 1.6 M.y. which, if true, would have made them Pleistocene in age.

The late Tertiary-Quaternary climate trend in the southern Yukon is believed to be similar to the southern Alaskan trend. Bostock (1966) maintained that at least four major Cordilleran glacial advances occurred in the Yukon during the late Pliocene and Pleistocene. The last two advances, in Illinoian and late Wisconsinan time, have been described as spatially and temporally well defined (Bostock, 1966; Mathews et al., 1990). In addition, Bostock (1966) and Hughes et al. (1969) documented three advances of continental ice in the eastern Yukon. According to Clague (1989), the Cordilleran and Laurentide 
advances during the last glaciation were broadly synchronous, although he conceded that there were "undoubtedly" some differences in timing. Paleomagnetic evidence from Fort Selkirk in the central Yukon indicates that the earliest and most extensive advance in that area occurred before $1.87 \mathrm{M} . \mathrm{y}$. (Jackson et al., 1990). Ward and Jackson (1992) postulated that the enhanced rain shadow from concurrent coastal mountain uplift progressively restricted the extent of subsequent glaciations.

The permafrost records for the region confirm that the late TertiaryQuaternary cooling trend, as revealed in the glacial records, continued into the late Pleistocene. Five well-developed paleosols in a stacked sequence on the Little Bear River in the MacKenzie Mountains, which have been attributed to interglacials up to Illinoian time, contain no cryogenic features (Hughes et al., 1993). The only evidence of pre-Illinoian permafrost is a possible ice-wedge cast from the Liard Lowland, southwestern Yukon, tentatively assigned to the Yarmouthian interglacial (0.55 M.y.) (Klassen, 1987). Pollen records indicate that climatic conditions prior to the Gauss Chron were too mild to permit the development of permafrost. (Mathews and Ovenden, 1990), and speleothems in north Yukon caves ascribed to the Gauss Chron (2.48-3.40 M.y.) indicate groundwater was uninhibited by permafrost (Lauriol et al., 1993). However, the lack of speleothem development in caves south of Old Crow during the period of magnetic reversal following the Gauss Chron (0.79-2.48 M.y.) indicates that groundwater circulation had been interrupted by permafrost. (Lauriol et al., 1993). 


\subsection{Regional LANDScape DeVELopment}

\subsubsection{The Yukon Plateau}

The available evidence indicates that the Yukon Plateau, of which the Ruby Range is a component, has undergone relatively modest alteration since the mid-Tertiary. Earlier geological maps indicate that the formations within the Ruby Range consist of mainly Pre-Mesozoic metamorphic rock of the Yukon Complex as well as igneous rock of the Ruby Range Batholith whose age was estimated to be Mesozoic and (?) Cenozoic (Muller, 1967, Map 1177A). Later KAr dating of these formations, as reported by Mortensen and Erdmer (1992), indicates that metamorphism and deformation in this area coincided with emplacement of the Paleocene-Eocene Ruby Range Batholith.

This revised dating, however, does not contradict the essentials of Templeman-Kluit's (1980) contention that the modern Yukon Plateau is the remnant of a Tertiary erosion surface that was leveled between 45 and 15 M.y., and that the rudiments of the present drainage network were defined by the end of the Miocene. He further speculated that Pleistocene ice emanating from the St. Elias Mountains may have blocked the Tertiary drainage from the Yukon Plateau into the Gulf of Alaska, reversed the flow, and created the present plateau drainage system. Pleistocene glacial erosion would also have increased the earlier plateau relief which Mathews (1989) describes as much less than present relief.

\subsubsection{The St. Elias Orogeny}

In contrast to the relatively modest alteration of the Yukon Plateau, the geological evidence indicates that, in mid-Tertiary time, the presently glaciated area of the central St. Elias Mountains (Icefield Ranges) was a mere upland 
region, dissected by rivers flowing both northeast and southwest. The present topographic contour interval between 2000 and $3000 \mathrm{~m}$ can probably be taken as an indication of the upper limit of mid-Tertiary fluvial deposition because, above this elevation, the Wrangell Lavas facies, dated between 16 M.y. and 6 M.y. by $\mathrm{K}-\mathrm{Ar}$, rests directly on bedrock with no intervening layer of fluvial deposits (Eisbacher and Hopkins, 1977). Further evidence that the area currently occupied by the St. Elias Mountains did not exist as a barrier to westerly drainage of the Yukon Plateau before mid-Tertiary time is found in the conglomerates of the early Tertiary Amphitheatre Formation. Crossbedding and sporadic pebble imbrication indicate westerly flowing paleocurrents (Eisbacher and Hopkins, 1977). Based on earlier work by Eynon and Walker (1974) and McGowen and Garner (1970), Eisbacher and Hopkins (1977) conclude that the coarseness of the clastics is characteristic of deposition in a strong meandering and braided channel system. In addition, they found that conglomerate of the Amphitheatre Formation from Cement Creek west of Amphitheatre Mountain contains biotite schists suggesting a source east of Shakwak Trench.

In addition to the evidence of drainage reversal, there is also direct evidence of concurrent uplift in the St. Elias Mountains. This uplift is believed to have been continuous since Late Oligocene time (30 M.y.), and relatively rapid (0.3 mm/yr on average) since 16 M.y. (Eisbacher and Hopkins, 1977; Parrish, 1981). That such rapid rates of uplift are plausible for Pacific Northwest is confirmed by Clague (1989) whose estimate for the uplift rate along the Queen Charlotte Fault during the Quaternary is at least $2.0 \mathrm{~mm} / \mathrm{yr}$, a rate which Mathews (1989) claimed would have been sufficient to have created the highest mountain range in Canada from its subdued configuration some 2 M.y. ago.

Based on dates derived through apatite fission tracks, Parrish (1981) concluded that the net uplift (uplift less denudation) of Mount Logan increased from approximately $0.1 \mathrm{~mm} / \mathrm{yr}$ to $0.3 \mathrm{~mm} / \mathrm{yr}$ around 13-16 M.y. ago. Based on 
tilting and deep incision of Pliocene and early Quaternary lavas along the Fraser River in British Columbia, Mathews (1989) suggests that the uplift in the Pacific Northwest has continued into the Quaternary. Parrish (1981) postulated that the uplift of the Logan massif probably continues at a current rate of approximately $0.35 \mathrm{~mm} / \mathrm{yr}$.

Other evidence of recent local uplifting includes the presence of poorlycemented granitic diamicton (Plate 2) on the summit of Amphitheatre Mountain (Map 1.2) at an elevation of $2012 \mathrm{~m}$. Eisbacher and Hopkins (1977) believed that the granitic clasts were derived from an outcrop to the northeast whose current surface lies at $1656 \mathrm{~m}$. They postulated that the clasts were transported to their current site by a massive southwestward debris flow indicating that local uplift has been of sufficient magnitude to actually reverse the original slope between the two sites. They noted that the diamicton lies conformably over Wrangell Lavas which, as stated earlier, have been dated at 16-6 M.y. by K-Ar dating. Further evidence of recent uplift activity in this vicinity is the presence of a Holocene scarp northeast of the Duke River with a 1 to $2 \mathrm{~m}$ displacement (Eisbacher and Hopkins, 1977).

\subsubsection{The Shakwak Trench}

Not only has the St. Elias orogeny had an effect on the distribution of precipitation and consequently on the distribution of ice during successive glaciations in the region, but the distribution of ice has also been altered by the concurrent development of the Shakwak Trench, a graben, which, due to its size, must have formed a significant ice sink by the Late Pleistocene for eastward flowing glaciers exiting the St. Elias Mountains. As it stands today, the Shakwak Trench, measured along its southwestern fault scarp, extends some $280 \mathrm{~km}$ in length. The scarp itself rises some $1000 \mathrm{~m}$ above the trench floor. Erosion has 




Plate2: Tertiary diamicton deposit on Amphitheatre Mountain 
caused the crest of the scarp to retreat some $500 \mathrm{~m}$ southwestward from the originating fault.

Development of the Shakwak Trench and the facts that the associated movements were not only of relatively recent origin, but continued into the Holocene was first hypothesized by Bostock (1969). He observed a lineament consisting largely of a line of mounds running along the southwestern edge of the Shakwak Valley from the Donjek River (where the lineament projects as a ridge) and continuing in a southeasterly direction past the Ruby Range study area. From the fact that these features had not completely eroded away, Bostock (1969) concluded that the fault movement which caused them had taken place in recent centuries.

The initiation of the movements associated with the creation of the graben have been estimated from the measured distance of the scarp crest retreat. Scarp retreat rates between 0.1 and $3 \mathrm{~mm} / \mathrm{yr}$ have been measured under a variety of conditions (Young, 1972; Bloom, 1978), and slope retreats of approximately $0.1 \mathrm{~mm} / \mathrm{yr}$ have been measured under Yukon-like climate regimes (Rapp, 1960). Based on the work by Young (1972) and Bloom (1978), Tempelman-Kluit (1980) estimated the age of the trench to be between 5 and 0.2 M.y., but argued that the older age is more likely in view of the rates observed by Rapp (1960). This would put the start of trench formation within the Late Miocene - early Pliocene time-frame.

\subsubsection{Alteration of Precipitation Distribution}

On balance, the evidence assembled above leads to the hypothesis that the St. Elias orogeny and the development of the Shakwak Trench may have profoundly altered the distribution of precipitation and consequently the accumulation of ice during successive glaciations commencing in mid-Tertiary time and continuing into the Holocene. The uplifting of the St. Elias Mountains 
would have had the effect of greatly increasing precipitation near the coast at the expense of precipitation on the Yukon Plateau. During the earliest glaciations before the orogeny, glacial ice probably accumulated on the Yukon Plateau and flowed outward from local domes in the manner of continental ice sheets. However, during subsequent glacials these interior uplands would have been starved of local precipitation, while at the same time the developing Icefield Ranges ice sheet to the west would have gradually emerged as the major source of glacial ice accumulation within the region.

Much of this newly accumulating ice would have flowed westward into the Gulf of Alaska. However, the rising drainage divide could conceivably have directed an increasing amount eastward towards Yukon Plateau. Under normal circumstances, this eastward-flowing ice could have overridden the plateau during the later glaciations. However, the concurrent development of the Shakwak Trench created an ice sink, which would absorb much of this flow, and consequently areas of the plateau, such as the Ruby Range, would have been penetrated by only limited volumes of ice in the form of valley glaciers during the more recent glacials.

This hypothesis, however, is not entirely problem-free. It is based on an assumption that the bulk of precipitation distributed throughout the Pacific Northwest is carried by prevailing westerlies. Work by some researchers has indicated that atmospheric circulation can be altered during glacials. (Selby, 1985), and Boulton (1982), for instance, in setting out hypotheses for major ice fluctuations in the northern hemisphere according to a minimum model, postulated that high-pressure systems in the Arctic blocked out moist air masses at higher latitudes in two of the three stadials of the Last (Wisconsinan) Glaciation. However, with respect to the glaciation of the Yukon Plateau, the belief that the St. Elias rain shadow has exercised a controlling influence (Ruddiman et al., 1988; Ruddiman and Kutzbach, 1989; Kutzbach et al., 1989; 
Eisbacher and Hopkins, 1977; and Burn, 1994) appears to be the current consensus viewpoint. The rain-shadow hypothesis provides a reasonably convincing explanation for decreasing local ice formation on the Yukon Plateau during successive glacials over long periods of time, and the concurrent development of a major drainage divide in the Icefield Ranges raises the possibility of increasing eastward ice flows from the new accumulation area.

\subsection{GLACIATION}

\subsubsection{Introduction}

This section reviews the literature on the paleoglacial history of the region and the attempts to correlate local glacial sequences to regional and continental glacial chronologies. The glacial chronologies proposed by J.E. Muller for the Kluane Lake Map Area, based on surface morphology, and by G. S. Denton for the Shakwak Valley, based on drift stratigraphy, are discussed in detail. Subsequent attempts to correlate these chronologies to the regional and North American Pleistocene succession are also examined.

\subsubsection{General Interpretation Difficulties}

Major difficulties inherent in interpreting the glacial history of the Ruby Range are acknowledged by Muller whose original work, (Muller 1967), forms the starting point for this study. In a review of this work in Hughes et al. (1969), he subsequently acknowledged that depositional features marking the limits of the ice sheets in Ruby and Nisling Ranges were poorly preserved or lacking on steep, open hillsides, rendering the delineation of glacial limits much more difficult than in areas further to the east, and that the problem was further 
complicated by the presence of ice-marginal features of local Pleistocene ice caps and valley glaciers.

Other difficulties are discussed in some detail by Johnson and Kodybka (1984) who postulated that Pleistocene glaciations in the Ruby Range extended from almost complete glaciation in the early stages to almost complete deglaciation by the beginning of the Holocene. In the early Pleistocene, the Ruby Range was, according to these authors, overridden by a confluence of ice flows. Under conditions of complete regional ice cover, such as those which are believed to have prevailed in the earlier glaciations, local direction of flow would have been complicated by the confluence of three separate ice streams: one of eastward flowing ice from adjacent valleys in the St. Elias Mountains, another of westward flowing ice of inland origin, and a third of northward flowing ice originating in the more southerly sections of the St. Elias Mountains, the last having been deflected from its original easterly course upon encountering westward-flowing inland ice.

To further complicate flow patterns, the northward glaciation limit lies just to the north of the Ruby Range, leading Johnson and Kodybka (1984) to speculate that the ice cover over the more northerly section of the Ruby Range could not have been very thick, even during the earliest glacials, and as a result of this, its flow patterns would probably have been altered by local topography. They further imply that modeling of ice flow using a gradient approach would have been unreliable in any case because the physical and chemical attributes of the Pleistocene ice are unknown. Earlier work by Koerner and Fisher (1979) on the Devon Island ice cap indicated that these properties could be significant.

A considerable body of evidence exists to suggest that complete regional ice cover of the earliest glaciations was supplanted by topographically limited valley glaciers during subsequent glacial events. This further complicates interpretive efforts. North of Gladstone Creek, for instance, Johnson and 
Kodybka (1984)00 found that cirques had developed during more recent glacials, but they could find no evidence that local ice caps also developed at the same time. They also speculate that terminal moraines from down-valley extensions of these cirques may have been synchronous with the late stages of regional ice expansion into the lower valleys which potentially creates a source for confusion, and may have obliterated earlier glacial deposits.

Johnson and Kodybka (1984) also suggested that tor weathering, an often relied-upon indicator of relative age, can be misleading in the Ruby Range. They postulated that, during deglaciation, the plateau surface would have become ice-free before the adjacent valleys. This would have resulted in differential weathering in which tors could have evolved on the plateau surfaces while the valleys in the same area were still glaciated. Subsequent alteration of moraines makes the demarcation of penetration limits difficult which further complicates the interpreter's task (Johnson and Kodybka, 1984).

Much of the work of glacial correlation in the region has used the presence, relative abundance, or absence of granitic erratics as a major indicator of glacial flow (Wahrhaftig, 1958; Muller, 1967; Rampton, 1981). However, Johnson and Kodybka (1984) argued that the presence or absence of erratics as a criterion for glaciation is unreliable because subsequent general weathering and periglacial activity may have altered or destroyed much of the evidence.

Another major difficulty in interpreting the glacial history of the region stems from the scarcity of datable material. Very little suitable material for ${ }^{14} \mathrm{C}$ dating has been found in Ruby Range deposits. Johnson and Kodybka (1984) argued that this scarcity, together with the observed non-conformity of glacial events from valley to valley, render the few dates available extremely suspect for reconstruction purposes. Similarly, they also state that lichenometry has severe limitations in the Ruby Range environment due to: lack of suitable type growth 
curves, the variability of alpine climatic conditions, and a high probability of disturbance of glacial deposits in the post-depositional period. They also found that there are only two reliable stratigraphic marker horizons, both of which consist of Holocene volcanic ash deposits and, hence, offer no prospect of longterm dating (Johnson and Kodybka, 1984).

\subsubsection{Regional Glacial Sequences}

Despite all these difficulties, it has been established from somewhat fragmentary but nevertheless convincing evidence that there have been a number of glacial advances in the region, from at least mid-Tertiary time (Denton and Armstrong, 1969; Eisbacher and Hopkins, 1977; Plafker and Addicott, 1976). Early field observations by Wahrhaftig (1958) of glacial deposits in the Nenana River region of Alaska identified only three glacial advances: the Browne (earliest), the Healy (intermediate), and the Riley Creek (most recent).

Based on observations in the central Yukon, Bostock (1966) identified two clearly defined series of glacial limits which, he felt, were readily correlated and traceable from place to place. The youngest of these, which he named the McConnell glacial limit, is marked by fresh ice-marginal landforms. The second, a well-marked zone of ice-marginal landforms forming a distinctly older glacial limit, he named the Reid glacial limit. In addition, he noted the presence of yet older modified glacial landforms to which he applied the term, Klaza Drift. He applied the term, Nansen Drift, to a series of deeply weathered deposits without glacial topographic features which he believed were even older than the Klaza deposits. Bostock's map indicates that the Reid glacial limits lay north and west of the younger McConnell limits, and that the Klaza Drift deposits lay to the west of the younger Reid glacial limits. The oldest Nansen Drift deposits occupy a broad arc northwest and west of both the Reid glacial limits and the Klaza Drift deposits. The arcuate shape of their limits indicates a northwesterly ice flow. 
Meltwater channels correlated to each of these advances confirm a general northwesterly flow for all three glacial events.

\subsubsection{Muller's Glacial Sequence}

\subsubsection{General}

Muller (1967) provided the first detailed study of the glacial history of the Kluane Lake Map Area, which includes the northwest Ruby Range, based on reconnaissance and geological mapping conducted in the years 1950-53, and 1957. His study builds on earlier descriptive works on the geomorphology of the St. Elias Mountains and the northwest Shakwak Trench by Bostock (1948, 1952). Muller's (1967) glacial history of the region was based on aerial photography and reconnaissance bedrock mapping. Specifically he determined the edge of former valley glaciers primarily through the identification of their scouring limits (schliffgrenzen). These he found to be clearly visible both on the ground and on air photographs. He was also able to directly identify glacial limits in some instances through the presence of both lateral and end moraines. Additionally, he sometimes used the highest of a group of channels or notches as a close approximation of maximum ice level.

On the plateau areas, Muller (1967) hypothesized that the edges of former nunataks could be identified through their distinctive shoulders. He argued that even if the hill slopes had subsequently undergone stream erosion, an abrupt change of slope in the remaining spurs might still indicate the former ice-margin. In a few cases, it was necessary to determine ice limits inferentially from ice-limits in adjacent valleys. He proposed that the correlation of observable glacial limits into systems of ice-fields and glaciers was possible only by assuming at least three progressively less extensive ice-sheets, each terminating in numerous valley glaciers, and when this hypothesis was applied, 
he observed that the upper limit of each younger ice-sheet would be 300 to 450 meters below that of the preceding glacial maximum ice surface elevation (Muller, 1967).

\subsubsection{Nisling Ice Sheet}

The uppermost level of glacial erosion was attributed to the passage of the Nisling ice-sheet, and, according to Muller, determination of the separate identity and extent of these Nisling surfaces were based on traces of glaciation above the level and beyond the extent of the relatively well-marked Ruby icesheet (Muller, 1967). Within the Nisling zone, residual erratic material ranging in size from small pebbles to large boulders was found to be scattered on many plateau surfaces (Muller, 1967). Although he accepted the presence of erratics, marginal channels, and notches as the only unmistakable topographic evidence for glaciation to this extent, he also took the presence of broad, flat-domed hills, albeit with castellated outcrops in places, as further evidence that these were surfaces of Nisling origin. He also interpreted several plateau top surfaces separated from the surrounding highland surfaces by sharp breaks in slope as probable Nisling nunatak areas.

Muller (1967) determined that during the Nisling maximum, the average ice surface elevation was about 1,825 meters over the northeastern St. Elias Mountains and 1525 meters over the Yukon Plateau. However, for the terrain within the boundaries of the current study area of the Ruby Range, his map $(1178 \mathrm{~A})$ indicates that Nisling maximum upper ice contact limit occurs at about 1890 meters. Based on the trends of major ice channels and of the distribution of nunatak areas, Muller postulated that the main movement of Nisling ice was possibly northwest, except in the higher portions of the St. Elias Mountains (Muller, 1967). 


\subsubsection{Ruby Ice Sheet}

In contrast to Nisling surfaces, Muller (1967) found that the Ruby icesheet had left good ice-limit features, such as terminal moraines, kame terraces, and well-developed marginal meltwater channels, in relative abundance. Rock drumlins and large-scale grooves were visible on aerial photographs in upland areas, but many of the valley-bottom morainal features were found to have been smoothed by subsequent lacustrine development. Unlike its Nisling predecessor, the Ruby ice was much more confined by valley walls, but many of the older upland surfaces had been incised by Ruby period glacial valleys and cirques. Muller believed that the Ruby glaciers originated in the Ruby Range uplands as well as in the Kluane Ranges, although apart from cirque sites, evidence of local Ruby Range ice sources contemporaneous with Ruby glaciation was not presented. He assigned only those cirque sites displaying well-defined moraine features, craggy walls and tarns to the Ruby period (Muller, 1967).

Based on remnants of lateral moraines and the transition from rough (Nisling) to polished (Ruby) valley walls, Muller (1967) noted that, in general, Ruby ice surfaces reached maximum elevations approximately 150 to 300 meters below comparable Nisling ice surfaces, i.e. at elevations of between 1740 and $1590 \mathrm{~m}$. However, within the bounds of the current study area, his map indicates a somewhat greater differential, with the Ruby/Nisling boundary occurring generally at around 1430 meters. Muller found the general level of small Ruby cirques on the northeast faces of the Ruby Range to lie at the $1670 \mathrm{~m}$ contour and to be slightly higher on southwest faces (Muller, 1967).

Muller (1967) believed that the Shakwak Trench, which lies immediately southwest of the current study area, contained a major Ruby period ice-field with the maximum ice surface reaching 1525 meters in the southeast and descending to below 1200 meters in the northwest. This ice surface gradient suggests a northwestward ice flow within the trench with augmentation from glacial ice 
discharges through the major valleys draining the St. Elias Mountains. Within the Ruby Range itself, he postulated that inflow from the Shakwak Trench was augmented by ice generated in "local centers." However, as previously noted, apart from the presence of Ruby age cirque basins, evidence of local ice accumulation was not presented (Muller, 1967).

\subsubsection{St. Elias Glacial Advance}

Although Muller found evidence of modern local glacial advances southwest of the Shakwak Trench, to which he applied the designation, "SubRecent Advances," the most recent glacial advance to have occurred within the geographic limits of the current study area pre-dates the Holocene and was named the "St. Elias Glacial Advance." Muller typified the terrain occupied during the St. Elias glacial advance as being associated with sharp cirques with a very fresh appearance and with well-defined end moraines (Muller, 1967).

Within the current study area, his map indicates only one St. Elias ice lobe which advanced up the Jarvis River valley from the southeast with one sublobe penetrating northward into the Fourth of July Creek valley and the main lobe advancing northwestward to a readily identifiable terminal moraine at the Jarvis River/Cultus Creek drainage divide. The map also indicates that the maximum upper ice contact limit for this lobe within the current study area was around 1430 meters which coincides with the average maximum upper ice contact limit for that portion of the Ruby ice-sheet which lay within the current study area (Muller, 1967, Map 1178 A).

\subsubsection{Correlation to Other Regional Glacial Sequences}

Muller (1967) observed the abundance of very large granitic erratics on Nisling surfaces and noted that in the Central Alaska Range, Wahrhaftig (1958) 
also found that the Browne glaciation was solely represented by large, mainly granitic erratics. Based on this observation, Muller (1967) postulated that the Nisling ice-sheet and the Browne glacial were contemporaneous.

Muller (1967) further correlated the subsequent Ruby glaciation to Wahrhaftig's Healy glaciation based on the description of Healy deposits. Wahrhaftig (1958) described these deposits as the most extensive of the Nenana region glaciations and characterized by fairly well-preserved but considerably smoothed out morainal deposits, a description which Muller felt could be equally applied to comparable Ruby deposits. Muller (1967) further speculated that the Reid glaciation recognized in many parts of the Yukon Territory and British Columbia is probably also correlative to the Ruby ice-sheet (Muller, 1967).

Muller (1967) further correlated his St. Elias Glacial Advance to Wahrhaftig's Riley Creek glaciation on the basis that the latter was the last extensive glaciation in the Nenana region reported by Wahrhaftig (1958) and, like the St. Elias, shows a fresh moraine topography. Additionally, in an examination of a section of glacial deposits in a gully north of Wolverine Creek, a tributary of the upper Donjek River, Muller (1967) found two tills of similar degrees of weathering separated by glacial fluvial deposits. He speculated that the two tills probably represent two stages of the same glaciation, and that the lower till is of Ruby ice-sheet origin while the upper till bed is from the St. Elias glacial advance (Muller, 1967).

Muller also speculated that the St. Elias glacial advance may have coincided with the last advance of the Russell Glacier, the source of the White River. Using radiocarbon dating, he was able to confirm earlier work by Capps (1915) on a 12-meter peat exposure overlying unconsolidated and unoxidized boulder till in a cutbank of the White River which indicated at least an 8,000 year age for this till (Muller, 1967). 
A summary of the various northern Cordilleran glacial sequences is presented in Table 2.2.

Table 2.2: Various Northern Cordilleran Glacial Sequences

\begin{tabular}{|c|c|c|c|}
\hline Wahrhaftig (1958) & Bostock (1966) & Muller (1967) & Denton and Stuiver \\
\hline $\begin{array}{l}\text { Central Alaska } \\
\text { 1. Browne } \\
\text { 2. Healy } \\
\text { 3. Riley Creek }\end{array}$ & $\begin{array}{l}\text { Central Yukon } \\
\text { 1. Nansen } \\
\text { 2. Klaza } \\
\text { 3. Reid } \\
\text { 4. McConnell }\end{array}$ & $\begin{array}{l}\text { Southwest Yukon } \\
\text { 1. Nisling } \\
\text { 2. Ruby } \\
\text { 3. St. Elias } \\
\text { 4. Sub-Recent }\end{array}$ & $\begin{array}{l}\text { Southwest Yukon } \\
\text { 1. Shakwak } \\
\text { 2. Icefield } \\
\text { 3. Kluane } \\
\text { 4. Neoglaciation }\end{array}$ \\
\hline
\end{tabular}

\subsubsection{Correlation to the North American Pleistocene Succession}

Muller (1967) maintained that any attempt at correlation with the North American Pleistocene succession was hardly warranted. However, since Wahrhaftig (1958) had suggested that the Browne glaciation was pre-Wisconsinan, possibly Kansan or Nebraskan, Muller (1967) concluded that a pre-Wisconsinan age was also most likely for the Nisling ice-sheet. He further concluded that since a radiocarbon date of $10,560 \pm 200$ years for the Riley Creek glaciation reported by Wahrhaftig (1958) indicated late Wisconsinan age, a late Wisconsin age was conceivable also for the St. Elias advance (Muller, 1967). As to the correlation of his Ruby glaciation to North American Pleistocene succession, Muller (1967) concluded that the age of the Ruby ice-sheet, intermediate between Nisling ice-sheet and St. Elias advance, may be early Wisconsin (lowan?). He felt that a pre-Wisconsin age was less likely in view of the state of topographic preservation (Muller, 1967).

\subsubsection{Subsequent Revisions}

In 1969, Muller joined with Hughes, Campbell, and Wheeler in publishing a paper in which they reviewed the evidence reported by previous researchers (principally Bostock, Denton, and Muller himself) of successive advances of the Cordilleran ice sheets in the Yukon interior and proposed an overall correlation 
of Pleistocene glaciation for the region (Hughes et al. ,1969). In attempting this regional correlation, they adopted Bostock's chronology and nomenclature of a late Wisconsinan McConnell advance, an early Wisconsinan Reid advance and indications of one or more advances (Klaza and Nansen) older than and more extensive than the Reid (Hughes et al., 1969).

Hughes et al. (1969) postulated that during the McConnnell advance, two non-synchronous lobes formed: one from a source in the Selwyn and northern Logan Mountains, and the other from a source in the Cassiar Mountains, and that these two lobes were separated by the physiographic barrier of the Pelly Mountains (Map 2.1). Their evidence suggests that ice from the Selwyn lobe penetrated westward into the north-central Aishihik Lake map area, approximately $80 \mathrm{~km}$ northeast of the Ruby Range study area, and that ice from the Cassiar lobe advanced westward and northwestward across the Whitehorse and Teslin map areas approximately $200 \mathrm{~km}$ southeast of the current study area (Map2.1). They present no evidence to suggest that ice from either of these two lobes penetrated the my study area or influenced the flow of ice from other sources into it.

Hughes et al. (1969) attempted to correlate easterly-flowing glacial advances emanating from the St. Elias Mountains to Bostock's (1966) chronology for the central Yukon. They also suggested that the Nisling advance was "probably correlative with the Reid" (early Wisconsinan). In his original paper Muller (1967) stated that the Nisling may have pre-dated the Wisconsinan and was contemporaneous with the Browne glacial advance.

Hughes et al. (1969) also revised the original correlation of the Ruby advance to place it contemporaneous to the McConnell (late Wisconsinan) as opposed to the earlier correlation of Muller (1967). They also claimed that the Ruby advance covered essentially the same region as the Nisling but was slightly less extensive. Their reasons for considering the Ruby advance to be 
only slightly less extensive are unclear and appear to be at variance with his own mapping. Muller's (1967) Map 1178A indicates that the Nisling ice took the form of an ice-field with few protruding nunataks, whereas the Ruby ice took the form of valley glaciers. Furthermore, the geometry of the glacial scouring in both cases suggest that the maximum thickness of both ice bodies was probably roughly the same. This combination of greater areal coverage by Nisling ice but comparable maximum thicknesses of both ice bodies suggest that Nisling ice volumes may have exceeded Ruby ice volumes by as much as a factor of two in the northwest Ruby Range according to my calculations.

Muller also postulated in Hughes et al. (1969), that although the main Ruby ice flow into the Ruby Ranges emanated from the St. Elias Mountains, the Ruby Ranges also sustained small independent ice caps above 1977 m from which ice tongues flowed down valley. Johnson and Kodybka (1984) subsequently investigated this claim, and, apart from encountering some fairly weathered cirque basins, could find no evidence to support the existence of small independent ice caps in Ruby time.

The difficulties with this attempt to correlate Muller's (1967) local sequence to Bostock's (1966) regional sequence become apparent in the handling of the St. Elias glacial advance. In Hughes et al. (1969), Muller maintained his original position outlined in 1967, that this was indeed a separate advance, but noted that the other writers of Hughes et al. (1969) report did not consider the St. Elias glacial advance features as indicative of a separate advance but regarded them as products in the retreat of the McConnell (Ruby) ice sheet, possibly of rather long duration to allow for the establishment of trough valleys.

A summary of the attempts to correlate events in Muller's (1967) glacial sequence to northern Cordilleran and continental sequences is presented in Table 2.3. 
Table 2.3: Correlations to Cordilleran and Continental Sequences

\begin{tabular}{|c|c|c|}
\hline Muller's Sequence & Cordilleran Correlations & Continental Correlations \\
\hline 1. Nisling & $\begin{array}{l}\text { a. Browne (1967) } \\
\text { b. McConnell }(1969)\end{array}$ & $\begin{array}{l}\text { a. pre-Wisconsinan }(1967)^{\star} \\
\text { b. early-Wisconsinan }(1969)\end{array}$ \\
\hline 2. Ruby & $\begin{array}{l}\text { a. Reid (1967)* } \\
\text { b.McConnell (1969) ** }\end{array}$ & $\begin{array}{l}\text { a. early or pre-Wisconsinan }(1967) * \\
\text { b. Iate-Wisconsinan }(1969))^{\star \star}\end{array}$ \\
\hline 3. St. Elias & a. Riley Creek (1967) * & a: late-Wisconsinan (1967) * \\
\hline 4. Sub-Recent & nil & nil \\
\hline
\end{tabular}

The greatest weakness in all these correlation attempts is that these earlier researchers appear to have relied very heavily on the relative "freshness" in the appearance of the walls of valley troughs. As a result of post-glacial erosion, the initial over-steepening by glacial scouring of valley walls tends to break down giving a less "fresh" appearance to the scouring with time. However, differences in petrology can profoundly alter the perception of "freshness", and especially when one relies heavily on aerial photography, as Muller was forced to do, both wetness and orientation with respect to the sun can also radically alter perceptions of "freshness." This points out the general weakness of the process of determining the relative age of glacial valley cutting by the "freshness" in appearance of the scouring of the valley walls, and yet "freshness" appears to have been the principal criterion in many of these early correlation attempts.

\subsubsection{Denton's Glacial Sequence}

\subsubsection{General}

Muller's (1967) study of the glacial history of the Ruby Range in the late fifties was followed in the mid-sixties by a study by $G$. H. Denton in that portion of the Shakwak Trench adjacent to the current study area. Whereas Muller had 

scouring on valley walls and upland surfaces, Denton (Denton and Stuiver, 1967) examined the stratigraphy of drift sequences at creek-bank cuttings in the Shakwak Trench along Outpost, Silver, Boutellier and Christmas Creeks. All of Denton's sites are approximately $20 \mathrm{~km}$ due south of the southern boundary of the current study area and lie across the path of ice which had flowed into the Shakwak Trench from sources within the St. Elias Mountains.

As reported in Denton and Stuiver (1967), Denton identified four groups of drift bodies, each representing a separate glacial advance. Projections of ice lobe limits suggest that each successive advance out of the St. Elias Mountains was more extensive than its predecessor. He designated the oldest advance as the "Shakwak", followed by the "Icefield", then the "Kluane", followed by the most recent, the "Neoglaciation". He based this grouping primarily on marker horizons consisting of two weathering zones and a soil within a stratigraphic sequence. Secondarily, he used ${ }^{14} \mathrm{C}$ dates, characteristics of contacts between units, and drift morphology. Individual drift sheets were differentiated on the basis of the following criteria: 1) contacts between separate drift sheets are sharply defined; 2) the internal contacts between units of the same drift sheet are gradational or interfinger; and 3) units are considered to belong to the same drift sheet when evidence of substantial intervals between the times of deposition of the units is lacking.

\subsubsection{Shakwak Glaciation}

As reported in Denton and Stuiver (1967), Denton characterized the Shakwak drift as the oldest and stratigraphically the lowest drift sheet recognized in his study area. Till fabric analyses indicated trends ranging from $\mathrm{N} 40^{\circ} \mathrm{E}$ to $\mathrm{N} 50^{\circ} \mathrm{W}$. They considered the Shakwak drift that Denton found to have been deposited by a valley glacier which flowed through the Slims River valley 
and extended at least $35 \mathrm{~km}$ northeast of the present terminus of the Kaskawulsh glacier; i.e., as far as the entrance to the Shakwak Trench. They speculated that similar advances probably occurred in all major valleys drained ice from the Icefield Ranges.

\subsubsection{Icefield Glaciation}

Icefield Drift is identified by its stratigraphical position between, and sharp contacts with, the overlying Kluane and the underlying Shakwak Drift deposits. The Icefield Drift is composed of units of outwash, till and lacustrine deposits. Denton and Stuiver (1967) speculated that the lacustrine deposits were laid down in a lake dammed by ice that flowed eastward from the Slims River valley across the Shakwak Valley and impinged against the Kluane Hills to the south of the current study area. The coloration of these drift deposits suggests that Icefield Drift is less oxidized than comparable units of Shakwak Drift. Till fabric analyses indicated trends ranging from $\mathrm{N} 40^{\circ} \mathrm{E}$ to $\mathrm{N} 90^{\circ} \mathrm{E}$. From known deposits of Icefield Drift, they determined that the minimum extent of the glacial tongue was $45 \mathrm{~km}$ from the present terminus of the Kaskawulsh Glacier. Denton also suggested that it is unlikely that an advance of this magnitude occurred in Slims River valley without occurring also in other valleys that drained the Icefield Ranges (Denton and Stuiver, 1967).

According to Hughes, in Hughes et al., (1969), the till fabric trends reported by Denton and Stuiver (1967), indicate that during the Icefield glaciation, ice flowing down the Slims River bulged into the Shakwak Trench and impinged against the Kluane Hills to the northeast. Hughes observed that the pattern differed from that of the general northwestward flow in the subsequent McConnell (Kluane) advance, and suggested that an independent piedmont lobe had developed during the Icefield glaciation that was less extensive than that which followed. It should be noted that Denton and Stuiver (1967) had reached a 
similar conclusion concerning the still earlier Shakwak glaciation which they believed was even less extensive than the subsequent Icefield glaciation and had not advanced beyond the entrance to the Shakwak Trench.

\subsubsection{Kluane Glaciation}

Known exposures of Kluane Drift overlie Icefield Drift and are covered only with a thin layer of Neoglacial loess, Neoglacial end-moraine sediments, and glacier ice. The surface morphology of Neoglacial features was described as well preserved by Denton and Stuiver (1967). Following up on their work, Rampton (1981, Fig. 45) indicated that in addition to a Slims River valley lobe, two other ice lobes exited the Kluane Ranges approximately $35 \mathrm{~km}$ southeast of Kluane Lake. These two lobes converged shortly exiting and jointly advanced in a northeasterly direction within the Shakwak Trench. Topographical controls may have channeled a portion of the combined lobes to the headwaters of the Jarvis River at the southeastern end of the study area. This body of ice may have been the same ice which Muller identified as the lobe which penetrated the current study area from the southeast during the St. Elias glacial advance (Muller, 1967, Map 1178A).

Till fabric analysis of Denton's drift exposures indicated trends in Kluane Till units ranging from $\mathrm{N} 30^{\circ} \mathrm{E}$ to $\mathrm{N} 70^{\circ} \mathrm{E}$ (Denton and Stuiver, 1967). Air photo analysis confirmed that glacial flow directly from the Icefield Ranges and indirectly through tributary glaciers in the Kluane Ranges flowed northward into the Shakwak Trench. From this, Denton (Denton and Stuiver, 1967) concluded that ice in the southeast Shakwak Trench continued to flow north and northeast, but elsewhere it flowed northwest along the valley, mostly confined by the Ruby Range on the east and the Kluane Ranges on the southwest. He also found that some ice escaped north through valleys transecting the Ruby Range. 
Denton and Stuiver (1967) ascribed all visible glacial erosion on the southwest wall of the Shakwak Trench to the Kluane glacial. This suggests that all pre-Kluane scouring along the southwest wall has been erased, which in turn implies that the earlier ice surfaces in this part of the valley were no higher than the Kluane maximum ice surface, and were perhaps even lower. This suggests that over the temporal span of the series of glacial events which have left visible evidence of their presence, the quantity of ice discharging eastward from the St. Elias Mountains into the Shakwak Trench had increased.

\subsubsection{Neoglaciation}

The Neoglacial was first defined by Sharp (1960) as a short convenient designation for a re-advance of ice subsequent to shrinkage during the Hypsithermal interval. Borns and Goldthwait (1966) equated the Neoglacial to the "Little Ice Age" as defined in Matthes (1939). Neoglacial drift was described by Denton (Denton and Stuiver, 1967) as consisting of fresh terminal moraine sediments surrounding the northeastern flank of the St. Elias Mountains.

Denton and Stuiver (1967) found evidence that the early Neoglacial advance began about 2640 years ago in the vicinity of the Kaskawulsh Glacier. A second period of expansion was identified as having occurred between 1250 and 1050 years ago (Denton and Karlén, 1973) with a third period of "major activity" beginning about 450 years ago and continuing until the present. From the description, the Neoglaciation appears to correlate with Muller's "Sub-Recent Advances" (Muller, 1967, Map 1178A), but no such Sub-Recent features have been identified within the current study area.

\subsubsection{Dating Denton's Glacial Sequence}

Based on earlier work by Denton and Stuiver (1967), Denton and Karlén (1973), and Rampton (1971), Rampton (1981, Fig. 17) drew up a Quaternary 
chronology of glacial and non-glacial events for Kluane National Park which lies adjacent to the west side of the Shakwak Trench. In it, he dated Denton's Neoglaciation after 2800 B.P., the Slims non-glacial interval after 12,500 yrs B.P., and ascribed both events to the "Postglacial" period. Next he dated Denton's (Denton and Stuiver, 1967) Kluane glaciation after approximately 29,500 yrs B.P. and groups this event along with the Boutillier "non-glacial interval" and the preceding Icefield glaciation as a sequence of events within the timespan of the Wisconsinan. He placed both the Silver non-glacial interval and the preceding Shakwak glaciation before approximately 100,000 yrs B.P. which he considered to be the late/middle Pleistocene boundary.

The basis on which Rampton assigned pre-100,000 B.P. dating to the Shakwak and Silver events is unclear. A reading of Denton and Stuiver (1967, Fig. 11 and Table 1) indicates that ${ }^{14} \mathrm{C}$-bearing materials within both Icefield and Shakwak drift were both found to exceed the technical limits for radiocarbon dating (49,000 years). Denton (1974) maintained that it was unclear to him whether the Icefield Glaciation is early Wisconsinan or Illinoian in age. A summary of onset dates which have been proposed for the key events of the Pleistocene chronology of the northeastern St. Elias Mountains (Kluane National Park) is given in Table 2.4.

Table 2.4: Approximate Onset Dates (yrs. B.P.) for Key Events Sources: Denton and Stuiver, 1967, Fig. 11; Rampton, 1981, Fig. 17

\begin{tabular}{ccc} 
Event & Denton and Stuiver & Rampton \\
\hline Shakwak Stadial & $>49,000$ & \\
Silver Interstadial & $>49,000$ & \\
Icefield Stadial & $>49,000$ & \\
Boutellier Interstadial & $37,700+1500$ to -1300 & \\
Kluane Stadial & $<30,100 \pm 600$ & $\sim 29,500$ \\
Slims Interstadial & $12,500 \pm 200$ & 12,500 \\
Neoglacial Re-advance & $2,640 \pm 80$ & 2,800
\end{tabular}




\subsection{CONCLUSIONS}

The foregoing indicates the difficulties with which earlier investigators struggled to establish paleoglacial chronologies for the Kluane Lake Map Area and their attempts to correlate these chronologies with regional and continental sequences. The weakness of the evidence results from the rather limited number of good exposures suitable for analysis and the lack of material suitable for absolute dating, facts which have been attested to by Johnson and Kodybka (1983), Denton and Stuiver (1967), and Muller (1967). In fact, the earliest absolute date that has been established for any glacial event in the region around Kluane Lake is the date given by Denton and Stuiver (1967) for the onset of the Boutellier Interstadial at 37,700 yrs B.P. (Table 2.4). All other evidence of earlier events is based on subjective observations such as the relative "freshness" of glacial scouring and the state of preservation of ice-contact features. In a similar vein, attempts at correlation to regional and continental chronologies rely on such ambiguous evidence as similarity of topographical preservation, degree of "polish", and the equally questionable criteria of the relative abundance of granitic erratics. In light of the limitations of these past studies, re-examination of all the currently published glacial chronologies for the region is justified.

Muller's (1967) mapping indicates a pattern of three successive glacial advances within the current study area each of which appears to have been less extensive than its predecessor. Denton and Stuiver's (1967) work indicates that three successive glacial advances exited eastward from the St. Elias Mountains, each of which extended further than its predecessor. This pattern of progressively diminishing advances in the northwest Ruby Range matched by progressively extended advances out of the St. Elias Mountains is consistent with changes in the regional distribution of precipitation which could have been 
brought about by an increasing rain shadow effect resulting from the orogenic uplifting of the St. Elias Mountains which has been in progress since Tertiary time.

However, for this orogenic alteration of the regional precipitation distribution between the Nisling and the St. Elias glacial advances to have been caused by the St. Elias orogeny, the timespan between these two advances must have been considerably longer than any of the current literature suggests. For instance, one of the possibilities put forward by Hughes et al. (1969) was that the Nisling event may have been contemporaneous with the early Wisconsinan. However, assuming a net rate of orogenic rise in the order of $0.35 \mathrm{~mm} / \mathrm{yr}$ as postulated by Parrish (1981), the net uplift of the St. Elias Mountains during the period between an early Wisconsinan Nisling and a late Wisconsinan St. Elias maxima would be only approximately $15 \mathrm{~m}$. This certainly would have been an inadequate change in the elevation to have caused the indicated rain-shadow-induced differences in the extensiveness of ice coverage.

Despite the apparent anomalies, relatively little controversy has arisen over the attempts to establish a chronology for the various Cordilleran glaciations based on little more than estımates of the degrees of weathering of surviving surfaces, and differences in appearance of various drift deposits. However, it is of interest to note similar evidence and investigative methods applied to the interpretation of Atlantic coastal glacial events has stirred vigorous debate for decades. This dichotomy has led one of the leading protagonists in the Atlantic coastal debate to observe, "It is the more perplexing because similar field evidence from the Yukon, Alaska, the Rocky Mountains and Antarctica, often the subject of similar methods, has been uncontroversally accepted over decades by all researchers" (Ives, 1978). This current study was conceived as a tentative first step in re-opening this issue. 


\section{FIELD WORK}

\subsection{ORgANIZATION OF FIELD WORK}

\subsubsection{Study Area Zonation}

An air photo study and subsequent ground reconnaissance of the study area indicated that two separate zonation systems, one based on lithology and one based on glaciated surfaces, would be required to ensure adequate representative sampling. The lithological zonation is based on Muller's (1967) geological map (Map 1177A). This map indicates that the northern portion of the study area contains bedrock from two igneous units (Ruby Range Batholith and Nisling Range Alaskite). The southern portion of the study area contains two units of the mainly schistose Yukon Complex. It was decided for the purposes of transect layout and sampling to divide the study area in two, thereby creating a Lithological Zone 1 (the schist zone) and Lithological Zone 2 (the igneous zone). The inter-zonal boundary closely follows the general east-west line of Gladstone Creek/Gladstone Lakes (see Map 3.1). A more detailed description of the lithology of the area is presented in Chapter Five.

Air photo study and ground reconnaissance also established the adequacy of Muller's (1967) glaciation mapping for determining within the study area the upper ice-contact limits for the Nisling, Ruby and St. Elias glacial events (Map 1178A). Based on these upper ice-contact limits, the study area was divided into three ground surface zones (see Map 3.2), each of which contains that portion of the study area ground surface which is assumed to have been scoured by the same glacial event, and a fourth zone, the Pre-Nisling 


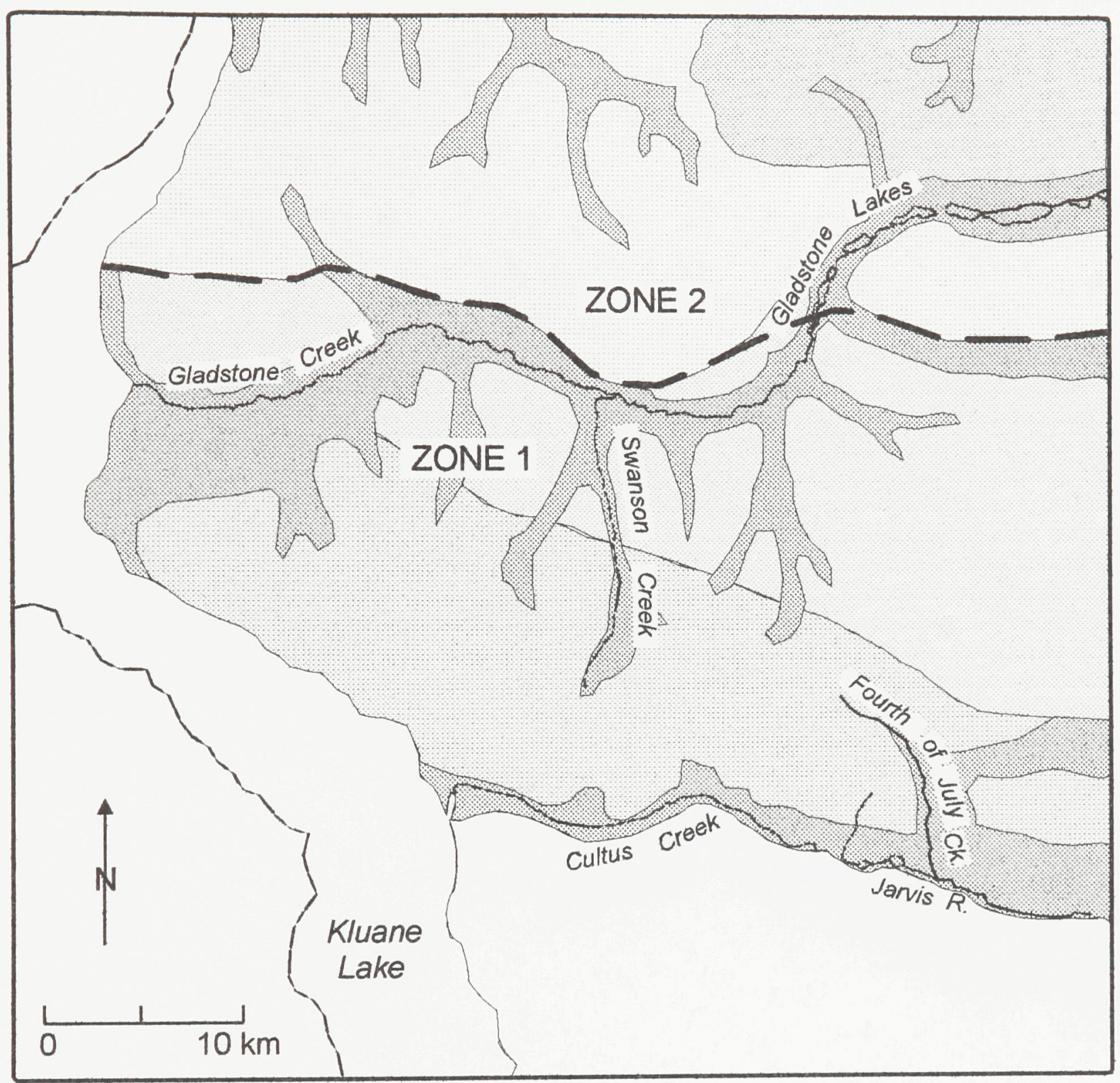

Lithology

- Interzonal Boundary

Drift-covered area

Zone 1:

$\square$ Quartz-biotite schist

$\square$ Quartz-muscovite schist

Zone 2:

$\square$ Ruby Range batholith

Nisling Range alaskite

Map 3.1: Study area lithology as derived from Muller (1967, Map 1177A). 


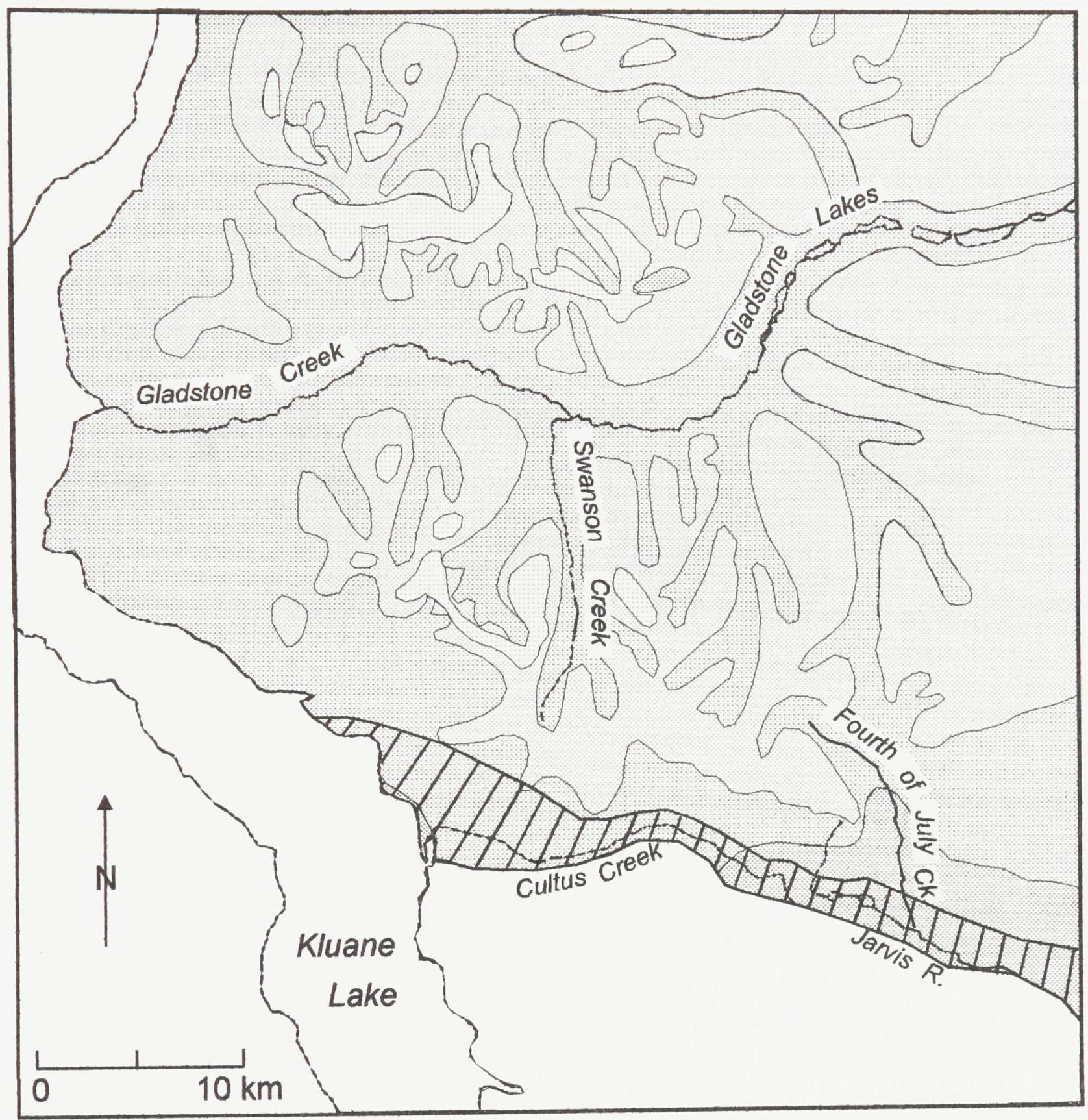

Ground Surface Zones

$\square$ Pre-Nisling

$\square$ Nisling

$\square$ Ruby

St. Elias Glacial Advance

Post-glacial

Map 3.2 : Study area ground surface zones as derived from Muller (1967, Map 1178A). 
Ground Surface Zone which extends above the Nisling upper ice-contact limit. Upon these latter surfaces, Muller (1967) could find no evidence of glaciation apart from isolated cirques.

In the text of Muller's (1967) memoir, he mentions the presence of "postglacial lake deposits" in valley bottoms throughout his map area. As will be discussed in more detail later in this chapter, the presence of these deposits were found to be important enough to justify the creation of a fifth zone, the Post-glacial Ground Surface Zone. The elevation limits of these five zones are summarized in Table 3.1.

Table 3.1: Northwest Ruby Range Study Area Ground Surface Zones

\begin{tabular}{|c|c|c|}
\hline Zone & Elevation Range (m) & Principal Features \\
\hline Pre-Nisling & $>1890$ & No unambiguous evidence of glacial scouring. \\
\hline Nisling & $1890-1431$ & Surface scoured by Nisling ice. \\
\hline Ruby & $1430-1098$ & Surface scoured by Ruby ice. \\
\hline St. Elias & $1430-1098$ & Surface scoured by St. Elias ice. \\
\hline Post-glacial & $<1098$ & Terraces and erosional detritus \\
\hline
\end{tabular}

\subsubsection{Sampling Plan}

Sampling was conducted along transect lines in both lithological zones (see Map 3.3). The transects were selected to give the most representative coverage of the study area commensurate with logistical limits, the most important of these being that all the sampling was to be carried out by a lone researcher over a limited period of time operating on a backpack basis. Fifteen transects were established in Lithological Zone 1 and were labeled " $1 \mathrm{~A}$ " to "1Q" omitting the letters, "l" and "O". In Lithological Zone 2, a further six transects were established and labeled " $2 A$ " to " $2 F$ ". In all, sampling was conducted at 121 sites along the Zone 1 transects and at 49 sites along the transects of Zone 2. Within Zone 1 , nineteen of the 121 sites were established within the biotite- 


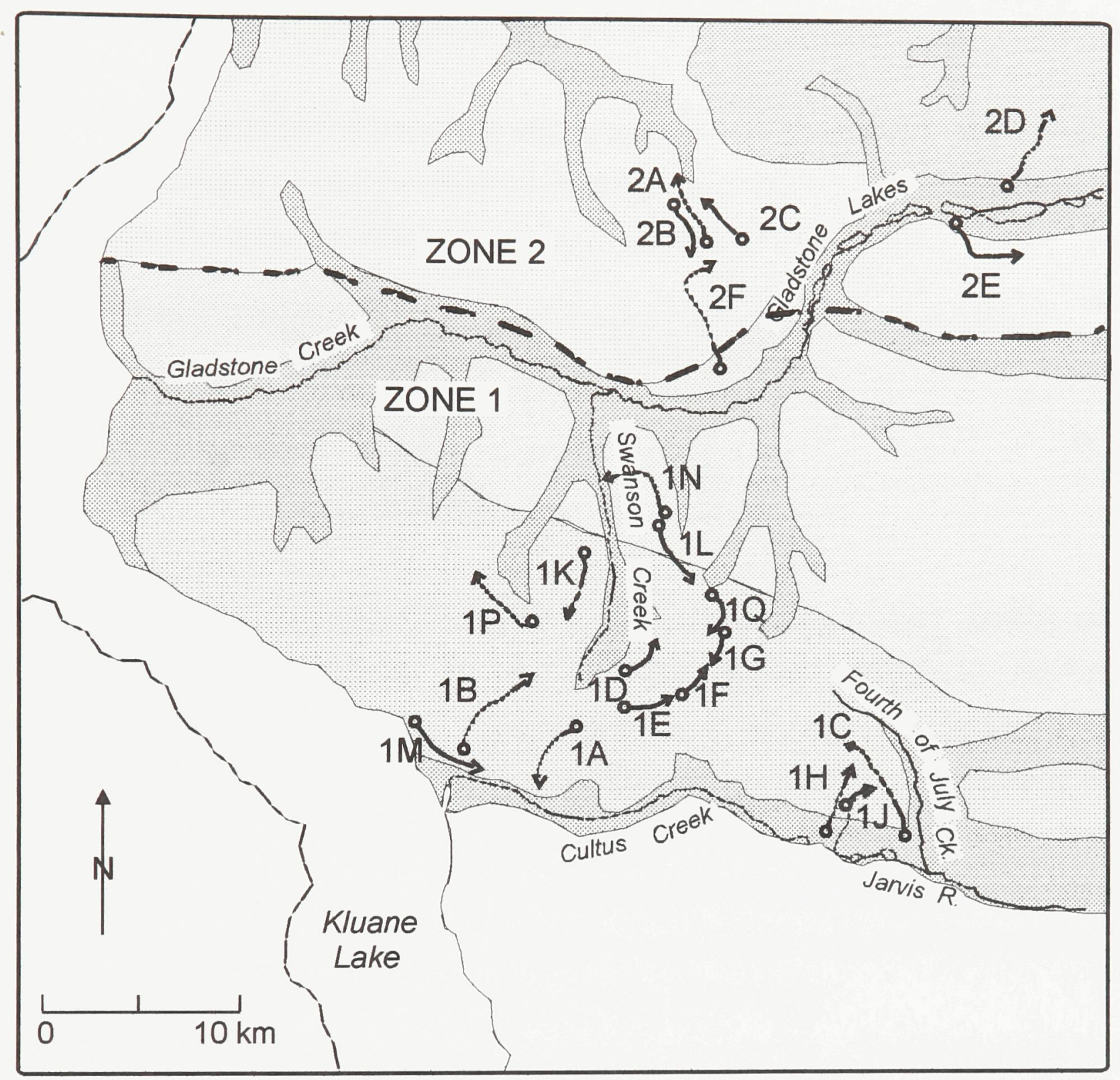

Lithology

- - Interzonal boundary

$\square$ Drift-covered area

Zone 1:

$\square$ Quartz-biotite schist

$\square$ Quartz-muscovite schist

Zone 2:

$\square$ Ruby Range batholith

$\square$ Nisling Range alaskite

Map 3.3 : Transect lines superimposed on a map of study area lithology as derived from Muller (1967, Map 1177A). 
schist unit. The remaining Zone 1 sites were located in the muscovite-schist unit. On hillslopes, the sites were spaced at approximately $30 \mathrm{~m}$ elevation intervals, and on level terrain they were spaced at roughly a $500 \mathrm{~m}$ horizontal distance apart.

The distribution of transects with respect to ground surface classification is shown in Map 3.4, and the distribution of individual sites in Lithological Zone 1 with respect to ground surface classes is summarized in Table 3.2.

Table 3.2: Distribution of Lithological Zone 1 Sites by Ground Surface Class

\begin{tabular}{cc} 
Ground Surface Class & Number of Sites \\
\hline Pre-Nisling & 44 \\
Nisling & 37 \\
Ruby & 12 \\
St. Elias & 15 \\
Post-glacial & 13
\end{tabular}

It will be noted that the higher-elevation Pre-Nisling and Nisling classes are somewhat over-represented. This is a result of measures undertaken in the final phases of the field work to resolve anomalies which had appeared in the earlier data. Although this potentially could have distorted the statistical analysis of the Lithological Zone 1 data, the statistical tools and procedures used were deliberately selected with a view to eliminating this possibility. This problem does not arise with the Zone 2 samples since these were not subjected to statistical analysis for reasons which will be explained later.

The layout of the transects is also not completely representative of the study area hillslopes. The literature review reported in the previous chapter indicated that a number of local ice-caps may have developed throughout the region during any of the three glacial events, and therefore it was feared that meltwater runoff might have severely eroded down-slope fine-fraction layers below such ice cap sites. In order to reduce the risk of including such eroded 


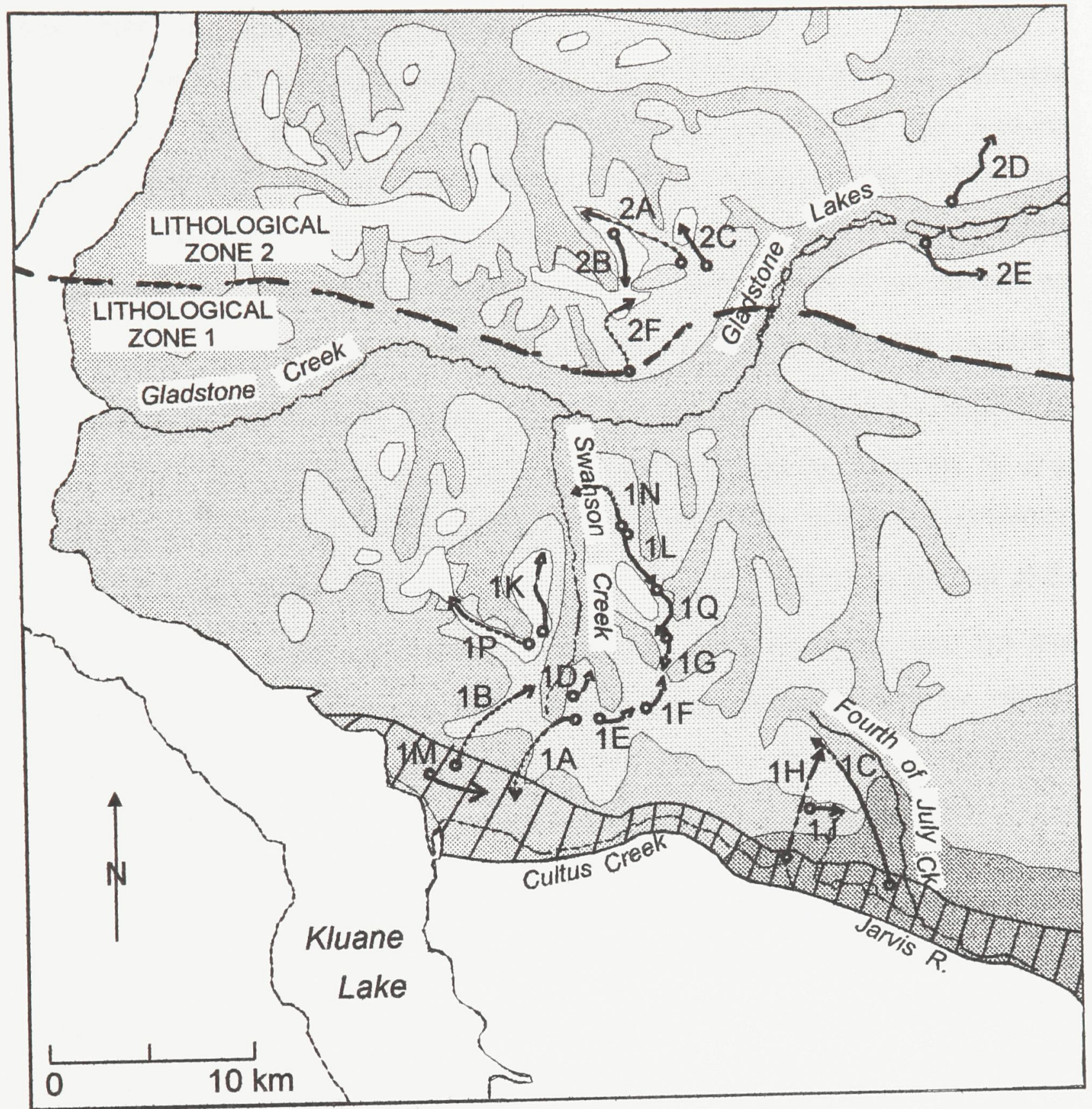

Ground Surface Zones

$\square$ Pre-Nisling

7 Nisling

Ruby

St. Elias Glacial Advance

Post-glacial

- - Lithological Zonal Boundary

$\longrightarrow$ Transect Lines

Map 3.4 : Transect lines superimposed on a map of study area ground surface zones as derived from Muller (1967, Map 1178A). 
surfaces in the sampling, all hillslope gullies were avoided. In addition, all suspected landslide sites were avoided.

Fixation of individual site locations was accomplished by map, compass, pedometer, and aneroid barometer. The maps used were the National Topographic A722 Series, 1983 edition, 1:50,000 scale, sheets $115 \mathrm{G} / 1$ and $115 \mathrm{G} / 8$. The contour interval for this series is 100 feet $(30 \mathrm{~m})$ : Previous survey experience in similar terrain indicated that this combination of equipment will provide horizontal fixation of a location to an accuracy of $\pm 50 \mathrm{~m}$ fifty percent of the time and $\pm 100 \mathrm{~m}$ ninety percent of the time. Site elevations were determined by a single aneroid barometer calibrated as frequently as possible by map contours at clearly identifiable points. This system under similar circumstances in the past has yielded elevation accuracy in the order $\pm 30 \mathrm{~m}$ fifty percent of the time and $\pm 100 \mathrm{~m}$ ninety percent of the time. This accuracy was the best achievable with the available resources, and was considered to be reliable enough for statistical purposes when sample batches from ten or more sites were involved.

In five summer field seasons, 1991 through 1995, a total of 206 finefraction and 153 rock samples were collected. Average sample weight for both fine-fraction and rock samples was $150 \mathrm{~g}$. The relatively small sample weight was dictated by the limitations of backpack transportation. It was found that in almost all instances throughout the regolithic fine-fraction, individual soil horizons could not be identified. In almost all sites, the fine-fraction materials are interspersed with the scree. The practical difficulties of digging in such conditions, limited the excavation of soil pits to approximately 30 to $50 \mathrm{~cm}$ below the vegetation mat. In a limited number of instances, penetrations of up to one meter were achieved with a soil-auger, but in each case the presence of ice crystals in the extracted material at approximately the one-meter depth indicated the presence of permafrost. This confirmed previous experiences in the adjacent Duke River 
valley at comparable elevations where permafrost was frequently encountered at a depth of approximately one meter (Howes, 1991).

Field tests of the fine-fraction indicated a range of textures from sandy loam to silt loam, with only one undisturbed site yielding a significant clay-size fraction (Site 1C1). Rock samples were collected from bedrock outcrops whenever they were encountered. In addition, a limited number of erratic and scree clasts were collected, but these were always clearly labeled as such to avoid confusion with the bedrock samples. Whenever possible, the weathering rind was collected and packaged separately from the unweathered portion of the same specimen.

\subsection{Field ObSERVATIONS}

During the course of the field work, some features within the study area, first identified from air photos, and certain other features and characteristics of materials, which proved to have a significant impact on the eventual outcome of the study, were subjected to special scrutiny in the field. The results of those field investigations are reported below.

\subsubsection{Tertiary Relicts}

As described in Chapter Two, Eisbacher and Hopkins (1977) reported the presence of mid- to late-Tertiary diamicton deposits on Amphitheatre Mountain approximately $35 \mathrm{~km}$ west of the study area (see Map 1.2). Madole (1982) reported the presence of diamicton deposits, which he took to be of Tertiary age, on ridge tops and cols of the Colorado Front Range in the western United States. If such relicts of Tertiary surfaces can survive the tectonic disruption of the Cordilleran orogeny, then it is reasonable to assume that relicts of such surfaces should also have survived the tectonic events which have taken place during the same period within the northwest Ruby Range study area. 
During my initial reconnaissance, I located the remnants of the deposit on Amphitheatre Mountain reported by Eisbacher and Hopkins (1977). It was my intention to sample it with the expectation that it would provide a weathering benchmark for dating Tertiary relict deposits which might be found within the study area. However, only a single fragment of the original deposit remained, and this fragment was so precariously perched that it was deemed unsafe to attempt to sample it. In any case, no similar deposits were subsequently found within the study area.

\subsubsection{Advanced-Weathering Features}

Felsenmeer was encountered at 33 Lithological Zone 1 (mica-schist) sites and at 4 Zone 2 (igneous) sites. All felsenmeer sites were found exclusively in the Pre-Nisling Ground Surface Zone. Within two of the Pre-Nisling sites in Zone 2 , granitic tors were found on transects $2 \mathrm{~A}$ and $2 \mathrm{~B}$. At these sites and in their immediate vicinity, other forms of advanced weathering were also encountered. On Site 2B1, grus was found amid the tors, and one block was covered with a weathering rind $25 \mathrm{~cm}$ thick. A large weathering pit was also found at Site 2B1, and several smaller ones at nearby Site 2A4 at 2000m elevation.

The age of similar features on the North American Atlantic coast has been the subject of vigorous debate for over a century. Early researchers on Atlantic North American glaciation argued that high mountain areas from Labrador to New England either remained as nunataks or else had been occupied only by local ice caps, and cirque and valley glaciers throughout the Wisconsinan. Therefore these workers maintained that features found in these areas, such as block fields (felsenmeer), tors and weathering pits, pre-dated the Wisconsinan (Bell, 1884), (Chalmers, 1896), (Daly, 1902) and (Coleman, 1920).

Later researchers, Odell (1933, 1938), Flint (1943), and Tanner (1944)

were dubious of the "nunatak hypothesis." Odell $(1933,1938)$ in particular postulated that the felsenmeer could easily have formed since the Wisconsinan 
maximum due to vigorous Arctic maritime freeze-thaw frost shattering. Based on his work in mountainous areas near Narvik, Norway, Dahl (1966) supported this view and offered the opinion that weathering pits in otherwise well-preserved blocks in the block fields do not preclude the possibility that they were formed during the long post-glacial period in the summit areas.

More recent debate was equally inconclusive. Ives (1978) put forward two hypotheses concerning the glaciation of the Torngat Mountains of Labrador. In the first hypothesis, Ives (1978) postulated that the three glacial erosion zones identified resulted from stades of the Wisconsinan, in the second, he postulated that the lowest zone was created during the Wisconsinan maximum, and the upper two during pre-Sangamon glaciations. At much the same time, Sugden (1977) was proposing that all three zones can be related to Late-Wisconsinan temperature variations and/or basal ice dynamics. However, both researchers were in agreement that the advanced-weathering features described above could have survived some degree of glaciation. Ives (1978) does not preclude the possibility that ice carapaces may have formed on many of these supposedly "unglaciated" surfaces, and Sugden (1977) maintained that pre-glacial weathering features can survive the passage of cold-based glaciers.

Within the context of the glaciation of the northwest Ruby range, the hypotheses put forward during the Atlantic Coast debate suggest that the presence of felsenmeer on Pre-Nisling surfaces does not preclude the possibility that these sites have endured some form of glaciation. It now appears possible that some or all of these sites might have been occupied by local ice-caps or some form of cold-based glaciation.

In subsequent $X$-ray diffraction analysis of rock samples from Pre-Nisling surfaces, a significant finding emerged. Such advanced-weathering features as tors, weathering pits, abnormally thick rinds and the presence of grus were only found on Zone 2 Pre-Nisling sites in which the bedrock samples were found to contain an abundance of biotite. These same weathering features were not found on other Zone 2 Pre-Nisling sites, but weathering rinds up to $7 \mathrm{~cm}$ thick 
were found on outcrops of felsic rock containing an abundance of biotite on Site $2 \mathrm{D} 7$ at an elevation of $1737 \mathrm{~m}-153 \mathrm{~m}$ below the Pre-Nisling lower limit. Considering the known propensity of biotite to swell under surface conditions through the process of hydration (MacEwan and Wilson, 1980), the possibility is raised that the advanced weathering observed on the some Pre-Nisling surfaces may have been more a consequence of mineral composition than of great age.

\subsubsection{Hillslope Features}

A number of glacial features were observed on hillslopes in the Nisling, Ruby and St. Elias ground surface zones, and are worthy of comment.

\subsubsection{Erratics}

Several erratic clasts were observed in Lithological Zone 1, however, no clasts which could be unequivocally identified as erratic were located in Zone 2. The problem in Zone 2 lies in the variety of mineral assemblages in the local bedrock. Only one small clast $(\phi=3 \mathrm{~cm})$, which was strongly suspected of being an erratic, was found in this zone - on Transect $2 \mathrm{C}$ at an elevation of $1825 \mathrm{~m}$ on a Nisling ground surface. This clast appeared to consist of pure quartz of a type that is frequently encountered in large veins in Zone 1 mica schist. However, as such quartz veins could also exist in the Ruby Range Batholith, the possibility that this particular clast was of local origin could not be excluded.

In Lithological Zone 1, the problem of identifying erratics is simplified by the homogeneity of the local bedrock. Here, igneous rock is clearly an erratic, and several such examples were found on Zone 1 hillslopes. On Transect 1A, for example, two horizontal belts of granitic erratics were located at $1420 \mathrm{~m}$ and $1310 \mathrm{~m}$ elevations. The upper belt consists of several large granitic boulders $(\phi>1 \mathrm{~m})$ interspersed with fewer rounded and smaller granite and rhyolite pebbles $(\phi<5 \mathrm{~cm})$. The larger granite erratics have rinds some $1.5-2.5 \mathrm{~mm}$ thick; the 
rhyolite erratics have none. In the case of the larger granitic erratics, evidence of sub-surface weathering is limited to roughened texture. This belt of erratics lies approximately $10-15 \mathrm{~m}$ above a small terrace some $40 \mathrm{~m}$ long and $15 \mathrm{~m}$ wide which, as discussed later, appears to be an ice-marginal terrace fragment.

In the lower belt, the larger erratic granitic boulders have roughened surfaces (pitting) both above and below ground surface. Between the boulders, many small $(\phi=3-5 \mathrm{~cm})$ rounded pebbles of possible glaciofluvial origin were found. As was the case within the upper belt, the erratic material of the lower belt lies approximately $10 \mathrm{~m}$ above another terrace this one being some $30 \mathrm{~m}$ long and $15 \mathrm{~m}$ wide.

This double belt distribution of erratic material was not observed on other Zone 1 transects. On Transect 1B, many sub-angular-to-rounded gravel-sized erratics were found at $940 \mathrm{~m}$ elevation (Post-glacial surface) around a large $(\phi=1.8 \mathrm{~m})$ rhyolite boulder none of which displayed any obvious signs of weathering. On the same transect at $1030 \mathrm{~m}$ elevation, a large $(\phi=1.5 \mathrm{~m})$ granitic erratic displayed no obvious signs of weathering. Smaller $(\phi<35 \mathrm{~cm})$ felsic erratics with no visible weathering were found on the Ruby ground surface at $1215 \mathrm{~m}$ elevation. Within the Transect 1B Nisling Ground Surface Zone, several granitic erratics were found at $1490 \mathrm{~m}$ elevation with $3 \mathrm{~mm}$ of rind on exposed surfaces and none on below-ground surfaces, but above them at $1580 \mathrm{~m}$, a large $(\phi=1.5 \mathrm{~m})$ granitic erratic was found with no signs of weathering at all.

Further confusing weathering patterns were found on erratic materials on Transect $1 \mathrm{H}$. There was no evidence of weathering on granitic erratics on this transect in the Ruby zone at $1215 \mathrm{~m}$ elevation and at $1325 \mathrm{~m}$ elevation. There was also a granitic erratic at $1520 \mathrm{~m}$ (Nisling zone) which bore no visible signs of weathering whereas small $(\phi<25 \mathrm{~cm})$ granitic erratics lying in the bottom of a subglacial meltwater channel at $1660 \mathrm{~m}$ elevation showed signs of pitting on above-ground surfaces, but none on below-ground surfaces. 
Birkeland (1984) presented considerable data on the dating of tills based on the presence and thickness of weathering rinds on boulders of various lithologies in the western United States and on the relative abundance of these lithologies in the surviving till deposits. However, as can be seen from the above descriptions of erratic weathering in the northwest Ruby Range study area, Birkeland's (1984) data are of no practical assistance in determining the age of the northwest Ruby Range ground surfaces. Some of the least-weathered erratics were found at some of the highest elevations on the study-area hillslopes. Considering the conflicting evidence observed in the field, the degree of weathering of erratic casts does not provide a basis for estimating the date of deposition. It is suspected that the degree of weathering observed on individual erratics may be more a function of pre-existing weathering prior to deposition, or, alternatively, of site-specific micro-climate factors at the point of deposition. However, the data collected during this study are inadequate to make a satisfactory assessment of the relative contributions of these factors.

\subsubsection{Ice-Marginal Features}

A number of terrace-like fragments were encountered on Lithological Zone 1 Nisling, Ruby and St. Elias ground surfaces. Resource limitations dictated that examination of these structures would have to be restricted to visual observations of their surface features. Three more of these fragments were found on Transect $1 \mathrm{~A}$. The lowest of these, which was found at $1310 \mathrm{~m}$ elevation (Ruby surface), was approxımately $15 \mathrm{~m}$ wide and $40 \mathrm{~m}$ in length. Numerous rounded pebbles of various lithologies were found on its surface. No such pebbles were found on any of the other fragments. Two other terrace-like fragments, one, at $1380 \mathrm{~m}$ elevation in the Ruby zone, measured approximately $15 \mathrm{~m}$ in width and $40 \mathrm{~m}$ in length, and the second, at the Ruby/Nisling boundary $(1430 \mathrm{~m})$, measured $30 \mathrm{~m}$ in width and $40 \mathrm{~m}$ in length.

Two more terrace-like fragments were found on Transect $1 \mathrm{~B}$ at different elevations. One, at $1400 \mathrm{~m}$ (Ruby zone), was found to have numerous sub- 
angular to rounded cobble-sized erratics on its surface and also protruding from the bank surface. The second terrace-like fragment on Transect $1 \mathrm{~B}$ was found at $1675 \mathrm{~m}$ elevation in the Nisling ground surface zone.

The largest of all these features was found in the St. Elias Ground Surface Zone on Transect $1 \mathrm{C}$ at an elevation of $1370 \mathrm{~m}$. It was found to be approximately $75 \mathrm{~m}$ in width and to have extended some $300 \mathrm{~m}$ in length. It is assumed that its greater length is due to less erosion than that experienced by those terrace-like features that were deposited on older ground surfaces by earlier glacial events.

Without a full investigation of the sub-surface characteristics of these features, the processes by which these terrace-like fragments were formed cannot be identified with certainty. However, the deposition of glaciallytransported debris during meltwater ponding along the margins of valley glaciers is suspected. If this is true, then the variations in elevation at which these fragments are found suggest that these features may be remnants of terraces formed during successive still-stands in a period of deglaciation. As will be described later, terraces composed of similar materials were found along the lower slopes of both the Cultus Creek and Jarvis River valleys.

The presence of the terrace-like fragments proved, in the light of subsequent laboratory investigation, to have been clues that glaciallytransported, fine-fraction materials may have contaminated the regolithic finefraction covering the Nisling, Ruby and St. Elias ground surface zones. It was consideration of this possibility which gave rise to the Additional-Materials Hypothesis described in Chapter One. 


\subsubsection{Valley Bottom Features}

\subsubsection{Moraines}

An examination of the air photos of valley bottom features within the study area revealed the existence of at least two arcuate moraines stretching across the Gladstone Creek valley in the Ruby Ground Surface Zone. Due to limitations of time and distance, neither of these two moraines were visited during the field work, and hence the following observations are based on air photo examination only. The first moraine is located approximately $20 \mathrm{~km}$ upstream from the Gladstone Creek delta. The south end of the moraine has been breached by the modern Gladstone Creek. This moraine appears to be less heavily eroded than the second moraine which straddles the valley at a point approximately $3 \mathrm{~km}$ further east, and which has also been breached on its southern flank by the modern Gladstone Creek. Their arcuate shapes indicate that both were formed by a valley glacier which had advanced eastward up the Gladstone Creek from the direction of the Shakwak Trench (see Map 1.2). The fact that the easternmost moraine appears to be the most heavily eroded suggests that the westernmost of the two was formed as the result of a temporary re-advance during the deglaciation phase of the Ruby glacial event. Neither an air photo study nor a ground search revealed the presence of Ruby moraines in the Cultus Creek valley despite similarities in the configurations of both valleys and their positions vis à vis the Shakwak Trench. The answer to this anomaly may lie in the differences between the two valleys rather than in their similarities. The average elevation of the Gladstone valley floor is approximately $200 \mathrm{~m}$ higher. In addition, the Gladstone valley had a greater number of relatively larger tributary valleys which were also glaciated in Ruby time. The third major difference between the two valleys is that, while both offered access to ice advancing northwestward through the Shakwak Trench, the entrance to the Cultus valley lies $20 \mathrm{~km}$ southwest of the Gladstone entrance. This suggests that the volume of ice in the Shakwak Trench at the Cultus entrance would have been greater than 
the volume of ice in the same lobe at the Gladstone entrance. These three differences combined could have significantly altered the glaciation and deglaciation processes in the two valleys resulting in one having a series of moraines and the other not.

Despite the absence of Ruby moraines in the Cultus Creek valley, the air photos of the area show that a moraine once straddled the Cultus/Jarvis divide approximately $700 \mathrm{~m}$ east of the advance limit of the westward-flowing St. Elias lobe (see Map 3.2). A visit to the site yielded little useful additional information due to extensive stripping of the moraine during construction of the adjacent mining road. However, the air photos clearly indicate that the south flank of the moraine had been breached, possibly by meltwater which flowed down a steep gradient over the south wall of Cultus/Jarvis glacial trough. The channel through the breach is currently occupied by an underfit stream which is unlikely to have had sufficient erosive power to have created the breach in modern times. This leads to the conclusion that the moraine was probably breached much earlier while there was still St. Elias ice in the vicinity. It is suspected that, until it was breached, this moraine may have served as a dam which allowed the impoundment of meltwater at the margins of the St. Elias lobe.

\subsubsection{Lacustrine Deposits}

Muller (1967, p.15) reported the presence of post-glacial lake deposits in the region, and specifically of deposits in the Cultus Creek valley: "Lake silts over 100 [30m] feet thick, with ice-freighted striated cobbles, occur on Cultus Creek well above the $3,000-$ foot $[900 \mathrm{~m}]$ topographic contour and indicate a lake connection through Cultus Creek and Jarvis River valleys to glacial Lake Kloo which...stood at an elevation of about 3,000 feet [900m]." These deposits were examined in some detail during the current study, and my findings do not completely support this lake-connection hypothesis for the reasons outlined below. 
There are, in fact, two separate sets of such deposits in the adjoining Cultus Creek and Jarvis River valleys. In the Cultus Creek valley, these deposits take the form of a line of double terraces (Plate 3) - the upper terrace at $915 \mathrm{~m}$ elevation and the lower at $850 \mathrm{~m}$ elevation. This double-terrace structure is found on both sides of the valley. The terraces are vegetated both on top and on the sides, making it impossible with the time and resources available to verify the presence of embedded ice-rafted cobbles, clearly identifiable beach cobbles, or other such diagnostic features.

The second set of terraces (Plate 3 ) located east of the Cultus/Jarvis divide consists of single terraces on both sides of the valley at an elevation of $850 \mathrm{~m}$. Unlike the Cultus Creek terraces, these have been deeply incised by a number of modern tributary streams, and the banks of these incisions have remained unvegetated allowing easy examination of the cross-sectional structure of these deposits. The deposits were found to consist of isolated rounded, sub-angular and flatiron-shaped cobbles suspended in a silt-loam matrix which appears to lack bedding. Many of the cobbles were erratic, but some consisted of mica schist common to this part of the study area. None bore identifiable striations. Despite this, their shape and suspension in a silt-loam matrix are consistent with them being ice-rafted cobbles embedded in proglacial lake bottom sediments.

However, terraces on opposite sides of the valley are separated by a distance of approximately $800 \mathrm{~m}$ in some places. If, in fact these terraces are the remnants of lake bottom sediments, a large quantity of the original lake bottom sediments has been removed from what is now an empty space between them. This would appear to be well beyond the erosive capability of the modern underfit stream, and no evidence was found of large-scale re-deposition which could account for the missing volume of sediments. The fact that this second set of terraces lies immediately behind the St. Elias moraine astride the Cultus/Jarvis divide suggests that this moraine may have served as the dam behind which the meltwater from the St. Elias lobe was impounded in front of 

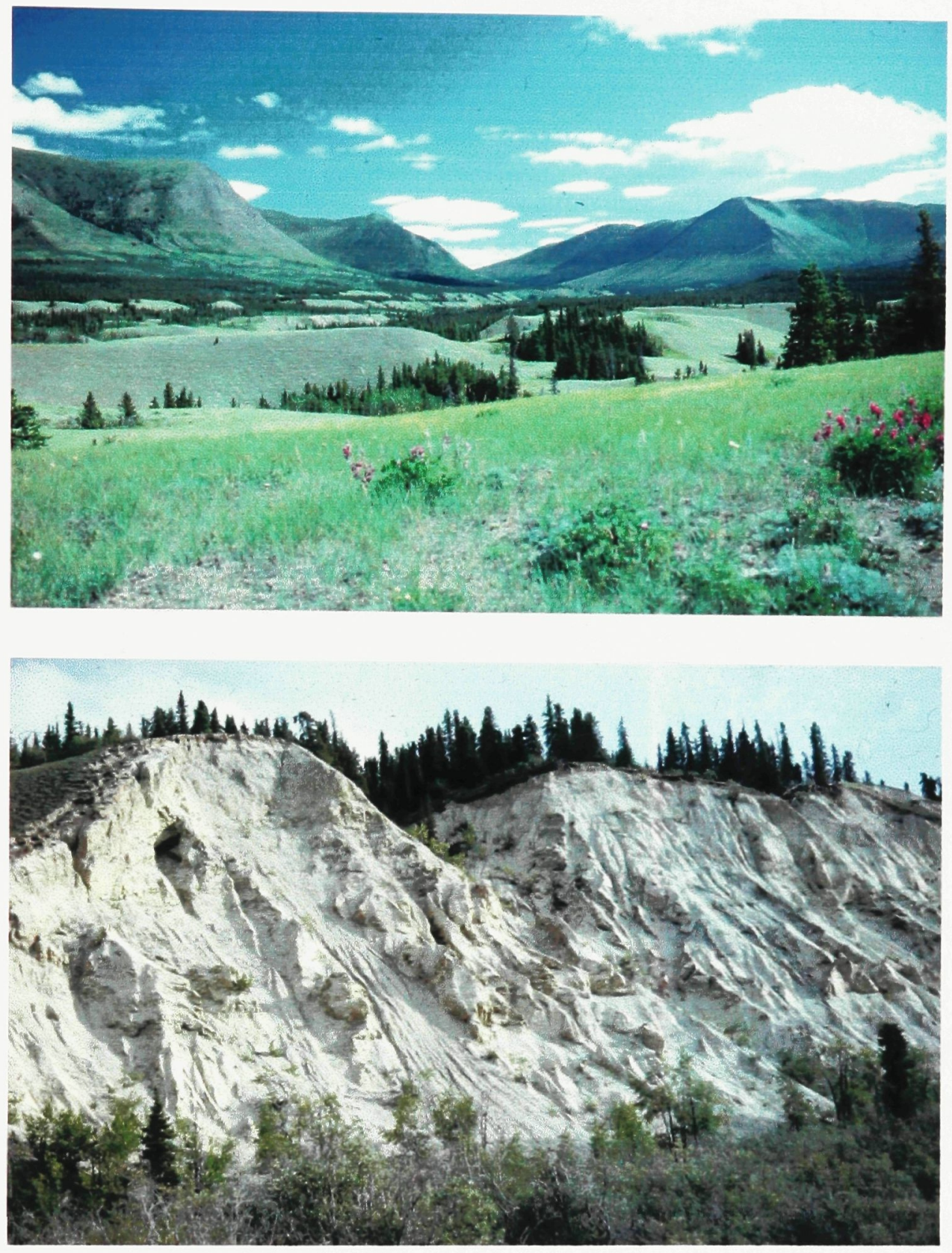

Plate 3: Terraces in the Post-glacial Ground Surface Zone. Top: A view of these features in the Cultus Creek Valley. Bottom: Similar features east of the Jarvis/Cultus divide. 
and around the margins of the lobe. This could explain the twin-terrace structure of the sediments.

The similarities between this set of terraces and the set in the Cultus Creek valley suggest that the latter set of terraces may also have formed under similar circumstances. However, according to Muller (1967), the last ice to advance into the Cultus Creek valley did so during the Ruby glacial event. Therefore, it is unlikely that there ever was a connection between the body of water which deposited these sediments in Ruby time and Kloo Lake whose origin is believed to date from the late- or post-St. Elias period. In the case of the deposits east of the Jarvis/Cultus divide, it also appears unlikely that there was any significant connection between the meltwater impounded there and Kloo Lake. The evidence suggests that, at the time that impoundment took place in the late-St. Elias glacial event, there probably was still approximately $30 \mathrm{~km}$ of ice between that body of water and Kloo Lake.

\subsubsection{Fine-Fraction Materials}

\subsubsection{Fine-Fraction Profiles}

It was anticipated that the regolithic fine-fraction would have developed pedogenic soil horizons. Such horizons would have been invaluable in interpreting the climatic history and glacial chronology of the study area. The discovery of Tertiary-age diamicton on nearby Amphitheatre Mountain and other Cordilleran regions encouraged the belief that paleosols may have survived on the higher surfaces of the study area, and would have provided substantial proof that, apart from local ice caps, Pre-Nisling surfaces had remained unglaciated throughout the Quaternary. Unfortunately, the existence of soil horizons within the study area proved to be the exception rather than the rule. Soil horizons were found along the eastern shore of Kluane Lake and in isolated valley bottom deposits east of the Jarvis/Cultus divide. Elsewhere the upper layer of the 
regolith consisted of an undifferentiated mixture of organic and mineral matter. The textural range of the mineral matter encompassed a fine fraction that was normally either a sandy loam or a silt loam, and a coarse fraction that ranged from gravel to 4-meter blocks.

Typical of the soil profiles along the eastern shore of Kluane Lake is a loess deposit which was found on the surface of what appears to be dead-ice topography at the mouth of Cultus Creek. The sequence is given in Table 3.3.

Table 3.3: Profile of a loess deposit at the mouth of Cultus Creek

\begin{tabular}{ll}
\multicolumn{1}{c}{ Depth } & \multicolumn{1}{c}{ Description } \\
\hline $0-35 \mathrm{~cm}$ & Neoglacial Loess \\
$35-37 \mathrm{~cm}$ & volcanic ash \\
$37-87 \mathrm{~cm}$ & Neoglacial Loess (abrupt lower boundary) \\
$87-130 \mathrm{~cm}$ & oxidized Kluane Loess (C horizon missing) \\
$130 \mathrm{~cm}+$ & unsorted rounded clasts (drift?)
\end{tabular}

This sequence matches, in most aspects, the Slims River valley loess profile described by Borns and Goldthwait (1966). The major exception is that the Cultus Creek sequence contains no unoxidized Kluane Loess parent material. In the Slims River valley profile, the oxidized Kluane Loess is superimposed on an unoxodized horizon, and these two horizons in combination form the Slims Soil palaeosol. The fact that the unweathered horizon is missing at the Cultus Creek site suggests that either the oxidized loess may have been re-deposited from windward Slims Soil deposits further west, or that the loess oxidized fully in its present location.

\subsubsection{Clay-Rich Horizons}

The general absence of soil horizons in the study-area fine-fraction materials imposed a severe limitation on the possibility of identifying altered phyllosilicates which may have formed within the fine-fraction as a result of 
prolonged weathering processes. Such alteration products would normally be found in their most concentrated form in the clay-size fraction. However, even in normal-sized sandy-loam and silt-loam samples, the clay fraction is minuscule. This, when combined with the logistic limitation on soil-sample sizes, meant that evidence of advanced phyllosilicate alteration could only be examined in a dispersed form in whole-soil samples. The practical limitation of whole-soil analysis is that only the more extreme cases of phyllosilicate alteration would be identified.

Only one useable clay-rich sample (Site $1 \mathrm{C} 1$ at the base of transect $1 \mathrm{C}$ ) was found. In fact, in the entire study area, only two other clay-rich sites were located. These other two sites were located on Fourth of July Creek, a short distance downstream from an active placer tailings pond, which excluded their use for study purposes. The clay horizons had been exposed by bulldozer at a depth of $1.5 \mathrm{~m}$. The top of the clay layer in both instances was approximately $20 \mathrm{~cm}$ above the mid-summer water table. Its thickness is unknown.

At Site $1 \mathrm{C} 1$ a pit was dug, and a single clay-rich sample was taken. This site is located near the source of the Jarvis River. It lies upstream from the confluence of the Jarvis River and Fourth of July Creek, and, as such, is free of contamination from the placer operation on Fourth of July Creek. Field testing of the sample for texture indicated that it is a clay-loam. Although two other pits were dug further upstream in the vicinity of the Jarvis/Cultus divide, no other clay-rich horizon was encountered.

\subsubsection{Loess Deposition at Higher Elevations}

At two sites on Transects $1 \mathrm{~K}$ and $1 \mathrm{~L}$, at approximately $2300 \mathrm{~m}$ elevation, a thin dusting of volcanic ash was found on the surface of other fine-fraction materials. This ash deposit differed from all others seen within both the study area and further west in the Slims River valley in that this ash had not been covered by subsequent loess deposition. There has been only one volcanic 
event (the second White River eruption) which is known to have produced a tephra lobe that extended into the study area. The most recent ${ }^{14} \mathrm{C}$ dating, based on a weighted mean of four calibrated ages, ascribed a date for this eruption of 1147 years B.P. or AD 803 (Clague et al., 1995). One concludes from this that the deposition of loess at this elevation has been insignificant since at least that time. The reason for this may be limitations on the transport capacity of modern winds, because above the surface of Kluane Lake immediately adjacent to the study area, one frequently sees clouds of loess, and loess deposits several centimeters deep are encountered along the eastern shoreline of the lake (see Table 3.3), but none are found at higher elevations.

\subsubsection{Significance}

These field observations would prove to have significant effects on the outcome of the study. Initially, it had been planned to use fine-fraction material from the diamicton on Amphitheatre Mountain to establish weathering criteria by which to identify Tertiary-age deposits in the study area. However, the Amphitheatre mountain deposit proved to be inaccessible, and the inability to locate deposits of similar age within the study area forced the abandonment of this line of investigation. The observation of the limited geographic extent of advanced-weathering features proved to be an early indicator that these features might be more a function of mineral composition than of great age. The confusing pattern of erratic weathering closed off another normally useful line of investigation as did the general lack of pedogenic horizons and clay-rich horizons.

Other features, however, did provide useful positive information. The identification of moraines was useful in identifying the direction of deglaciation in the Gladstone Creek valley. In addition, the presence of a moraine in the vicinity of the Cultus/Jarvis divide provided a plausible explanation of how meltwater could have been impounded around the St. Elias lobe in the Jarvis River valley. 
However, perhaps the most important observations with respect to outcome of the study were indications that the regolithic fine-fraction might have been significantly contaminated by loess and volcanic ash deposits, and that glaciofluvial and/or lacustrine fines from terraces and terrace-like remnants could have had a similar effect. 


\section{PHYLLOSILICATE ALTERATION}

\subsection{BenCHMARK SELECTION}

No single regional model exists that could be used by itself to gauge a chronosequence based on weathering patterns in a semi-arid, periglacial upland region such as the northwest Ruby Range. The literature does contain, however, a few examples of phyllosilicate alteration which should provide benchmark data concerning such processes over time which can be used to assess the amount of time required to produce the degrees of alteration found within the northwest Ruby Range study area. Therefore, for the purposes of this study, selected previous phyllosilicate alteration case studies, which were undertaken in a range of climate and topographical conditions from the polar desert conditions of Wright Valley, Antarctica to the temperate upland conditions of the Cape Breton Highlands, are reviewed. Included is a report of vermiculitization in the central Yukon which lies adjacent to and northeast of the Ruby Range.

\subsubsection{Alteration in Polar Desert Conditions}

Ugolini and Bull (1965) reported a chronosequence of soils in western Wright Valley, Antarctica. Relative dating was determined from measurements of variations in the amounts of clay, salt, calcium carbonate and free iron oxides in a number of soil profiles which developed on moraines from three successively older glaciations. Absolute dating of these glaciations was provided by correlation to outside glacial events on the Ross Ice Shelf based on subsequent work by Stuiver et al. (1979). The dates so derived for the Wright Valley soils 
range between 3,100 to 850,000 yrs. B.P. No differences were found in the clay mineral suites within the chronosequence.

Subsequent work in the vicinity by Ugolini and Jackson (1977) on a soil derived from granitic residuum, found on a bench in Bull Pass above the valley, showed clear evidence of transformation over time. They postulate that the following weathering sequence takes place: feldspar $\Rightarrow$ mica $\Rightarrow$ montmorillonite $\Rightarrow$ chloritized montmorillonite. From the same site, pedogenic mica particles were dated by the fission track replica method at $4.1 \pm 0.2 \mathrm{MY}$ (Jackson et al., 1977).

In later years, another chronosequence of soils, in Taylor Valley, Antarctica, was analyzed by Bockheim (1980). Although temperatures rarely exceeded $0^{\circ} \mathrm{C}$ and soil moisture conditions were less than $2 \%$, Bockheim (1980) found evidence of mica hydration based on a broadening of the (001) mica reflection. However, although the soils ranged from 200,000 to possibly $3 \mathrm{Ma}$ in age, no other clay transformations were recorded.

In arctic Canada, Bockheim (1980) noted that Evans and Cameron (1979) reported a reduction in mica and an increase in vermiculite with soil age on southern Baffin Island. This confirmed earlier work in the same area by Ugolini and Jackson (1977), who speculated the vermiculites that they had found may represent a weathering product of mica, and that the montmorillonite that they also found had probably weathered from the vermiculite.

\subsubsection{Alteration in Temperate Montane Regions}

Shroba (1977) reported that, in the alpine environment of the Colorado Rocky Mountains, mica was still present in the soils after approximately $10^{4}$ years of weathering, but the $\mathrm{X}$-ray diffraction records displayed a low intensity (001) mica peak with a mixed-layer $(10-18 \AA)$ phyllosilicate as the main transformation product. Within $\pm 100 \mathrm{~m}$ of the present tree-line (which may be below an earlier tree-line) the mica alteration was found to have been more 
intense, with vermiculite present in addition to the mixed-layer phyllosilicates. By comparison, in a wetter, leaching alpine environment in New Zealand, Birkeland (1984) found nearly total elimination of the original chlorite and mica within $10^{4}$ years and their transformation to mica-vermiculite, mica-chlorite, and micasmectite.

Dixon's (1986) work in Holocene age cirque catenas in the Colorado Front Range established that, although biotite was extensively altered in numerous profiles, quartz, feldspar and chlorite showed no evidence of transformation to secondary clay minerals. Biotite was found to alter to smectite in some locations and to vermiculite in others. At higher topographic positions, biotite X-ray diffraction peaks were more intense and more symmetrical in shape, suggesting substantially less weathering than was the case at lower topographic positions.

\subsubsection{Alteration in Late- and Post-Wisconsinan Canadian Soils}

Ross et al. (1984) investigated post-Wisconsinan soil chronosequences in the Hudson Bay coastal zone. They found that the abundance of vermiculite had increased linearly with time and was associated with a decrease in mica content. They postulated that these trends were caused by the interlayer hydration of mica and its expansion to vermiculite. They also found that some of the vermiculite had further expanded to montmorillonite after about 4,500 yrs of postglacial weathering. Neither kaolinite nor gibbsite were detected.

Similarly Wang et al. (1986) speculated that the presence of vermiculite and smectite in late-Wisconsinan Podzolic soils in Nova Scotia could be attributed to the hydration and expansion of mica. It is known that the process of vermiculitization can occur rapidly ( $4000 \mathrm{yrs}$ ) in Podzolic soils (Protz et al.,1984) and is strongly influenced by texture and permeability (Protz et al., 1985). In addition to the appearance of secondary clay minerals in the Nova Scotia Podzolic soils, Wang et al. (1986) reported that chlorite was generally depleted in $A_{\theta}$ horizons, which suggests that groundwater percolation played a 
role in the removal of this mineral. They also noted that both mica expansion and chlorite destruction were more advanced on Podzolic soils which had developed on Shulie tills compared to those developed on the older Eatonville till in Nova Scotia and speculated that this anomaly could be attributed to the greater permeability of the younger soil.

\subsubsection{Alteration in Pre-Wisconsinan Canadian Soils}

Ross et al. (1984) also investigated a pre-Wisconsinan site on Mont Jacques Cartier (elev. 1,150m) on the Gaspé Peninsula, Quebec and preWisconsinan and "likely" pre-Pleistocene soils developed on saprolite on Big Bald Mountain (elev. 550-600m a.m.s.I.) in north central New Brunswick. The clay-size fraction of the Big Bald Mountain samples was found to contain a mixture of chlorite, vermiculite and mica. In heavily leached horizons, most of the mica and all of the chlorite had given way to montmorillonite and vermiculite. Significant amounts of gibbsite were found in subsoil horizons.

At the Mont Jacques Cartier site, Ross et al. (1984) found the only phyllosilicate in the clay-fraction present at a depth of $1.2 \mathrm{~m}$ was halloysite which gives way to kaolinite with increasing particle size. In the sand and silt fractions, the kaolinite was accompanied by interstratified biotite-vermiculite. Otherwise the mineral composition was similar to the clay-size fraction (Ross et al., 1983). Below a depth of $1.2 \mathrm{~m}$ the predominant clay mineral was found to be gibbsite (Ross et al. , 1984). Based on their work at both sites, Ross et al. (1984) concluded that that the presence of significant amounts of kaolinite and gibbsite in Canadian soils indicated pre-Wisconsinan weathering.

McKeague et al. (1983) investigated till and underlying saprolite exposed by a road cut in the Cape Breton Highlands. They argued that the saprolite is a pre-Wisconsinan weathering product which survived glacial erosion by virtue of the overriding glaciation being of the cold-based variety. This assumption was based in part on Sugden's (1977) model for North American Wisconsinan glaciation in which Sugden postulated a possible zone of cold-based ice in the 
ablation zone near the continental margin. McKeague et al. (1983) further maintained that Sugden's (1977) model was also consistent with the possibility that the Wisconsinan ice over the Cape Breton Highlands was in fact a local icecap.

The cut-bank is described in McKeague et al. (1983) as having 1-2m of saprolite formed from underlying granitic gneiss. The saprolite in turn underlies approximately $65 \mathrm{~cm}$ of till inferred to have been emplaced from the northwest. A 0-30 $\mathrm{cm}$ thick bed of reworked saprolite overlies this till. The reworked saprolite is in turn overlain by a second $1 \mathrm{~m}$ thick bed of soliflucted till similar in appearance to the lower till. These materials were analyzed using $\mathrm{X}$-ray diffraction analysis, infrared spectroscopy, differential thermal analysis, transmission electron microscopy, and SEM-EDXRA. McKeague et al. (1983) concluded that the feldspar and biotite in the saprolite had weathered to poorly crystalline kaolinite, gibbsite, and a minor component of iron oxide. The poorly crystalline kaolinite was found in moderate amounts in medium silt $(5-20 \mu \mathrm{m})$ and abundantly in the fine silt $(2-5 \mu \mathrm{m})$ to fine clay $(<0.2 \mu \mathrm{m})$ fractions. The gibbsite was found in trace amounts in the medium silt fraction, and in minor amounts in the fine clay fraction, but in quantifiable amounts in the intermediate $(5-0.2 \mu \mathrm{m})$ fraction. Dithionite-extractable $\mathrm{Fe}$ in whole samples ranged from 2.50$0.56 \%$, and oxalate-extractable $\mathrm{Fe}$ ranged from $0.42-0.16 \%$. The $\mathrm{X}$-ray powder diffraction patterns of altered grains of biotite were examined using a Gandalfi camera. A white powdery coating, found both on the surfaces and within the biotite flakes, was found to contain both gibbsite and disordered kaolinite. Thermogravimetric analysis for the bottom saprolite horizon indicated the coarse clay sample $(2-0.2 \mu \mathrm{m})$ contained $13 \%$ by weight of gibbsite and $39 \%$ by weight of kaolinite. The authors identified poorly crystalline kaolinite by a broad $7.3 \AA$ (for the (001) reflection) and $3.6 \AA$ peak (for the (002) reflection). They located the strongest reflection for gibbsite at $4.85 \AA$. 


\subsubsection{Alteration in the Central Yukon}

Foscolos et al. (1976) investigated soils and paleosols developed on preReid (early Pleistocene), Reid (Illinoian or early Wisconsinan) and McConnell (classical Wisconsinan) surfaces in the central Yukon. They noted a progressive decline in mica and a correlated increase in expandable clay minerals with age from McConnell to pre-Reid paleosols. Their evidence suggested two possible weathering sequences: from primary mica to depotassified mica to chlorite intergrades, and from primary mica to vermiculite to chlorite intergrades. They also found evidence that the depotassification of mica was accompanied by the adsorption of hydroxy-Al and hydroxy-Fe complexes.

\subsection{InVEstigative Methods}

The principal investigative tool of phyllosilicate alteration in the northwest Ruby Range fine-fraction was the Carleton University X-ray diffractometer, Philips Model PW 1730/1750, equipped with a copper anode and a scan range from 3 to $45^{\circ}$. In determining the relative mineral abundance, the details of which are reported in Chapter 5 , it was found that the mineral composition of the parent rock in Lithological Zone 2 (the igneous zone) was so variable that a meaningful study of the mineral depletion in the fine-fraction materials in that zone by comparison to the composition of the parent bedrock could not be attempted. For this reason, apart from a few initial samples, no $\mathrm{X}$-ray diffraction examination of the Lithological Zone 2 fines was carried out. When, subsequently, the phyllosilicate alteration study commenced, the question arose as to whether it would be cost-effective to undertake further $\mathrm{X}$-ray diffraction examination of Lithological Zone 2 samples solely for the purpose of identifying phyllosilicate alteration occurrences. It was decided that the extra cost could not be justified, and for this reason, the phyllosilicate alteration study has concentrated almost 
exclusively on fine-fraction samples from the schist zone. The two exceptions were the fine-fraction samples from sites $2 A 1$ and $2 A 6$ for which diffraction analysis had been conducted during the mineral depletion study.

The literature reviewed in the previous section entitled "Phyllosilicate Alteration in Selected Regions" indicates that, depending on the degree of weathering in the northwest Ruby Range study area, any or all of the following secondary minerals should be detectable in the fine-fraction samples: gibbsite, kaolinite, smectite, and vermiculite. The tests used to determine the presence of these minerals in the fine-fraction samples are described below. When identification was required, searches were carried out on the X-ray patterns of preferred orientation samples.

\subsubsection{Gibbsite Identification}

Gibbsite can be identified by its X-ray diffraction spacings without special chemical pre-treatment of the specimen. According to Brown and Brindley (1980), the $d(\AA)$ spacings for gibbsite are: $4.85,4.37,4.32$, and $2.45 \AA$. In samples in which the parent material is known to be a chlorite-quartz-micaplagioclase schist, a $4.85 \AA$ peak is diagnostic for gibbsite.

\subsubsection{Kaolinite Identification}

A positive identification of kaolinite in the presence of chlorite through $X$ ray diffraction without the additional aid of scanning electron microscopy (SEM) is difficult, and this latter resource was not available for this study. The first difficulty in positive identification is that the (002) reflection of chlorite roughly coincides with the (001) kaolinite reflection. Brown and Brindley (1980) give the (001) kaolinite spacing as $7.15 \AA$. As the $7 \AA$ reflections were normally very sharp, it was anticipated that a mixture of kaolinite and chlorite would produce a doublet which could be interpreted as evidence of the presence of kaolinite, and thus overcome the difficulty. 
The second difficulty in identifying kaolinite in the presence of chlorite is that the standard heat test produces ambiguous results. The standard diagnostic test for kaolinite is to heat the sample to $550^{\circ} \mathrm{C}$ for two hours. Under these conditions the (001) reflection at $7 \AA$ collapses. At the same time, however, the effect of the heating usually results in a structural rearrangement of chlorite in which the $14 \AA$ reflection is greatly enhanced at the expense of the second $(7 \AA)$, third, and fourth order reflections (Brown and Brindley, 1980). This makes it difficult if not impossible to determine if a partial collapse of the $7 \AA$ reflection is due to destruction of crystalline kaolinite, or if it is merely due to structural rearrangement of chlorite caused by the heating.

Under these circumstances, the only viable option left is to try to identify other distinctive kaolinite peaks. The other kaolinite peaks which should be identifiable are $4.44,4.36,2.56,2.29,1.662,1.619$, and $1.452 \AA$. In view of the mineral content of the parent material in this part of the study area, only the $4.44,4.36,1.619$, and $1.452 \AA$ could be considered as diagnostic for kaolinite and their identification would require randomly oriented mounts.

\subsubsection{Smectite Identification}

The literature review indicated that alteration of parent phyllosilicates to smectite was a possibility. To test for smectite, five fine-fraction samples (two from the igneous lithological zone and three from sites in the schist zone) were subjected to ethylene glycol solvation. In this test, the sample is suspended for 48 hours over an ethylene glycol bath and then, while still moist, is placed in the diffractometer. The presence of smectite is indicated by a new basal reflection at a spacing between 16.4 and $17.1 \AA$ (MacEwan and Wilson, 1980). 


\subsubsection{Vermiculite Identification}

The literature review also indicated that phyllosilicate alteration to vermiculite was a possibility. To test for this, samples from selected sites were given a potassium saturation pre-treatment according to the procedures outlined in Whittig and Allardice (1986). Enough $1 \mathrm{M} \mathrm{KCl}$ is added to an aliquot of dispersed suspension to ensure clay flocculation. The suspension is centrifuged and the supernatant solution is discarded. The sample is then washed four times (centrifugation and decantation) with $1 \mathrm{M} \mathrm{KCl}$ to complete the saturation. Excess salts are removed by washing once with $50 \%$ methanol, once with $95 \%$ methanol, and then with $95 \%$ acetone until the clear decantate gives a negative test for chloride with $\mathrm{AgNO}_{3}$. An oriented specimen is placed in the diffractometer while still in a moist condition. Vermiculites will collapse to essentially non-expanded structures $(10 \AA)$.

\subsection{RESULTS}

\subsubsection{Presence of Gibbsite and Kaolinite}

An examination was conducted of all the X-ray diffraction patterns of samples from the schist zone for evidence of the presence of gibbsite and/or kaolinite. In all these records, the gibbsite peaks at $4.85 \AA, 4.37 \AA$ and $4.32 \AA$ are missing. As for evidence of kaolinite, no double peaks in the vicinity of $7 \AA$ and $3.5 \AA$ were found. A precise measurement of the d-spacings of the peaks that are present reveals that they occur at 7.10 and $3.54 \AA$, respectively, which is more characteristic of chlorite than kaolinite (Brown and Brindley, 1980). In several instances, the $7 \AA$ peak partially collapses when the sample is heated to $550^{\circ} \mathrm{C}$, but as explained earlier, this is to be expected whenever chlorite is present (Brown and Brindley, 1980). Based on these observations, it is concluded that if weathering processes within the study area are producing either gibbsite or kaolinite, they are producing them in such minute quantities that their presence 
is undetectable by X-ray diffraction, even in a clay-rich sample such as that of Site1C1.

\subsubsection{Stacking Disorder}

The X-ray diffraction records indicate that some form of phyllosilicate stacking disorder has occurred in the fine-fraction materials in 69 of the 121 sites in the schist zone of the Ruby Range study area, including the sites on Transect $L$ in which the mica is of the biotite series. In the igneous zone, this disorder was found in 18 of the 25 fine-fraction records, but it was found in none of the whole rock records of either zone. In most instances, the disorder takes the form of a raised baseline or "plateau" between the 14 and $10 \AA$ reflections. The record from Site $1 \mathrm{~K} 4$ (Figure 4.1) is typical. In other instances a broad and diffuse, but nevertheless distinguishable, reflection appears within the boundaries of this "plateau" at roughly the $12 \AA$ spacing. The record from Site 1C4 (Figure 4.2) is typical of this pattern.

Grinding during sample preparation can artificially induce disorder which manifests itself in diffraction peak broadening and can often lead to complete destruction of the diffraction pattern. (Brindley and Brown, 1980) However, this is highly unlikely to be the cause for the observed disorders in the current study. These disorders are confined exclusively to fine-fraction samples despite the fact that the preparation of rock samples for $\mathrm{X}$-ray diffraction required even more vigorous and prolonged grinding, but did not produce any sign of this disorder. 


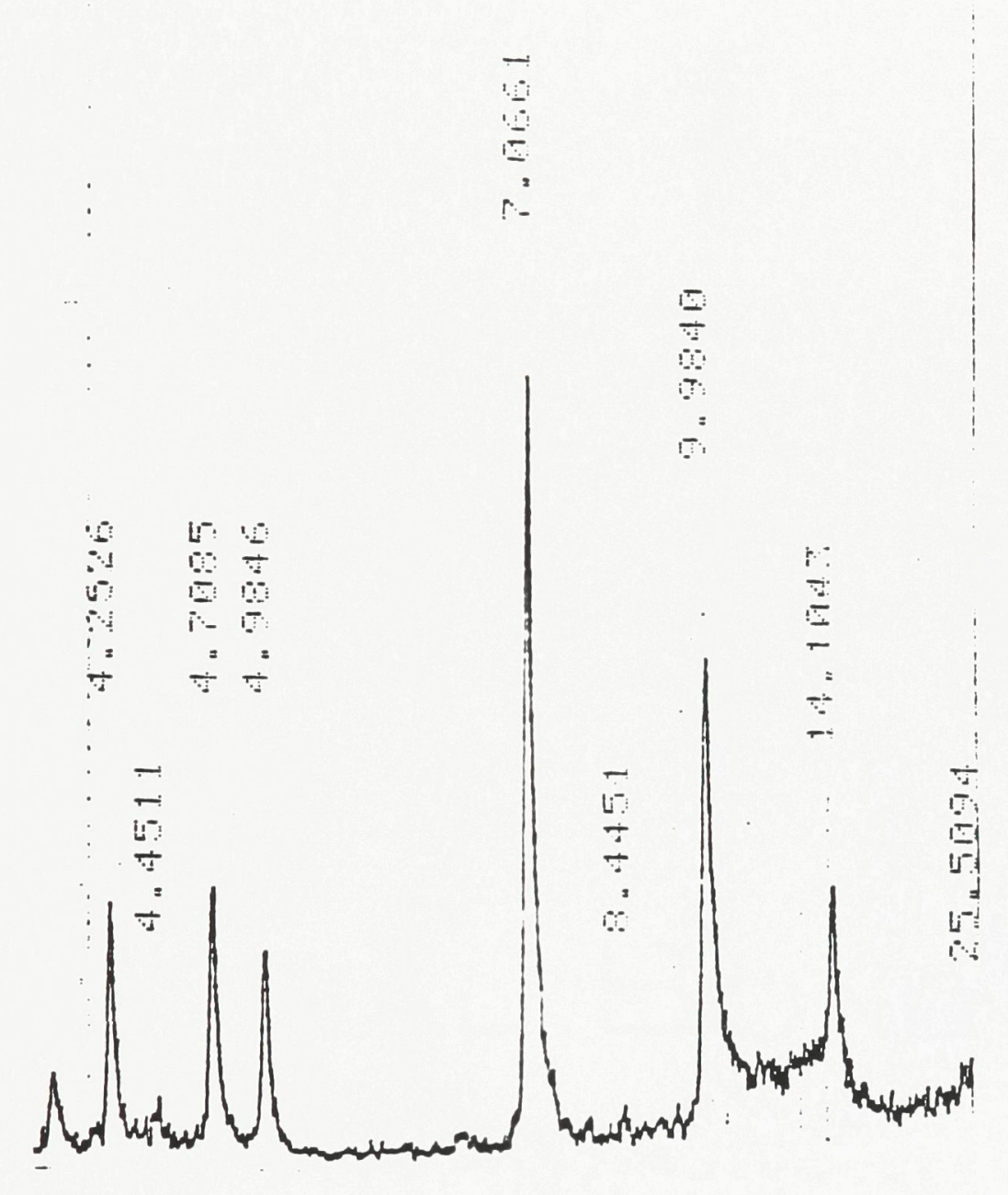

Figure 4.1: Example of a raised baseline or "plateau" between 10 and $14 \AA$ from the X-ray diffraction record of Site $1 \mathrm{~K} 4$. The vertically oriented numbers are $\alpha$-spacings in angstroms. 


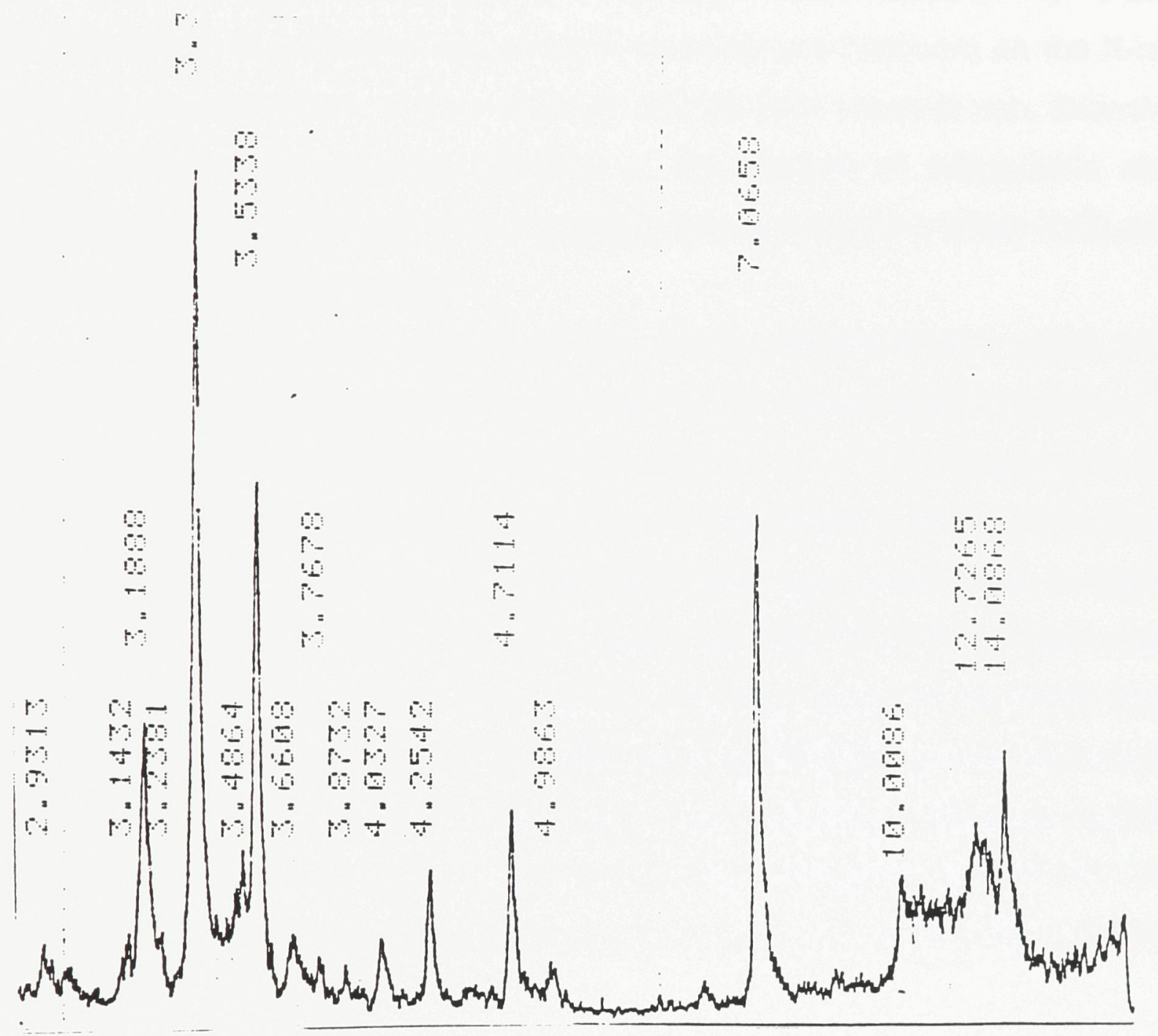

Figure 4.2: An example of a broad diffuse peak between 10 and $14 \AA$ from the X-ray diffraction record of Site $1 \mathrm{C4}$. 
In theory, the observed disorder could also have resulted from an overzealous application of the $\mathrm{H}_{2} \mathrm{O}_{2}$ pre-treatment of fine-fraction samples to remove organic matter. This would have resulted in some hydrolysis in the mica which would have manifested itself as a stacking disorder between the 10 and $14 \AA$ reflections. In a study of the effect of chemical pre-treatment on the X-ray diffraction characteristics of clay minerals derived from volcanic ash, Brewster (1980) observed an apparent increase in the amount of expandable clay minerals and concluded that it was probably due to hydrolysis when $\mathrm{H}_{2} \mathrm{O}_{2}$ was used to remove organic matter.

In this current study, $\mathrm{H}_{2} \mathrm{O}_{2}$ has been used to remove organic matter from all fine-fraction samples. However, the samples were pre-treated in batches, in which all samples in each batch received the same amount of $\mathrm{H}_{2} \mathrm{O}_{2}$ and were left to soak in it for the same amount of time. A subsequent check of the X-ray diffraction records revealed no instances where one batch had a higher incidence of disorder than any other when samples from one batch were compared to samples in another batch from the same region of the study area. Also, despite the fact that some batches were left to soak longer than other batches, many of the samples with the longest soaking times were subsequently found to contain no discernible evidence of disorder. All of this suggests that the disorder found in the other fine-fraction samples is unlikely to have been caused by the $\mathrm{H}_{2} \mathrm{O}_{2}$ pre-treatment .

If neither physical nor chemical preparation of the samples in the laboratory has caused this disorder, then it is reasonable to assume that the cause may be related to natural mineral weathering, and in fact phyllosilicate alteration is known to cause precisely the types of $X$-ray diffraction patterns that were produced by many of the study area fine-fraction samples. For instance, Mathieson and Walker (1954) demonstrated that K-saturated vermiculites produced a very broad peak between 10.5 and $14.3 \AA$ when submerged in water. Also MacEwan and Wilson (1980) observed that interlamellar complexes can show a mixture of a limited number of interlayer spacings, and sometimes, with 
an aqueous medium between the layers, a different type of complex can occur in which instead of a definite interlayer spacing there is a continuous distribution of interlayer distances. These patterns occur in several of the study area's finefraction samples, but in none of the rock samples.

In addition, Shroba's (1977) work on soil development in the southern and central Rocky Mountains indicated the presence of hydrobiotite. He reported that this hydrated mica sometimes manifests itself on $\mathrm{X}$-ray diffraction. This peak was unchanged by glycolation, but decreased to $10 \AA$ after heating to $550^{\circ} \mathrm{C}$ for $2 \mathrm{~h}$. Once again this pattern was observed in my study area samples.

In addition to these effects, it is known that, in the natural process of weathering, mixed-layer minerals result from the interstratification of $2: 1$ and 2:1:1 layer clay minerals. Birkeland (1984) maintained that this interstratification is possible because many of the clay minerals are structurally similar, and because some expand readily in water or upon slight weathering. To this, Reynolds (1980) added the observation that the interstratification pattern varies from a regular repetition of the components in the direction of the $c$-axis to a wholly random arrangement. According to Birkeland and Janda (1971) random interstratification of biotite with vermiculite or chlorite may account for peaks greater than $10.1 \AA$.

In view of all of the above observations, it was decided that a selected number of fine-fraction samples from the study area whose $X$-ray diffraction records displayed either the "plateau" pattern between the 10 and $14 \AA$ reflections or a broad diffuse reflection in the $12 \AA$ range, should be tested for the presence of smectite and vermiculite. For purposes of comparison, a sample from Site $1 A 7$, whose record displayed no signs of disorder, was also tested.

\subsubsection{Presence of Smectite}

The results of the testing by ethylene glycol solvation are shown in Table 4.2. 


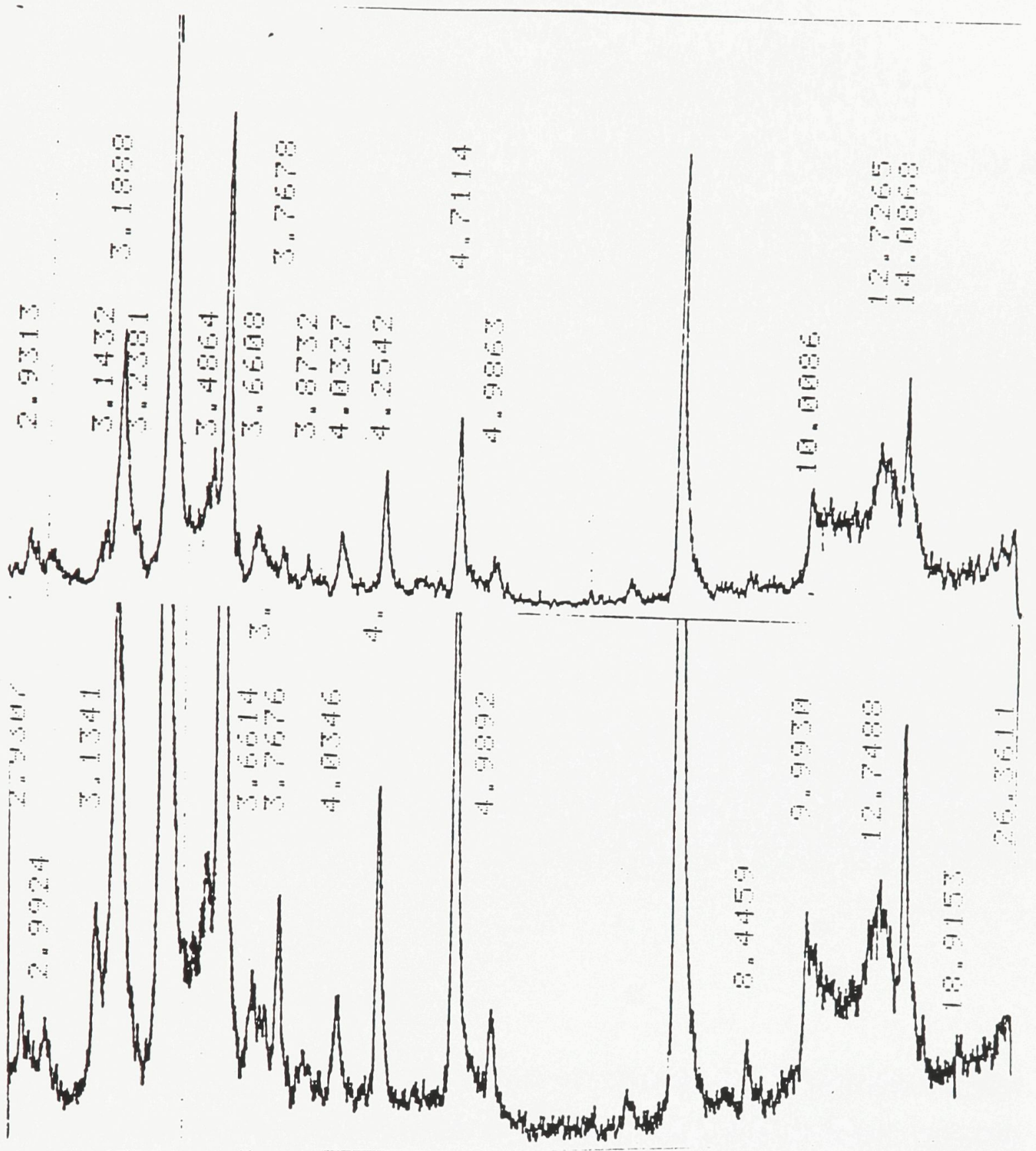

Figure 4.3: Effect of glycol solvation on sample from Site 1C4a. Top: Sample before solvation. Bottom: After solvation showing very small $18.92 \AA$ reflection which is barely discernible despite a $100 \%$ increase in the amplitude scale. 
Table 4.2: Ethylene Glycol Solvation Test Results

\begin{tabular}{|c|c|c|}
\hline Site & Results & $\underline{\text { Remarks }}$ \\
\hline $1 \mathrm{~A} 7$ & No reflection at $16-18 \AA$ & No disorder between 10 and $14 \AA$ \\
\hline $1 \mathrm{C} 4$ & $\begin{array}{l}\text { Very small peak at } 18.91 \AA \text {, but so small } \\
\text { that it could be background noise }\end{array}$ & Broad diffuse peak at $12 . .73 \AA$ \\
\hline G2 & No reflection at $16-18 \AA$ & $\begin{array}{l}\text { Disorder between } 10 \text { and } 14 \AA \text { but no } \\
\text { distinct peak }\end{array}$ \\
\hline 4 & $\begin{array}{l}\text { Very small peak at } 18.59 \AA \text {, but so small } \\
\text { that it could be background noise }\end{array}$ & Broad diffuse peak at $12.67 \AA$ \\
\hline & No reflection at $16-18 \AA$ & No disorder between 9 and $14 \AA$ \\
\hline
\end{tabular}

As can be seen from the above results, two of the five samples produce very small reflections at 18.59 and $18.92 \AA$ which could easily be nothing more than background noise, and these basal spacings are somewhat beyond the range of spacings that this test normally produces when either vermiculite (14.316.3A) or smectite (14-17.1) is present (MacEwan and Wilson, 1980). Nevertheless, it is of interest that at the same time, both samples produce broad diffuse peaks at 12.67 and $12.73 \mathrm{~A}$, which is indicative of phyllosilicate alteration. On balance, however, because the $18 \AA$ reflections are so small (see Figure 4.3), their appearance does not constitute adequate proof that smectites are being produced at these two sites, although other forms of alteration may be taking place.

\subsubsection{Presence of Vermiculite}

In order to test for the presence of vermiculite by K-saturation, finefraction samples from seven sites were selected to reflect the broadest possible range of conditions within the study area under which fine-fraction samples were found to exhibit some degree of disorder between the 10 and $14 \AA$ reflections. These 7 sites are listed in Table 4.3. In none of these K-saturated samples was any collapse noted in the disordered "plateau" formation between 10 and $14 \AA$. Nor was any collapse noted in the broad diffuse $12 \AA$ reflection which appears in the records of sites $1 \mathrm{C} 4$ and $2 \mathrm{~A} 1$. 
Table 4.3: Sites Selected for K-Saturation Testing

$\frac{\text { Site }}{1 \mathrm{~A} 8}$

$1 \mathrm{C} 4$

1D1

$1 \mathrm{H} 8$

$1 \mathrm{~K} 4$

$1 \mathrm{~L} 3$

$2 \mathrm{~A} 1$

\author{
Remarks \\ Relict glacial-margin meltwater channel \\ East-facing slope; distinct $12 \AA$ peak;
}

Base of permanent snow bank on north-facing slope Immediately below large relict sub-glacial meltwater channel

Base of schist tor in scree

North-facing slope; parent mica is biotite

Tarn lake sediment in the Lithological Zone 2 ; parent mica is biotite; distinct $12 \AA$

This absence of collapse was not unanticipated. Although Barshad (1948) determined that vermiculites will collapse to essentially non-expanded structures $(10 \AA)$ when saturated with $\mathrm{K}^{+}$whereas most chlorites will remain unaffected, subsequent work by Walker (1961) established that the structural contraction through K-saturation may be absent or only partial with low-charge vermiculites. In such cases, he found that a distinct $12.5 \AA$ spacing was possible or alternatively a broad intermediate spacing resulted, indicating interstratification of contracting and non-contracting forms.

Other work has demonstrated that randomly spaced hydroxy complexes in the interlayers are common in soil vermiculites and complicate the differentiation of those phyllosilicate species which produce a $14 \AA$ peak (Rich and Obenshain 1955; Tamura, 1955; and Klages and White, 1957). Today, according to Whittig and Allardice (1986), it is generally accepted that hydroxy interlayers ( $\mathrm{Al}, \mathrm{Fe}$, or $\mathrm{Mg}$ ) are common in soil vermiculite species, and these interlayers occur as randomly spaced islands between the phyllosilicate layers. The effect is to block the replacement by $\mathrm{K}$ cations, thereby allowing the vermiculite to retain its interlameller water despite K-saturation pre-treatment.

The question arises as to whether or not such hydroxy complexes exist in the Ruby Range study area fine-fraction materials. Work on soils of the central Yukon northeast of the Ruby Range by Foscolos et al. (1976) led them to conclude that one of the weathering sequences prevalent in the region involved the transformation of mica to depotassified mica accompanied by the adsorption 
of hydroxy complexes. It is a relatively short step from such a process to the process of interlamellar hydration of the depotassified mica to form a vermiculite species which resists any attempt to dehydrate it through potassium saturation.

To identify such non-contracting vermiculites, Whittig and Allardice (1986) recommend the heating of samples suspected of containing vermiculite with interlayer hydroxy complexes to $550^{\circ} \mathrm{C}$ for 2 hours. This will result in the collapse of the vermiculite, but will leave any chlorite in the sample unaffected. When all seven of the selected study area samples likewise failed to collapse following $\mathrm{K}$ saturation, the recommended heat treatment was applied and new X-ray diffraction records obtained. This time, with one exception, large but incomplete collapses of the disorder "plateau" formations between 10 and $14 \AA$ occurred. The records for Site $1 \mathrm{~K} 4$ (Figure 4.4) are typical. In the record for the sample from Site $1 \mathrm{C} 4$, which was one of the two samples in which a distinct $12 \AA$ reflection had appeared, it too underwent a large but incomplete collapse (see Figure 4.5).

However, in the second sample with a $12 \AA$ reflection, the sample from Site $2 \mathrm{~A} 1$, the $550^{\circ} \mathrm{C}$ pre-treatment resulted in a virtually complete collapse of the 14 and $7 \AA$ reflections and a complete collapse of the disorder formation between the 10 and $14 \AA$ reflections (see Figure 4.6). This was the only sample to display full collapse of the disorder formation, and Site $2 A 1$ is the only site from the Lithological Zone 2 whose sample received this heat treatment. It is a characteristic of the clastic parent material in the vicinity of Site $2 \mathrm{~A} 1$ that it contains very little chlorite. Therefore, the almost complete collapse of the 14 and $7 \AA$ reflections indicates that original 14 and $7 \AA$ reflections in the unheated sample were indicating the presence of vermiculite along with a trace amount of chlorite. The significance of this finding is that, in the Ruby Range fine-fraction, vermiculite can form from a phyllosilicate other than chlorite. In this case, the other phyllosilicate must by default be either biotite or possibly a biotitic-illite. In view of the structural similarity of both the biotite and muscovite series of mica, one would surmise that, in the muscovite-schist sites, at least some of 


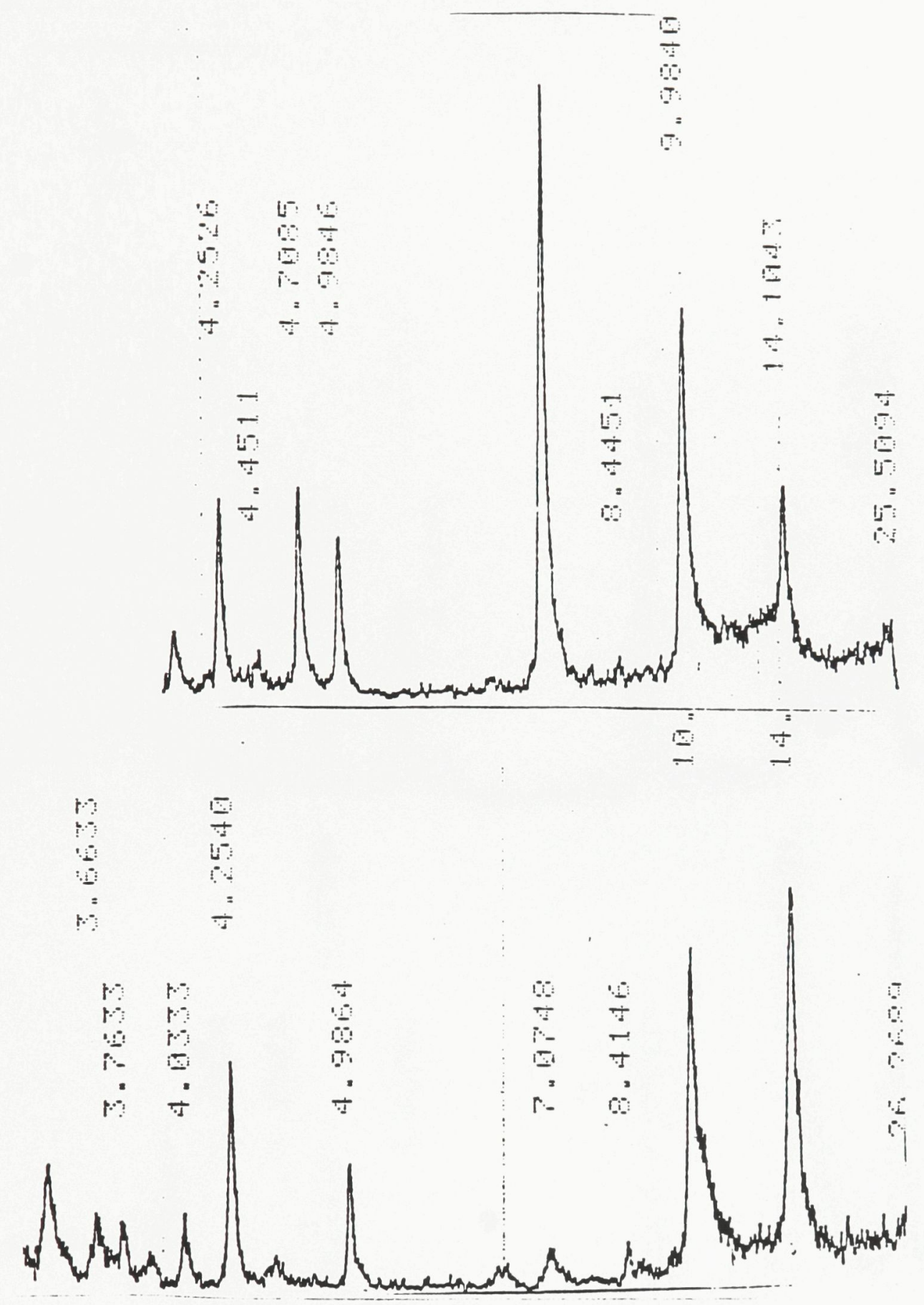

Figure 4.4: Partial collapse of "plateau" after heat treatment. Top: $\mathrm{K}$-saturated sample from Site $1 \mathrm{~K} 4$ before heating. Bottom: Same sample after heating for 2 hours at $550^{\circ} \mathrm{C}$. 

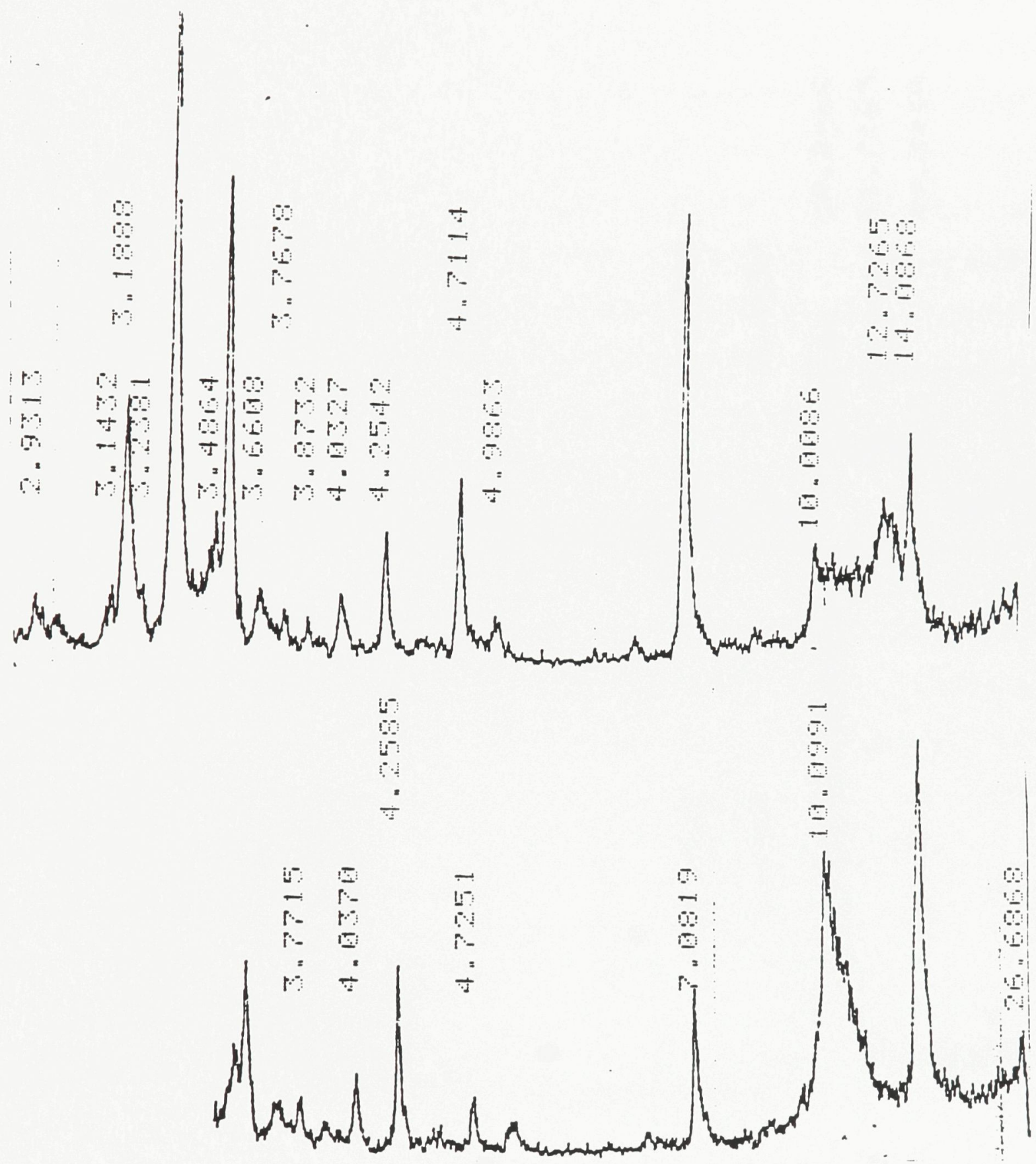

Figure 4.5: Collapse of $12 \AA$ reflection following heating.

Top: K-saturated sample from Site 1C4 before heating.

Bottom: Same sample after heating. 


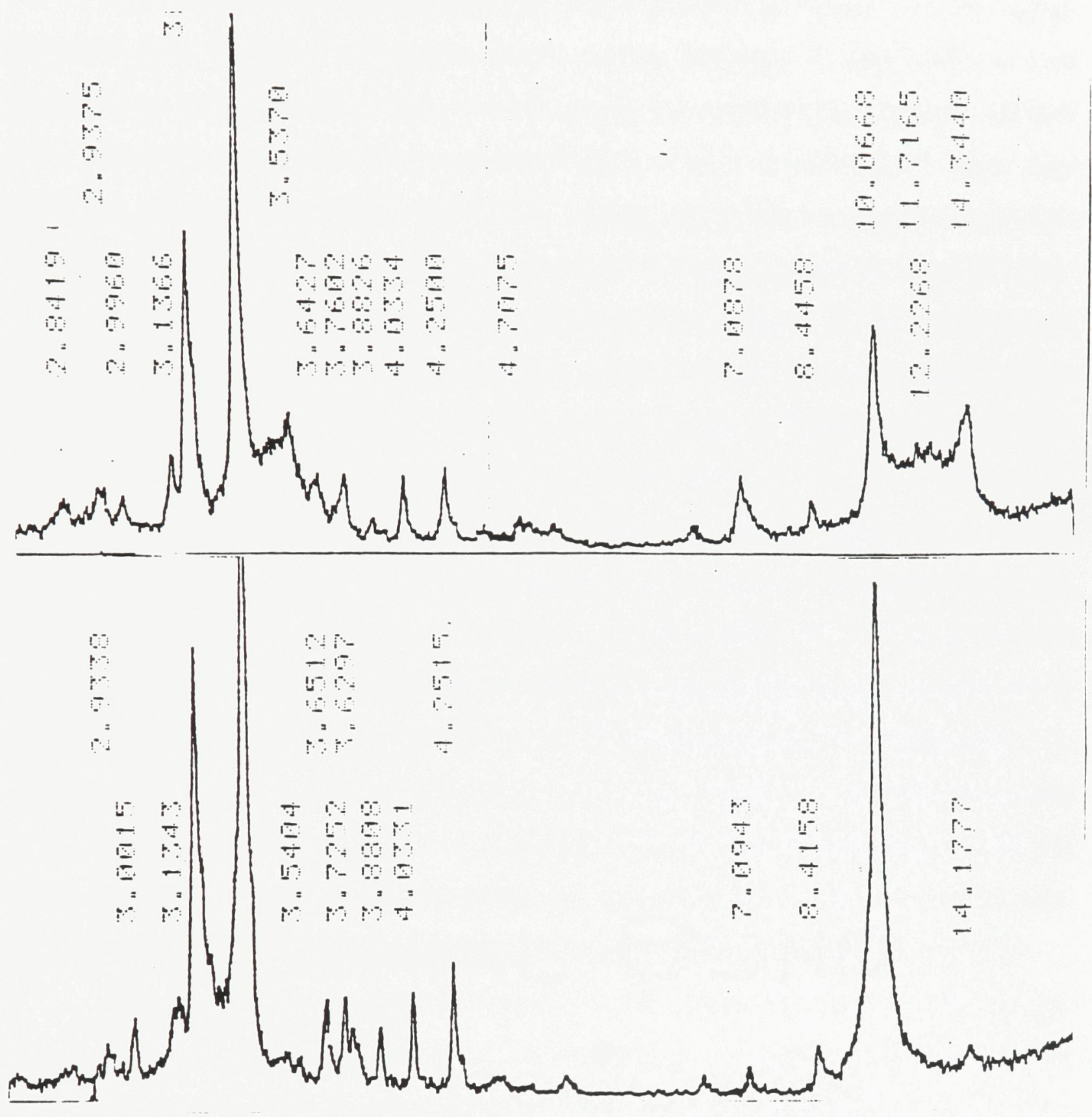

Figure 4.6: Effect of heat pre-treatment on a sample containing very little chlorite. Top: Untreated sample from Site 2A1. Bottom: Same sample after heating to $550^{\circ} \mathrm{C}$ for two hours. Note the collapse of the 14 and $7 \AA$ reflections as well as the total collapse of the disorder formation between them. 
the vermiculite detected in the samples must have formed from mica parent material as well.

The most likely explanation for the disorder formation in the other samples (the "plateau" formation which occurs between 7 and $14 \AA$ ) is that mixed-layer minerals also have formed during the weathering process. Mixedlayer minerals result from the interstratification of both $2: 1$ and 2:1:1 layer clay minerals. According to Reynolds (1980), mixing varies from a regular repetition of the components in the direction of the $c$-axis to a wholly random arrangement.

If this has happened in the Ruby Range fine-fraction, the 2:1 component in this case could be either mica or illite. Illite is known to be an early stage weathering by-product of both muscovite and biotite (Fieldes and Swindale, 1954). Illite, if it exists at all within the study area, would be undetectable through X-ray diffraction since the 001 reflection of both components would remain at $10 \AA$ regardless of the pre-treatment, and, hence, cannot be detected with the resources available to this study. As to a likely $2: 1: 1$ source for the creation of the mixed-layer minerals in the Ruby Range fine-fraction materials, it should be recalled that Foscolos et al. (1976) found that chlorite intergrades are a weathering by-product in central Yukon soils. A second 2:1:1 source candidate is, of course, vermiculite itself. It therefore follows that theoretically possible combinations of interstratified minerals are illite-chlorite, muscovite-vermiculite, biotite-vermiculite, chlorite-vermiculite, muscovite-chlorite, and biotite-chlorite.

The application of heat at $550^{\circ} \mathrm{C}$ for two hours should be sufficient to collapse all vermiculite. Therefore, all interstratified minerals in which vermiculite is a component would have collapsed to $10 \AA$ except for chlorite-vermiculite. The fact that the disorder formation persisted in all but the sample from Site 2A1 despite the vermiculite collapse is evidence that one, some, or all of the interstratified minerals in which chlorite is a component must be present. This confirms that chlorite is one of the parent materials from which mixed-layer minerals are formed in the study area. The reason that no disorder was 
observed in the sample from Site $2 \mathrm{~A} 1$ following this pre-treatment is that there is only a trace amount of chlorite in its parent material

In order to further identify the parentage of the mixed-layer minerals, and to further confirm the presence of vermiculite in the study area fines, a second heat test was conducted. Early work by Barshad (1948) with X-ray diffraction of heated vermiculites revealed that certain vermiculites when heated to $610^{\circ} \mathrm{C}$ would produce a collapse of the basal reflection to within a range of 9.4 to $9.6 \AA$ depending on the interlayer cations present. This occurred when the interlayer cations were $\mathrm{Mg}, \mathrm{Ca}$ and $\mathrm{Li}$, but it does not occur when they are either $\mathrm{Ba}$ or $\mathrm{K}$. Further to this, Walker (1956) reported that when all interlayer water is expelled, $\mathrm{Mg}$-vermiculite produces a basal reflection at $9.02 \AA$. Later work revealed that when heated to $700^{\circ} \mathrm{C}$, vermiculites produce a basal reflection in the same range at $9.3 \AA$ (Carroll, 1970).

Therefore, in view of the above findings, the two untreated samples which had produced the greatest disorder formations between 10 and $14 \AA$ (Site1C4 and $2 \mathrm{~A} 1$ ) were heated to $700^{\circ} \mathrm{C}$ for two hours without the K-saturation pretreatment (see Figure 4.7 and 4.8). In each case, it was found that the disorder formation had shifted to the $9-9.6 \AA$ range, and in the case of the sample from site $2 A 1$, a distinct reflection at $9.4 \AA$ was detected. These results confirm the presence of vermiculite in both samples.

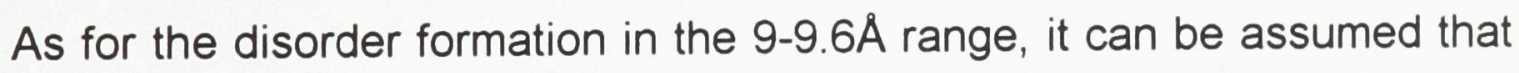
within this range of $d$-spacings, chlorite would play no role, and, furthermore, no micas will contract into this range. Therefore the disorder formation in this instance must be caused by the presence of randomly distributed vermiculitemica mixed-layer minerals which have produced a wide enough range of disorder to almost obscure the $9.4 \AA$ pure vermiculite reflection in the sample from Site $2 A 1$ and to totally obscure it in the sample from Site $1 \mathrm{C} 4$. 


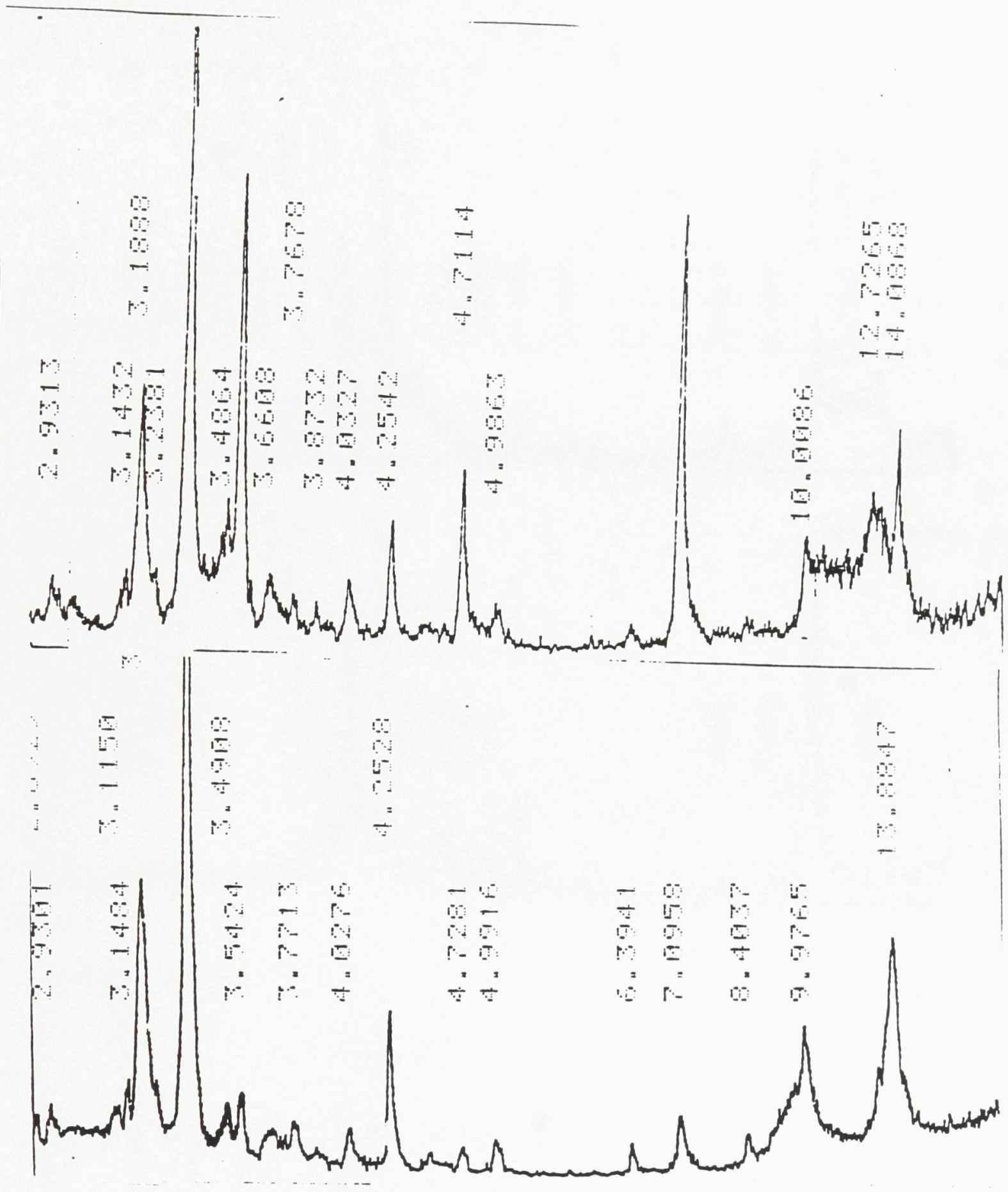

Figure 4.7: Sample from Site $1 \mathrm{C} 4$ heated to $700^{\circ} \mathrm{C}$ without K-saturation pre-treatment. Top: Before heating. Bottom: After heating. 

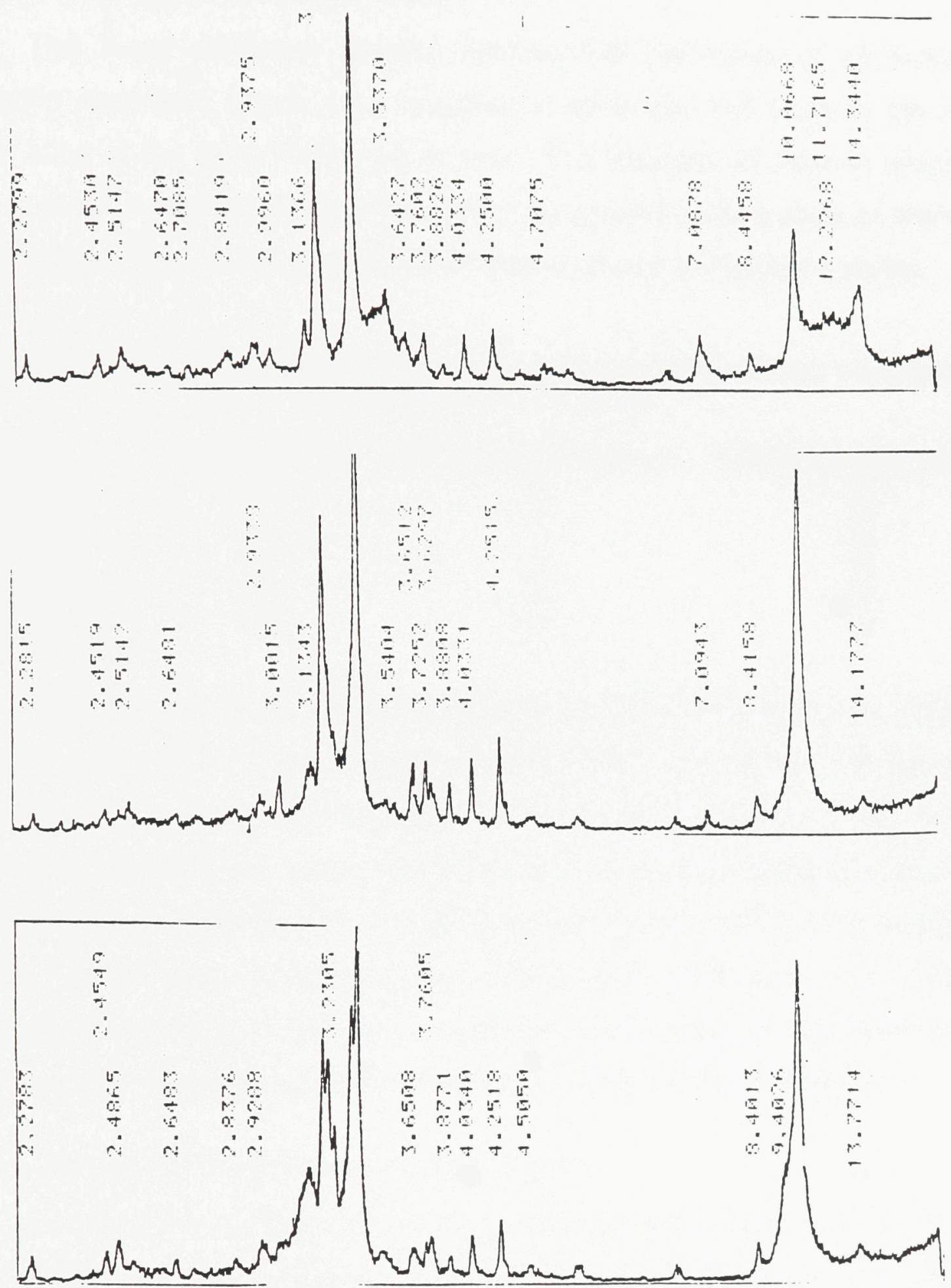

Figure 4.8: Effects of heat on sample from Site $2 \mathrm{~A} 1$ without $\mathrm{K}$-saturation pre-treatment. Top: Before heating. Center: After heating to $550^{\circ} \mathrm{C}$ for 2 hours. Bottom: After heating to $700^{\circ} \mathrm{C}$ for two hours. Note peak at $9.4 \AA$. 


\subsubsection{Distribution of Alteration Occurrences}

\subsubsection{Distribution by Glacial Zone}

The X-ray diffraction records indicate that the forms of phyllosilicate alteration described above have occurred in 69 of the 121 sites in the micaschist zone of the Ruby Range study area. This includes all sites in which the mica is of the biotite series. The distribution by ground surface zone of alteration occurrences in the 102 muscovite-schist sites is shown in Table 4.4 below.

Table 4.4: Distribution by Ground Surface Zone of Phyllosilicate Alteration Occurrences (Muscovite-Schist Sites Only)

\begin{tabular}{cccc} 
Zone & Number of Sites & Alteration Occurrences (n) & Alteration Occurrences (\%) \\
\cline { 2 - 3 } Pre-Nisling & 39 & 36 & 92 \\
Nisling & 27 & 8 & 30 \\
Ruby & 9 & 2 & 22 \\
St. Elias & 12 & 9 & 75 \\
Valley Bottom & 15 & 5 & 33 \\
Total & 102 & 60 & 59
\end{tabular}

As one would expect in a chronosequence, the Pre-Nisling sites, which lie on what is assumed to be the oldest surface, display the highest frequency of alteration occurrences (92\%). However, the next highest frequency $(75 \%)$ occurs on sites whose surfaces have been scoured by the most recent glacial event (the St. Elias). In contrast, the surfaces attributed to the older Nisling and Ruby glacials reveal much lower alteration frequencies. Therefore, if a useable chronosequence does in fact exist within the study area, its presence is not revealed in the frequency distribution pattern of phyllosilicate alteration.

\subsubsection{Alteration Frequency and Slope Aspect}

In view of the above finding, it was decided to investigate other factors which appeared to be correlated to the distribution of alteration occurrences. One of the most obvious of these was an apparent correlation between alteration frequency and slope aspect. The effects of slope aspect on soil temperature have been long known, and much of the useful work in this field had been 
carried out in Germany by the end of the nineteenth century. Wollny (1878) confirmed, with sand-filled boxes facing in eight separate directions and tilted at $15^{\circ}$, the long-held belief that the soil temperature tends to be highest on southwest facing slopes. Geiger (1966) summarized soil temperature data from field observations by Kerner (1891) which indicated that ground temperature at a depth of $70 \mathrm{~cm}$ tends to be higher on west, southwest, south, and southeastfacing slopes than it does on east, northeast, north, and northwest-facing slopes. Regardless of season, the warmest temperatures were recorded on southwestfacing slopes. The coldest temperatures were recorded on the north-facing slopes regardless of the season. The soil temperature distribution was found to be asymmetrical about the noon line. Geiger (1966) attributed this asymmetry to the differences between the application of forenoon and afternoon insolation. Much of the forenoon insolation, according to Geiger (1966), is used to dry surfaces on which it falls, while all afternoon insolation is used directly for heating the soil.

In more recent times, these findings by Wollny and Kerner have been confirmed by the work of N. Haarløv and B.B. Peterson in 1951, which is also reported in Geiger (1966). This research concerning the effect of aspect angle on both surface and sub-surface heating by insolation was conducted on a mature Sitka spruce stand in West Jutland. At a height of $1.3 \mathrm{~m}$ above ground, both surface bark temperature and inner trunk temperature at a depth of $5 \mathrm{~cm}$ were measured on each tree in the sample population by thermistors. They found that those parts of the trunk which received afternoon sun recorded the highest daily temperatures despite the fact that insolation was found to be symmetrical about the noon line. They attributed this anomaly to the fact that those parts of the trunks that received afternoon insolation were already drier as a result of forenoon warming which would reduce latent heat loss during subsequent direct insolation on these surfaces in the afternoon, thereby confirming the observations and the conclusions of Wollny and Kerner's earlier 
work concerning soil temperatures on hillslopes. This tendency for ground temperatures to be higher on hillslopes with aspects ranging from south to west combined with the desiccating effect of prevailing westerly winds in the study area makes a compelling case for the assumption that fine-fraction materials lying on south-, southwest-, and west-facing slopes should have appreciably lower soil-moisture content than slopes oriented in the opposite quadrants.

Within the schist zone of the Ruby Range study area, the distribution of sites with indications of phyllosilicate alteration is summarized in Table 4.5 below.

Table 4.5: Frequency of Alteration Occurrences by Slope Aspect

(Flat Ridge Top Sites Excluded)

$\begin{array}{ccccccccc}\text { Aspect } & \frac{\text { North- }}{n} & \underline{\text { North }} & \frac{\text { North- }}{\text { west }} & \text { East } & \underline{\text { South- }} & \text { South } & \underline{\underline{\text { South- }}} & \text { West } \\ \text { Frequency } & \frac{5 / 10}{\text { east }} & 8 / 10 & \frac{1}{3 / 4} & 10 / 10 & \frac{\underline{\text { east }}}{5 / 10} & 17 / 23 & \frac{\text { west }}{5 / 22} & 11 / 18 \\ (\%) & (50) & (80) & (75) & (100) & (50) & (74) & (23) & (61)\end{array}$

After excluding the southeast- and northwest-facing slopes which are on the boundary between high and low soil-moisture conditions, it can be seen that alteration is detectable in 21 of the 24 "low-evaporation" sites, (i.e., $88 \%$ ), but it is detectable in only 33 of the 62 "high-evaporation" sites, (i.e., 53\%). This indicates that soil-moisture content dictated by topographic factors (slope aspect and prevailing wind) is a significant factor in encouraging phyllosilicate alteration in the study area.

\subsubsection{Alteration Frequency and Dominant Vegetation Cover}

In order to investigate whether there is any meaningful correlation between alteration frequency and vegetation cover, all sites within the mica schist zone except for those within the floodplain were classified according to the dominant vegetation species on the site. The frequency of alteration occurrences is summarized in Table 4.6. The range of elevations within which each vegetation class is found is also shown. 
Table 4.6: Alteration Frequency by Dominant Vegetation Cover Class

\begin{tabular}{|c|c|c|c|c|c|}
\hline$\underline{\text { Cover Class }}$ & Felsenmeer & $\frac{\text { Tundra }}{\text { Shrub }}$ & Willow Bush & Aspen & Spruce \\
\hline Elevation Range (m) & $2320-1950$ & $2350-1190$ & $1770-1140$ & $1220-850$ & $1130-870$ \\
\hline $\begin{array}{c}\text { Frequency } \\
(\%)\end{array}$ & $\begin{array}{c}29 / 31 \\
(94)\end{array}$ & $\begin{array}{c}26 / 41 \\
(63)\end{array}$ & $\begin{array}{l}6 / 13 \\
(46)\end{array}$ & $\begin{array}{l}2 / 12 \\
(17)\end{array}$ & $\begin{array}{l}4 / 5 \\
(80)\end{array}$ \\
\hline
\end{tabular}

According to Lull (1964), the bulk of experimental evidence indicates that interception losses are generally greater beneath evergreen trees than beneath deciduous trees. It was therefore expected that aspen-covered sites would display a greater incidence of phyllosilicate alteration than spruce-covered sites, since the aspen-covered sites should have more soil-moisture content. In fact, the opposite occurs. Differing rates of precipitation do not appear to be the reason since the elevation range for both is virtually the same which eliminates orographic effect. In addition, there are no significant differences in the distribution of slope aspects between the two groups of sites, and hence that factor can be eliminated. Since neither of these two factors can explain the difference, it was decided to investigate whether differences in slope angle might provide an answer.

\subsubsection{Alteration Frequency and Slope Angle}

To determine if slope angle could explain the anomaly, within an elevation range of $1128-869 \mathrm{~m}$, the mean slope angle for all aspen-covered sites and the mean slope angle for all spruce-covered sites were calculated. The mean slope angle for the aspen-covered sites was found to be $23^{\circ}$, whereas it was only $6^{\circ}$ for the spruce-covered sites. A Student's $t$ test of the results indicated this difference was significant at the .005 level with 13 degrees of freedom on the basis of a one-tailed test.

To further investigate the possible effect of slope angle, the difference in mean slope angle between the 31 felsenmeer and 41 tundra-covered sites was 
examined. As Table 4.6 indicates, alteration occurred at $94 \%$ of the felsenmeer sites and $63 \%$ of the tundra-shrub sites. It was found that the mean slope angle for the felsenmeer group was $11^{\circ}$ compared to a mean slope angle of $14^{\circ}$ for the tundra-shrub group. A Student's $t$-test revealed that even this relatively small difference in mean slope angles was significant at the .06 level on the basis of a one-tailed test.

In view of the positive results of the previous two tests of the possible effect of slope angle, a third test was conducted, this time using all 102 muscovite-schist sites. The mean slope angle $\left(16^{\circ}\right)$ of all 35 non-alteration sites was tested for statistical significance against the mean slope angle for all 67 alteration sites $\left(12^{\circ}\right)$. The Student's $t$-test in this case indicated that the difference between the two groups is significant at the .02 level on the basis of a one-tailed test.

All three tests indicate that there is a close association between slope angle and frequency of phyllosilicate alteration. In Section 4.3.5.2, it was reported that a similar association occurs between frequency and slope aspect. Both slope aspect and slope angle have one characteristic in common - they both can have a controlling influence on soil moisture content. Since the alteration process in this case, vermiculitization, is one of hydration, it logically follows that factors which affect soil moisture content should display a close association with alteration frequency.

\subsection{CONCLUSIONS}

The work on phyllosilicate alteration clearly indicates that chemical weathering does take place in the northwest Ruby Range. However, this form of weathering appears to be confined to the production of secondary vermiculite as well as chlorite and vermiculite-based mixed-layer phyllosilicates of randomly interstratified composition. This is indicative of a very early stage of weathering. No indications of advanced weathering such as the presence of kaolinite or 
gibbsite were found. However, due to limitations on the resources available for this study, the possibility that trace amounts of these advanced secondary weathering products may have formed could not be ruled out.

The selected benchmark studies, especially those of Bockheim (1980), Evans and Cameron (1979), Shroba (1977), Dixon (1986), Ross et al. (1984), and Foscolos et al. (1976) indicate that the type of alteration which has been identified in the all ground surface zones of the study area could have developed as recently as the Holocene. Furthermore, the data on frequency of alteration occurrence as presented in Table 4.4 indicate no consistent trend to higher alteration frequency in older ground surface zones except for the differences in alteration frequency between the Pre-Nisling and the lower-elevation ground surface zones.

However, even in this case there are serious grounds for doubt in view of the anomalously high frequency observed in the St. Elias zone vis-à-vis the supposedly older Ruby and Nisling ground surface zones. In retrospect, the high alteration frequency in the Pre-Nisling zone may be attributable to some factor which was not monitored in the course of this study - uneven distribution of precipitation is one possibility. This leads to the conclusion that the phyllosilicate alteration phase of the study has produced no convincing evidence to support the chronosequence hypothesis.

On the other hand, elements of the data do support the toposequence hypothesis. The data presented in Table 4.5 on the frequency of alteration occurrences, when grouped according to slope aspect, indicate that the highest frequency occurs on those sites whose aspect favors high soil-moisture content. This indicates that slope aspect and its relationship to the prevailing wind is a significant factor in encouraging the type of phyllosilicate alteration found within the study area - namely that of vermiculitization.

In addition, three separate tests indicate that there is a close association between alteration frequency and slope angle in which sites with lower slope angles - and hence poorer drainage - display a higher alteration frequency. The 
data also indicate that vegetation cover per se may not be a factor. Although, Table 4.6 indicates that there are differences between the alteration frequencies of all the vegetation zones, tests of two of the largest differences indicate that they can also be explained by differences in the mean slope angles. In summary, two of the toposequence factors appear to have a close association with alteration frequency, and both these factors, namely slope aspect and slope angle, appear to affect phyllosilicate alteration through their influence on soilmoisture content. 


\section{RELATIVE MINERAL ABUNDANCE}

\subsection{INVEStigative Methods}

\subsubsection{General Approach}

One obvious method of assessing the temporal factor in chronosequences is to determine the extent of mineral depletion in the various components of the sequence. This can be accomplished from $\mathrm{X}$-ray diffraction records by comparing the relative abundance of the component minerals of the fine-fraction deposits to the relative abundance of the same minerals in the local bedrock using a methodology described in Section 5.1.5. Within the context of the ground surface zonation of the northwest Ruby Range as mapped by Muller (1967), one would anticipate that the fine-fraction deposits on the older surfaces would display, when compared to the assumed parent materials, a greater amount of mineral depletion than the fine-fraction deposits on more recent surfaces. Furthermore, the rates of depletion of the individual mineral components of the fine-fraction material should vary inversely to the relative weathering stability of those mineral components.

As guidance in such determinations, various weathering stability series have been proposed in earlier work. One of the earliest of these was published by Goldich (1938) for common rock-forming minerals based on their measured depletion rates in soils with respect to their relative abundance in their unweathered parent material. This series, modified somewhat by Keller (1954) 
and Hay (1959), is given below. The minerals are arranged in descending order of depletion rates. Biotite and sodium plagioclase are considered to have the same weathering rate.

\author{
$\mathrm{Ca}^{++}$-plagioclase \\ Olivine Fe-rich \\ Olivine Mg-rich \\ Hypersthene \\ Augite \\ Hornblende \\ Biotite and $\mathrm{Na}^{+}$-plagioclase \\ $\mathrm{K}^{+}$-feldspar \\ Muscovite \\ Quartz
}

Jackson et al. (1948) and Jackson and Sherman (1953) proposed a weathering sequence for the clay-size fraction of soils (repeated in an abridged form below). This sequence is also arranged in descending order of weathering rates.

1. Gypsum (also other salts)

2. Calcite

3. Olivine-hornblende

4. Biotite (also chlorite)

5. Albite (also orthoclase)

6. Quartz

7. Muscovite (also illite)

8. Interstratified 2:1 layer silicates and vermiculite (including partially expanded hydrous micas, randomly and regularly interstratified 2:1 layer silicates)

9. Montmorillonite

10. Kaolinite

11. Gibbsite

12. Hematite

13. Anatase 
Marshall (1977) maintained that this sequence is soundly based, and Ross et al. (1984) stated that it "is generally well suited to Canadian weathering conditions."

\subsubsection{Applicable Benchmarks}

There have been a number of studies conducted on rates of mineral depletion in fine-fraction materials under a range of conditions of climate and topography which encompass those found in the Ruby Range study area. From these studies, data were extracted to serve as benchmarks to assist in estimating the amount of time required to produce the degrees of depletion observed within the study area fines.

One such study was conducted by Ross et al. (1984) who found that, within the clay-size fraction of post-Wisconsinan chronosequences in the periglacial Hudson Bay coastal zone, both chlorite and quartz diminished with age. In montane environments, Shroba and Birkeland (1983) found mica more abundant above the tree-line than below it in soils of approximately the same (Holocene) age. In older soils formed in late-Pleistocene tills in the montane, semi-arid areas of the southern and central Rocky Mountains, they found that mica was appreciably more stable than chlorite. In fact, the chlorite was totally depleted in soils formed on the late-Pleistocene tills except in calcareous soils where the chlorite survived in soils as old as approximately 150,000 years. In the central Yukon, under conditions of climate and topography which are very similar to those of the study area, Foscolos et al. (1976) investigated soils and paleosols developed on pre-Reid (early Pleistocene), Reid (Illinoian or earlyWisconsinan) and McConnell (classical Wisconsinan) surfaces in the central Yukon. They found that neither chlorite nor vermiculite could be detected through $X$-ray diffraction of the clay-size fraction from any of these surfaces, although both could be found on more modern surfaces.

More detailed data have been published on mineral depletion in finefraction materials in Antarctica. The relative abundance of the clay minerals was 
estimated by measuring the height of the (001) X-ray diffraction peaks. Each peak height was divided by the total of all (001) peaks to give a percentage of the total peaks. It was found that the distribution of clay minerals does not change significantly with depth except that there is a slight reduction in mica and iron-rich chlorite at the surface. The distribution of surface minerals with age is shown in Table 5.1 below:

Table 5.1: Distribution of clay-fraction minerals in Eastern Wright Valley SOURCE: Bockheim (1979)

\begin{tabular}{ccc} 
Estimated Age (Y) & Mica (\%) & Fe-chlorite (\%) \\
\hline $1,400-3,900$ & $23-37$ & $18-22$ \\
18,000 & $1-17$ & $18-22$ \\
135,000 & $23-37$ & $18-22$ \\
$290,000-340,000$ & $1-17$ & $1-17$ \\
$800,000-920,000$ & $18-22$ & $23-37$
\end{tabular}

Other researchers warn that factors other than time alone influence rates of mineral depletion. Wang et al. (1986), for instance, found that chlorite was generally depleted in $A_{\theta}$ horizons in late-Wisconsinan Podzolic soils in Nova Scotia, and suggested that groundwater percolation had played a role in the removal of this mineral. This hypothesis gains further support from their observation that chlorite depletion was more advanced on the more permeable soils which had developed on Shulie tills than on those less permeable which developed on the older Eatonville till in Nova Scotia.

Further evidence that factors other than time alone influence depletion rates was provided when Wang and Ross (1989) conducted an investigation of saprolite and residual soils at five sites in the Appalachian Region of Atlantic Canada. The sites could be characterized as lying within a mid-latitude subalpine climate regime. Geomorphological evidence led these investigators to the conclusion that these sites certainly were pre-Wisconsinan, and, particularly as there was little or no evidence of glaciation, probably pre-dated the Pleistocene. The authors found that chlorite survived in the saprolites when it was known to be totally depleted in the $A_{e}$ horizons of post-Wisconsinan podzolic soils of the 
region. They hypothesized that pedogenic weathering takes place at a quicker pace than lithological weathering due to the abundance of biological acids and leaching available for pedological weathering and its relative scarcity in the lithological weathering process.

Of all the cases cited above, the findings of Foscolos et al. (1976) in the central Yukon provide the most applicable model for mineral depletion in the Ruby Range study area. The temperature and precipitation regimes in the two areas are similar. Mayo in the central Yukon, at an elevation of $504 \mathrm{~m}$, has a mean annual temperature of $-4^{\circ} \mathrm{C}$ and averages $306 \mathrm{~mm}$ of precipitation whereas Burwash Landing (689m elevation). within $20 \mathrm{~km}$ of the Ruby Range study area, has a mean annual temperature of $-6^{\circ} \mathrm{C}$ and $284 \mathrm{~mm}$ of precipitation (Chapter Two). Chlorite was found by Foscolos et al. (1976) to be undetectable in the preHolocene clay-size fraction $(\phi<0.002 \mathrm{~mm})$. As this is the fraction in which one would normally expect to find the greatest concentration of chlorite relative to all other minerals, it follows that chlorite would also be undetectable in the soil-size fraction $(\phi<2 \mathrm{~mm})$ of pre-Holocene fines. Therefore, one concludes that Holocene dating could be reasonably ascribed to any study area fines found to contain detectable amounts of chlorite in the soil-size fraction. One exception to the foregoing is the finding by Shroba and Birkeland (1983) that chlorite survives in pre-Holocene calcareous fines. However, calcite is absent from all Lithological Zone 1 fines except for a limited number of sites in the Post-glacial Ground Surface Zone.

The discovery by Bockheim (1979) of abundant chlorite in soils developed on tills as old as approximately 920,000 years in the Wright Valley, Antarctica would, at first glance, seem to contradict the findings of Foscolos et al. (1976), however, the survivability of chlorite in such ancient soils can be attributed to the extreme harshness of the Antarctic temperature and precipitation regimes. On the other hand, the work by Ross et al. (1984) in the Hudson Bay coastal zone tends to support the proposition that the presence of chlorite in the study area 
fines would indicate Holocene dating. The results reported by Wang et al. (1986) indicate that factors other than time can accelerate the rate of chlorite depletion, but there is nothing in the literature surveyed which suggests that the process can be retarded in non-calcareous fines other than under climate conditions as severe as those which prevail in the Antarctic. On balance, it would appear that the presence of chlorite in study area fine-fraction should generally indicate Holocene dating. An obvious exception to this, would be the case in which freshly-weathered fines are being continually added to older fine-fraction deposits - a situation envisaged in the additional materials hypothesis.

\subsubsection{Sample Preparation for X-ray Diffraction}

For the purposes of X-ray diffraction analysis, the oriented aggregate method of slide preparation was chosen. The relative advantages of randompowder and oriented aggregate specimens in X-ray diffraction analysis are summarized in Whittig and Allardice (1986). One advantage of the randompowder specimen is that, since the crystals lie in all possible positions with respect to the scanning ray, it is possible to obtain all the diffraction spacings from the minerals present. This materially assists in mineral identification since the complete family of diffraction maxima are obtained for each of the components of the mineral mixture. As these authors point out, more accurate quantitative estimates of mineral composition are possible since the relative intensities of diffraction maxima recorded from random-powder specimens are more nearly proportional to the numbers of crystals present than are the maxima obtained from an oriented specimen. This is important in quantitative estimates of the relative abundance of tabular crystals such as chlorite and especially when dealing with sheet minerals such as the mica group. Both these minerals tend to orient themselves in the (001) position, and hence any quantitative estimate based on oriented aggregate specimens will inevitably overstate the abundance of such minerals vis-à-vis minerals of other crystal shapes such as quartz or feldspar. 
On the other hand, the enhancement of (001) basal maxima in oriented specimens, according to these authors, often allows small quantities of phyllosilicate species to be detected when they might otherwise be obscured among more dominant species in the specimen. Using such a mount, detection of as little as one percent smectite in multi-component mixtures has been reported (MacEwan, 1946). The oriented mount has also been found to be advantageous when critically examining basal spacings since minor variations are more readily detected (Whittig and Allardice, 1986). On balance it was considered that oriented aggregate mounts would best serve the purposes of this study.

From the outset it was appreciated that identification of phyllosilicate species and even individual phyllosilicate series were critical to the outcome. Normally the masking effect of non-phyllosilicates can be reduced by extracting the clay-size fraction for detailed analysis, since the relative resistance to weathering of such minerals leaves them largely concentrated in the sand- and silt-sized fractions. The initial examination of fine-fraction samples indicated that they possessed very little clay-sized material, and this would be extremely difficult to separate from the whole sample. There was therefore no practical way of reducing the masking effect of such minerals as quartz and feldspar which inhibit phyllosilicate identification in multi-component whole-sample mixtures. Under such circumstances, the oriented mount which exaggerates phyllosilicate basal maxima is clearly advantageous.

The one clear disadvantage of this choice for the purposes of this study is that it reduces the capability of producing quantitative analysis because oriented-aggregate specimens tend to overstate phyllosilicate abundance, particularly with respect to the mica group. According to Whittig and Allardice (1986), the relative intensities of diffraction maxima theoretically provide a basis for estimation of concentrations of mineral species present. However, the practical limitations of $\mathrm{X}$-ray diffraction in quantitative analysis are widely accepted and are covered in detail in Jackson (1969), Barnhisel (1977), and 
Klages and Hopper (1982). In essence these authors maintain that in addition to concentration of species, diffraction intensities are affected by differences in particle size, crystal perfection, chemical composition, variations in sample packing, crystal orientation, and the presence of amorphous substances. These complicating factors led Whittig and Allardice (1986) to state that "Unfortunately, difficulties in controlling all ameliorating factors in many cases preclude acceptance at this time of a standard, generally applicable method for quantitative estimation of minerals from $\mathrm{X}$-ray diffraction analysis".

In view of all of the above limitations on quantitative analysis, regardless of the type of mount selected, it was considered that the extra resources required to produce random-powder specimens could not be justified when the end result would be no better than a slightly improved rough estimate. In any case, the major requirement in this study for quantitative analysis lies in determining the amount of mineral depletion that occurs in the process of transformation of a parent bedrock material to weathered fine-fraction. In such cases, we are examining relative mineral abundance in a pair of samples of very closely related mineral compositions. In these circumstances, reliable quantitative estimates of mineral depletion should be possible simply by comparing the intensity of the corresponding reflections in each of the two samples, and for this purpose, oriented-aggregate specimens should suffice.

In order to prepare oriented-aggregate specimens for $\mathrm{X}$-ray diffraction analysis, a $50 \mathrm{~g}$ sample was taken from that portion of the fine-fraction field sample which had been passed through a $2 \mathrm{~mm}$ sieve. The $50 \mathrm{~g}$ sample was placed in a $300 \mathrm{~mL}$ beaker to which approximately $200 \mathrm{~mL}$ of $3 \%$ hydrogen peroxide solution were added. Oxidation of the organic matter was allowed to continue until all frothing ceased. The beaker of fine-fraction material was then heated to $80^{\circ} \mathrm{C}$ and allowed to stand on the hot plate until all frothing had once again ceased. The beaker was then placed in an oven pre-heated to $105^{\circ} \mathrm{C}$ until all the liquid had evaporated. 
The residue was ground with mortar and pestle under ethanol to fine-sand texture. The resulting slurry was transferred by eyedropper to glass microscope slides and allowed to dry as a thin film. The use of ethanol departs from the customary practice of using water. This innovation was undertaken on the advice of Burn (1994, personal communication) who maintains an ethanol slurry will form a thinner film than a water-based slurry. Each mounted specimen was then checked under an optical microscope for consistency, and the best pair of specimens from each sample was selected for $\mathrm{X}$-ray diffraction.

The same pre-treatment procedures were used on rock specimen samples with three exceptions. The need for sieving is obviously eliminated as is the hydrogen peroxide pre-treatment to remove organic matter. The third exception was that only one specimen per sample was selected for $\mathrm{X}$-ray diffraction following optical microscopy.

\subsubsection{Verification of Parent-Material Composition}

As a prerequisite to a valid determination of rates of mineral depletion in the study area fine-fraction, it was necessary to verify the bedrock mineral assemblages of the various geological map units as originally described by Muller (1967, Map 1177a), and subsequently modified by the author in this study (Chapter Three). Lithological Zone 1 (see Map 3.1) is a zone of schistose materials encompassing two of Muller's geological map units. The southernmost of these units is described by Muller as "Pre-Mesozoic (mainly) quartz-sericitechlorite schist with minor quartzite". X-ray diffraction analysis of the rock samples taken from this unit (as described in Section 5.2) indicated that all the sericite was of the muscovite species. The material from second map unit of Lithological Zone 1, which lies in a belt northeast of the first, is described by Muller as "quartz-biotite-schist, in places carrying garnet; quartz-feldspar-biotite gneiss; amphibolite; and minor re-crystallized limestone". Sampling within this unit by the author confirms the presence of the schist, the amphibolite, and the 
recrystallized limestone, but not the quartz-feldspar-biotite gneiss. However, within the first map unit, one site was found to have an outcropping of quartzfeldspar-muscovite gneiss. Analysis also revealed the presence of a small amount of chlorite in schist from the second map unit described by Muller as "quartz-biotite schist".

Lithological Zone 2, on the other hand is a zone of Mesozoic and possibly Cenozoic rocks encompassing two of Muller's geological map units (see Map3.4). The western portion of Zone 2 consists of rocks of the Ruby Range Batholith which are reported to contain biotite-hornblende granodiorite, quartz monzonite, quartz diorite, and minor granodiorite gneiss. The northeastern portion of this zone consists of rocks of the Nisling Range Alaskite containing alaskite, granite, quartz monzonite, and minor rhylolite (Muller, 1967). Analysis of Zone 2 bedrock samples confirmed his description.

\subsubsection{Quantitative Measurement}

Although the identification of mineral species through $X$-ray diffraction $\alpha$ spacings is a universally accepted practice, determination of mineral abundance through the measurement of diffraction maxima intensities is not nearly as straightforward. The theory of quantitative estimation of mineral abundance through $X$-ray diffraction is based on the premise that 'the intensities of diffraction maxima are related to the number of corresponding diffraction planes in a sample... [, and] thus the relative intensities of maxima theoretically provide a basis for estimation of concentrations of mineral species present" (Whittig and Allardice, 1986). However, a number of factors can influence diffraction intensities in addition to mineral concentration. According to Jackson (1969), diffraction intensity is also affected by particle size, crystal perfection, chemical composition, variations in sample packing, crystal orientation, and presence of amorphous substances. 
In the current study there is a requirement for some degree of quantification of the relative changes in mineral abundance that occur as parent material weathers to fine-fraction deposits. Except in cases of extreme weathering, these changes are normally relatively small, and, as a consequence of this, differences in the degree of crystal perfection and in chemical composition could be expected to have a more noticeable effect on the intensity of individual diffraction peaks. Fortunately, these differences are usually readily identifiable, as these differences normally manifest themselves as well in alterations to the $d$-spacing and shape of individual peaks, and in the relative intensities of the family of peaks associated with a particular mineral. Once identified, such deviations can be compensated for by altering the method by which total peak intensity is calculated. Brown and Brindley (1980) provide useful data with respect to $d$-spacing and relative intensity alteration due to changes in chemical composition.

The presence of amorphous substances also should not be a significant factor since organic matter, a major component of such substances, was removed by hydrogen peroxide pre-treatment from all fine-fraction samples. A second class of amorphous materials, volcanic glass, in contrast to the organic matter, was found through optical microscopy to be a relatively minor component in the fine-fraction samples, and it was not considered likely to compromise the determination of depletion rates for phyllosilicates. However, as explained later in this chapter, precautionary measures were adopted for dealing with its possible effect on quartz normalization and determination of the relative abundance of feldspar. In addition, as the data in Chapter 6 indicates, iron oxides are a third class of substances whose presence in fine-fraction samples was anticipated. In this case, subsequent testing indicated that dithioniteextractable iron amounted to less than three percent of the total sample in almost all cases. This amount was considered to be insufficient to compromise the relative mineral abundance study. $\mathrm{X}$-ray diffraction examination of randomly 
selected samples, both before and after dithionite extraction, revealed no detectable difference in relative mineral abundance.

In addition, potential problems relating to those factors which arise directly from X-ray diffraction slide preparation (particle size, packing, and crystal orientation) were also investigated. In order to determine the magnitude of the problems, X-ray diffraction records were made from pairs of slides from each of the fourteen fine-fraction samples collected during the initial field season on Transect $1 \mathrm{~A}$. The intensity of each clearly identifiable reflection was estimated in accordance with the procedure outlined in Berry (1987). The vertical distance from the baseline to the reflection peak was measured to the nearest millimeter and multiplied by the measured width of the peak at the halfway point. This estimate of the cross-sectional area of the recorded reflection peak was in turn multiplied by the factor calculated from the scale of the diffraction record to determine the total diffraction intensity for that particular peak, expressed in counts per second. This calculation of the reflection intensity from the record of the first slide of each pair was then compared to the similarly calculated intensity of the corresponding reflection on the record of the second slide. In theory there should have been no differences in calculated intensity between pairs of corresponding reflections, but in fact most pairs of reflections did yield differing calculated intensities. In all, 406 pairs of reflections were calculated on the 28 diffraction records. The mean difference between the calculated intensity of the pairs of corresponding reflections was found to be $23 \%$ with a standard deviation of $22 \%$. These data yield a coefficient of variation of $92 \%$ indicating that these discrepancies were significant, and that additional measures would be required to eliminate them.

One method of nullifying these errors is to use an internal standard as described by Brindley (1980). This method involves adding a known weight of an internal standard mineral not already present in the sample. This modified sample is then designated as the standard mixture. For this mixture, the diffraction intensity ratios of the internal standard mineral to each of the mixture 
of the other mineral components are calculated and used to determine the weight ratio of the various component minerals to the internal standard mineral in each of the other samples. The difficulty with this procedure is that the process of weighing out and thoroughly mixing the materials is prohibitively timeconsuming for large sample batches. Related procedures in which a comparison is made of diffraction intensities in a sample to those of an artificial standard mixture composed of the same minerals as described by Willis et al. (1948), Talvenheimo and White (1952), and Berry (1987) are relatively accurate but equally time-consuming when dealing with large batches.

Fortunately, the requirement for quantitative measurement in this study is for the purpose of estimating mineral depletion in the fine-fraction relative to the parent material, and therefore the estimation of absolute mineral abundance, which the foregoing procedures would produce, is unnecessary. For estimation of relative mineral abundance, standards are available which produce far less time-consuming quantitative estimations. The most widely accepted method of standardizing (or "normalizing") samples for relative (or "semi-quantitative") compositional analysis is to use one of the component minerals already present in the sample as the internal standard.

The mineral most commonly used in this fashion is quartz which, according to Marshall (1977), can be used as a stable component in mineral weathering depletion studies because of the high resistance of quartz to weathering. The procedure employed is to divide the diffraction maxima of each of the other component minerals of a sample by the diagnostic $4.26 \AA$ diffraction peak of the quartz component of that particular sample. In this way, the diffraction peaks of the non-quartz components of the sample are converted to ratios which represent their relative abundance within the sample with respect to the quartz component of that sample. Once this procedure is applied to all samples in a given batch, these ratios can be used to estimate the degree of depletion which has occurred in each of the non-quartz components of the samples. 
Although both quick and simple, quartz normalization is by no means problem-free. The first and most obvious problem is that not all samples can be expected to have a quartz component. In the study area, one of the relatively minor but nevertheless widespread parent materials that contributes to the total fine-fraction is the White River volcanic ash (see Figure 5.1) which contains no quartz (Howes, 1991).

The second problem is that, even when there is a quartz component in the parent material, the implicit assumption behind the quartz normalization procedure is that the quartz component is constant throughout the parent material. Once again, within the confines of this study area, this condition was not met. Within the southern portion of the study area, the predominant parent material was found to be muscovite-bearing schist bedrock. A randomly selected group of 14 samples were examined for component mineral variability. The degree of variability of each mineral, expressed as a coefficient of variation $\left(\frac{\delta}{\bar{X}} \times 100\right)$ is summarized in Table 5.2 :

Table 5.2: Indicated coefficient of variation $(\%)$ in muscovite-bearing schist bedrock

\begin{tabular}{|c|c|c|c|c|}
\hline $\begin{array}{l}\text { Normalization } \\
\text { Method } \Rightarrow\end{array}$ & None & $4.26 A$ & $\begin{array}{l}\text { All-Peak } \\
\text { Average. }\end{array}$ & $\begin{array}{l}\text { Selected } \\
\text { 12-Peak } \\
\text { Average }\end{array}$ \\
\hline \multicolumn{5}{|l|}{ Component } \\
\hline \multicolumn{5}{|l|}{$\begin{array}{c}\text { Mineral } \Downarrow \\
\text { Chlorite }\end{array}$} \\
\hline $14 \AA$ & 31 & 49 & 22 & 19 \\
\hline $7 \AA$ & 31 & 46 & 22 & 17 \\
\hline \multicolumn{5}{|l|}{ Muscovite } \\
\hline $10 \AA$ & 45 & 53 & 41 & 40 \\
\hline $5 \AA$ & 49 & 41 & 41 & 39 \\
\hline \multicolumn{5}{|l|}{ Feldspar } \\
\hline $3.19 \AA$ & 60 & 72 & 59 & 54 \\
\hline Quartz & & & & \\
\hline $4.26 \AA$ & 35 & N/A & 30 & 28 \\
\hline
\end{tabular}




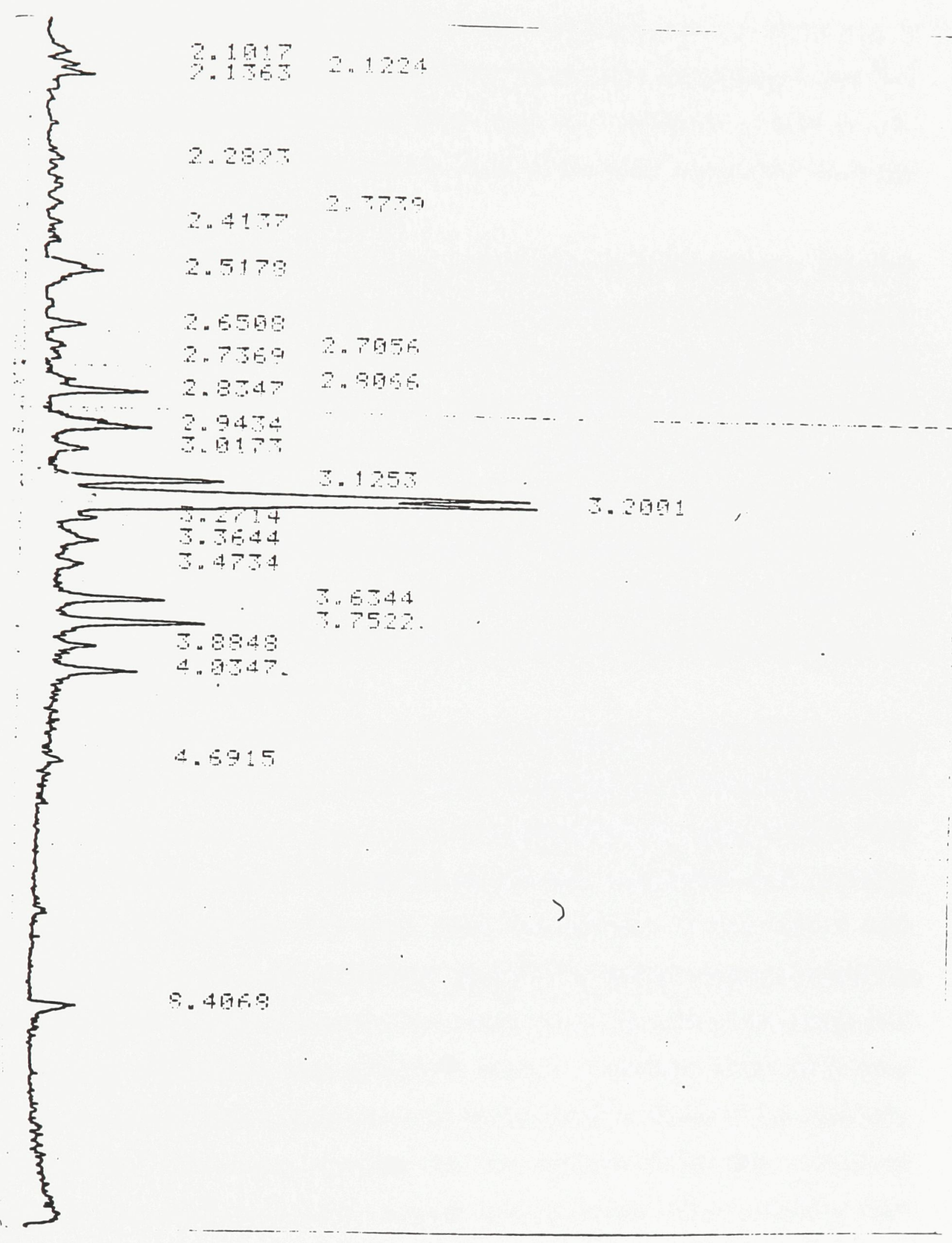

Figure 5.1: X-ray diffraction record of a sample of White River volcanic ash. Note the absence of a diagnostic quartz reflection at $4.26 \AA$. The curved baseline indicates the predominance of amorphous material - in this case, volcanic glass. The principal minerals present are amphibole $(8.41,4.03,3.88$, and $2.83 \AA)$ and feldspar $(3.75,3.63,3.20$, $3.13 \AA)$ with some magnetite $(2.94$ and $2.52 \AA)$. 
This indicates that the quartz content of the muscovite-bearing schist has a coefficient of variation ranging from 28 to 35 percent depending upon the method of normalization/non-normalization used. This variability inhibits its use as a normalizing standard. Unfortunately, none of the other component minerals displays significantly lower variability.

To resolve this difficulty, two new approaches were considered. The first of these adopts the mean calculated intensity of all the reflection peaks that can be identified as such from the diffraction record as the normalization standard ("the all-peak average" in Table 5.2). In theory, adoption of this method should eliminate distortions created by quantitative variability in any single mineral which might otherwise be employed as the normalization standard. In practice, however, this did not prove to be entirely true. The approach was tried on the same 14 muscovite-bearing schist samples, and the results (see Table 5.2) indicated that compositional variability of the component minerals decreases, but not by as much as was expected.

The most likely explanation for this can be seen from the data in Table 5.3. These data summarize the results of an investigation of the distribution of diffracted $X$-ray energy from one typical muscovite-bearing schist sample. The intensity of all 32 readily discernible peaks was calculated and grouped according to the minerals that each peak represented. In this way it was determined that, in an X-ray diffraction record of a typical muscovite-bearing schist sample, the quartz component dominates producing $44 \%$ of the peaks and accounting for $49 \%$ of the total diffraction energy. Therefore, when used as a normalizing standard the all-peak average tends to exhibit some of the variability inherent in the quartz peak standard with the end result that the normalized peaks from the other component minerals tend to exhibit more variability than they should. 
Table 5.3: Diffraction energy distribution in a typical muscovite-bearing schist record.

\begin{tabular}{ccccc} 
Mineral $\Rightarrow$ & Quartz & Chlorite & Muscovite & Feldspar \\
\hline Peaks $(\%) \Rightarrow$ & 44 & 16 & 25 & 16 \\
Intensity $(\%) \Rightarrow$ & 49 & 17 & 21 & 14 \\
\hline
\end{tabular}

A second approach was then tried which was based on the average intensity of only 12 major reflection peaks. Although the number of peaks was reduced, an effort was made to ensure that the selected peaks were drawn as evenly as possible from each of the component minerals. In the case of the muscovite-bearing schist, the selected peaks are listed in Table 5.4 below:

Table 5.4: Selected muscovite-bearing schist peaks for 12-peak normalization.

\begin{tabular}{|c|c|c|c|c|}
\hline$\alpha$ Spacing $(\AA)$ & Chlorite & Muscovite & Quartz & Feldspar \\
\hline 14 & $x$ & & & \\
\hline 10 & & $x$ & & \\
\hline 7 & $x$ & & & \\
\hline 5 & & $x$ & & \\
\hline 4.7 & $x$ & & & \\
\hline 4.26 & & & $x$ & \\
\hline 3.52 & $x$ & & & \\
\hline 3.34 & & $x$ & $x$ & \\
\hline 3.19 & & & & $x$ \\
\hline 2.45 & $x$ & & & \\
\hline 1.82 & & & $x$ & \\
\hline 1.54 & $x$ & & $x$ & \\
\hline
\end{tabular}

The mineral, feldspar, is deliberately under-represented, for two reasons. The first is that, as can be seen in Table 5.2, feldspar has a much higher compositional variability. The second reason is that feldspar is a major mineral component of the volcanic ash that is found in most fine-fraction samples, and, consequently, its variability is even higher in the fine-fraction than it is in the bedrock.

The "12-peak average" normalization procedure was applied to the same 14 bedrock samples as had been used to evaluate the quartz and the all-peak normalization procedures. As can be seen from the data in Table 5.2, a lower variability was produced by this method than by the previous two attempts. It was decided, therefore, to use the "12-peak average" as the sole normalization 
standard for the relative mineral abundance work. For reasons which will be explained later, it was not necessary to develop separate 12-peak normalization standards for work relating to the other parent materials that were found in the study area.

\subsection{Results}

\subsubsection{Mineral Identification}

From the description in Muller (1967) of mineral assemblages to be found within the confines of the study area, it was determined that it would be necessary to differentiate the various mineral series using the $\mathbf{X}$-ray diffraction records. The standards which were employed in this study to differentiate among chlorite, vermiculite and kaolinite were detailed in Chapter 4. However, in view of the differences in weathering stability among individual mica species, as indicated by the weathering sequences outlined earlier, it is necessary to correctly identify the mica species in all parent material and fine-fraction samples in order to understand the mineral depletion patterns within the study area.

In most instances, a mica sub-group can be identified through the relative intensity of the (001) and (002) reflections. The $5 \AA$ peak is stronger relative to the $10 \AA$ peak in the dioctahedral sub-group than it is in the trioctahedral subgroup (Nagelschmit, 1937 and Brown and Brindley, 1980). On this basis, all the mica in Lithological Zone 1, exclusive of Sites 1L1-10, was tentatively identified as dioctahedral (i.e., muscovite), and the mica at Sites $1 \mathrm{~L} 1-10$ as trioctahedral (i.e., biotite).

A more precise determination of mica species was carried out by peak intensity comparison on several samples of di- and trioctahedral samples, the results of which are presented in Tables 5.5 and 5.6. Much of the data given for $d$-spacings in the reference works are based on experimental results using randomly oriented powder samples whereas the samples prepared for this study 
are in the preferred orientation mode. Oriented samples produce relatively weaker low angle (high $d$-spacing) reflections than randomly oriented samples (Reynolds, 1976).

Reynolds (1976) has calculated conversion factors for adjusting the intensity values of the $(001)$ reflections from mica and smectite. However, these data are only applicable to samples processed in diffractometers equipped with Soller slit detector units. The Carleton University diffractometer is not so equipped; instead, it uses a scintillation detector with a curved monochrometer. A literature search for sample orientation corrective factors for use with this equipment was unsuccessful. However, Reynolds (1976) states: "Oriented clay specimens produce diffraction profiles that are controlled by a Lorentz factor very close to the random powder form. For all but the most critical work, the investigator will make only small errors if he applies the random powder form," but he also cautioned that the divergences from the powder form are greatest at lower values of $2 \theta$, and, consequently, the (001) reflection should be avoided when analyzing clay minerals if great accuracy is required.

Mica species determination in the study area samples is further complicated by the fact that the $(003)$ peak is coincident with the quartz peak at $3.34 \AA$. Normally, most of the quartz can be removed by eliminating the sand and silt-sized fractions, as very little quartz will weather to clay-size. However, it would be very difficult to collect sufficient clay fraction materials from the small bedrock hand samples, and, in any case, the end result would probably be to remove much of the coarser-grained mica as well.

Fortunately, the (003) reflection is not diagnostic in distinguishing between species for either dioctahedral or trioctahedral micas. In Table 5.5, a composite of 14 oriented bedrock samples collected from sites throughout the study area is compared to powder sample reference profiles of the end-members of the dioctahedral sub-group provided in Brown and Brindley (1980, Table 5.7). Despite the interpretation limits inherent in comparing oriented to powder samples and the absence of the (003) reflection, the relatively high (002) and 
(005) peaks and the presence of a (004) peak in the composite profile would appear to confirm that the mica in these samples is indeed of the muscovite species.

Table 5.5: Relative intensity of (00) peaks of dioctahedral micas.

\begin{tabular}{|c|c|c|c|c|c|}
\hline Peak Order $\Rightarrow$ & $(001)$ & (002) & (003) & (004) & (005) \\
\hline Reference Muscovite $\Rightarrow$ & $\leq 100$ & 55 & $\leq 100$ & 20 & 75 \\
\hline Average of 14 Rock & 100 & 62 & $?$ & 15 & 67 \\
\hline \multicolumn{6}{|l|}{ Samples $\Rightarrow$} \\
\hline Reference Paragonite $\Rightarrow$ & 30 & 20 & 100 & - & 30 \\
\hline
\end{tabular}

A separate determination of mica species was made for nine bedrock samples collected from the northernmost sites on transect $1 \mathrm{~L}$. Based on the very low peak intensities of the 002 reflections, a preliminary determination was made that these were trioctahedral micas. Subsequent comparison to the two powder reference sample profiles of the end-members of this sub-group from Brown and Brindley (1980), shown in Table 5.6, indicates that these micas are of the biotite species. This determination is based on the low intensity of the 004 and 005 reflections.

Table 5.6: Relative intensities of the $(00 /)$ peaks of trioctahedral micas.

$\begin{array}{cccccc}\text { Peak Order } \Rightarrow & (001) & (002) & (003) & (004) & (005) \\ \text { Reference Biotite } \Rightarrow & 100 & 20 & 99 & 10 & 10 \\ \text { Average of 9 Rock Samples } \Rightarrow & 100 & 6 & ? & 15 & 14 \\ \text { Reference Phlogopite } \Rightarrow & \leq 100 & 21 & \leq 100 & 30 & 65\end{array}$

Previous work in the region (Howes, 1991) indicated that aeolian additions would be found in the study area fine-fraction. In order to identify these additions, it was felt that it would be useful to identify individual feldspar species. Brown and Brindley (1980) indicate that peaks at 4.23-4.21, at 3.99, and again at $3.31-3.29 \AA$ are characteristic of the orthoclase species, and that peaks at $4.04-4.02,3.67-3.62,3.21-3.15$, and $3.04-2.91 \AA$ are characteristic of the plagioclase species. Considering that some of these peaks are also produced by other minerals expected to be present in the study area parent materials, only a 
peak at $4.23-4.21 \AA$ would be unequivocally diagnostic for orthoclase and a peak at $4.04-4.02 \AA$ would be unequivocally diagnostic for plagioclase feldspar. Therefore, the identification of feldspar species was based on the presence or absence of these two peaks.

\subsubsection{Parent Materials and Subsequent Additions}

\subsubsection{Zone 1 Parent Material}

Within Lithological Zone 1, the predominant parent material was found to be mica-schist bedrock, as described in Muller (1967). X-ray diffraction confirmed that this rock consisted of iron-rich chlorite, muscovite, quartz and plagioclase feldspar. The X-ray diffraction record from a typical site (1B6) is shown in Figure 5.2, along with the record of the fine-fraction sample from the same site. The striking similarity in terms of relative peak heights with each pattern and the diffraction peaks present on the two records is indicative of the predominant influence of the bedrock parent material in the mineral abundance of the local fine-fraction material. This variety of mica-schist was found throughout Zone 1, with the exception of the first 9 sites of transect $1 \mathrm{~L}$.

Along the first 9 sites of transect $1 \mathrm{~L}$, the local bedrock mica-schist was found to contain biotite, rather than the muscovite found at all other sites. This result was anticipated as a result of the earlier work of Muller (1967). The X-ray diffraction record from site 1 L9 is typical (Figure 5.3). The influence of the local bedrock parent material on the local fine-fraction at this site is obscured somewhat by the partial transformation in the fine-fraction from biotite to vermiculite and by random interstratification of the clay minerals, the recognition of which was discussed in Chapter 4. 


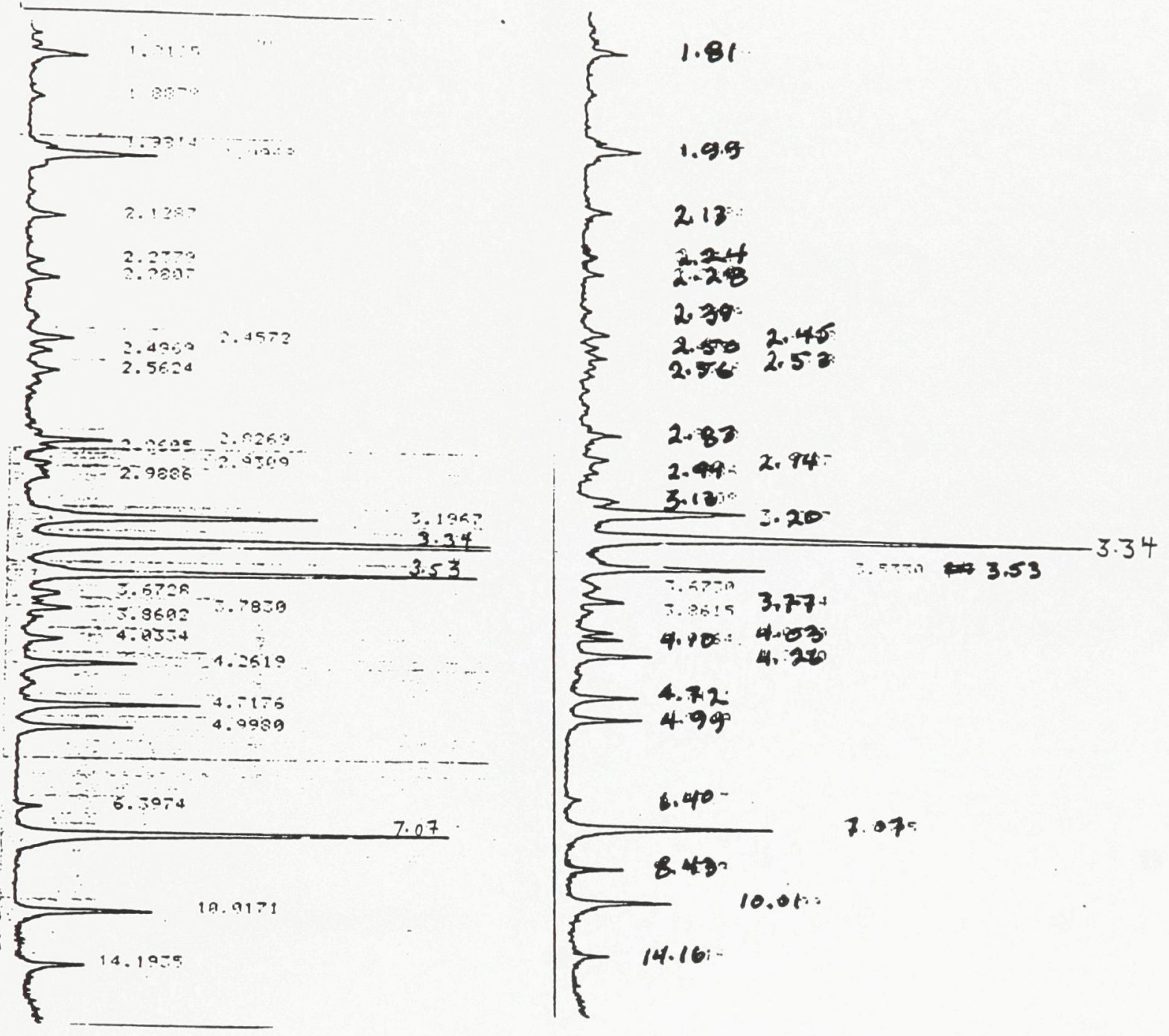

Figure 5.2: X-ray diffraction records from Site $1 B 6$.

Left: a sample of mica-schist taken from a local bedrock outcropping.

Right: a sample of the local fine-fraction. Note the close similarity in terms of relative peak intensities (internal to the sample) and distribution of the diffraction peaks. 


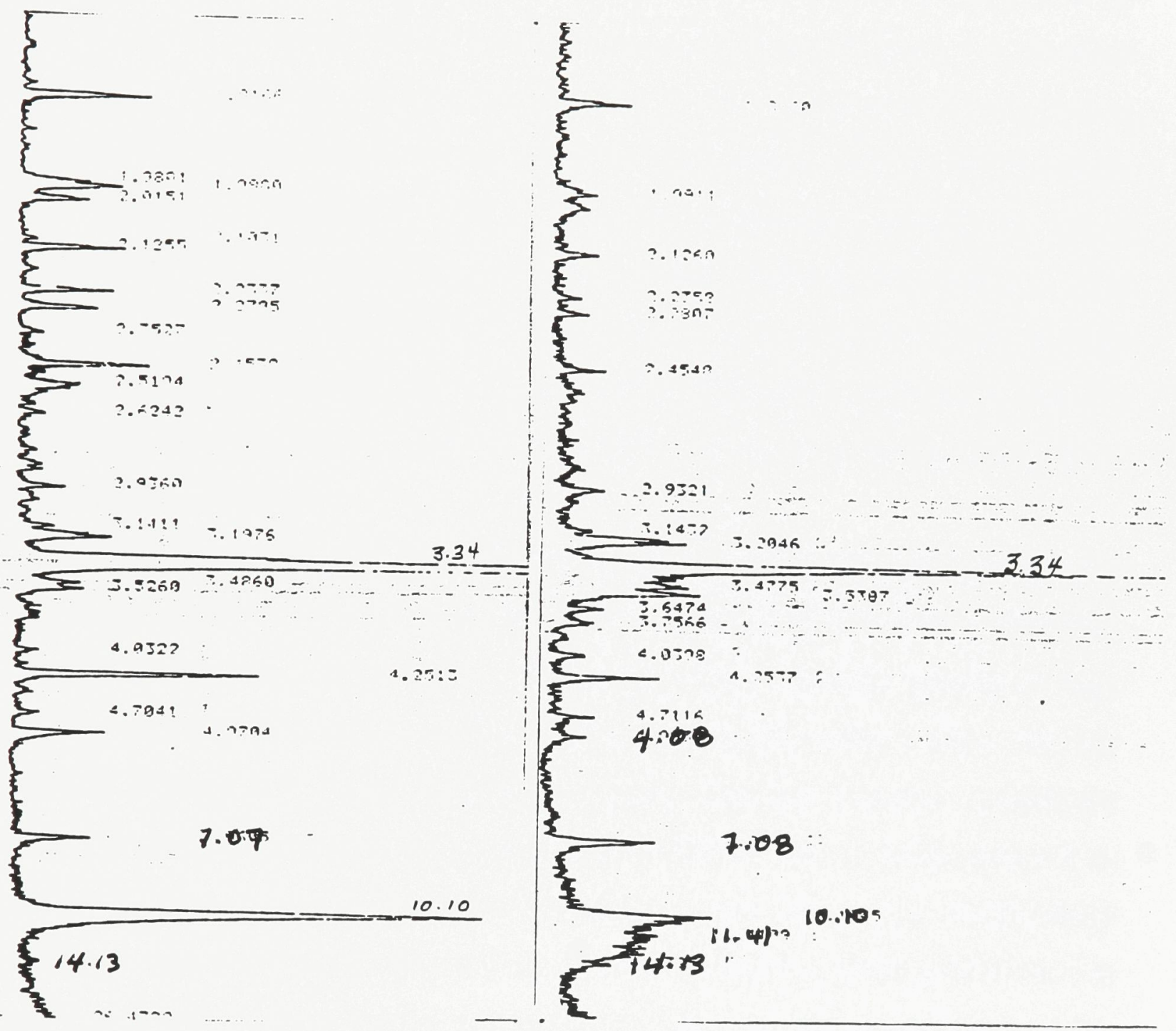

Figure 5.3: X-ray diffraction records from Site 1 L9.

Left: a sample of mica-schist taken from a local bedrock outcropping. Right: a sample of the local fine-fraction. The influence of the bedrock on the fine-fraction as reflected in the size and distribution of diffraction peaks is obscured somewhat by the transformation of biotite to vermiculite and by random interstratification in the fine-fraction material. 


\subsubsection{Volcanic Ash Additions}

In addition to the fine-fraction material developed from the local bedrock, it was anticipated that the study area regolith would contain aeolian deposits of volcanic ash and loess. The presence of volcanic ash in the region was first described in detail by Capps (1915), and later by Bostock (1952). This ash was subsequently radiocarbon-dated at 1147 years B.P. or AD 803 by Clague et al. (1995). In the St. Elias Mountains this ash forms a discrete stratum, 1-3 cm thick embedded in Neoglacial (modern) loess, and in this association it is found at sites along the shoreline of Kluane Lake on the western border of the study area. Elsewhere in the study area, it is found in discrete pockets or, more commonly, as a fully integrated component of the regolithic fine-fraction. It is also found on upland surfaces as a thin layer on the surface of the regolith among the tors, and although it is slowly being integrated downwards into the other fine-fraction materials, there is no evidence that it is being covered by further aeolian deposition.

When viewed through an optical microscope, the ash is seen to consist mostly of glass beads with small amounts of crystalline material and void spaces embedded in the individual beads. The beads have a specific gravity of less than unity, and hence would be highly mobile when suspended in water. As can be seen in Figure 5.1, X-ray diffraction reveals that the mineral component consists principally of amphibole, plagioclase feldspar, and a small amount of magnetite. The presence of plagioclase feldspar in the ash would compromise any study of relative feldspar abundance in the fine-fraction developed from the mica-schist parent material as the feldspar component of both materials is of the plagioclase species.

The amphibole component, on the other hand, is not found in the micaschist parent material. However, the presence of amphibolite was reported as a component of the Yukon Complex in Lithological Zone 1 by Muller (1967, Map $1177 \mathrm{~A})$, and so a survey of the 123 sites of this zone was conducted to determine the extent of the presence of amphibolite. Only one site, 1L10 
(located at the boundary between the biotite-bearing and the muscovite-bearing schists), was found to contain amphibolite. The mineral assemblage of a rock sample, taken from a local bedrock outcropping, was found through $\mathrm{X}$-ray diffraction analysis (Figure 5.4) to consist mainly of amphiboles with peaks at $8.40,3.12$, and $2.71 \AA$ and with some plagioclase feldspar with peaks at 6.37 , $4.03,3.65,3.27$ and $3.19 \AA$. Neither chlorite nor quartz was detected, and the only indication of mica is a very small peak at $5 \AA$. The possible presence of pyroxene was suggested by small peaks at 3.27 (split peak), 2.94, and 2.60.

An analysis of the fine-fraction materials at site $1 L 10$ proved equally instructive. Despite the predominance of amphiboles in the bedrock sample, the amphibole peaks in the fine-fraction X-ray diffraction records were very low in comparison to the chlorite and quartz peaks which, as noted above, are completely missing in the bedrock sample. The relatively small fine-fraction amphibole peak at $8.4 \AA$, is no greater than that found at other sites in Zone 1 where the sole known source of amphibole is the deposition of volcanic ash. This suggests that the amphibolite outcrop is of such limited extent as to be incapable of exerting a detectable influence on the adjacent fine-fraction materials, and, therefore, the presence of the $8.4 \AA$ peak in a Zone 1 fine-fraction sample can justifiably be treated as a volcanic ash marker even if other undetected amphibole bedrock outcrops should exist.

Assuming that the $8.4 \AA$ peak in fine-fraction samples is a reliable volcanic ash marker, volcanic ash is widespread in Zone 1 fines since a detectable $8.4 \AA$ peak was found on over $90 \%$ of the fine-fraction records. However, widespread or not, the presence of volcanic ash throughout the fine-fraction would compromise the validity of a feldspar depletion study only if the amount of feldspar within the ash were large enough to distort the results. To test the effect of the presence of volcanic ash on the amount of feldspar in the regolithic finefraction, a partial correlation was conducted using the diffraction records of 15 fine-fraction samples from the muscovite-bearing schist sites. In order to ensure that all five ground surface zones were equally represented, 3 samples were 

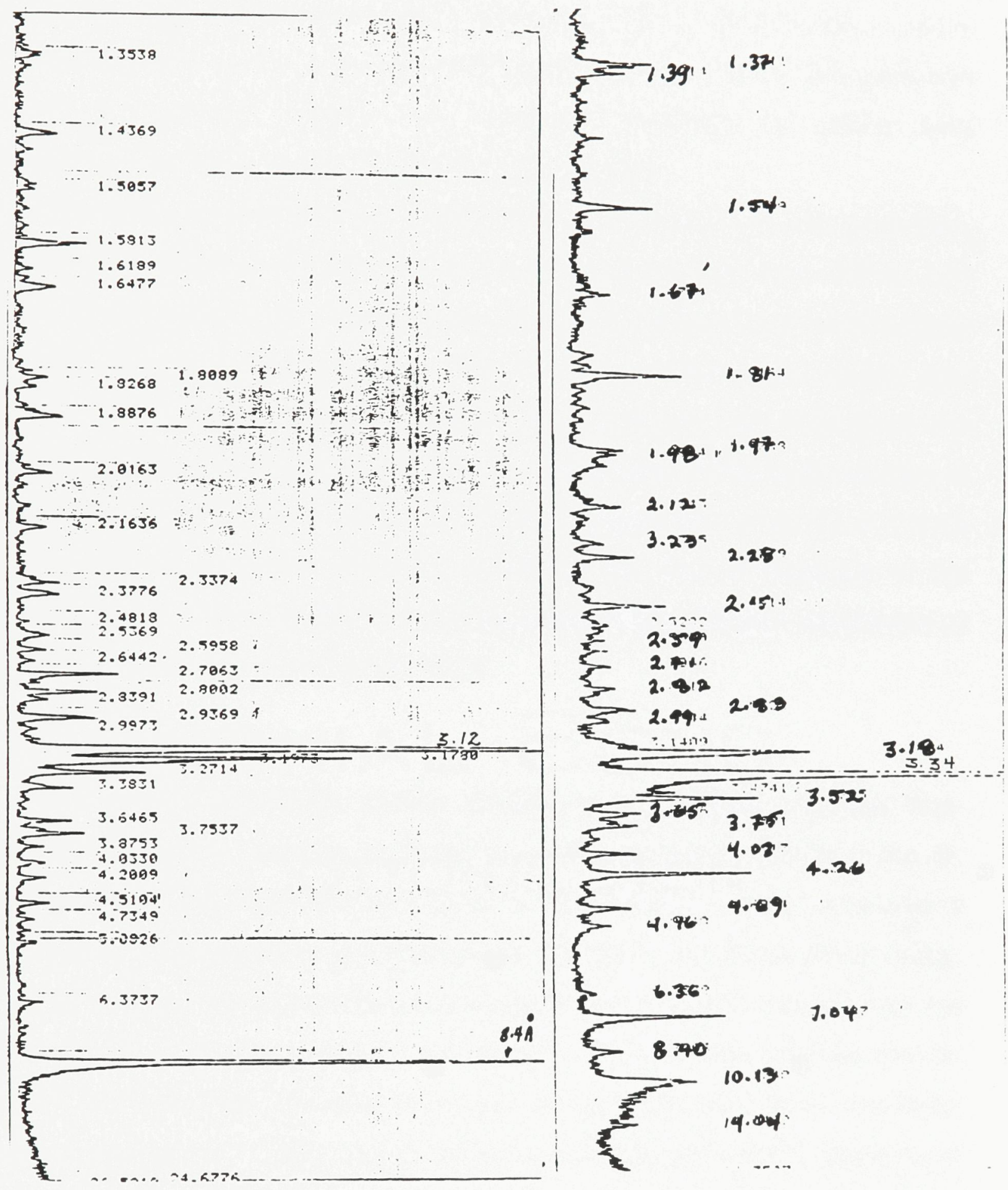

Figure 5.4: X-ray diffraction records from Site $1 \mathrm{~L} 10$.

Left: a sample of the local amphibolite outcrop. Note the predominant peak at $8.4 \AA$. Right: a sample of the local fine-fraction. The $8.4 \AA$ peak in this case is no greater than at other nearby sites where the only source of amphibole is volcanic ash. 
randomly selected from each zone. The diagnostic $4.26 \AA$ quartz peak was chosen to act as the surrogate for the original fine-fraction since quartz is a component of the original parent material (but not of volcanic ash) and weathers very slowly under most environmental conditions. The $8.4 \AA$ amphibole marker peak was selected as the surrogate for the volcanic ash. The $3.19 \AA$ peak was selected to represent feldspar (the dependent variable). All peaks were normalized using the 12-peak average for each sample.

The partial correlation test revealed that when amphibole was controlled, the correlation coefficient of quartz and feldspar was reduced from .095 to 036 $(>62 \%)$. On the other hand, the correlation coefficient of amphibole and feldspar was only marginally reduced from .238 to .215 (<10\%) when quartz was controlled. This suggests that the deposition of volcanic ash throughout the study area may have significantly increased the amount of feldspar resident in the fine-fraction, and, hence, the present feldspar component of the Zone 1 fines does not provide a reliable basis for estimating the rate of depletion of the original feldspar. Confirmation of the significance of the feldspar component of volcanic ash is discussed in Section 5.2.4.

\subsubsection{Loess Additions}

The second detectable aeolian addition to the original regolithic finefraction is loess which is being produced as a result of glacial activity in the St. Elias Mountains. The most common source of loess deposits in the study area is from sediments deposited by the Kaskawulsh Glacier in the Slim's River valley, the mouth of which lies across Kluane Lake approximately $20 \mathrm{~km}$ upwind from the study area. On windy days, airborne movement of loess across the lake can be seen with the naked eye. The loess deposits of the region have been described by Denton and Stuiver (1966) and by Borns and Goldthwait (1966). Deposits of this material found along the southern and eastern shorelines of Kluane Lake are described in Howes (1991). 
An X-ray diffraction record of Neoglacial (Holocene) loess taken from the Slim's River valley is shown in Figure 5.5. It will be noted that this sample contains all of the component minerals identified in the original Zone 1 finefraction (chlorite, mica, quartz and plagioclase feldspar). Therefore, the addition of this loess to the original Zone 1 fine-fraction could distort any calculations of mineral depletion in the latter. It was consequently necessary to determine which Zone 1 sites had been subject to aeolian importation of detectable quantities of loess.

The possibility that the prominent $3.03 \AA$ calcite peak could be used as a reliable marker to indicate the addition of loess to Zone 1 fine-fraction materials was investigated. Muller (1967, Map 1177A) indicated that a minor source of calcite exists in Zone 1 bedrock in the form of recrystallized limestone. As was the case with amphibolite, a deliberate effort was made to seek out samples of re-crystallized limestone in Zone 1 bedrock formations. Only one sample of recrystallized limestone was found in the 123 Zone 1 sites visited. The isolated nature of the re-crystallized limestone find, combined with the lack of an identifiable $3.03 \AA$ calcite peak in the fine-fraction $\mathrm{X}$-ray diffraction records from the same site (Figure 5.6), suggests that the fine-fraction calcite found in other samples in Zone 1 is unlikely to be of local provenance, and, therefore, the presence of calcite in other fine-fraction samples in Zone 1 is most likely the result of aeolian deposition of loess carried into the area by the prevailing westerlies. From this it was concluded that the $3.03 \AA$ peak is a valid marker indicating the addition of loess to Zone 1 fines.

A summary of the Zone 1 calcite occurrences in fine-fraction samples is shown in Table 5.7. 


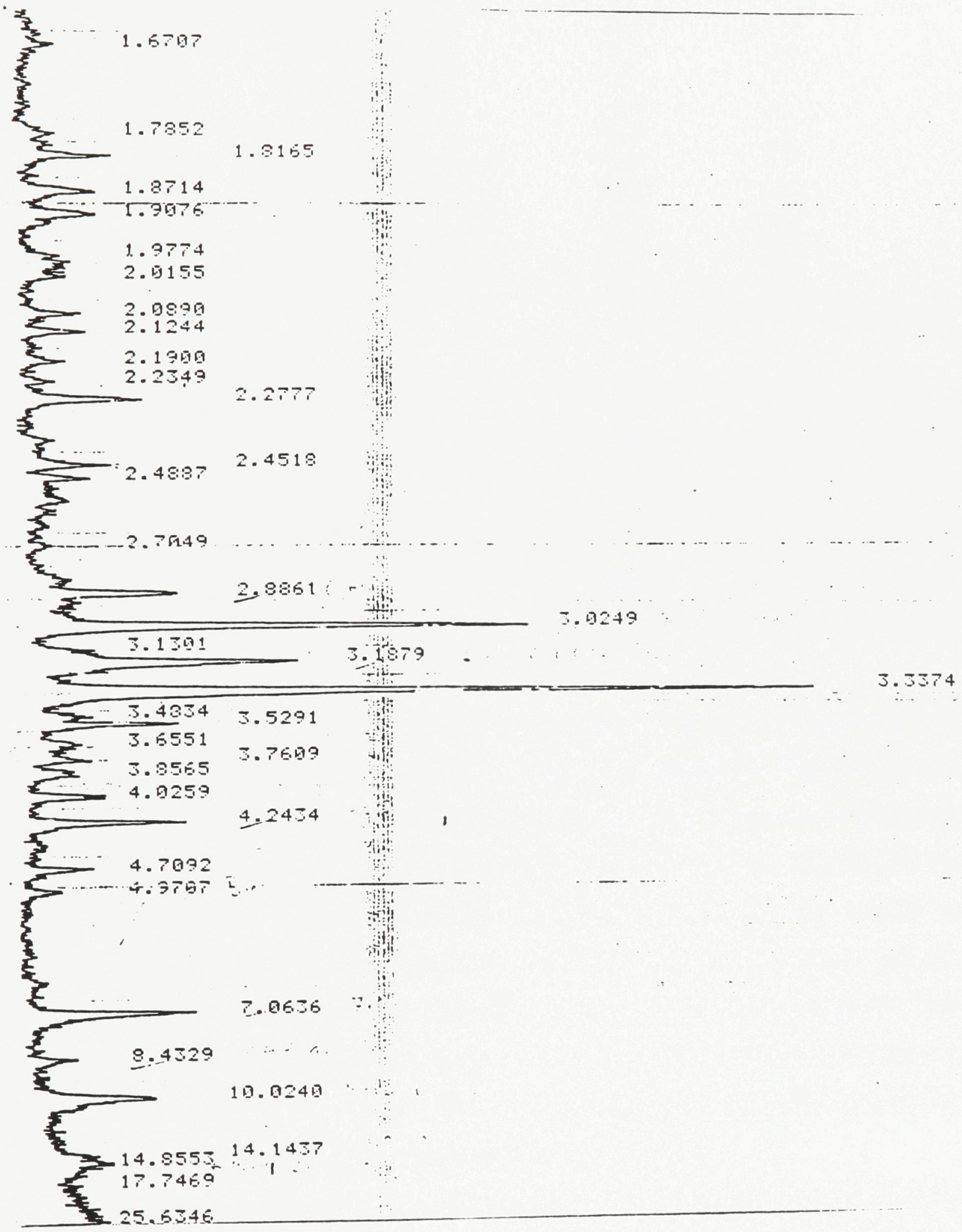

Figure 5.5: X-ray diffraction record of a sample of Neoglacial (Holocene) loess. Note the prominent calcite peak at $3.02 \AA$. 
Table 5.7: Summary of calcite occurrences in Zone 1 fines.

\begin{tabular}{|c|c|c|c|}
\hline Site & $\begin{array}{c}\text { Distance from Kluane Lake } \\
\text { Shoreline }(\mathrm{km})\end{array}$ & Elevation $(\mathrm{m})$ & $3.03 \AA$ * \\
\hline CuC1 & 16 (Jarvis Valley) & 930 & 0.84 \\
\hline $\mathrm{CuC2}$ & 16 (Jarvis Valley) & 900 & 0.69 \\
\hline $1 \mathrm{C} 1$ & 20 (Jarvis Valley) & 745 & nil \\
\hline $1 \mathrm{H} 1$ & 17 (Jarvis Valley) & 945 & nil \\
\hline $1 \mathrm{H} 2$ & 17 (Jarvis Valley) & 1036 & 1.26 \\
\hline $1 \mathrm{M} 1$ & 0.3 (Cultus Creek Valley) & 823 & 1.48 \\
\hline $1 \mathrm{M} 2$ & 1.0 (Cultus Creek Valley) & 838 & nil \\
\hline $1 \mathrm{M} 3$ & 0.2 (Cultus Creek Valley) & 805 & 1.00 \\
\hline $1 \mathrm{M} 4$ & 2.8 (Cultus Creek Valley) & 860 & 1.07 \\
\hline $1 \mathrm{~A} 14$ & 2.8 (Cultus Creek Valley) & 869 & nil \\
\hline 1B1 & 1.0 (Cultus Creek Valley) & 853 & nil \\
\hline
\end{tabular}

Of the six sites located in the Cultus Creek valley below $970 \mathrm{~m}$ elevation, calcite was detected in 3 of the 6 fine-fraction samples. The proximity of these sites to the Kluane Lake shoreline, and the fact that they lie downwind from a known source of loess from the Slim's River valley, suggest that the original finefraction materials at these sites have been adulterated by the loess deposition. In the Jarvis River valley, even further downwind, calcite was detected in 2 of 5 sites below 1040 m elevation.

No calcite was detected anywhere in Zone 1 above an elevation of $1036 \mathrm{~m}$. It is of interest to note that on Pre-Nisling surfaces at sites which are vegetation-free, volcanic ash deposits are found right on the surface and are not covered by any subsequent aeolian deposition. This, plus the observation by Denton and Stuiver (1967) that loess (including Pre-Neoglacial loess) is generally absent from valley walls above $4500 \mathrm{ft}(1370 \mathrm{~m})$ elevation in the $\mathrm{St}$ Elias Mountains many kilometers upwind from the study area, suggests that there is little risk that loess adulteration has altered the original fine-fraction mineral abundance to the extent that mineral depletion analysis would be invalidated for any study area sites above $1040 \mathrm{~m}$ elevation.

However, as outlined above, several of the Post-glacial Ground Surface Zone sites in the Cultus and upper Jarvis valleys indicate, by the presence of calcite, that their original fine-fraction mineral abundance may have been altered by aeolian importation. The potential effect of the addition of loess to the 


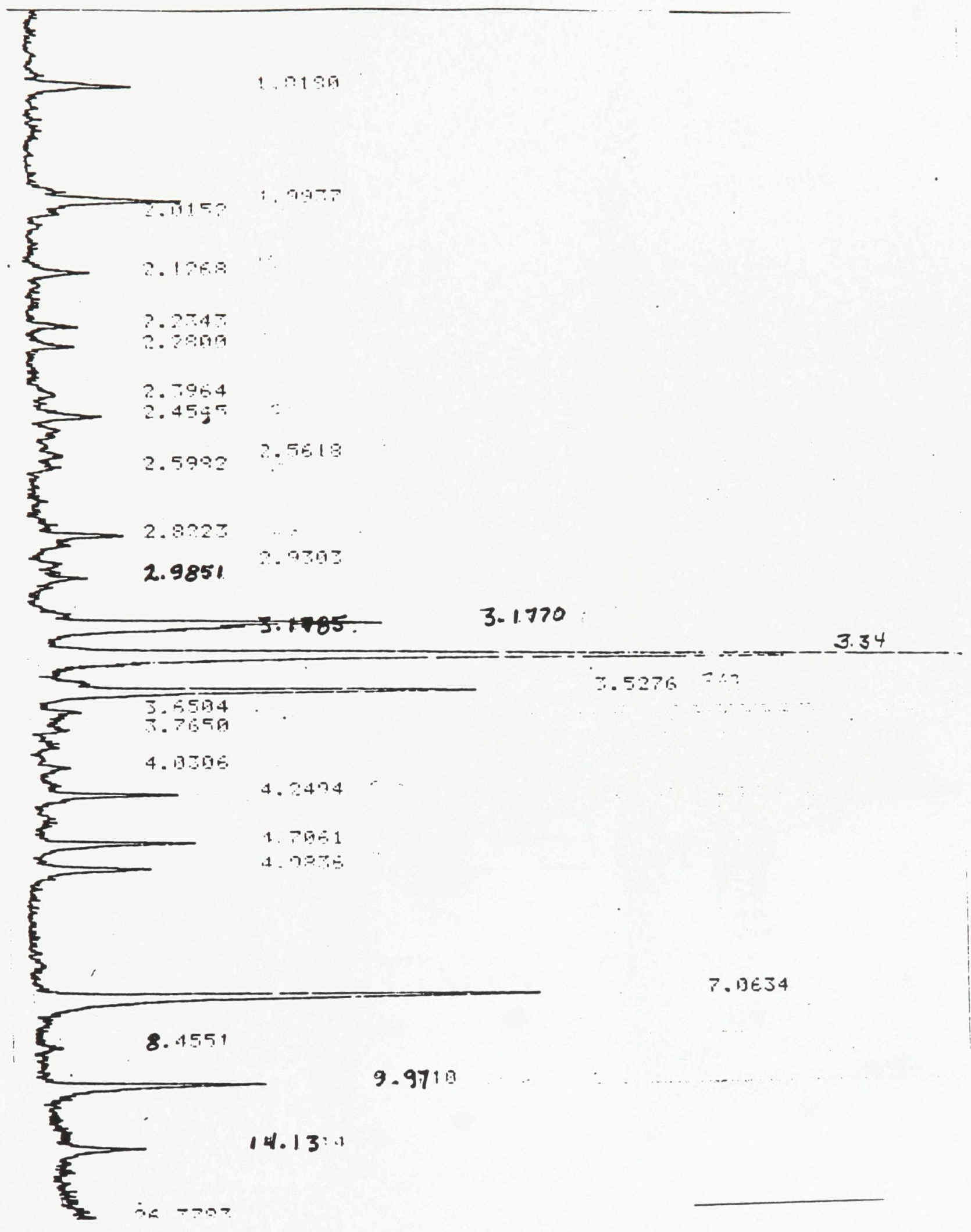

Figure 5.6: $X$-ray diffraction record of a fine-fraction sample from site $1 \mathrm{~K} 9$. Although a single clast of re-crystallized limestone was found at this site, evidence that it influenced the composition of this fine-fraction sample. Note that the characteristic $3.02-3.04 \AA$ calcite peak is absent. 


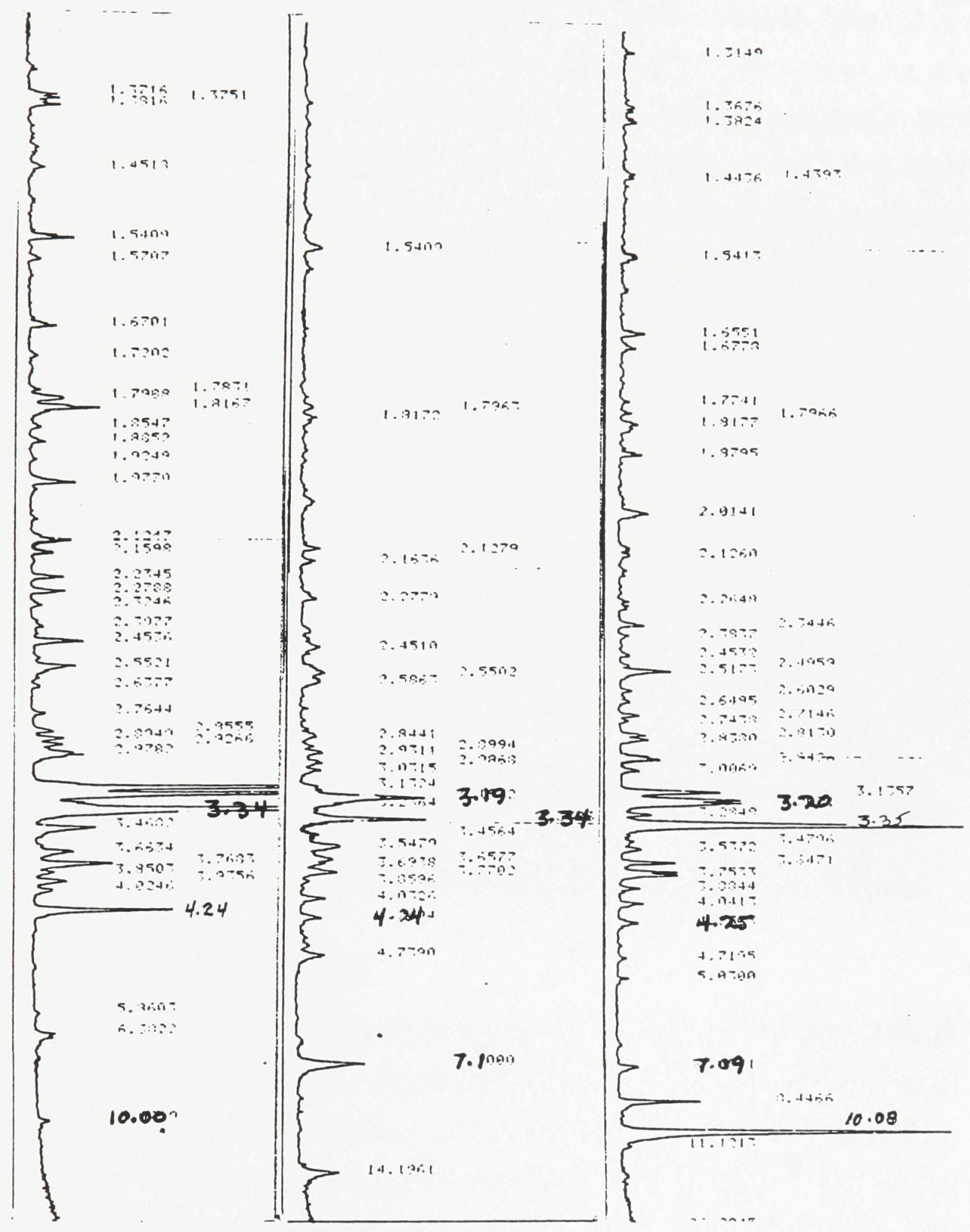

Figure 5.7: X-ray diffraction records of 3 rock samples from site $2 \mathrm{~A} 1$. Note the striking differences in mineral composition. A high degree of variability in mineral composition proved to be a characteristic of the Ruby Range batholith. 
original fine-fraction materials at the affected Post-glacial Ground Surface Zone sites can be estimated by comparing the $3.03 \AA$ peak intensity ratio of an unadulterated Neoglacial loess sample from the Slim's River Valley to the comparable peak intensity ratios of samples from the loess-contaminated sites within the study area. The recorded $3.03 \AA$ peak intensity ratio of the Slim's River valley Neoglacial loess sample (Figure 5.5) is 2.94 whereas the comparable peak intensity ratios from the loess-contaminated sites range from 1.48 to 0.69 . The fact that the $3.03 \AA$ peaks recorded from the loess-contaminated study area sites are still relatively strong suggests that the loess addition to the original fine-fraction material is appreciable. A comparison of the fine-fraction mean peak intensity ratios of the four loess-free Post-glacial Ground Surface Zone sites to the unadulterated Neoglacial loess sample from the Slim's River valley (Table 5.8) suggests that, although the effect would be minimal on the $7 \AA$ peaks, the addition of loess would tend to depress the 5,4.26, and $3.19 \AA$ peaks, while simultaneously tending to enhance the $8.4 \AA$ peak.

Table 5.8: Comparison of four loess-free Post-glacial samples to unadulterated loess.

\begin{tabular}{cccccc} 
& \multicolumn{3}{c}{ The record from the unadulterated loess sample is shown in Figure 5.5.} \\
& $7 \AA$ & $5 \AA$ & $4.26 \AA$ & $3.19 \AA$ & $8.4 \AA$ \\
\hline Post-glacial & .99 & .23 & .99 & 1.45 & .21 \\
Loess & 1.00 & 18 & .71 & 1.29 & 49
\end{tabular}

\subsubsection{Zone 2 Parent Material}

Rock sampling in Zone 2 revealed that the necessary degree of mineral homogeneity to provide an adequate parent material baseline, for the purpose of determining relative mineral abundance in the associated fine-fraction materials, does not exist. This was readily apparent from the initial fieldwork in Zone 2 at a feature described by Muller (1967) as a St. Elias cirque basin (Site 2A1). This basin is lined with sheeting debris from the cirque walls and as such provides a unique cross-sectional view of the variability of mineral composition within the Ruby Range batholith. In all, six separate rock samples were collected at this 
site; all of which displayed strikingly different compositions from each other. The X-ray diffraction records of 3 of these samples are shown in Figure 5.7 and graphically illustrate the degree of variability. The problem was manifest throughout the Zone 2 portion of the study area. Differences in the mineral composition of rock outcrops were readily apparent to the naked eye from transect to transect, and, in some instances, even within individual transects; e.g., three changes in mineral composition on transect $2 \mathrm{D}$ and two on transect 2B. Since a high degree of bedrock homogeneity would be necessary to provide a valid baseline for any mineral depletion analysis of Zone 2 fines, it was decided it would not be worthwhile to include the Zone 2 samples in the relative mineral abundance portion of this study.

\subsubsection{Chronosequence Analysis}

As outlined earlier, a number of mineral depletion studies (Wang and Ross, 1989; Wang et al., 1986; Ross et al., 1984; Shroba and Birkeland, 1983; Bockheim, 1979; and Foscolos et al., 1976) have been conducted in areas in which the range of temperature and precipitation conditions encompass those which prevail within the study area. What emerged from these studies is that chlorite depletion should be complete in all fine-fraction materials, except those of Holocene origin. The exception to this is that chlorite has been shown to survive in calcareous pre-Holocene fines as old as approximately 150,000 years (Shroba and Birkeland, 1983). However, as reflected in Table 5.7, only six Zone 1 fine-fraction samples were found to contain calcite.

As the presence of chlorite is readily detected in all Zone 1 fine-fraction samples in the soil-size range, one might conclude that none of these fines predates the Holocene. However, the study area fines are different in one important aspect from all other cases studied -- the fine-fraction materials in the study area are confined to a thin surface veneer 30 to $50 \mathrm{~cm}$ thick, and bedrock outcroppings protrude throughout. Bedrock sources so close to the surface, 
especially the easily weathered mica-schist bedrock, no doubt continually add fresh parent material to the existing fine-fraction. This process is readily detectable in Zone 1 fine-fraction samples. During sieving, it was found that virtually all "fine-fraction" samples were found to contain schist chips in the 2 to $5 \mathrm{~mm}$ range which had escaped detection during collection. It is estimated that these chips constituted around 2 to $10 \%$ by volume of the total sample. Such adulteration of older fine-fraction materials by freshly weathered bedrock could probably add sufficient fresh chlorite to obscure any depletion which may have occurred within the fine-fraction, thereby rendering it impossible to differentiate between fines of pre-Holocene and Holocene origin on the basis of the presence or absence of chlorite.

Nevertheless, it was anticipated that a relative chronosequence could be identified from the $X$-ray diffraction records by calculating changes in the mean peak intensity ratio of the common minerals in successively older ground surface zones. These changes would approximate degrees of mineral depletion for each ground surface zone relative to the others. A summary of zonal mean peak intensity ratio calculations for all muscovite-bearing schist sites is shown in Table 5.9.

For the 7 and $5 \AA$ peaks there is little difference between mean intensity ratios for the Pre-Nisling, Nisling, and Ruby surfaces, but these ratios drop noticeably for the St. Elias and Post-glacial ground surface zones. As would be expected from the 5 and $7 \AA$ results, the $4.26 \AA$ (quartz) ratios show a reverse trend with uniformly low ratios for the Pre-Nisling, Nisling, and Ruby surfaces and noticeably higher ratios for the St. Elias and Post-glacial zone surfaces. These results are not what one would anticipate from the chronosequence model. According to the model, the peak intensity ratios for chlorite/vermiculite and muscovite should have been lowest on the oldest (Pre-Nisling) surfaces, and higher on each succeeding surface. 
Table 5.9: Comparison of fine-fraction to bedrock samples in the muscovite-schist zone.

\begin{tabular}{|c|c|c|c|c|c|}
\hline $\begin{array}{l}\text { Mean Peak } \\
\text { Intensity } \\
\text { Ratios } \Rightarrow\end{array}$ & $\begin{array}{c}\text { Chlorite / } \\
\text { Vermiculite } \\
7 \AA\end{array}$ & $\begin{array}{c}\text { Muscovite } \\
5 \AA\end{array}$ & $\begin{array}{l}\text { Quartz } \\
4.26 \AA\end{array}$ & $\begin{array}{c}\text { Amphibole } \\
8.43 \AA\end{array}$ & $\begin{array}{c}\text { Plagioclase } \\
\text { Feldspar } \\
3.19 \AA\end{array}$ \\
\hline $\begin{array}{c}\text { Ground } \\
\text { Surface } \downarrow\end{array}$ & & & & & \\
\hline Pre-Nisling $\Rightarrow$ & 1.60 & .41 & .76 & .08 & .95 \\
\hline Nisling $\Rightarrow$ & 1.56 & .42 & .71 & .21 & 1.36 \\
\hline Ruby $\Rightarrow$ & 1.61 & .42 & .68 & .25 & 1.59 \\
\hline St.Elias $\Rightarrow$ & 1.15 & .23 & .89 & .22 & 1.42 \\
\hline $\begin{array}{c}\text { Post-glacial } \\
\text { Ground } \\
\text { Surface Zone } \\
\Rightarrow\end{array}$ & .99 & .23 & .99 & .21 & 1.45 \\
\hline $\begin{array}{c}\text { Muscovite- } \\
\text { bearing } \\
\text { Schist } \Rightarrow\end{array}$ & 2.13 & .49 & .55 & nil & .95 \\
\hline
\end{tabular}

* mean of 30 bedrock samples

Similarly the 8.43 (amphibole) and $3.19 \AA$ (feldspar) peak intensity ratios do not conform to the chronosequence model. However, this is to be expected because it has been established that all of the amphibole and much of the feldspar were deposited in modern times as components of the volcanic ash. These minerals display a fairly even distribution throughout the study area except on the highest (Pre-Nisling) surfaces. Their relative scarcity on the highest surfaces possibly arose from the ease with which the unconsolidated ash deposits could be rapidly transported down-slope with rain and snow-melt runoff in the first few months following initial deposition. On lower slopes, transportation would be encumbered by vegetation, and eventually individual ash particles at these elevations would become entrained in the original finefraction material. An alternative explanation for the relative scarcity at higher elevations may be related to limitations on the transportation capability of the wind during the original deposition. 
Statistical testing of the observed trends was conducted using the Student's $t$-test on mean peak intensity ratios. The results are summarized in Table 5.10:

Table 5.10: Student's $t$ test summary ground surface zonal differences.

\begin{tabular}{|c|c|c|c|c|c|}
\hline $\begin{array}{c}\text { Peak } \\
\Downarrow\end{array}$ & $\begin{array}{l}\text { Pre-Nisling/ } \\
\text { Nisling } \\
\text { df }=65\end{array}$ & $\begin{array}{l}\text { Nisling/ } \\
\text { Ruby } \\
\text { df=38 }\end{array}$ & $\begin{array}{l}\text { Ruby/ } \\
\text { St.Elias } \\
d f=18\end{array}$ & $\begin{array}{l}\text { St.Elias/ } \\
\text { Post-glacial } \\
\text { df }=25\end{array}$ & $\begin{array}{l}\text { Ruby/ } \\
\text { Post-glacial } \\
\text { df }=35\end{array}$ \\
\hline $7 \AA$ & .37 & .38 & $.04^{*}$ & 22 & $.005^{*}$ \\
\hline $5 \AA$ & .40 & .49 & $.005^{*}$ & 34 & $.005^{*}$ \\
\hline $3.19 \AA$ & $.005^{*}$ & .16 & .18 & .15 & .36 \\
\hline $8.4 \AA$ & $.005^{*}$ & .31 & 34 & .34 & 42 \\
\hline $4.26 \AA$ & .12 & .34 & $.05^{*}$ & .14 & $.005^{*}$ \\
\hline
\end{tabular}

Setting the null hypothesis rejection level at .05 , the 7,5 , and $4.26 \AA$ mean peak intensity ratios show significant differences at the Ruby/St. Elias and Ruby/Postglacial boundaries. The 8.43 and $3.19 \AA$ mean peak intensity ratios show significant differences only at the Pre-Nisling/Nisling boundary.

Based on an assumption that the peak intensity ratios are a close approximation of relative mineral abundance in a given sample, the calculated percentage depletion of individual component minerals of the original parent material is summarized in Table 5.11:

Table 5.11: Indicated fine-fraction mineral depletion in the muscovite-schist unit.

\begin{tabular}{c|cc|c}
$\begin{array}{c}\text { Ground Surface } \\
\text { Zone } \Downarrow\end{array}$ & $\begin{array}{c}\text { Chlorite } \\
\text { Depletion (\%) }\end{array}$ & $\begin{array}{c}\text { Muscovite } \\
\text { Depletion } \\
(\%)\end{array}$ & $\begin{array}{c}\text { Quartz } \\
\text { Relative } \\
\text { Enrichment (\%) }\end{array}$ \\
\hline Pre-Nisling & 25 & 16 & 38 \\
Nisling & 27 & 14 & 29 \\
Ruby & 24 & 14 & 24 \\
St. Elias & 46 & 53 & 62 \\
Post-glacial & 54 & 53 & 88
\end{tabular}

The figures calculated for chlorite probably understate the actual rate of depletion as they are based on zonal mean peak intensity ratios for the $7 \AA$ peak which, as previous work has shown, also includes reflections of secondary 
vermiculite which developed in many of the study area fines from weathered muscovite. However, these understated depletion rates are still noticeably higher in most instances than the corresponding indicated muscovite depletion rates, as one would expect from the various published mineral stability and weathering indices. The relative enrichment of the quartz component of the fines also conforms to a trend which one would predict from the indices. However, the higher depletion of both chlorite and muscovite on the St. Elias and Post-glacial surfaces, in contrast to the older surfaces, does not conform to the chronosequence model. The possibility that this anomaly is due to topographic factors is examined in the next section.

\subsubsection{Toposequence Analysis}

In order to provide the necessary sample sizes for toposequence statistical analysis, the arrangement of sampling data by individual transects was abandoned in favor of data arranged in descending order of site elevation regardless of transect. This was done for the fine-fraction samples for the 102 sites within Lithological Zone 1 for which the assumed parent material is muscovite-bearing schist. The scatterplot of $7 \AA$ peak intensities for these samples is depicted in Figure 5.8 (Top)

To facilitate analysis, a 10-site moving average curve was produced (Figure 5.8, Bottom). Although not easily seen from the scatterplot, the moving average curve reveals a tendency for the chlorite/vermiculite $7 \AA$ peak intensity ratios to decline with decreasing elevation. Pearson's correlation coefficient calculations confirm this observation. With 101 degrees of freedom, the coefficient $(r)$ is 0.44 with a calculated $p$-value of less than .005. In comparison to the mean $7 \AA$ peak intensity of 2.13 for 30 samples of muscovite-bearing schist collected in the area (Appendix B. Part 1), the fine-fraction $7 \AA$ peak intensity ratios (Figure 5.8, Bottom) indicate an apparent depletion of 

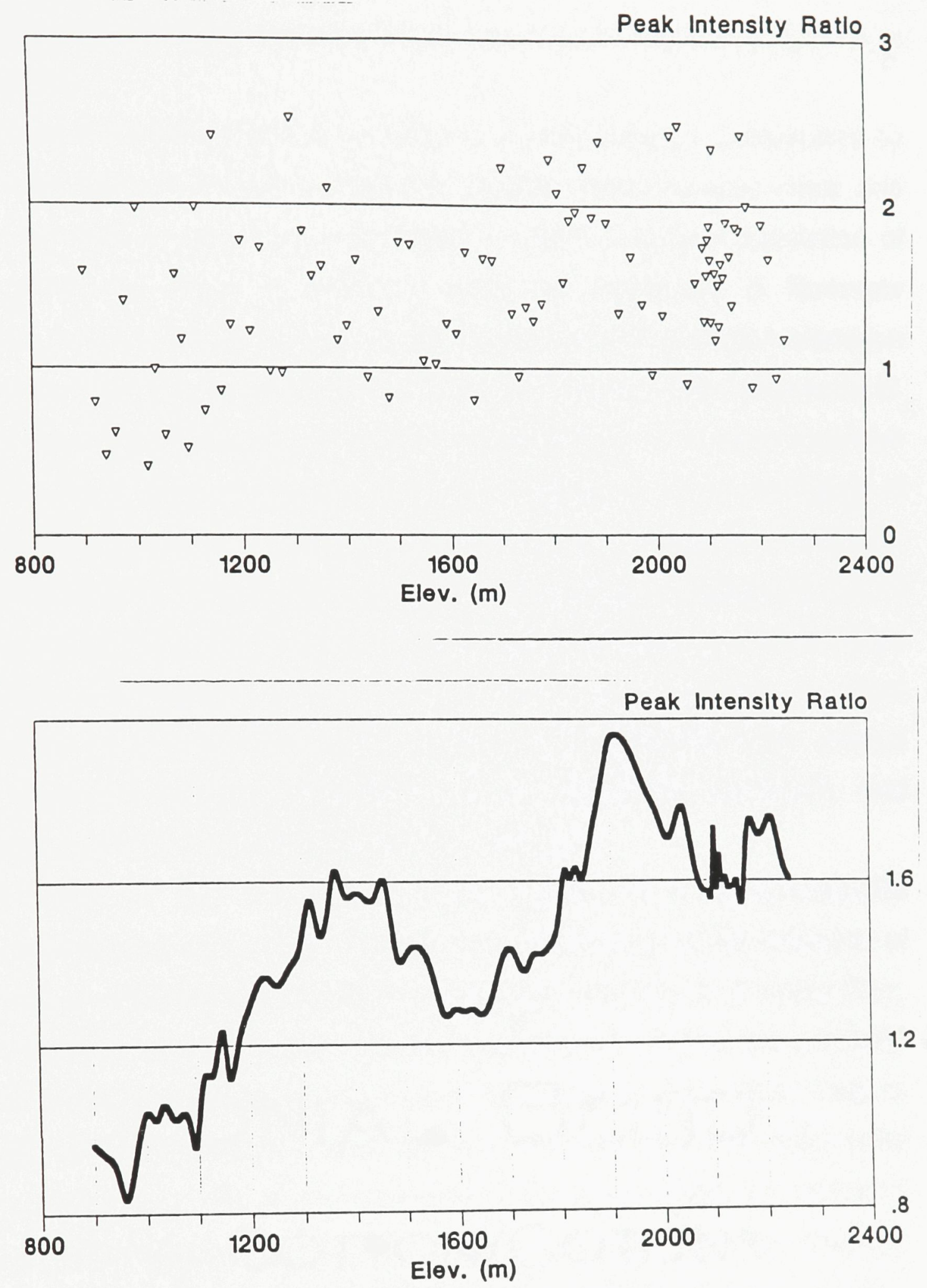

Figure 5.8: $7 \AA$ peak intensities ratios (12-peak normalization).

Top: Scatterplot for the 102 fine-fraction samples from sites where the parent material is assumed to be muscovite-bearing schist. Bottom: 10-site moving average curve for the same samples after sites were arranged in descending order of elevation. At $1900 \mathrm{~m}$ elevation, the mean peak intensity ratio is 2.13 , and, at $950 \mathrm{~m}$, it is 0.84 . 
approximately $8 \%$ at $1900 \mathrm{~m}$ elevation which increases to approximately $61 \%$ at $950 m$ elevation.

A study of the influence of slope angle and slope aspect is complicated by the previously described strong correlation between peak intensity ratios and elevation. Because of this, it was necessary to select a sample population of sites in which the effect of elevation could be minimized. A favorable combination of wide range in slope angle combined with a limited elevation range occurs in the 20 sites within the $2170-2100$ m elevation band (Appendix B, Part 4). A calculated Pearson's correlation coefficient ( $r$ ) of mineral depletion versus slope angle within this group of samples indicates a moderate degree of negative correlation with a calculated $p$-value of 0.06 for 19 degrees of freedom. A negative correlation was expected since low slope angles decrease the rate of both overland and throughflow which in turn would decrease the down-slope transportation competence of the surface-water flow resulting in local accumulations of chlorite/vermiculite. However, the relatively low $p$-value suggests that this negative correlation is only marginally significant, and therefore this evidence is somewhat less than convincing.

The case for the influence of slope aspect on chlorite/vermiculite depletion is even less convincing. As was done in the study of the influence of slope aspect on phyllosilicate alteration occurrence frequency in Chapter Four, sites were divided into two classes based on slope aspect - a "low soil-moisture" class (from south to west-facing) and a "high soil-moisture" class (from north to east-facing). In order to keep variability arising out of elevation and slope angle factors to a minimum, while at the same time ensuring an adequate degree of variability in slope aspect, sampling was restricted to sites within an elevation band of 2100 to $1800 \mathrm{~m}$ and to sites within that band whose slope angle was less than $11^{\circ}$ (Appendix $B$, Part 4). The mean fine-fraction $7 \AA$ peak intensity ratio was found to be 1.59 for low soil-moisture content sites and 1.85 for high soilmoisture content sites. A Student's $t$-test on this apparent difference produced a 

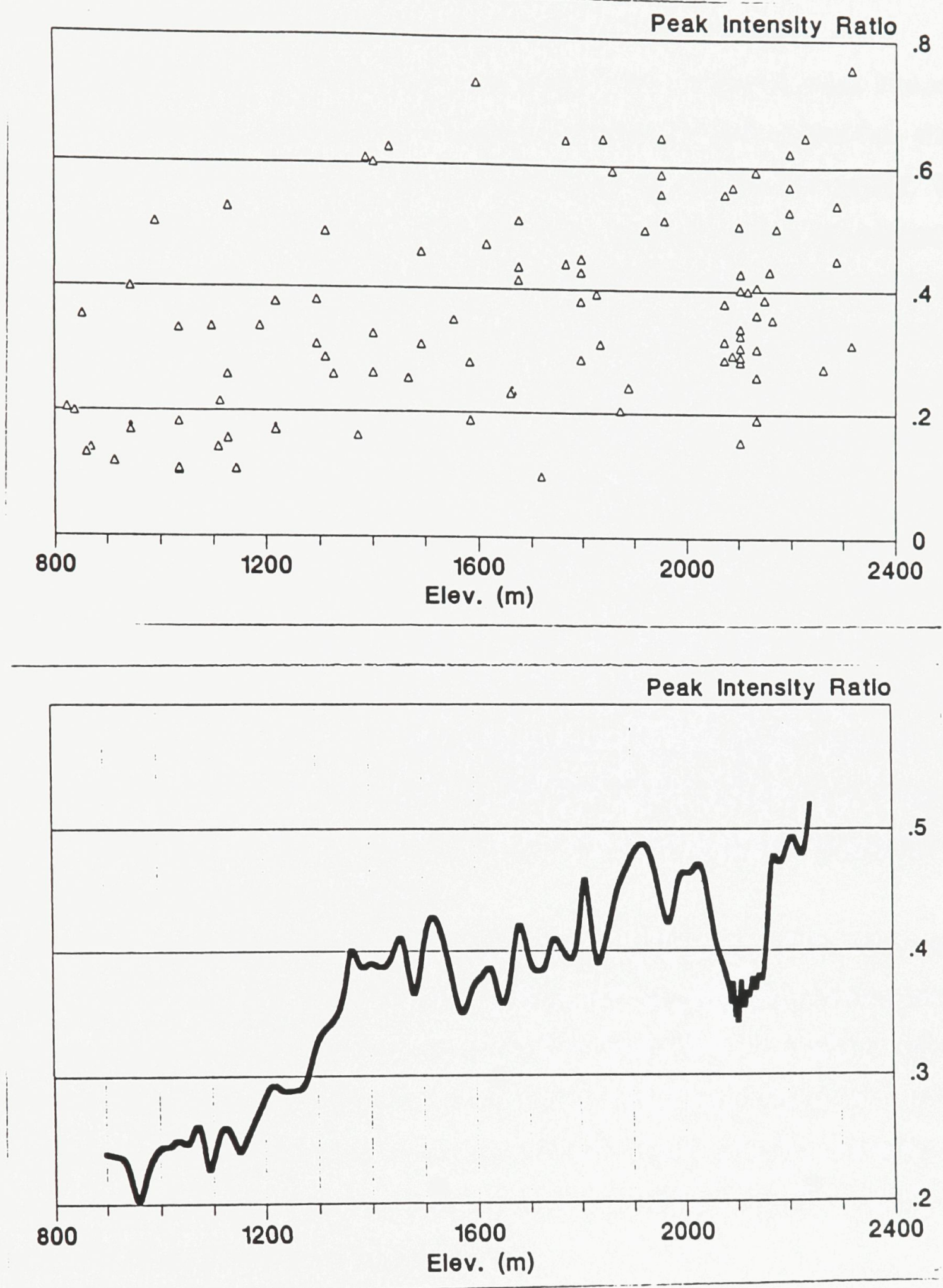

Figure 5.9: $5 \AA$ peak intensity ratios (12-peak normalization).

Top: Scatterplot for the 102 fine-fraction samples from sites where the parent material is assumed to be muscovite-bearing schist. Bottom: 10-site moving average curve for the same samples after sites were arranged in descending order of elevation. At $1900 \mathrm{~m}$ elevation, the mean peak intensity ratio is 0.48 , and, at $950 \mathrm{~m}$, it is 0.20 . 
$t$-value of -1.12 . The calculated $p$-value based on 12 degrees of freedom indicates that the difference is not significant even at the 0.14 level.

The scatterplot and 10 -site moving average curve of the $5 \AA$ peak intensity

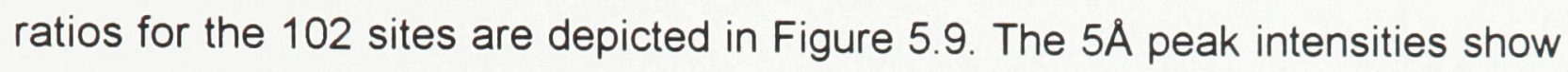
the same strong positive correlation with elevation as did the $7 \AA$ peaks. The Pearson's correlation coefficient for the $5 \AA$ peaks at 0.44 , with a calculated $p$ value of less than .005 , is identical to the $7 \AA$ coefficient. When compared to the mean $5 \AA$ peak intensity of 0.49 , for 30 samples of muscovite-bearing schist collected in the area (Appendix B, Part 1), the fine-fraction $5 \AA$ peak intensity ratios (Figure 5.9) indicate a depletion of approximately $2 \%$ at $1900 \mathrm{~m}$ elevation which increases to approximately $59 \%$ at $950 \mathrm{~m}$ elevation - the comparable figures for $7 \AA$ peak intensities were $8 \%$ at the $1900 \mathrm{~m}$ level and $61 \%$ at the $950 \mathrm{~m}$ level. The Pearson's correlation coefficient test for the relationship between $5 \AA$ peak intensity and slope angle was carried out on the same batch of samples as had been used to test the $7 \AA$ peaks ( 20 fine-fraction samples from sites between 2170 and $2100 \mathrm{~m}$ elevation). The test reveals that the correlation between $5 \AA$ peak intensity and slope angle is even weaker than was the case with $7 \AA$ peak intensity. The $5 \AA$ correlation coefficient is only -.09 which yields a calculated $p$ value of 0.36 for 18 degrees of freedom.

The test for differences in mean $5 \AA$ peak intensities between "high soilmoisture content" and "low soil moisture-content" site aspects was conducted on the same samples as had been used for the $7 \AA$ determination. The $5 \AA$ results produced a $t$-value of only -.69 which produces a calculated $p$-value of 0.36 for 12 degrees of freedom. As was the case with the $7 \AA$ peaks, this test indicates no statistically verifiable difference in mean $5 \AA$ peak intensities between "high soilmoisture and "low soil-moisture" aspect sites.

The scatterplot and 10-site moving average curve for the fine-fraction

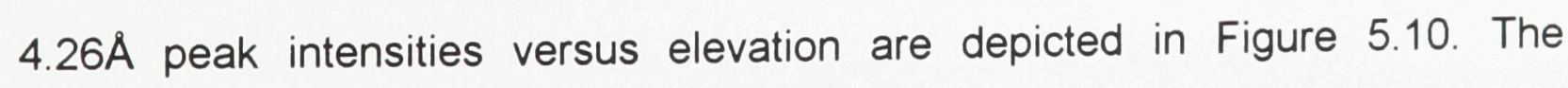
weathering-resistant quartz curve shows an inverse trend to the corresponding curves for the chlorite/vermiculite and muscovite, and as a consequence, the 

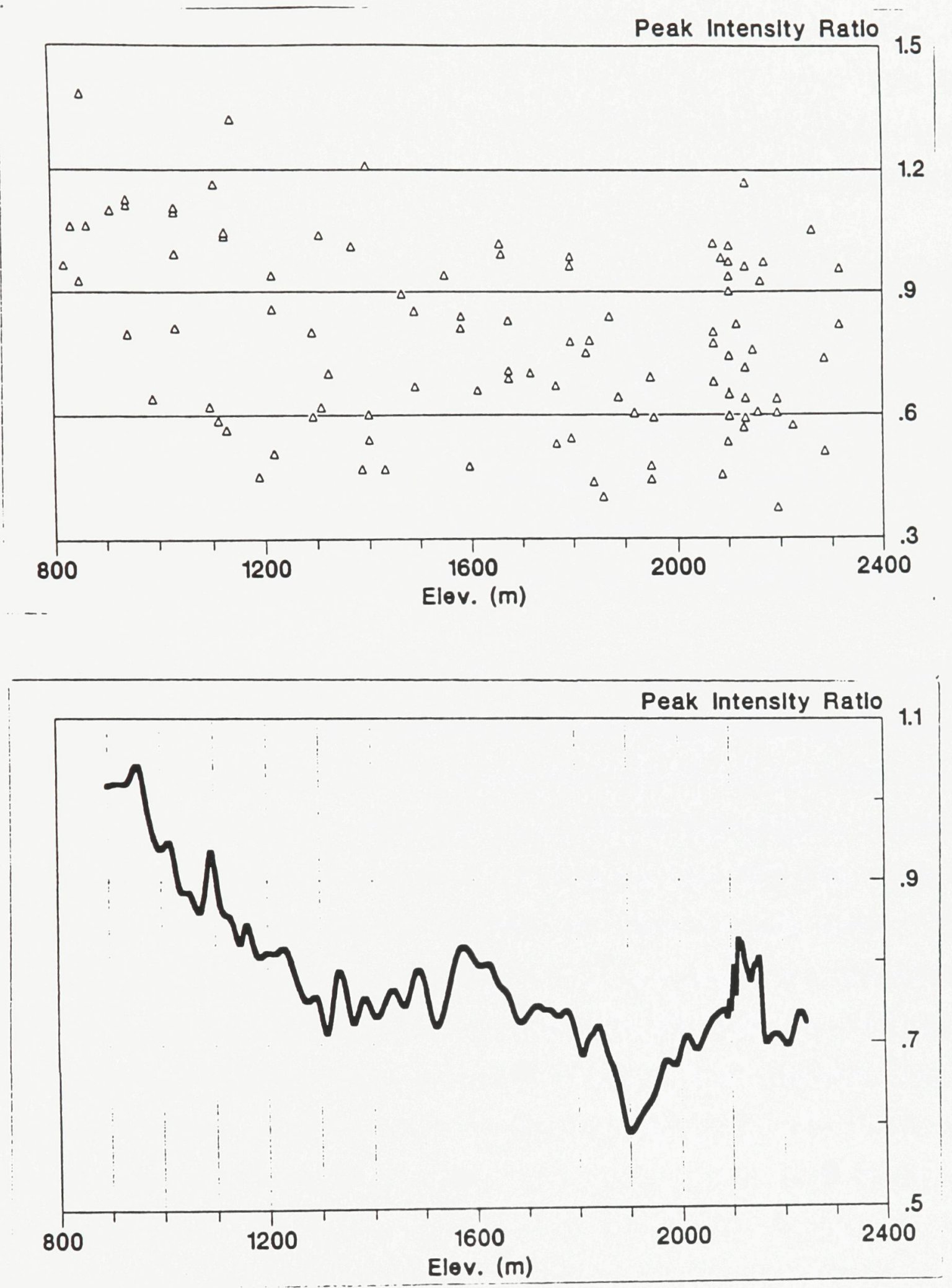

Figure 5.10: 4.26§ peak intensity ratios (12-peak normalization).

Top: Scatterplot for the 102 fine-fraction samples from sites where the parent material is assumed to be muscovite-bearing schist. Bottom: 10-site moving average curve for the same samples after sites were arranged in descending order of elevation. 
highest $4.26 \AA$ peak intensity ratios occur at the lowest elevations. There is, however, a subtle difference in the quartz curve, for unlike the chlorite/vermiculite and muscovite curves, the quartz curve, apart from local variation, indicates that there may be no meaningful correlation between quartz abundance and elevation above approximately $1300 \mathrm{~m}$ elevation, and that the anticipated negative correlation is only discernible below that point.

Calculated Pearson's correlation coefficients for all the samples collected from within the two separate elevation zones confirm this observation. For the lower elevation zone, a coefficient of -.48 with a calculated $p$-value of .006 on 25 degrees of freedom indicates a strong negative correlation. However, for the upper zone samples, the correlation coefficient is a negligible -.02 with a calculated $p$-value of 0.44 on 73 degrees of freedom indicating no significant correlation between fine-fraction quartz abundance and elevation above $1300 \mathrm{~m}$ elevation.

In order to determine if this split in the $4.26 \AA$ peak intensity trend is reflected in the 5 and $7 \AA$ peak intensity trends, correlation coefficients were recalculated for these peaks after dividing the data into two groups based on the $1300 \mathrm{~m}$ elevation boundary. Both the 5 and the $7 \AA$ data produce noticeably higher correlation coefficients for the lower elevation zone than they do for the higher zone. In the case of the $7 \AA$ peak, the data for sites below $1300 \mathrm{~m}$ elevation produce a correlation coefficient of 0.34 as opposed to a coefficient of only 0.14 for sites above $1300 \mathrm{~m}$. In the case of the $5 \AA$ peak, the coefficient is 0.22 for the lower elevation sites, but only 0.13 for the upper elevation sites. As would be anticipated, both the 5 and $7 \AA$ data produce positive correlations with elevation indicating decreasing relative abundance of the phyllosilicates at progressively lower elevations, whereas the $4.26 \AA$ data produce negative correlations with elevation indicating increasing relative enrichment of the quartz.

Field observations suggest that there may well be real (as opposed to merely apparent) quartz enrichment within the lower elevation zone. As 
discussed in Chapter 3, seven terrace-like fragments were found within the St. Elias and Nisling ground surface zones. The field evidence suggests that these features are probably remnants of ice marginal contact features in which sorting by meltwater runoff has resulted in the deposition of quartz-rich sand. If this is so, then the post-glacial erosion of these features would have spread this quartz-rich material down-slope with the heaviest concentrations occurring in the valley bottoms.

Central to the above explanation is the premise that the observed trends result from real quartz enrichment rather than from real phyllosilicate (chlorite/vermiculite and muscovite) depletion. Although it would be difficult if not impossible to directly differentiate between real and apparent quartz enrichment by the investigative means employed in this study, it is possible inferentially to differentiate between real and apparent phyllosilicate depletion using the existing data, and this can indirectly verify the existence of real quartz enrichment.

It has already been established that below $1300 \mathrm{~m}$ elevation there are credible positive correlations between elevation and both 5 and $7 \AA$ peak intensity ratios. If these correlations reflect real phyllosilicate depletion, then (since the depletion rates of chlorite/vermiculite and $7 \AA$ are different from one another) the ratio between chlorite/vermiculite and muscovite peak intensities in other words, $(7 \AA 5 \AA \AA)$ - should diverge down-slope and result in a significant positive correlation between this divergence and elevation. Consequently two such correlation calculations were conducted on the $7 \AA / 5 \AA$ ratio divergences.

The first of these was for all 102 sites within the muscovite-bearing schist zone. The Pearson's correlation coefficient of 0.13 indicated near random distribution with respect to elevation. A second coefficient was calculated for the 27 sites below $1300 \mathrm{~m}$ elevation only. The coefficient in this case at 0.16 also indicated near random distribution. The near-random distribution of the $7 \AA / 5 \AA$ ratio divergence above $1300 \mathrm{~m}$ was expected in view of the observed lack of trend in quartz abundance in the upper elevation zone. However, the strong 
negative correlation between the $4.26 \AA$ peak intensity ratio and elevation in the zone below $1300 \mathrm{~m}$ coupled with the near random $7 \AA / 5 \AA$ ratio divergence in the same zone, indicates by inference that the observed quartz enrichment is real rather than apparent.

However, establishing that real quartz enrichment controls the correlation below $1300 \mathrm{~m}$ elevation does not eliminate the possibility that some lesser degree of real phyllosilicate depletion also exists. In fact in sites above the $1300 \mathrm{~m}$ elevation level, the indicated phyllosilicate depletion differential (as derived from data provided in Table 5.11) between chlorite/vermiculite on one hand and muscovite on the other averages approximately $11 \%$ indicating that the depletion is real. However, in sites below $1300 \mathrm{~m}$ elevation, any real depletion is insufficient in magnitude to exert a noticeable effect on correlations between phyllosilicate content and elevation.

In light of this evidence, it would be useful at this point to re-examine the anomalous ground-surface-zone mean-peak-intensity ratios reported in the chronosequence analysis section of this paper. The two phyllosilicate ratios given in Table 5.9 indicated that these minerals were apparently more depleted in the younger St. Elias Ground Surface Zone than they were in the older Ruby Ground Surface Zone, and the corresponding quartz ratios indicated that this mineral was apparently more enriched in the St. Elias zone than in the Ruby zone. The interzonal differences for all three of these pairs of ratios were found to be statistically significant at the 0.05 level (Table 5.10).

What was not discussed in the chronosequence analysis was that there is evidence that both these ground surfaces contain quartz-rich and phyllosilicatepoor ice marginal contact deposits. With time, these deposits would become adulterated by freshly weathered bedrock material thereby restoring some of the phyllosilicate content and reducing the relative abundance of the quartz component. This trend would be more exaggerated on the older Ruby surfaces, and it is entirely possible that this could produce the twin anomalies of high phyllosilicate ratios and low quartz ratios relative to the younger St. Elias 

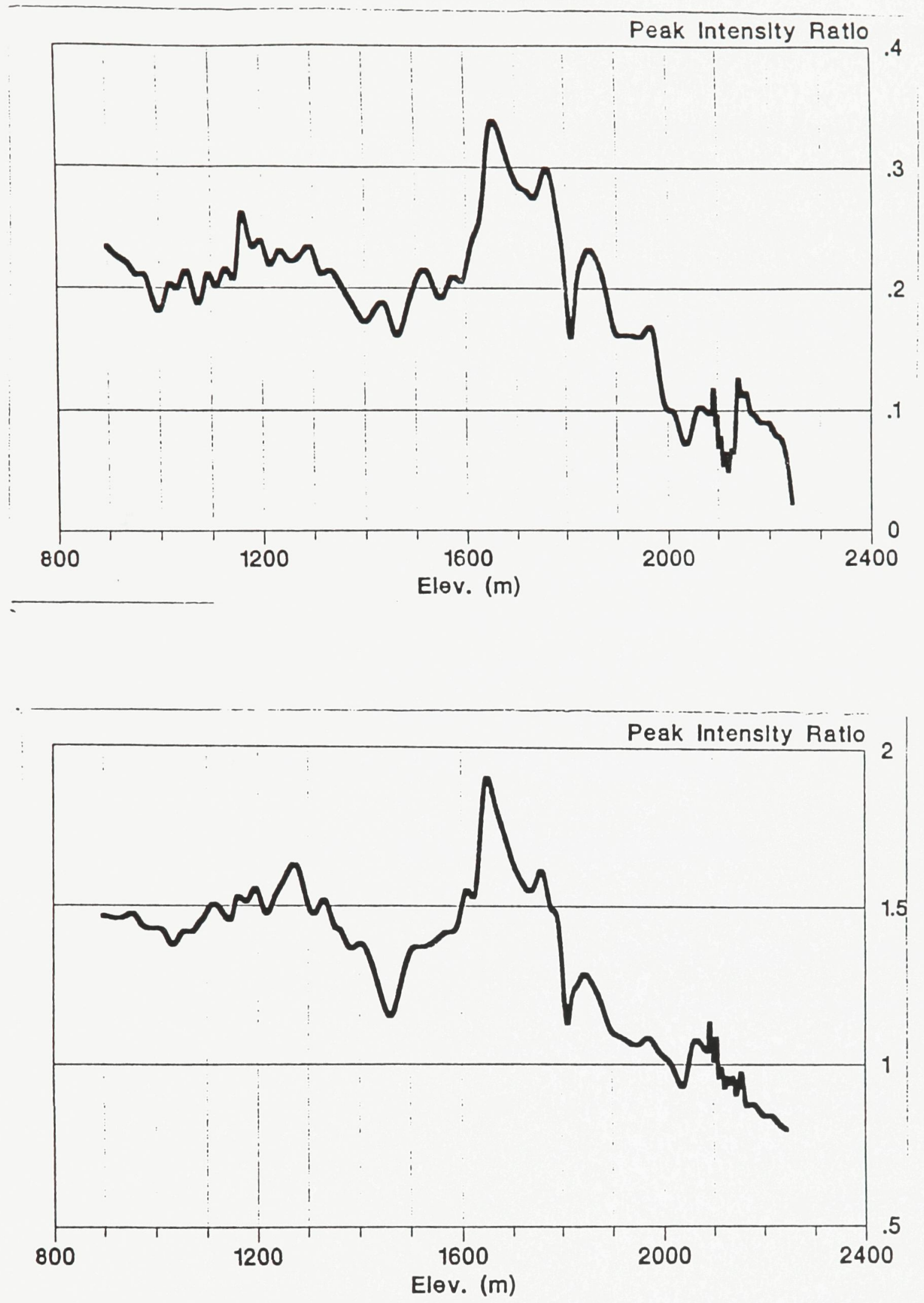

Figure 5.11: 8.4 and $3.19 \AA$ fine-fraction peak intensity ratios (12-peak normalization).

Top: 10 -site moving average curve for $8.4 \AA$ fine-fraction peak intensity ratios versus elevation. Bottom: 10 -site moving average curve for $3.19 \AA$ fine-fraction peak intensity ratios versus elevation. Note the striking similarity of the two curves. 
surfaces. As a result of this, a false impression would be given of more advanced weathering on the younger surface.

Figure 5.11 depicts the 10 -site moving average curves for both the $8.4 \AA$ (Top) and $3.19 \AA$ (Bottom) peak intensity ratios versus elevation. The striking similarity between the two graphically confirms the partial correlation calculations reported in the previous section on volcanic ash additions which indicated that the relative abundance of these two minerals, amphibole and feldspar, are closely correlated due to the fact that they are both major components of the volcanic ash which was deposited in the area. Both curves depict the current distribution pattern for the ash deposits. From very low relative abundance levels at the highest elevations, the ash content increases to reach peak abundance at approximately $1650 \mathrm{~m}$ elevation. From $1600 \mathrm{~m}$ elevation downwards, however, the ash component of the fine-fraction materials remains fairly constant at a slightly lower relative abundance level. This close association of feldspar abundance with fine-fraction volcanic ash content precludes any possibility of estimating feldspar depletion through weathering.

\subsubsection{Relative Weathering - Muscovite versus Biotite}

The presence of both muscovite and biotite-bearing schist parent material in Lithological Zone 1 presents an opportunity to examine relative weathering rates of these two mica species. Transect $1 \mathrm{~K}$ contains 10 sites on a single northsouth summit ridge between 2070 and $2285 \mathrm{~m}$ elevation in which the assumed parent material is muscovite-bearing schist. Transect $1 \mathrm{~L}$ contains 9 sites on a single north-south summit ridge between 2070 and $2320 \mathrm{~m}$ elevation in which the assumed parent material is biotite-bearing schist. Transect $1 \mathrm{~L}$ lies less than 5 $\mathrm{km}$ to the east of Transect $1 \mathrm{~K}$. Proximity, parallel orientation, and a shared elevation range suggest that micro-climate conditions are nearly identical on the two transects, thereby affording a unique opportunity to assess the relative weathering performance of these two mica species under these conditions. 
The 10 fine-fraction samples containing muscovite from Transect $1 \mathrm{~K}$ produced a mean $10 \AA$ peak intensity ratio of 0.937 , whereas 7 bedrock samples from the same transect produced a mean $10 \AA$ peak intensity ratio of 0.970 . Assuming that a decline in the peak intensity ratio gives a reasonable approximation of mineral depletion, then the indicated depletion of muscovite in fine-fraction materials on Transect $1 \mathrm{~K}$ is in the order of $3.4 \%$. This figure is much lower than that obtained by comparing the mean $10 \AA$ peak intensity ratio of the 9 fine-fraction samples on Transect $1 \mathrm{~L}$ to 6 biotite-bearing schist bedrock samples from the same transect. In this case, when the mean fine-fraction peak intensity ratio of 0.82 is compared to the mean bedrock peak intensity ratio of 3.25 , biotite depletion in the order $74.8 \%$ is indicated.

Although this indicated biotite depletion rate may appear extreme, it must be noted that not all this "vanishing" biotite has been physically removed from the site. In fact, as was described in Chapter Four, a proportion of the weathered mica (muscovite as well as biotite) remains within the fine-fraction in the form of hydrated and interstratified clay minerals. The extent of the weathering can be estimated by measuring the cross-sectional area under the broad peak ("plateau") that appears between $10 \AA$ and $14 \AA$ on fine-fraction X-ray diffraction records.

Since there is no evidence to suggest that there is any difference in the ages of the surfaces of these transects, one must assume that under the periglacial conditions of the study area, biotite weathers much more readily than muscovite. This relative instability of biotite under periglacial conditions may well explain why such advanced weathering features as large weathering pits, tor formations, and excessive accumulations of grus appear on certain transects in Lithological Zone 2 and not on others. In Zone 2, these advanced weathering features were found only on Transect 2A, 2B and parts of Transect 2D. The one common feature of these sites on which advanced weathering occurs is that the felsic bedrock contains a substantial amount of biotite. On sites where the bedrock lacks substantial biotite, these advanced weathering features are 
missing. Therefore, the assumption was incorrect that the advanced weathering features encountered during the initial reconnaissance indicated surfaces of great age.

\subsection{SUMMARY}

The variability in the mineral abundance of Lithological Zone 2 bedrock precluded an analysis of mineral depletion on the Zone 2 transects using the investigative methods adopted for this study. Therefore, the conclusions reached concerning fine-fraction mineral depletion within the study area are based on samples collected within the confines of Lithological Zone 1, where the bedrock mineral abundance was found to be sufficiently homogeneous to permit a statistically validated analysis. As a result of this, the range of minerals potentially available for study was confined to chlorite/vermiculite, muscovite, biotite, quartz and plagioclase feldspar. The addition of parent material in the form of aeolian-transported volcanic ash resulted in the elimination of feldspar depletion from the study. Similarly the addition of loess to the fine-fraction created complications for an analysis of mineral depletion at sites located in the Post-glacial Ground Surface Zone. The probable effect of the addition of loess on the analysis would be to overstate mica depletion and to understate the relative quartz enrichment at the affected sites.

The chronosequence model developed for this study predicts fine-fraction depletion rates for both chlorite/vermiculite and muscovite should be highest in the oldest (Pre-Nisling) ground surface zone, and sequentially lower in each chronologically successive zone. The analysis of the samples, however, indicated that there is little difference between depletion rates on Pre-Nisling, Nisling and Ruby surfaces. The only significant differences found were between the depletion rates of this group of surfaces and the newer St. Elias and Postglacial surfaces, and in both these cases, the newer surfaces actually had higher depletion rates. 
It is concluded, therefore, that the postulated chronosequence model fails to explain the mineral depletion pattern in the study area fine-fraction. One possible reason for this is that freshly weathered bedrock material is being continually added to the fine-fraction. The evidence for this lies in the abundance of fresh mica-schist chips in the 2 to $5 \mathrm{~mm}$ range found while sieving fine-fraction samples.

When the 102 muscovite-bearing schist sites were grouped together regardless of transect, and arranged according to elevation, it was found that there was a strong positive correlation between fine-fraction phyllosilicate depletion and elevation. The range of indicated depletion rates for chlorite/vermiculite ( 8 to $61 \%$ ) was found to be slightly higher than the range of indicated depletion rates for muscovite (2 to 59\%). The higher indicated depletion rates for chlorite/vermiculite relative to the rates for muscovite were predictable in view of the known weathering stability characteristics of the minerals involved. However, tests for the anticipated influence of slope angle and slope aspect on mineral depletion proved inconclusive.

It was anticipated that the relative abundance of fine-fraction quartz would demonstrate a reciprocal to that of the phyllosilicate fine-fraction, i.e., that quartz would demonstrate a trend to declining relative abundance with decreasing elevation. The tests, however, indicate a different pattern. Sites above $1300 \mathrm{~m}$ elevation proved to lack a significant correlation between relative quartz abundance and elevation, whereas a strong trend towards relative enrichment with lower elevation was found in sites below $1300 \mathrm{~m}$. Further tests indicated that this enrichment was real rather than apparent suggesting that additional quartz had been added to the fine-fraction at lower elevations. A possible explanation for this lies in the presence of what is believed to be relict quartz-rich ice marginal contact materials which are found in the lower elevation range.

In addition, adulteration by freshly weathered fines from local bedrock outcrops may account for the observed anomalous indication of relative age between the Ruby and St. Elias ground surface zones. In this case, the older 
Ruby surfaces would have accumulated more adulterating phyllosilicate-rich fines over time as a result of local bedrock weathering than the more recent St. Elias surfaces. The resulting adulteration of the quartz-rich sandy glacial deposits could well result in a relatively phyllosilicate-rich balance on the Ruby surfaces and a relatively quartz-rich balance on the St. Elias surfaces.

Detectable amounts of loess identified through the characteristic $3.03 \AA$ calcite peak were found in the fine-fraction samples at 3 out of 6 sites below $970 \mathrm{~m}$ elevation in the Cultus Creek valley, and further west at 2 out of 5 sites in the Jarvis River valley below 1040 m elevation. The most probable source of the loess in the Cultus Creek valley is from sediments deposited by the Kaskawulsh Glacier in the Slim's River Valley. This source lies approximately $20 \mathrm{~km}$ upwind from the Cultus Creek sites. Possible sources of loess in the Jarvis River valley sites are sediments deposited by the St. Elias lobe which advanced up the valley and into the study area from the southeast, or alternatively from a second St. Elias lobe which advanced into the Kluane Lake basin from the south, and, at its maximum, extended into Cultus Bay.

It has been established in this study that the presence of amphibole in the Lithological Zone 1 fines indicates the presence of volcanic ash, and that there is a close correlation in the study area fines between amphibole and plagioclase feldspar indicating the ash is also a major contributor of the feldspar in these fines. Therefore, the relative abundance of these two minerals in the fine-fraction minerals is considered indicative of the present distribution of the ash within the study.

From very low relative abundance levels at the highest elevations, the ash content increases to reach peak abundance at approximately $1650 \mathrm{~m}$ elevation. From $1600 \mathrm{~m}$ elevation downwards, however, the ash component of the fine-fraction materials remains fairly constant at a slightly lower relative abundance level. One possible explanation for this is that there was probably fairly rapid early transportation of the ash down-slope until its progress was retarded by vegetation, and it subsequently became incorporated into the 
existing fine-fraction. A second possible explanation is that the distribution pattern was dictated by the aeolian transport capability during deposition.

The presence of both muscovite and biotite-bearing schist parent material in Lithological Zone 1 at sites under nearly identical microclimate conditions presented an opportunity to examine relative weathering rates of these two mica species. The indicated depletion rate for muscovite at these sites was $3.4 \%$ whereas for biotite it was found to be much higher at $74.8 \%$. This indicated relative instability of the biotite under periglacial conditions may well explain why such advanced weathering features appear on certain transects and not on others. These advanced weathering features were found only on sites at which the felsic bedrock contains an abundance of biotite. Therefore, the assumption that the advanced weathering features encountered during the initial reconnaissance indicated surfaces of great age was incorrect. 


\section{IRON OXIDE DISTRIBUTION}

\subsection{INTRODUCTION}

During the course of this study, an offer was made by Dr. C. Wang of the Land Resource Research Center, Agriculture Canada, to have free-iron extractions performed on a limited number of fine-fraction samples by the Center's technical staff. The use of "free-iron" (non-silicate iron) content to determine the age of fine fraction materials is an accepted practice. This method has been employed in other studies (Bockheim, 1979; McKeague et al., 1983; Birkeland, 1984; Wang et al., 1986) in which the regolith had developed under cold climate conditions. For the purposes of this study, a total of 62 samples were selected to ensure equitable distribution throughout the five ground surface zones, but within each ground surface zone, samples were selected on a random basis from sites within Lithological Zone 1.

\subsubsection{Formation of Iron oxides}

"Free-iron" is extractable from the following pedogenic oxides: goethite $(\alpha-\mathrm{FeOOH})$, lepidocrocite $(\gamma-\mathrm{FeOOH})$, feroxyhyte $\left(\delta^{\prime}-\mathrm{FeOOH}\right)$, akaganeite $(\beta-$ $\mathrm{FeOOH})$, hematite $\left(\alpha-\mathrm{Fe}_{2} \mathrm{O}_{3}\right)$, maghemite $\left(\gamma-\mathrm{Fe}_{2} \mathrm{O}_{3}\right)$, magnetite $\left(\mathrm{Fe}_{3} \mathrm{O}_{4}\right)$ and amorphous ferrihydrite $\left(\mathrm{Fe}_{5} \mathrm{HO}_{8} .4 \mathrm{H}_{2} \mathrm{O}\right.$ ) (Schwertmann and Fitzpatrick, 1992). As part of the fine-fraction weathering process, these oxides commonly take the form of either surface coatings on other minerals or as discrete, colloidal particles in clusters or aggregates (Torrance, 1999, personal communication). Of these oxides, it is commonly accepted that the principal ones formed during finefraction weathering are hematite and goethite. Schwertmann (1988) maintained 
that the primary reaction through which $\mathrm{Fe}$ (III) oxides are introduced into the pedogenic cycle is the hydrolytic and oxidative decomposition of lithogenic $\mathrm{Fe}(\mathrm{II})$, and in pedoenvironments this reaction is considered irreversible.

The relative abundance of hematite and goethite are functions of temperature and humidity. In a study of Alfisols on Guadalquivir River terraces in Spain, Pena and Torrent (1984) found hematite only in well-drained soils and in some A horizons of imperfectly-drained soils, but poorly-drained soils contained only goethite. That soil moisture content is one of the controlling factors in the hematite to goethite ratio, is supported by laboratory work in which Torrent et al. (1982) demonstrated that with decreasing relative humidity, the rates of ferrihydrite transformation to hematite and goethite slow down, and that the ratio of hematite to goethite changes from favoring goethite at $100 \%$ relative humidity to favoring hematite below about $98 \%$ relative humidity. They also found that the ratio of hematite to goethite declines rapidly with temperature.

The hematite to goethite ratio may also be influenced by the presence of organic matter. Schwertmann (1971) postulated that organic matter will complex with inorganic $\mathrm{Fe}$ cations in soil solution, thereby lowering the activity of inorganic Fe (III) ions in solution. This would prevent the solubility product of ferrihydrite, but not the much lower one of goethite, from being exceeded. Because Schwertmann (1971) maintained that ferrihydrite is an essential precursor of hematite but not of goethite, he argued that, under these circumstances, only goethite would be formed. He admitted, however, that this hypothesis is difficult to verify experimentally because many organics strongly inhibit goethite crystallization in short-term experiments. In addition, Lindsay (1988) has found that the solubility of $\mathrm{Fe}^{3+}$ oxides increased at lower soil $\mathrm{pH}$, and thus organic matter may also affect the overall level of iron oxide accumulation by altering soil $\mathrm{pH}$.

It can be anticipated that all these factors would influence the accumulation of iron oxides in the northwest Ruby Range fine fraction to one extent or another. The climate regime of the study area is both cold and semi- 
arid as indicated by the mean annual temperature of $-6^{\circ} \mathrm{C}$ and mean annual precipitation of $240 \mathrm{~mm}$ at Burwash Landing $(20 \mathrm{~km}$ west of the study area at an elevation of $689 \mathrm{~m}$ ), the closest weather station for which reliable data exist (Environment Canada, 1996). Comparable conditions would lead to low overall rates of iron oxide production which, at any locale within the study area, could be influenced by the dominant ground cover. In terms of the hematite to goethite ratio, the semi-arid precipitation regime and the low mean annual temperature regime would work against one another.

\subsubsection{Iron Oxide Benchmarks}

A literature review revealed a number of studies concerning the correlation between pedogenic iron oxide abundance and the age of the host fine fraction in both temperate and cold climate regions. It was anticipated that data from these studies could provide benchmark guidance for estimating the age of fine-fraction deposits within the Northwest Ruby Range study area. However, none of these studies proved to be helpful in this regard. One of these, a study by Wang et al. (1986) of the iron oxide content of soils developed on Nova Scotian tills was rejected out of concern that the multi-horizon stratigraphy of these soils would yield data that were inapplicable to the single-horizon finefraction deposits common to most sites in the Northwest Ruby Range study area. An additional concern was that the warmer and damper maritime climate of Nova Scotia would have resulted in a different rate of iron oxide accumulation. Similar considerations of climate and stratigraphy led to elimination of a study by McKeague et al. (1983) on the iron oxide contents of tills and saprolites in the Cape Breton Highlands. A study by Bockheim (1979) of iron oxides in soils which had developed on reliably dated tills from the Wright Valley, Antarctica, was also eliminated because the extracted iron of soils as old as 920,000 years was an order of magnitude lower than that of any sample examined in this study. Birkeland (1984) provided data on the distribution of pedogenic iron in soil parent materials estimated to be about 10,000 years old from various alpine and 
arctic sites whose temperature and precipitation regimes are comparable to those of the northwest Ruby Range study area. However, these data are unusable in the current study because Birkeland's (1984) "free iron" contents were all estimated by the acid ammonium-oxalate extraction method - a process which extracts very little of the hematite and goethite (McKeague and Day, 1966; Chao and Zhou, 1983; Sheldrick, 1984).

\subsection{INVESTIGATIVE PROCEDURES}

\subsubsection{Iron Oxide Extraction Methods}

Fine-fraction iron oxides are commonly extracted by one of four dissolution methods: acid ammonium oxalate, acidified hydroxylamine hydrochloride, Tiron (catecholdisulphonic acid di-sodium salt), and dithionitecitrate. Each of these affords a different degree of selectivity and limitation. The acid ammonium oxalate method, which was used in studies reported by Birkeland (1984) and discussed briefly in Section 6.1.2 of this paper, dissolves amorphous iron oxides such as ferrihydrite, but only slightly attacks hematite and goethite (McKeague and Day, 1966; Chao and Zhou, 1983: Sheldrick,1984).

The acidified hydroxylamine hydrochloride method also extracts iron from amorphous oxides (Chao and Theobold, 1976; Chao and Zhou, 1983; Chao, 1984), and is recommended as an alternative to the acid ammonium oxalate method (Wang et al., 1987). The Tiron method is used to extract iron oxides from alkaline soils where $\mathrm{pH} \geq 10.5$ (Biermans and Baert, 1977; Kodama and Ross, 1991; Ross, 1993). In addition, small amounts of $\mathrm{Fe}$ are reported to be extracted from both goethite and hematite (Kodama and Ross, 1991) with this procedure. In the case of the dithionite-citrate method, the degree of extraction is dependent on grain size. Large crystals of goethite and hematite are only partly dissolved (McKeague and Day, 1966). Ross and Wang (1993) reported that dithionite-citrate removes finely divided hematite, goethite, lepidocrocite, ferrihydrite and noncrystalline iron oxides as well as organic-complexed $\mathrm{Fe}$, 
while extracting virtually no Fe from most crystalline silicate minerals. Therefore, they concluded, this method provides a reliable estimate of "free" (nonsilicate) $\mathrm{Fe}$ in soils.

On the basis of the reported characteristics of these four extraction methods, it was considered that dithionite-citrate iron extract would provide the most reliable estimate of fine-fraction iron oxide content for the study area samples. Dithionite-citrate extraction offers the best potential for estimating combined hematite, goethite and ferryhydrite content, and, as mentioned in Section 6.1 .1 of this chapter, it was anticipated that these three would comprise the main iron-oxide weathering products. Support for this decision is provided by Borggaard (1988) who has stated that dithionite-citrate-extractable $\mathrm{Fe}$ is a fair estimate of pedogenic $\mathrm{Fe}$ oxides in soils and clays.

One possible exception to the above statement would be the case in which these oxides form large, discrete grains. However, as described in Chapter 5, all the mounted specimens prepared for the relative mineral abundance study were examined by optical microscopy, and large, discrete grains of iron oxides were detected in none of the specimens. In addition, none of the X-ray diffraction records from this study revealed detectable amounts of either hematite or goethite. It is improbable that the large, discrete grains of these minerals could completely escape detection by both optical microscopy and $\mathrm{X}$-ray diffraction .

\subsubsection{Dithionite-Citrate Extraction Procedures}

The procedures used for the dithionite-citrate extraction were as follows: $0.5 \mathrm{~g}$ of fine fraction $(\phi<2 \mathrm{~mm})$ material that had been ground to pass a 35-mesh sieve was poured into a $50 \mathrm{~mL}$ plastic centrifuge tube. Using a repipet dispensing bottle, $25 \mathrm{~mL}$ of sodium citrate solution was added. A calibrated scoop was used to add about $0.4 \mathrm{~g}$ of dithionite $\left(\mathrm{Na}_{2} \mathrm{~S}_{2} \mathrm{O}_{4}\right)$. The centrifuge tubes were then stoppered and shaken end-over-end overnight. The stoppers were removed and the tubes were centrifuged for 15 minutes at 500G. The centrifugate was saved 
in plastic containers. Extracts containing suspended material were filtered and the extracts diluted ( $1 \mathrm{~mL}$ of extract and $4 \mathrm{~mL}$ of distilled water) to give a convenient concentration. Standard solutions containing iron were prepared in the diluted extracting solution. Sodium dithionite was dissolved in this solution $(3.2 \mathrm{~g} / \mathrm{L})$ and gently heated. Standard solutions of iron were made to volume with this solution after it cooled. Iron determination was made by atomic absorption spectroscopy using an air-acetylene flame.

It is maintained that, in following these procedures, the Land Resource Research Analytical Service Laboratory consistently produces results in which the coefficients of variation of iron at levels of $0.67 \%$ is $7.2 \%$ (Ross and Wang, 1993).

\subsection{RESULTS}

\subsubsection{Chronosequence Evaluation}

In order to test the chronosequence hypothesis, the entire 62 samples which had been selected for dithionite-citrate extraction were used to determine the mean extracted-iron levels of individual ground surface zones (Table 6.1).

Table 6.1: Mean Extracted Iron by Ground Surface Zone

\begin{tabular}{|c|c|}
\hline Ground Surface Zone (n) & Mean Extracted Iron (\%) \\
\hline Pre-Nisling (12) & 1.88 \\
\hline Nisling (13) & 1.12 \\
\hline Ruby (14) & 1.18 \\
\hline St. Elias (11) & 1.22 \\
\hline Post-glacial(12) & 0.93 \\
\hline
\end{tabular}

The Student's $t$ test was applied to these data to determine the statistical significance of the interzonal differences. The rejection level was arbitrarily set at $>0.05$. The results of these tests are summarized in Table 6.2. 
Table 6.2: Student's $t$ Tests of Extracted Iron Distribution by Ground Surface Zones

\begin{tabular}{ccc} 
Zones & $p_{\text {calc }}$ & $d f$ \\
Pre-Nisling vs. Nisling & $<.01$ & 23 \\
Nisling vs. Ruby & 0.54 & 25 \\
Nisling vs. St. Elias & 0.30 & 23 \\
Ruby vs. St. Elias & 0.70 & 21 \\
St. Elias vs. Post-glacial & 0.02 & 24 \\
Ruby vs. Post-glacial & $0.04^{\circ}$ & 22 \\
\hline
\end{tabular}

*Significant at .05 level

The fact that the mean extracted-iron levels of the Pre-Nisling samples is significantly higher than that of the Nisling samples is consistent with the chronosequence hypothesis. However, there is no statistically significant difference between the mean extracted-iron levels of the Nisling, Ruby and St. Elias samples which is clearly inconsistent with this hypothesis. At the same time, both the Ruby and St. Elias samples have significantly higher extractediron levels than the Post-glacial deposits down-slope from them. This relationship between the extracted-iron levels of the Ruby and St. Elias samples and those of the Post-glacial samples would be consistent with the additional materials hypothesis because, as discussed in Chapter 5 , the Post-glacial deposits are relatively quartz-rich. A higher (iron-free) quartz component in all likelihood results from the depletion of the iron-rich chlorite from the parent material, and this could be the reason for the overall low extracted-iron levels in the Post-glacial deposits.

\subsubsection{Topofactor Evaluation}

In addition, the relationships between extracted-iron levels and the topofactors of elevation, slope angle, slope aspect, and predominant ground cover were examined to determine if any of these factors could be identified as having had a significant influence on the extracted-iron distribution pattern. 


\subsubsection{Extracted Iron and Elevation}

Pearson's product moment correlation coefficient data which were calculated to establish the statistical significance of the relationship between extracted-iron levels and elevation are summarized in Table 6.3.

Table 6.3 : Extracted Iron and Elevation Correlations

\begin{tabular}{|c|c|c|c|}
\hline & r & $\mathrm{N}$ & $\begin{array}{c}p_{\text {calc }} \\
\text { (2-tail) }\end{array}$ \\
\hline $\begin{array}{c}\text { All transects included } \\
\text { Pre-Nisling and Post-alacial sites }\end{array}$ & 0.59 & 50 & $<.01$ \\
\hline excluded & -0.33 & 33 & 0.05 \\
\hline
\end{tabular}

When the samples from all transects are included, a moderately strong correlation with elevation is indicated. It should be further noted that, when the Pre-Nisling and Post-glacial samples are excluded, the correlation for the midslope sites actually turns weakly negative which would be consistent with expectations for mid-hillslope surface conditions under the influence of a normal vertical air temperature gradient.

\subsubsection{Extracted Iron and Slope Angle}

A Pearson's product moment correlation coefficient was calculated to evaluate the relationship between free iron distribution and slope. The results $\left(r=0.05, N=50\right.$ and $p_{\text {calc }}(2$-tail $\left.)=0.74\right)$ indicate that there is no statistically significant correlation between extracted-iron level and slope angle.

\subsubsection{Extracted Iron and Slope Aspect}

Using the same rationale as was outlined in Chapter 5 for differentiating between "high-evaporation" and "low-evaporation" sites, i.e., slope aspects from southeast to west are classified as high-evaporation sites, and those with slope aspects from northwest to east are classified as low-evaporation sites, a Student's $t$-test was conducted to evaluate the statistical difference between the mean extracted-iron levels of those two groups of sites. The mean extracted-iron data are tabulated in Table 6.4. 
Table 6.4: Summary of Mean Extracted-Iron Level by Slope Aspect

\begin{tabular}{ccc} 
Aspect & Mean Extracted Iron $(\%)$ & Sites $(n)$ \\
\hline "High-Evaporation" & 1.14 & 34 \\
"Low-Evaporation" & 1.12 & 6
\end{tabular}

The Student's $t$ (two-tail) tests indicate that any differences in mean extractediron levels between "high" and "low evaporation" sites are insignificant at the 0.05 level $\left(p_{\text {calc }}=.92\right.$ with $\left.d f=38\right)$.

\subsubsection{Extracted Iron and Ground Cover}

The mean extracted-iron levels for each ground cover class are tabulated in Table 6.5. Relatively high values occur for the felsenmeer- and tundradominated sites, but a low value is indicated for that group of sites in which the predominant ground cover is floodplain grass.

Table 6.5: Mean Extracted-Iron Level (\%) by Ground Cover Class

\begin{tabular}{|c|c|c|}
\hline Ground Cover Class & Mean Extracted Iron (\%) & Sites (n) \\
\hline Felsenmeer & 1.40 & 5 \\
\hline Tundra & 1.40 & 11 \\
\hline Willow & 1.11 & 9 \\
\hline Aspen & 1.15 & 16 \\
\hline Spruce & 1.35 & 7 \\
\hline Floodplain Grass & 0.51 & 5 \\
\hline
\end{tabular}

Student's $t$ - tests conducted on the mean iron levels are summarized in Table 6.6. Only the mean value differences between spruce and floodplain grass classes of samples are statistically significant at the 0.05 rejection level.

Table 6.6: Student's $t$ Tests of Extracted-Iron Distribution by Ground Cover Class

\begin{tabular}{|c|c|}
\hline Classes & Extracted Iron $\left(p_{c a l c}\right)$ \\
\hline Aspen vs. Spruce & 0.15 \\
\hline Spruce vs. Grass & $0.01^{\circ}$ \\
\hline Felsenmeer vs. Aspen & 0.42 \\
\hline Tundra vs. Aspen & 0.15 \\
\hline Willow vs. Aspen & 0.79 \\
\hline Tundra vs. Willow & 0.06 \\
\hline
\end{tabular}


The possibility was considered that the difference between these two groups of sites might be attributable to differences in soil $\mathrm{pH}$ arising from differences in leaf/needle litter. However, the data that had been collected was inadequate to permit a proper investigation, and it was noted that a similar difference did not occur between the aspen and spruce sites. This, plus the fact that none of the differences between extracted-iron levels for the other cover classes is statistically significant, suggests that ground cover is not a significant determinant of "free" iron level.

\subsection{CONCLUSIONS}

Although consistent with the chronosequence hypothesis, the higher extracted-iron levels of Pre-Nisling samples may be attributable either in whole or in part to a topographical factor. Numerous field observations of the study area during the summer months revealed that during summer storms, up to eight centimeters of snow can be deposited on the Pre-Nisling surfaces which can take three or four days to melt. The Pre-Nisling zone also contains the majority of study area sites in which large winter snowbanks can, in some years, remain throughout the summer and provide a continuous supply of melt water to the surrounding regolith.

Greater water supply would tend to favor the production of hematite/goethite while, at the same time, the associated lower ground temperatures would have an inhibiting effect. The net effect of these opposing factors could not be determined precisely with the limited resources available for this study, but there is indirect evidence arising out of a consideration of topographic factors which suggests that the effect of neither temperature nor soil 
moisture conditions can explain the higher extracted-iron levels found in the PreNisling ground surface zone.

This is based in part on a discovery of a negative correlation between extracted iron levels and elevation for mid-slope sites, i.e., sites on Nisling Ruby and St. Elias surfaces. The one thing that these sites should have in common is that they would all be subject to a vertical summer temperature gradient in which surface temperatures should decline at higher elevations. This indicates that the effect of the vertical temperature gradient is to depress rather than to promote iron oxide formation at higher elevations. Therefore, lower summer temperatures per se in the Pre-Nisling zone are unlikely to have been the cause of the higher extracted-iron levels at these sites.

At the same time no significant correlation was found between extractediron levels and the two topographical factors which should control soil-moisture content, i.e., slope angle and slope aspect. This lack of correlations indicates that the higher extracted-iron levels found at the Pre-Nisling sites are unlikely to have been caused by higher soil moisture content created by summer snow accumulation. Since the higher iron levels cannot be explained by either temperature or soil moisture conditions, one cannot exclude the possibility that the higher indicated iron oxide levels at these sites are a result of greater age.

The only other topographical factor that was considered to be a potential predictor of iron oxide formation was ground cover class. However, examination of the correlations between extracted-iron levels and ground cover indicated that ground cover class is not a reliable indicator.

The fact that the Post-glacial deposits have lower extracted-iron levels than the fine-fraction materials on the Ruby and St. Elias slopes above them is consistent with the additional materials hypothesis. Relative mineral abundance studies of the Post-glacial deposits indicate relatively low levels of iron-rich chlorite which would result in lower iron oxide formation potential. 


\section{SUMMARY AND CONCLUSIONS}

\subsection{GenERAL}

Aerial photography suggests that ground surfaces in the northwest Ruby Range may have been scoured by a least three glacial advances. Earlier studies of the glacial history of the region have relied heavily on visual evidence and reconnaissance mapping. The literature arising out of these studies, which is reviewed in Chapter Two, leaves several unresolved questions concerning whether or not these advances were all stades of one glaciation contemporaneous with the Wisconsinan (Last Glaciation) as postulated in Hughes et al. (1969); or, alternatively, whether one or more of these advances were events from earlier glaciations, the possibility of which is raised by the geological history of the region.

The purpose of this study was to examine weathering patterns in the regolithic fine-fraction $(\phi<2 \mathrm{~mm})$ of the northwest Ruby Range to determine if a chronosequence exists which could help to resolve questions concerning the glacial chronology of this portion of the Yukon Plateau. The multiple working hypotheses approach was adopted, and, to this end, three working hypotheses the "chronosequence hypothesis", the "toposequence hypothesis", and the "additional materials hypothesis" were formulated as the basis for the analysis of the weathering patterns. These hypotheses are not considered to be mutually exclusive of one another.

The chronosequence hypothesis postulated that weathering patterns in the fine-fraction materials in the study area regolith would form a discernible chronosequence reflecting the glacial history of the bedrock surfaces on which 
they currently rest. With this hypothesis, it was assumed that the most advanced weathering would be found in the fine-fraction materials covering the oldest surfaces. It was anticipated that the degree of weathering of the fine-fraction materials would indicate, if not in the absolute sense, at least in the relative sense, the age of the surfaces of the underlying bedrock. In this way, the finefraction weathering patterns would help to resolve current uncertainties concerning the glacial chronology of the region.

The toposequence hypothesis postulated that even if a chronosequence does exist in the fine-fraction material, the characteristics of that chronosequence would be masked, in whole or in part, by topographically induced weathering patterns. It was anticipated that the most likely topographic factors to produce strong weathering patterns would be elevation, slope angle, slope aspect, and vegetation cover.

The additional materials hypothesis postulated that even if a chronosequence and/or toposequence does exist, the weathering characteristics of either sequence could be masked in whole or in part by additional fine-fraction materials. From the literature reviewed and from observations in the field, it was anticipated that the bulk of these additions would be in form of loess, volcanic ash, and glacial deposits.

\subsection{CHRONOSEQUENCE HYPOTHESIS}

The chronosequence hypothesis was based, in part, on observations during the initial reconnaissance of advanced-weathering features (tors, weathering pits, abnormally thick rinds, and the presence of grus) at Pre-Nisling sites in Lithological Zone 2 (see Chapter Three). However, subsequent field investigation led to the discovery of advanced-weathering characteristics on a site at an elevation below the Pre-Nisling lower limit. In addition, it was noted 
that these weathering characteristics were only found at sites where the felsic bedrock contained an abundance of biotite.

$X$-ray diffraction analysis of the degrees of weathering of muscovite and biotite revealed that biotite is considerably more prone to vermiculization than muscovite under the prevailing periglacial conditions. Since, a mica will undergo a volumetric increase of up to $40 \%$ during vermiculization, it follows that the relatively unstable biotite could cause advanced-weathering characteristics to develop in a relatively short period of time in a bedrock outcropping which contained an abundance of biotite. This suggests that the advanced-weathering characteristics observed on some Pre-Nisling surfaces are more a consequence of mineral composition than of great age.

In addition, field observation of the thinness of weathering rinds on granitic erratics in Lithological Zone 1 (see Chapter Three) suggest relatively recent (Wisconsinan) deposition according to criteria put forward by Birkeland (1984). This raises the possibility that all three glacial events in the study area could have occurred within the timespan of the Wisconsinan. However, there are difficulties in applying Birkeland's (1984) data to the weathering environment of the northwest Ruby Range, and, for this reason, the evidence of thin weathering rinds is inconclusive.

The laboratory investigation of phyllosilicate alteration (see Chapter Four) clearly indicates that chemical weathering does take place in the northwest Ruby Range. However this form of weathering appears to be confined to the production of secondary vermiculite and to chlorite- and vermiculite-based mixed-layer phyllosilicates of randomly interstratified composition. This, according to the literature consulted, is indicative of a very early stage of weathering.

The chronosequence model suggests if ground surface age alone determined the frequency of phyllosilicate alteration occurrences, the Pre-Nisling Zone sites should exhibit the highest proportion of occurrences and the Postglacial Zone should exhibit the lowest. Of all the muscovite-schist sites 
investigated, 59\% exhibited some degree of phyllosilicate alteration. In the PreNisling Zone, $95 \%$ of the sites exhibited a degree of alteration indicating an above-average frequency of alteration occurrences consistent with the chronosequence model. However, $75 \%$ of all St. Elias sites contained alteration occurrences - a considerably higher proportion than those of the older Nisling $(30 \%)$ and Ruby $(22 \%)$ surfaces. From this, it was concluded that the chronosequence model fails to explain the observed distribution of phyllosilicate alteration occurrences.

In addition to investigating occurrences of vermiculization and interstratification, X-ray diffraction records were examined for evidence of the presence of other phyllosilicate weathering products, i.e., smectite, gibbsite, and kaolinite. In the 5 fine-fraction samples tested for smectite, only two gave positive indications. However, in both cases, this took the form of very small diffraction peaks in the 18-19 $\AA$ range following ethylene glycol solvation. In fact, these peaks were so small that they could have been simply random "background noise", and, hence, their appearance does not constitute convincing proof that smectites are being produced at those sites. The laboratory work produced no indication of the presence of the advancedweathering products, gibbsite and kaolinite, even in a clay-rich sample. However, due to limitations imposed by small sample size on the extraction of adequate amounts of the clay-size fraction, the possibility that trace amounts of these advanced secondary weathering products may have formed cannot be completely dismissed.

The chronosequence model developed for this study predicts fine-fraction depletion rates for chlorite/vermiculite and muscovite should be highest in the oldest (Pre-Nisling) ground surface zone, and sequentially lower in each chronologically successive zone. The analysis of the samples, however, indicated that there is little difference between indicated depletion rates on PreNisling, Nisling, and Ruby surfaces. The only significant differences found were between the indicated depletion rates of this group of surfaces and the younger 
St. Elias and Post-glacial surfaces, and in both these cases, the younger surfaces actually had higher indicated depletion rates.

For the five ground surface zones, the total range of indicated depletion rates for chlorite/vermiculite ( 8 to $61 \%$ ) was found to be slightly higher than the range of indicated depletion rates for muscovite (2 to $59 \%$ ). The higher indicated depletion rates for chlorite/vermiculite relative to the rates for muscovite were as expected in view of the known weathering stability characteristics of the minerals involved. In fact, when the 102 muscovite-bearing schist sites were grouped together regardless of transect and arranged according to elevation, it was found that there was a strong negative correlation between indicated fine-fraction phyllosilicate depletion and elevation. This is clearly inconsistent with the chronosequence model.

The evidence from the dithionite-citrate-extracted iron levels is mixed with respect to the chronosequence hypothesis. The mean dithionite-extracted iron level of the Pre-Nisling samples is significantly higher than that of the Nisling samples. Unfortunately, although this indicates that the Pre-Nisling surfaces are probably somewhat older than the other surfaces within the study area, it does not help in dating the Nisling, Ruby, and St. Elias glacial events.

In summary, none of the evidence produced during this study supports the original hypothesis that a multi-stage chronosequence would be revealed which could assist in dating the Nisling. Ruby and St. Elias glacial events. In fact, none of the evidence produced in this study is inconsistent with the view put forward in Hughes et al. (1969) that all three of these glacial events may have been contemporaneous with the Wisconsinan.

\subsection{TOPOSEQUENCE HYPOTHESIS}

In the search for reasons why the expected chronosequence was not detected, the relationship of the frequency of phyllosilicate alteration 
occurrences to the topofactors, site aspect and slope angle, was investigated. This pair of topofactors were selected because each could influence soilmoisture conditions, and higher soil-moisture content would promote the hydration of mica, a process which is central to vermiculization. It was found that vermiculization had occurred at 60 of the 102 sites at which the assumed parent material is muscovite-schist. It occurred in $88 \%$ of sites whose aspect favored high moisture content (north, northeast, and east), but it occurred in only $53 \%$ of sites whose aspect favored lower moisture content (south, southwest, and west). This difference between the two groups of sites was found to be statistically significant at the .05 level. At the same time the investigation of the relationship between alteration frequency and slope angle produced inconclusive results. Although the group of sites in which the alterations occurred had a lower mean slope angle $\left(12.42^{\circ}\right)$ than the group in which no alteration was detected $\left(16.65^{\circ}\right)$, a Student's $t$-test of the difference narrowly failed to meet the .05 significance criterion with a calculated $p$ value of .057 .

The same pair of topofactors were also examined to determine if they had any influence on fine-fraction relative mineral abundance. In an attempt to control for elevation, 20 sites where the assumed parent material is muscoviteschist were selected from within as narrow an elevation bandwidth as possible $(2170-2100 \mathrm{~m})$. The moderate degree of negative correlation between slope angle and chlorite/vermiculite abundance, as represented by the $7 \AA$ peak, was found indicating local chlorite/vermiculite accumulation at sites with lower slope angles. However, with a calculated $p$-value of 0.6 , this correlation is not convincing.

The case for the influence of slope aspect on chlorite/vermiculite depletion is even less convincing. As was done in the study of the influence of slope aspect on phyllosilicate alteration frequency in Chapter Four, sites were divided into two classes based on whether or not the site aspect would favor high or low soil-moisture content. In order to keep variability arising out of elevation and slope angle factors to a minimum, while at the same time ensuring 
an adequate degree of variability in slope aspect, sampling was restricted to sites within an elevation band of 2100 to $1800 \mathrm{~m}$ and to sites within that band whose slope angle was less than $11^{\circ}$. The mean fine-fraction $7 \AA$ peak intensity ratio was found to be 1.59 for "low moisture" sites and 1.85 for "high moisture" sites. A Student's $t$-test on this apparent difference produced a $t$-value of -1.12 . The calculated $p$-value based on 12 degrees of freedom indicates that the difference is not significant at the 0.14 level.

Pedogenic iron oxide distribution as estimated from the dithionite-citrate extractions was examined to determine if any specific topofactors had produced statistically significant effects on pedogenic iron oxide formation in the Lithological Zone 1. When all Zone 1 transects were included, it was found that there was a positive correlation $(r=0.59)$ between extracted iron and elevation. However, when the Pre-Nisling and Post-glacial sites were excluded, the correlation with the remaining sites was weakly negative indicating that elevation per se is not a reliable predictor of pedogenic iron oxide formation. In addition, a Pearson's product moment correlation calculation $(r=0.05)$ indicated that there was no significant correlation between extracted-iron levels and slope angle.

An attempt was also made by means of Student's $t$-tests to determine if ground-cover could be used as a predictor of pedogenic iron oxide formation. Differences significant at the 0.05 rejection level were found only in the case of sites where the predominant ground-cover was spruce versus sites where the predominant cover was floodplain grass. The possibility was considered that the difference between these two groups of sites might be attributable to differences in soil $\mathrm{pH}$ arising from differences in leaf/needle litter. However, the data that had been collected was inadequate to permit a proper investigation, and it was noted that a similar difference did not occur between the aspen- and sprucecovered sites. This, plus the fact that none of the differences between extractediron levels for the other cover classes are statistically significant, suggests that ground cover per se has not been a significant determinant of pedogenic iron oxide formation within the study area.. 
This examination of topofactor influence on observed fine-fraction weathering patterns revealed statistically significant differences in only two instances: in phyllosilicate alteration frequency based on slope aspect, and in differences in extracted iron levels between spruce-covered and floodplain grass-covered sites. At first glance, this would suggest that the topofactors have had a very limited effect on the observed fine-fraction weathering patterns. However, the sampling plan for this study was devised primarily to establish the presence of a chronosequence. As a consequence of this, the sampling has provided insufficient data to fully explore all the complex interrelationships between the various combinations of the topographically-related factors which could influence the study area's fine-fraction weathering patterns. Topofactors could well have had a greater influence on the weathering patterns than the results of this study indicate.

\subsection{AdDITIONAL MATERIALS HYPOTHESIS}

Detectable amounts of loess identified through the characteristic $3.03 \AA$ calcite peak were found in the fine-fraction samples at 3 out of 6 sites below $970 \mathrm{~m}$ elevation in the Cultus Creek valley, and further west at 2 out of 5 sites in the Jarvis River valley below $1040 \mathrm{~m}$ elevation. The most probable source of the loess in the Cultus Creek valley is from sediments deposited by the Kaskawulsh Glacier in the Slim's River Valley. This source lies approximately $20 \mathrm{~km}$ upwind from the Cultus Creek sites. Possible sources of loess in the Jarvis River valley sites are sediments deposited by the St. Elias lobe which advanced up the valley and into the study area from the southeast, or alternatively from a second St. Elias lobe which advanced from the south into Cultus Bay in Kluane Lake.

Within the study area there is no evidence to indicate loess deposition on any sites above $1040 \mathrm{~m}$ elevation. Below that elevation, however, the fact that the $3.03 \AA$ peaks recorded from the 5 loess-contaminated sites are relatively 
strong suggests that the loess addition to the original fine-fraction material here is appreciable. A comparison of the fine-fraction mean peak intensity ratios of the four loess-free Post-glacial Ground Surface Zone sites to an unadulterated Neoglacial loess sample from the Slim's River valley suggests that, although the effect would be minimal on the $7 \AA$ peaks, the addition of loess would tend to depress the $5,4.26$, and $3.19 \AA$ peaks while simultaneously tending to enhance the $8.4 \AA$ peak. The enhancement of the $8.4 \AA$ peak would tend to inflate estimates of volcanic ash content within the Post-glacial Zone. However, because all these effects are limited to the Post-glacial Zone, it cannot be said that the deposition of loess was a major contributor to the failure to detect a useable fine-fraction chronosequence within the study area as a whole.

From very low relative abundance levels at the highest elevations, the volcanic ash content increases to reach peak abundance at approximately $1650 \mathrm{~m}$ elevation. From $1600 \mathrm{~m}$ elevation downwards, however, the ash component of the fine-fraction materials remains fairly constant at a slightly lower relative abundance level. One possible explanation for this distribution pattern is that there was probably fairly rapid early transportation of the ash down-slope until its progress was retarded by vegetation, and it subsequently became incorporated into the existing fine fraction. A second possible explanation is that the distribution pattern was dictated simply by the aeolian transport capability during deposition. Due to relatively wide distribution throughout the study area, volcanic ash was potentially a major source of finefraction contamination. However, its effect is still limited because it contains only one mineral ingredient - feldspar - which is also a principal component in Zone 1 bedrock and the fines which developed from it. Therefore the main effect of the presence of volcanic ash on the outcome of this study was simply that it precluded the use of feldspar as a weathering indicator.

The regolith itself, as reported in Chapter Three, is a likely major source of additional fine-fraction material. Field investigation revealed that, in almost all instances, the fine-fraction is fully integrated into the regolithic structure. 
Between the fine-fraction and the larger-sized fraction of the regolith, a sizecontinuum exists that includes chips in the 2 to $5 \mathrm{~mm}$ range which appear to be fresh spalling detritus from the surrounding clasts. These chips, in turn, are, in all likelihood, contributing fresh material to the existing fine-fraction. Although this contribution could not be quantified with the resources available to this study, the sheer abundance of coarse-fraction materials within the regolith creates a potential for fresh material to seriously obscure weathering features in older fines. In the periglacial environment of the Ruby Range, congelifraction is the most likely process to have produced this new material, and the processes by which it could adulterate the older fine-fraction materials would be a combination of congeliturbation and the activities of burrowing mammals (ground squirrels, marmots, and pika).

Another important source of additional fine-fraction material lies in the terrace-like features. The precise nature of these features cannot be accurately identified without further detailed field investigation, but it can be safely assumed that, at some point the sandy material of which they are largely composed, has been subjected to sorting in meltwater streams. As a consequence, such materials could be expected to be quartz-rich and phyllosilicate-poor. This could readily explain the statistically verified tendency for phyllosilicates to decline in relative abundance at lower elevations and for the quartz component to rise.

The presence of these quartz-rich materials could also explain the chronosequence anomaly in which the younger St. Elias has significantly higher relative quartz abundance (and a lower phyllosilicate component) than the supposedly older Ruby surfaces. In this case, the younger St. Elias surfaces would have suffered less erosion of the quartz-rich sands of glacial origin. The effect would be to produce a fine-fraction relative mineral abundance pattern in the St. Elias zone which would falsely indicate a greater age for these surfaces.

The presence of quartz-rich deposits at lower elevations could also explain a rather puzzling tendency for the Post-glacial surfaces to have significantly lower extracted-iron levels than surfaces, which should not be much 
older, situated immediately above them. The sand-rich terraces of the Postglacial zone are much more extensive than the remnants found on higher ground surface zones. As a consequence of this, the Post-glacial deposits should have more depleted iron-chlorite levels, and at sites in which the assumed parent material is muscovite-schist, iron-chlorite is a major source of pedogenic iron.

For the purposes of this study, the upper limit of the Post-glacial Ground Surface Zone was set at $1098 \mathrm{~m}$ elevation. This was based on field observations of the elevation of the upper surfaces of the extensive terraces in the Cultus Creek and Jarvis River valleys. However, the relative mineral abundance study reveals that a distinct break in the slope of the abundance trend for quartz occurs at $1300 \mathrm{~m}$ elevation. In retrospect, the $1300 \mathrm{~m}$ contour may serve as a more useful boundary. Extending the boundary upwards by this amount does not appear to alter the mean relative mineral abundance levels for the remaining sites of either the Ruby or St. Elias ground surface zones.

\subsection{CONTRIBUTIONS}

The purpose of this study was to examine weathering patterns in the regolithic fine-fraction of the northwest Ruby Range to determine if a chronosequence exists which can help to resolve questions concerning the glacial chronology of this portion of the Yukon Plateau. A chronosequence which could be used to date the glacial events described by Muller (1967) was not identified. However, this study did produced other evidence, none of which is inconsistent with the hypothesis put forward by Hughes et al. (1969) that all three glacial events, described by Muller (1967) as having left evidence of occupation within the study area, were probably all stades of a single Cordilleran glacial which was approximately contemporaneous with the continental Wisconsinan. The moraines and tills suggesting distinct events, could well be the result of local recessions and still-stands or local advances during regional deglaciation. 
Furthermore, advanced-weathering features observed during the initial reconnaissance such as tors, weathering pits, thick weathering rinds, and grus were found to be restricted to higher elevation sites where there was an abundance of biotite in felsic bedrock. Laboratory testing established that, under the prevailing periglacial conditions, biotite is very susceptible to swelling through hydration, which provides a mechanism for unusually rapid weathering of felsic rock, and, hence, the advanced-weathering features observed at these sites gave a misleading impression of very long exposure to subaerial weathering.

This study was also able to identify, through marker minerals, patterns of distribution of aeolian- and glacially- transported additions to the regolithic finefraction. Although previous work had identified the presence of loess and volcanic ash, its distribution with respect to both elevation and range has never previously been previously determined for this part of the Ruby Range. In addition, the presence of widespread amounts of quartz-rich sandy glacial meltwater deposits at elevations above the Post-glacial zone has never been previously reported.

In the course of this investigation, some major limitations on the investigative methods used in this study were identified. One of the most important of these is that older regolithic fine-fraction materials can be adulterated by the addition of freshly weathered material through the processes of congelifraction and congeliturbation as well as the activities of burrowing mammals. A second constraint encountered is that the absence of sufficient material in the clay-size range makes it impossible to identify trace amounts of secondary clay minerals such as kaolinite and gibbsite whose presence could be useful establishing the age of the host deposit. A third major constraint is that relative mineral abundance can only be determined if the mineral composition of the bedrock parent material is sufficiently homogeneous to permit a meaningful comparison of fine-fraction samples to that of the bedrock parent material. Failure to meet this requirement for this study meant that relative mineral 
abundance could not be determined throughout approximately half of the study area.

In terms of basic methodology, a review of the literature indicated that a study of the distribution of regolithic fine-fraction weathering characteristics in a periglacial environment had never been previously attempted on a scale large enough to permit statistical validation of observed trends. When the data indicated that the commonly employed method of quartz normalization would prove inadequate, a new method based on a 12-peak average normalization standard was developed. This new method proved to be especially useful in differentiating between apparent and real quartz enrichment - a step crucial to a major finding in this study. This method of normalization should prove useful in future studies in which the excessive variability of the quartz component is suspected.

In summary, this study has produced mixed results. Its single greatest shortcoming was the inability to detect a useable chronosequence by these methods. With respect to use of this approach in future studies, the difficulties created by congelifraction and congeliturbation impose major limitations on the application of this approach to problems of glacial chronology. On the positive side, however, this study demonstrates the potential of this approach for determining the composition and distribution of fine-fraction additions of various provenances. 


\section{REFERENCES}

Barnhisel, R.I., 1977. Chlorites and hydroxy interlayered vermiculite and smectite. In J.B. Dixon and S.B. Weed (eds.), Minerals in soil environments, Soil Sci. Soc. Am. Monogr., Soil Sci. Soc. Am, Madison, pp. 331-356.

Barshad, I., 1948. Vermiculite and its relation to biotite as revealed by base exchange reactions, $\mathrm{X}$-ray analysis, differential thermal curves and water content, Am. Miner. 33, pp.665-678.

Bell, R., 1884. Observations on geology, minerology and botany of the Labrador coast, Hudson's Strait and Bay, G.S.C., Report of Progress, 1882-83-84, Part DD.

Berry, R.W., 1987. Mineralogical and Particle Size Analyses of Leda Clay Samples: Analytical Techniques, Carleton University Geotechnical Science Laboratories, Ottawa, 28p.

Biermans, V. and Baert, L., 1977. Selective extraction of amorphous Al, $\mathrm{Fe}$ and Si oxides using an alkaline Tiron solution. Clay Miner., 12, pp. 127-135.

Birkeland, P.W., 1984. Soils and Geomorphology. Oxford University Press, New York, 372p.

Birkeland, P.W., and Janda, R.J., 1971: Clay mineralogy of soils developed from Quaternary deposits of the eastern Sierra Nevada, California, Bull. of the Geol. Soc. of Amer., 82, pp. 2495-2512.

Bloom, A.L., 1978: Geomorphology. Prentice-Hall, Englewood Cliffs, 497p.

Bockheim, J.G. 1979. Relative age and origin of soils in eastern Wright Valley, Antarctica, Soil Sci., 128 No. 3, pp.142-152.

Bockheim, J.G. 1980. Properties and classification of some desert soils in coarse-textured glacial drift in the Arctic and Antarctic, Geoderma. 24, 4569.

Borggaard, O.K., 1988. Phase identification by selective dissolution techniques. In J.W. Stucki, B.A. Goodman and U. Schwertmann (eds.), Iron in Soils and Clay Minerals, D. Reidel Publishing Co., Bad Windsheim, pp.83-94. 
Borns, H. W. Jr. and Goldthwait, R. P., 1966. Late-Pleistocene fluctuations of Kaskawulsh Glacier; Am. Jour. of Sci., 269, pp.600-619. *Reprinted in 1969, in V.C. Bushnell and R.G. Ragle (eds.), Icefield Ranges Research Project Scientific Results, Am Geog. Soc. and Arctic Inst. of N. Am., 1, pp.187-196.

Bostock, H.S., 1948. Physiography of the Canadian Cordillera, with special reference to the area north of the fifty-fifth parallel, Geol. Surv. Can. Mem. 307.

Bostock, H.S., 1952. Geology of the northwest Shakwak Valley, Yukon Territory, Geol. Surv. Can. Mem. 267.

Bostock, H.S., 1966. Notes on glaciation in central Yukon Territory. G.S.C. Paper 65-36, Geological Survey of Canada,18p.

Bostock, H.S., 1969. Kluane Lake, Yukon Territory: its drainage and allied problems. In V.C. Bushnell and R.H.Ragle (eds.), Icefield Ranges Research Project: Scientific Results, 1, Arctic Institute of North America, Montreal, (4 Vols), pp.149-160.

Boulton, G.S., 1982. A glacio-isostatic facies model for late Quaternary events in Spitsbergen and the Arctic. Nature, 298, pp.437-441.

Brewster, G.R., 1980. Effects of chemical pretreatment on X-ray powder diffraction characteristics of clay minerals derived from volcanic ash, Clays Clay Miner. 28, 303-310

Brindley, G.W., 1980. Order and disorder in clay mineral structures. In G.W. Brindley and G. Brown (eds.), Crystal Structures of Clay Minerals and Their X-ray Identification, Mineralogical Society, London, pp.125-195.

Brindley, G.W., 1980a. Quantitative X-ray mineral analysis of clays. In G.W. Brindley and G. Brown (eds.), Crystal Structures of Clay Minerals and Their X-ray Identification, Mineralogical Society, London, pp.411-438.

Brown, G. and Brindley, G.W., 1980. X-ray diffraction procedures for clay mineral identification. In G.W. Brindley and G. Brown (eds.), Crystal Structures of Clay Minerals and Their X-ray Identification, Mineralogical Society, London. pp.305-360. 
Bryan, M.L., 1974. Sedimentation in Kluane Lake. In V.C. Bushnell, and M.G. Marcus (eds.), Icefield Ranges Research Project Scientific Results, 4, Arctic Institute of North America, Montreal, pp.151-154.

Burn, C.R., 1994. Permafrost, tectonics, and past and future regional climate change, Yukon and adjacent Northwest Territories, Can. J. Earth Sci., 31, pp. 182-191.

Capps, S.R.,1915. An ancient volcanic eruption in the Upper Yukon Basin, U.S. Geol. Surv Prof. Paper 95, pp.59-64.

Carroll, D., 1970. Clay minerals: a guide to their X-ray identification, Geological Society of America, Special Paper 126, 80p.

Chalmers, R., 1896. Report on the surface geology of eastern New Brunswick, northeastern Nova Scotia and a portion of Prince Edward Island, Geol.Surv.Can. Annual Report, 7.

Chamberlin, T.C., 1890. The method of multiple working hypotheses, Science (old series), 15, 92. Reprinted in Science, 148, pp. 754-759.

Chao, T.T., 1984. Use of partial dissolution techniques in geochemical exploration. J. Geochem. Explor., 20, pp. 101-135.

Chao T.T., and Theobald, Jr., P.K., 1976. The significance of secondary iron and manganese oxides in geochemical exploration. Econ. Geol., 71, pp.15601569.

Chao, T.T., and Zhou, L., 1983. Extraction techniques for selective disolution of amorphous iron oxides from soils and sediments. Soil Sci. Soc. Am. J., 47 , pp. $225-232$.

Clague, J.J., 1989. Quaternary sea levels (Canadian Cordillera). In R.J. Fulton (ed.), Quaternary Geology of Canada and Greenland, Geol. Surv. Can., Geology of Canada, No.1, Chap. 1, pp. 43-47.

Clague, J.J.; Evans; S.G., Rampton, V.N.; and Woodsworth, G.J., 1995 Improved age estimates for the White River and Bridge River tephras western Canada. Can. J. Earth Sci., 32, pp. 1172-1179.

Coleman, A.P., 1920. Extent and thickness of the Labrador Ice Sheet, Geol. Surv. Am. Bulletin, 31, pp. 319-328. 
Dahl, R., 1966. Blockfields, weathering pits and tor-like forms in the Narvik Mountains, Norland, Norway, Goeogr. Annaler, 48, Ser. A, No.2, pp.5585.

Daly, R.A., 1902. The geology of the northeast coast of Labrador, Harvard University Museum of Comparative Zoology Bulletin, 38, pp.205-270.

Denton, G.H., 1965. Late Pleistocene glacial chronology, Northeastern St. Elias Mountains, Canada, unpublished Ph D. dissertation, Yale University, 88p.

Denton, G.H., 1974: Quaternary glaciations of the White River valley, Alaska, with a regional synthesis for the northern St. Elias Mountains, Alaska and Yukon Territory, Geol. Soc. of Amer. Bull., 85, pp.871-892.

Denton, G.H. and Armstrong, R.L., 1969. Miocene-Pliocene glaciations in southern Alaska, Am. J. Sci., 267, pp. 1121-1142.

Denton, G.H. and Karlén, W. 1973, Holocene climatic variations - their pattern and possible cause, Quaternary Research, 3, pp.155-205.

Denton, G.H. and Stuiver, M., 1966. Neoglacial chronology, northeastern St. Elias Mountains, Canada, Am. Jour. of Sci., 261, pp.577-599.

Denton, G.H. and Stuiver, M., 1967. Late Pleistocene glacial stratigraphy and chronology, northeastern St. Elias Mountains, Yukon Territory, Canada; Geol. Soc. of Amer. Bull., 78, pp. 458-510. Reprinted in 1969: in V.C. Bushnell and R.H. Ragle (eds.), Icefield Ranges Research Project Scientific Results; Am. Geog. Soc. and Arctic Inst. of N. Am., 1, pp.197217.

Dixon, J.C.,1986. Solute movement on hillslopes in the alpine environment of the Colorado Front Range. In A.D. Abrahams (ed.), Hillslope Processes, Allen and Unwin, Boston, pp. 139-159.

Eisbacher, G.L. and Hopkins, S.L., 1977. Mid Cenozoic paleogeomorphology and tectonic setting of the St. Elias Mountains, Yukon Territory, Report of activities, part B. Geological Survey of Canada, Paper 77-1B, pp. 319335.

Environment Canada, 1996. Ontario Climate Center data release, Fax Takata/Howes, Code 7394521, 5 June 1996, 4p. 
Evans, L.J. and Cameron, B.H., 1979. A chronosequence of soils developed from granitic morainal material, Baffin Island, N.W.T., Cdn. J. Soil Sci., 59, pp.203-210.

Eynon, G. and Walker, R.G., 1974. Facies relationships in Pleistocene outwash gravels, southern Ontario: a model for bar growth in braided rivers, Sedimentology, 21, pp. 43-70.

Fieldes, M. and Swindale, L.D., 1954. Chemical weathering of silicates in soil formation, N.Z. J. of Sci. and Tech., 36B, pp. 140-154.

Flint, R.F., 1943. Growth of the North American Ice Sheet during the Wisconsin Age, Geol. Soc. Am. Bul., 54, pp. 352-362.

Foscolos, A.E., Rutter, N.W., and Hughes, O.L., 1976. The Use of Pedological Studies in Interpreting the Quaternary History of Central Yukon Territory: G.S.C. Bulletin 271, Geological Survey of Canada, Ottawa, 48p.

Geiger, R., 1966. The Climate Near the Ground, Harvard University Press, Cambridge, 611p.

Goldich, S.S., 1938, A study in rock weathering, Jour. Geol., 46, pp. 17-58.

Hay, R.L., 1959. Origin and weathering of late Pleistocene ash deposits on St. Vincent, B.W.I. Jour. Geol., 67, pp.65-87.

Howes, J.E., 1991. An Examination of Two Techniques to Determine the Origin of Soil-Sized Particles on Alpine Slopes in the Duke Valley, Southwest Yukon, unpublished M.A. thesis, Carleton University, 89p.

Hughes, O.L., Campbell, R.B., Muller, J.E., and Wheeler, J.O., 1969. Glacial limits and flow patterns, Yukon territiory, south of 65 degrees north latititude, Geological Survey of Canada, Paper 68-34, 9p.

Hughes, O.L., Tarnocia, C., and Schwager, C.E., 1993. Pleistocene stratigraphy, paleopedology, paleoecology of a multiple till sequence exposed on the Little Bear River, Western District of Mackenzie, N.W.T.. Canada, Can. Jour. Earth Sci., 30, pp. 851-866.

Ives, J.D., 1963. Field problems in determining the maximum extent of Pleistocene glaciation along the eastern Canadian seaboard - a 
geographer's point of view, North Atlantic Biota and their History, Pergamon Press, Oxford, pp.337-354.

Ives, J.D., 1966. Blockfields, associated weathering forms on mountain tops and the nunatak hypothesis, Geogr. Annaler, 48, Ser A, No.4, pp.220223.

Ives, J.D. 1978. The maximum extent of the Laurentide ice sheet along the east coast of North America during the last glaciation, Arctic, 31, No.1, pp.2551.

Jackson, L.E., Jr., Barendregt, R., Irving, E., and Ward, B., 1990. Magnetostratigraphy of early to middle Pleistocene basalts and sediments, Fort Selkirk area, Yukon Territory, Current Research, Part E, Geological Survey of Canada, Paper 90-1E, pp. 277-286

Jackson, M.L., 1969. Soil chemical analysis -- advanced course, Dept. of Soils, $U$. of Wisconsin, Madison, 138p.

Jackson, M.L., Lee, S.Y., Ugolini, F.C., and Helmke, P.A., 1977. Age and uranium content of soil micas from Antarctica by the fisssion particle track replica method, Soil Sci., 123, pp. 241-248.

Jackson, M.L. and Sherman, G.D., 1953. Chemical weathering of minerals in soils, Adv. Agron., 5, pp. 219-318.

Jackson, M.L., Tyler, S.A, Willis, A.L., Bourbeau, G.A., and Pennington, R.P., 1948. Weathering sequence of clay -size minerals in soils and sediments, J. Phys. Colloid Chem., 52, pp.1237-1260.

Johnson, P.G. and Kodybka, R.J.,1983. Problems of Quaternary glacial correlation due to regional ice/local ice interactions, Ruby Range, Southwest Yukon. In W.C. Mahaney (ed.), Correlation of Quaternary Chronologies, Geo Books, Norwich, pp.2-15,2-16, 2-17.

Keller, W.D., 1954. Bonding energies of some silicate minerals, Am. Miner., 39, pp.783-793.

Klages, M.G. and Hopper, R.W., 1982. Clay minerals in northern plains coal overburden as measured by x-ray diffraction, Soil Sci. Soc. Am. J., 46, pp. 415-418. 
Kerner, A., 1891. Die Änderung der Bodentemperatur mit der Exposition [The changes in soil temperature with slope aspect]. Sitz-B. Wien. Akad., 100, pp. $704-729$.

Klassen, R.W., 1987. The Tertiary-Pleistocene stratigraphy of the Liard Plain, southeastern Yukon Territory, Geol. Surv. Can., Paper 86-17.

Kodama, H. and Ross G.J., 1991. Tiron dissolution method used to remove and characterize inorganic compounds in soils. Soil Sci. Soc. Am. J., 55, pp.1180-1187.

Koerner, R.M. and Fisher, D.A., 1979. Discontinuous flow, ice texture and dirt content in the basal layers of the Devon Island Ice Cap, Jour. of Glaciology, 23, 209-222.

Kutzbach, J.E., Guetter, P.J., Ruddiman, WF, and Prell, W. L., 1989. Sensitivity of climate to Late Cenozoic uplift in southern Asia and the American West: numerical experiments, J. of Geophys. Resch., B, 94, pp. 18 39318407.

Lauriol, B., Ford, D.C., and Cinq-Mars, J., 1993. Le concretionnement dans les cavernes du nord du Yukon (Canada) et ses relations avec l'histoire du pergelsol. Program with Abstracts, 3rd International Geomorphology Conference, McMaster University, Hamilton.

Lindsay, W.L., 1998. Solubility and redox equilibria of iron compounds in soils. In J.W. Stucki, B.A. Goodman and U. Schwertmann (eds.), Iron in Soils and Clay Minerals, D. Reidel Publishing Co., Bad Windsheim, pp.6-2.

Lull, H.W., 1964. Ecological and silvaculture aspects. In Ven Te Chow (ed.), Handbook of Applied Hydrology, McGraw Hill, New York, 471p.

MacEwan, D.M.C., 1946. The identification and estimation of the montmorillonite group of minerals with special refence to soil clays. J. Soc. Chem. Ind., 65 , pp. 298-305.

MacEwan, D.M.C. and Wilson, M.J., 1980. Interlayer and intercalation complexes of clay minerals. In G.W. Brindley, and G. Brown (eds.) Crystal Structures of Clay Minerals and Their X-ray Identification. Mineralogical Society, London, pp.197-248. 
Madole, R.F., 1982. Possible origins of till-like deposits near the summits of the Front Range in north-central Colorado; U.S. Geolological Professional Paper 1243, 31p.

Marcus, M. G. and Ragle, R. H.,1972. Snow accumulation in the Icefield Ranges, St. Elias Mountains. In V.C. Bushnell and R.H. Ragle (eds.), Icefield Ranges Research Project: Scientific Results. 3, Arctic Institute of North America, Montreal, (4 Vols), pp. 131-142.

Marshall, C.E., 1977. The Physical Chemistry and Mineralogy of Soils. Vol. II: Soils in Place, John Wiley and Sons, New York, 313p.

Mathieson, A.M. and Walker, G.F.,1954. Crystal structure of Mg-vermiculite; Am. Miner., 39, pp. 231-255.

Matthes, F.E.,1939. Report of Committee on Glaciers; Am. Geophys. Union Trans., 20, pp. 518-523.

Mathews, W.H.1989. Development of Cordilleran landscapes during the Quaternary. In R.J Fulton (ed.), Chapter 1 of Quaternary Geology of Canada and Greenland Geological Survey of Canada, no.1 (also Geol. Soc. Am. , The Geology of North America, K-1.

Mathews, J.V., Jr., and Ovenden, L.E.,1990. Late Tertiary plant macrofossils from localities in arctic/subarctic North America: a review of the data. Arctic, 43, pp.364-392.

Mathews, J. V., Jr., Schweger, C.E., and Hughes, O.L., 1990. Plant and insect fossils from the Mayo Indian Village Section (central Yukon): new data on middle Wisconsinan environments and glaciation. Géographie physique et Quaternaire, 44, pp. 15-26.

McGowen, J.H. and Garner, L.E., 1970. Physiographic features and stratification types of coarse-grained bars - modern and ancient examples. Sedimentology, 14, pp.77-111.

McKeague, J.A.; and Day, J.H., 1966. Dithionite- and oxalate-extractable Fe and $\mathrm{Al}$ as aids in differentiating various classes of soils. Can. J. Soil Sci. 46, 3-22. 
McKeague, J.A., Grant, D.R., Kodama, H., Beke, G.J., and Wang, C., 1983. Properties and genesis of a soil and the underlying gibbsite-bearing sapriolite, Cape Breton Island, Canada. Can. J. Earth Sci., 20, pp. 37-48.

Molnar, P. and England P., 1990. Late Cenozoic uplift of mountain ranges and global climate change: chicken or egg?; Nature, 346, pp.29-34.

Mortensen, J.K. and Erdmer, P., 1992. U-Pb, ${ }^{40} \mathrm{Ar}-{ }^{39} \mathrm{Ar}$, and $\mathrm{K}-\mathrm{Ar}$ ages of the Kluane and Aishihik assemblages in southwestern Yukon Territory. Radiogenic Age and Isotopic Studies, Report 6; G.S.C. Paper 92-2, pp.135-140.

Muller, J.E., 1967. Kluane Lake map-area, Yukon Territory: Geol. Surv. of Can. Memoir 340, 137p.

Nagelschmit, G., 1937. X-ray investigations on clays. Part III. The differentiation of micas by x-ray powder photographs. Z. Kristallogr., Kristallgeom. 97, pp.514-521.

Odell, N.E., 1933. The mountains of northern Labrador. Geogr. J. 82, Ser. 3-4, pp. 193-211, 315-326.

Odell, N.E., 1938. The great ice age. In Forbes, A. (ed.) Northeastern Labrador Mapped from the Air, Special Publication No. 22, Am. Geogr. Soc., New York, pp. 204-215.

Parrish, Randall, R., 1981. Uplift rates of Mt. Logan, Y.T. and British Columbia's central Coast Mountains using fission track dating methods; EOS, 62, p. 60.

Pena, F.; and Torrent, J., 1984. Relationships between phosphate sorption and iron oxides in Alfisols from a river terrace sequence of Mediterranean Spain. Geoderma, 33, pp. 283-296.

Plafker, G. and Addicott, W.O., 1976. Glaciomarine deposits of Miocene through Holocene age in the Yakataga Formation along the Gulf of Alaska margin, Alaska. In T.P Miller (ed.), Recent and Ancient Sedimentary Environments in Alaska. Alaska Geological Society, Anchorage, pp. Q1-Q23.

Protz, R., Ross, C.J., Martini, I. P., and Terasmae, J., 1984. Rate of podzolic soil formation near Hudson Bay, Ontario. Can. J. Soil Sci., 64, pp.31-49. 
Protz, R., Ross, G.J., and Shipitalo, M.J., 1985. The influence of texture on clay weathering and soil formation in mid-northern Ontario. Applied Clay Sci. , 7, pp. 43-55.

Rampton, V.N.,1971. Late Pleistocene glaciations of the Snag-Klutlan area, Yukon Territory; Arctic, 24, pp.277-300.

Rampton, V.N., 1981. Surficial materials and landforms of Kluane National Park, Yukon Territory; Geol. Surv. Can., Paper 79-24, 37p.

Rapp, A., 1960. Recent development of mountain slopes in Kärkevagge and surroundings, northern Scandinavia. Geografische Annaler, 42, pp.65200.

Reynolds, R.C., 1976. The Lorentz factor for basal reflections from micaceous minerals in oriented powder aggregates. Am. Mineral. 61, pp. 484-491.

Reynolds, R.C., 1980. Interstratified Clay Minerals. In G.W. Brindley, and G. Brown, (eds.) Crystal Structures of Clay Minerals and Their X-ray Identification. Mineralogical Society, London, pp.249-303.

Rich, C.I. and Obenshain, S.S., 1955. Chemical and mineral properties of a redyellow podzolic soil derived from sericite schist. Soil Sci. Soc. Am. Proc. 19, pp.334-339.

Ross G.J., 1993. Chemical methods in mineralogical analysis. In M.R. Carter (ed.), Soil Sampling and Methods of Analysis, Lewis Publishers, Boca Raton, pp.745-754.

Ross, G.J., Kodama, H., Wang, C., Gray, J.T., and Lafreniere, L.B., 1983. Halloysite from a strongly weathered soil at Mont Jacques Cartier, Que., Soil Sci. Soc. of Am. J., 47, pp. 327-332.

Ross, G.J. and Wang, C., 1993. Extractable Al, Fe, Mn, and Si. In M.R. Carter (ed.), Soil Sampling and Methods of Analysis. Lewis Publishers, Boca Raton. pp.239-246.

Ross, G.J., Wang, C., and Protz. R., 1984. Soil mineralogical evidence as an indicator of post- and pre-Wisconsinan weathering in Canada. In C. Mahaney (ed.), Correlation of Quaternary Chronologies, Geo Books, Norwich, pp. 191-201. 
Ruddiman, W.F., and Kutzbach, J.E., 1989. Forcing of Late Cenozoic northern hemisphere climate by plateau uplift in southern Asia and the American West. J. of Geophys. Resch.,B, 94, pp. 18409 - 18427.

Ruddiman, W.F., Prell, W.L., and Raymo, M.E., 1988. Northern hemisphere climate regimes during the past $3 \mathrm{Ma}$ : possible tectonic connections. Philosophical Transactions of the Royal Society of London, Series B, 318, pp. 411-430.

Schwertmann, U., 1971. Transformation of hematite to goethite in soils. Nature, 232, pp. $624-625$.

Schwertmann, U., 1988. Occurrence and formation of iron oxides in various pedoenvironments. In J.W. Stucki, B.A. Goodman and U. Schwertmann (eds.), Iron in Soils and Cay Minerals, D. Reidel Publishing Co., Bad Windsheim, 893p.

Schwertmann, U. and Fitzpatrick, R.W., 1992. Iron minerals in surface environments. In H.C.W. Skinner and R.W. Fitzpatrick (eds.), Biomineralization Processes of Iron and Manganese: Modern and Ancient Environments, Catena-Verlag, Cremlingen-Destedt, Catena Supplement 21, pp. 7-30.

Selby, M.J., 1985. Earth's Changing Surface. Oxford University Press, Oxford, $607 p$.

Sharp, R.P., 1960. Pleistocene glaciation in the Trinity Alps of northern California; Am. Journ. Sci., 258, pp. 305-340.

Sheldrick, B.H. (ed.), 1984. Analytical Methods Manual, 1984. Land Res. Inst., Contribution No. 84-30, Agriculture Canada, Ottawa.

Shroba, R.R., 1977. Soil development in Quaternary tills, rock-glacier doposits, and taluses, southern and central Rocky Mountains, Unpublished Ph.D. Thesis, U. of Colorado, Boulder, 424p.

Shroba, Ralph R. and Birkeland, Peter W., 1983. Trends in Late-Quaternary soil development in the Rocky Mountains and Sierra Nevada of the western United States. In S.C. Porter (ed.) Late-Quaternary Environments of the United States. Vol.1. The Late Pleistocene. University of Minnesota Press, Minneapolis. pp. 145-156. 
Stuiver, M., Denton, G.H., and Hughes, T.J., 1979. History of the marine ice sheet in West Antarctica during the last glaciation: a working hypothesis. In G.H. Denton and T.J. Hughes (eds.) The Last great /ce Sheet, WileyInterscience, New York.

Sugden, D.E., 1977. Reconstruction of the morphology, dynamics and thermal characteristics of the Laurentide Ice Sheet at its maximum. Arctic and Alpine Research., 9, No.1, pp. 21-47.

Takata, P., 1996. Kluane Lake, Burwash, and Haines Junction climate data requested from Environment Canada and provided by fax from the Ontario Climate Center, 5 June 1996, 3p.

Talvenheimo, G., and White, J.L., 1952. Quantitative analysis of clay minerals with the X-ray spectrometer. Anal. Chem., 24, pp. 1748-1789.

Tamura, T., 1955. Weathering of mixed-layer clays in soils. Clays Clay Miner., 4, pp. $413-422$.

Tanner, C. 1944. Outlines of the geography, life and customs of NewfoundlandLabrador. Acta Geographica, 8(1), pp.1-906.

Tempelman-Kluit, D., 1980. Evolution of physiography and drainage in southern Yukon. Can. J. Earth Sci.,17, pp. 1189-1203.

Torrent, J.; Guzmann, R.; and Perra, A., 1982. Influence of relative humidity on the crystallization of $\mathrm{Fe}$ (III) oxides from ferrihydrite. Clays Clay Miner, 30, pp. 337-340.

Ugolini, F.C. and Bull, C., 1965. Soll development and glacial events in Antarctica. Quaternia, 7, pp. 251-269.

Ugolini, F.C. and Jackson, D.M., 1977 Weathering and mineral synthesis in Antarctic soils. Third Symp. Antarct.Geol. Geophys. Aug 22-27, 1977. Madison.

Wahl, H.E., Fraser, D.B., Harvey, R.C , and Maxwell, J.B., 1987. Climate of Yukon, Atmospheric Environment Service, Environment Canada, Climatological Studies no. 40. 
Wahrhaftig, Clyde, 1958. Quaternary geology of the Nenana River and adjacent parts of the Alaska Range, Alaska; U.S. Geological Survey Prof. Paper $293 A, 68 p$.

Walker, G.F., 1956. The mechanism of dehydration of Mg-vermiculite. Clays and Clay Miner. 4, pp.101-115.

Walker, G.G., 1961. Vermiculite minerals. In G. Brown (ed.) The X-ray Identification and Crystal Stuctures of Clay Minerals. Mineralogical Society, London, 495p.

Wang, C., and Ross, C.J., 1989. Granitic saprolites: their characteristics, identification and influence on soil properties in the Appalachian region of Canada. Z. Geomorpf. N.F., Suppl.- Bd. 72, pp. 149-161.

Wang, C, Schuppli, P.A., and Ross, C.J, 1987. A comparison of hydroxlamine and ammonium oxalate solutions as extractants for $\mathrm{Al}, \mathrm{Fe}$, and $\mathrm{Si}$ from Spodosols and Spodosol-like soils in Canada. Geoderma, 40, pp.345355.

Wang, C., Stea, R.R., Ross, G.J., and Holstrom, D., 1986. Age estimation of the Shulie Lake and Eatonville tills in Nova Scotia by pedogenic development. Can. J. Earth Sci. 23, pp.115-119.

Ward, B.C., and Jackson, L.E., Jr., 1992. Late Wisconsinan glaciation of the Glenlyon Range, Pelly Mountains, Yukon Territory, Canada. Cdn. J. of Earth Sci., 29, pp. 2007-2012.

Whittig, L.D. and Allardice, W.R., 1986. X-ray diffraction techniques. In A. Klute (ed), Methods of Soil Analysis, Part 1. Physical and Mineralogical Methods - Agronomy Monograph No. 9. American Society of Agronomy Soil Science Society of America, Madison, pp. 331-362.

Willis, A.L., Pennington, R.P., and Jackson, M.L., 1948. Mineral standards for quantitative X-ray diffraction analysis of clay soils. Soil Sci. Soc. Am. Proc., 12, pp. 400-406.

Wolfe, J.A., 1981: A chronologic framework for Cenozoic megafossil floras of northwestern North America and its relation to marine geology. Geol. Soc. of Amer., Special Paper 184, pp. 39-47. 
Wollny, E., 1878. Untersuchungen über den Einfluß der Exposition auf die Erwärmung des Bodens. [Research on the influence of slope aspect on soil warming]. Forsch. a. d. Geb. d. Agrik. Physik, 1, pp.263-294.

Young, A., 1972: Slopes. Oliver and Boyd, Edinburgh, 378p. 


\section{Appendix A : Site Characteristics}

\begin{tabular}{|c|c|c|c|c|c|c|}
\hline Site No. & Elevation (m) & Slope (deg) & Slope Shape & Site Aspect & Drainage & Cover Class \\
\hline \multicolumn{7}{|l|}{ Zone 1 Sites } \\
\hline $1 \mathrm{~A} 1$ & 1874 & 0 & flat & $\mathrm{N}$ & good & upper tundra \\
\hline $1 \mathrm{~A} 2$ & 1836 & 5 & rectilinear & $\mathrm{N}$ & good & upper tundra \\
\hline $1 \mathrm{A3}$ & 1768 & 20 & convex & NE & good & lower tundra \\
\hline $1 \mathrm{~A} 4$ & 1676 & 5 & rectilinear & $N$ & good & lower tundra \\
\hline $1 \mathrm{~A} 5$ & 1524 & 5 & convex & $N$ & fair & lower tundra \\
\hline $1 \mathrm{~A} 6$ & 1432 & 0 & flat & SW & good & upper willow \\
\hline $1 \mathrm{~A} 7$ & 1387 & 25 & convex & SW & good & upper willow \\
\hline $1 \mathrm{~A} 8$ & 1295 & 25 & convex & SW & good & lower tundra \\
\hline $1 \mathrm{~A} 9$ & unrecorded & unrecorded & unrecorded & unrecorded & unrecorded & unrecorded \\
\hline $1 \mathrm{~A} 10$ & 1189 & 24 & convex & SW & good & lower tundra \\
\hline $1 \mathrm{~A} 11$ & 1097 & 29 & convex & SW & good & upper aspen \\
\hline $1 \mathrm{~A} 12$ & 991 & 15 & concave & SW & good & upper aspen \\
\hline $1 \mathrm{~A} 13$ & 914 & 21 & convex & SW & good & lower aspen \\
\hline $1 \mathrm{~A} 14$ & 869 & 0 & flat & SW & good & upper spruce \\
\hline 1B1 & 853 & 0 & flat & W & good & lower aspen \\
\hline 1B2 & 945 & 12 & convex & SW & good & upper aspen \\
\hline $1 \mathrm{B3}$ & 1036 & 22 & convex & SW & good & upper aspen \\
\hline 1B4 & 1128 & 10 & rectilinear & SW & fair & upper spruce \\
\hline 1B5 & 1219 & 26 & convex & SW & good & upper aspen \\
\hline $1 B 6$ & 1311 & 33 & convex & $S$ & good & lower tundra \\
\hline $1 B 7$ & 1402 & 21 & concave & SW & good & upper willow \\
\hline $1 B 8$ & 1493 & 10 & concave & sW & good & upper willow \\
\hline $1 \mathrm{~B} 9$ & 1584 & 14 & concave & SW & good & upper willow \\
\hline $1 \mathrm{~B} 10$ & 1676 & 19 & concave & sW & good & lower tundra \\
\hline $1 \mathrm{~B} 11$ & 1798 & 0 & flat & sW & good & lower tundra \\
\hline $1 \mathrm{~B} 12$ & 1676 & 0 & flat & $S$ & good & lower tundra \\
\hline $1 \mathrm{~B} 13$ & 1890 & 27 & rectilinear & $E$ & good & lower tundra \\
\hline $1 \mathrm{~B} 14$ & 1957 & 10 & rectilinear & SW & good & lower tundra \\
\hline $1 \mathrm{~B} 15$ & 1951 & 0 & flat & NE & fair & felsenmeer \\
\hline $1 \mathrm{C} 1$ & 945 & 2 & concave & $S$ & fair & lower spruce \\
\hline $1 \mathrm{C} 2$ & 1036 & 12 & convex & $S$ & good & lower aspen \\
\hline $1 \mathrm{C} 3$ & 1128 & 28 & concave & $\mathrm{S}$ & good & upper aspen \\
\hline $1 \mathrm{C} 4$ & 1219 & 19 & convex & $E$ & good & upper aspen \\
\hline $1 \mathrm{C5}$ & 1311 & 13 & convex & $E$ & good & upper willow \\
\hline $1 \mathrm{C} 6$ & 1372 & 0 & flat & Flat & good & upper willow \\
\hline $1 C 7$ & 1402 & 13 & unrecorded & SE & good & upper willow \\
\hline $1 \mathrm{C} 8$ & 1493 & 19 & unrecorded & SE & good & upper willow \\
\hline $1 C 9$ & 1585 & 9 & convex & $w$ & good & lower tundra \\
\hline $1 C 10$ & 1676 & 18 & concave & SE & good & lower tundra \\
\hline $1 \mathrm{C} 11$ & 1768 & 18 & concave & SE & good & upper willow \\
\hline $1 \mathrm{C} 12$ & 1859 & 29 & concave & $\mathrm{S}$ & good & lower tundra \\
\hline
\end{tabular}


A-2

\begin{tabular}{|c|c|c|c|c|c|c|}
\hline Site No. & Elevation $(m)$ & Slope (deg) & Slope Shape & Site Aspect & Drainage & Cover Class \\
\hline 1D1 & 1597 & 0 & flat & $\mathrm{N}$ & poor & lower tundra \\
\hline 1D2 & 1661 & 15 & convex & W & good & lower tundra \\
\hline 1D3 & 1737 & 12 & convex & $w$ & fair & lower tundra \\
\hline $1 \mathrm{D} 4$ & 1829 & 21 & convex & W & good & lower tundra \\
\hline 1D5 & 1890 & 18 & convex & W & good & lower tundra \\
\hline $1 \mathrm{D6}$ & 1920 & 0 & flat & Flat & good & upper tundra \\
\hline $1 \mathrm{E} 1$ & 1841 & 24 & concave & SE & good & upper tundra \\
\hline $1 \mathrm{~F} 1$ & 1719 & 0 & flat & $N, S$ & fair & upper tundra \\
\hline $1 F 2$ & 1798 & 25 & rectilinear & $N$ & good & upper tundra \\
\hline $1 \mathrm{~F} 3$ & 1896 & 16 & concave & NW & good & upper tundra \\
\hline $1 \mathrm{G} 1$ & 2149 & 0 & flat & SW & good & felsenmeer \\
\hline $1 \mathrm{G} 2$ & 2131 & 0 & flat & $S$ & good & felsenmeer \\
\hline $1 \mathrm{G} 3$ & 2088 & 0 & flat & $E$ & good & felsenmeer \\
\hline $1 \mathrm{G} 4$ & 2100 & 0 & flat & $E$ & good & felsenmeer \\
\hline $1 \mathrm{G5}$ & 2057 & 0 & flat & NE & good & felsenmeer \\
\hline $1 \mathrm{H} 1$ & 945 & 2 & convex & $S$ & moderate & flood plain \\
\hline $1 \mathrm{H} 2$ & 1036 & 45 & convex & W & good & lower aspen \\
\hline $1 \mathrm{H} 3$ & 1143 & 6 & convex & S & good & lower willow \\
\hline $1 \mathrm{H} 4$ & 1219 & 21 & concave & S & good & lower aspen \\
\hline $1 \mathrm{H} 5$ & 1326 & 28 & convex & S & good & upper aspen \\
\hline $1 \mathrm{H} 6$ & 1402 & 8 & concave & $S$ & good & upper willow \\
\hline $1 \mathrm{H} 7$ & 1469 & 0 & flat & flat & good & upper willow \\
\hline $1 \mathrm{H} 8$ & 1554 & 13 & convex & $S$ & good & lower tundra \\
\hline $1 \mathrm{H} 9$ & 1664 & 7 & convex & SW & good & lower tundra \\
\hline $1 \mathrm{~J} 1$ & 1128 & 8 & rectilinear & $S$ & good & lower spruce \\
\hline $1 \mathrm{~J} 2$ & 1109 & 5 & rectilinear & $\mathrm{S}$ & good & lower spruce \\
\hline $1 \mathrm{~J} 3$ & 1113 & 9 & convex & S & good & lower spruce \\
\hline $1 J 4$ & 1134 & 7 & concave & $S$ & good & lower spruce \\
\hline $1 \mathrm{~K} 1$ & 2195 & 25 & convex & NW & good & felsenmeer \\
\hline $1 \mathrm{~K} 2$ & 2316 & 0 & flat & flat & good & felsenmeer \\
\hline $1 \mathrm{~K} 3$ & 2286 & 12 & convex & SW & good & felsenmeer \\
\hline $1 \mathrm{~K} 4$ & 2286 & 12 & rectilinear & NE & fair & felsenmeer \\
\hline $1 \mathrm{~K} 5$ & 2225 & 10 & convex & $S$ & good & upper tundra \\
\hline $1 \mathrm{~K} 6$ & 2195 & 18 & convex & $S$ & good & upper tundra \\
\hline $1 \mathrm{~K} 7$ & 2103 & 18 & convex & SE & good & upper tundra \\
\hline $1 \mathrm{~K} 8$ & 2134 & 43 & rectilinear & $w$ & good & upper tundra \\
\hline $1 \mathrm{~K} 9$ & 2158 & 25 & convex & $N$ & good & felsenmeer \\
\hline $1 \mathrm{~K} 10$ & 2195 & 34 & concave & $E$ & good & felsenmeer \\
\hline $1 \mathrm{~L} 1$ & 1890 & 7 & convex & W & good & upper tundra \\
\hline $1 \mathrm{~L} 2$ & 1969 & 16 & convex & W & good & upper tundra \\
\hline $1 \mathrm{~L} 3$ & 2094 & 3 & convex & $\mathrm{N}$ & good & upper tundra \\
\hline $1 L 4$ & 2164 & 6 & rectilinear & NE & good & felsenmeer \\
\hline 1L5 & 2240 & 25 & rectilinear & $N$ & good & upper tundra \\
\hline $1 \mathrm{~L} 6$ & 2316 & 0 & flat & $N$ & fair & felsenmeer \\
\hline $1 L 7$ & 2316 & 0 & flat & $E$ & good & felsenmeer \\
\hline $1 L 8$ & 2316 & 5 & rectilinear & W & good & felsenmeer \\
\hline 1L9 & 2316 & 0 & flat & W & good & felsenmeer \\
\hline $1 \mathrm{~L} 10$ & 2347 & 6 & convex & NW & good & upper tundra \\
\hline
\end{tabular}


A-3

\begin{tabular}{|c|c|c|c|c|c|c|}
\hline Site No. & Elevation (m) & Slope (deg) & Slope Shape & Site Aspect & Drainage & Cover Class \\
\hline 1L11 & 2316 & 19 & convex & $W$ & good & upper tundra \\
\hline 1L11A & 2301 & 0 & flat & $E$ & good & felsenmeer \\
\hline 1L12 & 2262 & 23 & convex & S & good & upper tundra \\
\hline $1 \mathrm{~L} 13$ & 2170 & 14 & convex & S & good & felsenmeer \\
\hline $1 \mathrm{M} 1$ & 823 & 19 & concave & $w$ & good & floodplain \\
\hline $1 \mathrm{M} 2$ & 838 & 0 & flat & SW & good & floodplain \\
\hline $1 \mathrm{M} 3$ & 805 & 16 & convex & SW & good & floodplain \\
\hline $1 \mathrm{M} 4$ & 860 & 18 & convex & $S$ & good & floodplain \\
\hline $1 \mathrm{~N} 1$ & 1839 & 0 & flat & flat & good & upper tundra \\
\hline $1 \mathrm{~N} 2$ & 1737 & 17 & concave & $\mathrm{N}$ & good & upper tundra \\
\hline $1 \mathrm{~N} 3$ & 1631 & 14 & rectilinear & $\mathrm{N}$ & good & lower tundra \\
\hline $1 \mathrm{~N} 4$ & 1524 & 19 & convex & NW & moderate & upper willow \\
\hline 1N5 & 1433 & 22 & concave & NW & good & upper willow \\
\hline $1 \mathrm{~N} 6$ & 1341 & 26 & convex & $w$ & good & upper willow \\
\hline $1 \mathrm{~N} 7$ & 1280 & 20 & convex & W & good & upper willow \\
\hline $1 \mathrm{~N} 8$ & 1189 & 0 & flat & flat & good & upper willow \\
\hline 1P1 & 2134 & 31 & rectilinear & SE & good & felsenmeer \\
\hline 1P2 & 2088 & 25 & convex & SE & good & felsenmeer \\
\hline 1P3 & 2134 & 7 & convex & NE & good & felsenmeer \\
\hline $1 \mathrm{P} 4$ & 2118 & 6 & concave & NW & good & felsenmeer \\
\hline 1P5 & 2164 & 15 & convex & $N$ & good & felsenmeer \\
\hline 1P6 & 2118 & 17 & convex & NW & good & felsenmeer \\
\hline $1 \mathrm{P} 7$ & 2134 & 23 & convex & $S$ & good & felsenmeer \\
\hline $1 \mathrm{P} 8$ & 2073 & 17 & rectilinear & S & good & felsenmeer \\
\hline $1 \mathrm{Pg}$ & 2103 & 13 & concave & sW & good & felsenmeer \\
\hline 1Q1 & 2103 & 15 & convex & SE & good & felsenmeer \\
\hline 1Q2 & 2073 & 6 & convex & $E$ & good & felsenmeer \\
\hline 1Q3 & 2103 & 8 & rectilinear & $w$ & good & felsenmeer \\
\hline 1Q4 & 2103 & 6 & convex & $w$ & good & felsenmeer \\
\hline $1 Q 5$ & 2134 & 16 & convex & $W$ & good & felsenmeer \\
\hline $1 Q 6$ & 2103 & 15 & convex & SW & good & upper tundra \\
\hline $1 Q 7$ & 2073 & 6 & convex & $w$ & good & upper tundra \\
\hline $1 Q 8$ & 2103 & 11 & convex & $w$ & good & upper tundra \\
\hline $1 Q 9$ & 2073 & 11 & convex & $E$ & good & upper tundra \\
\hline
\end{tabular}

\section{Zone 2 Sites}

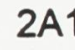

2A2

$2 \mathrm{~A} 3$

2A4

2A5

$2 \mathrm{~A} 6$

2A7

$2 A 8$

$2 A 9$

2A10

2B1

2B2
1920

1829

1920

1996

2103

2134

2164

2134

2134

2164

2134

2134

\section{3}

38

5

8

5

0

0

5

0

0

8

0

$\begin{array}{cc}\text { concave } & N \\ \text { convex } & S E \\ \text { concave } & S \\ \text { rectlinear } & E \\ \text { rectilinear } & E \\ \text { flat } & \text { flat } \\ \text { flat } & \text { flat } \\ \text { concave } & E \\ \text { flat } & \text { fla } \\ \text { flat } & \text { flat } \\ \text { rectilinear } & N \\ \text { flat } & N\end{array}$

$\begin{array}{ccc}\text { N } & \text { poor } & \text { upper tundra } \\ \text { SE } & \text { good } & \text { upper tundra } \\ \text { S } & \text { moderate } & \text { upper tundra } \\ \text { E } & \text { good } & \text { upper tundra } \\ \text { E } & \text { good } & \text { upper tundra } \\ \text { flat } & \text { fair } & \text { upper tundra } \\ \text { flat } & \text { good } & \text { upper tundra } \\ \text { E } & \text { good } & \text { upper tundra } \\ \text { flat } & \text { good } & \text { upper tundra } \\ \text { flat } & \text { good } & \text { upper tundra } \\ \text { N } & \text { good } & \text { felsenmeer } \\ \text { N } & \text { fair } & \text { upper tundra }\end{array}$


A-4

\begin{tabular}{|c|c|c|c|c|c|c|}
\hline Site No. & Elevation $(\mathrm{m})$ & Slope (deg) & Slope Shape & Site Aspect & Drainage & Cover Class \\
\hline 2B3 & 2164 & 12 & unrecorded & NW & good & felsenmeer \\
\hline 2B4 & 2195 & 22 & convex & W & good & upper tundra \\
\hline $2 B 5$ & 2197 & 0 & flat & flat & good & felsenmeer \\
\hline $2 \mathrm{C} 1$ & 1722 & 30 & unrecorded & SW & good & lower tundra \\
\hline $2 \mathrm{C} 2$ & 1859 & 17 & unrecorded & S & good & upper tundra \\
\hline $2 \mathrm{C} 3$ & 1951 & 21 & concave & SW & good & upper tundra \\
\hline $2 \mathrm{C} 4$ & 2027 & 0 & flat & flat & unrecorded & upper tundra \\
\hline $2 \mathrm{C5}$ & 2088 & 10 & unrecorded & $S$ & good & upper tundra \\
\hline 2D1 & 1189 & 13 & convex & S & good & lower tundra \\
\hline 2D2 & 1286 & 12 & convex & S & good & lower tundra \\
\hline $2 \mathrm{D} 3$ & 1402 & 38 & concave & $S$ & good & lower tundra \\
\hline 2D4 & 1494 & 22 & concave & NW & good & lower tundra \\
\hline 2D5 & 1554 & 0 & flat & NE & good & lower tundra \\
\hline 2D6 & 1646 & 7 & rectilinear & SW & good & lower tundra \\
\hline 2D7 & 1737 & 5 & rectilinear & W & good & lower tundra \\
\hline 2D8 & 1859 & 5 & concave & W & good & upper tundra \\
\hline 2D9 & 1920 & 15 & concave & S & good & upper tundra \\
\hline 2D10 & 2036 & 15 & rectilinear & $S$ & good & upper tundra \\
\hline 2D11 & 2073 & 3 & unrecorded & $S$ & good & upper tundra \\
\hline $2 \mathrm{D} 12$ & 2103 & 0 & flat & flat & good & upper tundra \\
\hline $2 \mathrm{E} 1$ & 1244 & 11 & concave & $N$ & poor & lower willow \\
\hline $2 \mathrm{E} 2$ & 1341 & 18 & convex & $\mathrm{N}$ & fair & lower tundra \\
\hline $2 E 3$ & 1433 & 23 & convex & $\mathrm{N}$ & fair & upper tundra \\
\hline $2 E 4$ & 1524 & 19 & convex & NW & good & lower tundra \\
\hline $2 \mathrm{E} 5$ & 1615 & 27 & convex & NW & good & lower tundra \\
\hline $2 E 6$ & 1707 & 19 & concave & $w$ & good & lower tundra \\
\hline $2 \mathrm{E} 7$ & 1829 & 25 & convex & W & good & upper tundra \\
\hline $2 \mathrm{E} 8$ & 1920 & 0 & flat & flat & good & upper tundra \\
\hline $2 \mathrm{~F} 1$ & 1384 & 0 & flat & SW & good & lower tundra \\
\hline $2 \mathrm{~F} 2$ & 1463 & 20 & convex & SW & good & lower tundra \\
\hline $2 \mathrm{~F} 3$ & 1542 & 24 & convex & SE & good & lower tundra \\
\hline $2 \mathrm{~F} 4$ & 1646 & 12 & convex & SW & good & lower tundra \\
\hline $2 \mathrm{~F} 5$ & 1762 & 12 & convex & $S$ & good & lower tundra \\
\hline $2 \mathrm{~F} 6$ & 1829 & 6 & convex & S & good & upper tundra \\
\hline $2 \mathrm{~F} 7$ & 1920 & 11 & convex & $S$ & good & upper tundra \\
\hline $2 F 8$ & 2012 & 12 & convex & $S$ & good & upper tundra \\
\hline $2 \mathrm{~F} 9$ & 2073 & 17 & convex & $S$ & good & upper tundra \\
\hline $2 \mathrm{~F} 10$ & 2164 & 0 & flat & flat & good & felsenmeer \\
\hline
\end{tabular}




\section{Appendix B : Relative Mineral Abundance Data}

Part 1 : 30 Muscovte-Schist Bedrock Samples

(Based on 12-peak average normalization)

\begin{tabular}{|c|c|c|c|c|c|c|c|}
\hline Sample \# & Elev.(m) & $14.2 \AA$ & $7 \AA$ & $10 \AA$ & $5 \AA$ & $3.19 \AA$ & $4.26 \AA$ \\
\hline $1 \mathrm{~A} 1(\mathrm{R})$ & 1874 & 0.44 & 2.39 & 1.01 & 0.54 & 2.18 & 0.29 \\
\hline $1 A 5(R)$ & 1615 & 0.20 & 1.17 & 1.14 & 0.74 & 0.23 & 0.72 \\
\hline $1 A 7(R)$ & 1387 & 0.44 & 2.54 & 0.92 & 0.59 & 1.20 & 0.35 \\
\hline $1 \mathrm{~B} 15(\mathrm{~F})$ & 1951 & 0.45 & 2.86 & 0.51 & 0.33 & 1.39 & 0.30 \\
\hline 1B11(R) & 1798 & 0.26 & 1.55 & 0.66 & 0.49 & 0.97 & 0.66 \\
\hline 1B6(R) & 1311 & 0.27 & 2.51 & 0.57 & 0.50 & 1.25 & 0.48 \\
\hline $1 \mathrm{C} 12(\mathrm{R})$ & 1859 & 0.37 & 2.31 & 0.69 & 0.42 & 1.04 & 0.50 \\
\hline 1C3(R) & 1128 & 0.33 & 1.73 & 0.59 & 0.46 & 1.37 & 0.71 \\
\hline 1D6(R)(2) & 1951 & 0.35 & 2.18 & 0.86 & 0.47 & 0.99 & 0.49 \\
\hline 1D6(R)(1) & 1951 & 0.36 & 2.54 & 1.02 & 0.60 & 0.58 & 0.48 \\
\hline 1D4(R) & 1859 & 0.34 & 2.23 & 1.41 & 0.82 & 0.60 & 0.48 \\
\hline 1D2(R) & 1661 & 0.30 & 1.91 & 0.89 & 0.56 & 0.69 & 0.53 \\
\hline $1 E 1(R)$ & 1841 & 0.26 & 1.74 & 0.39 & 0.22 & 2.89 & 0.55 \\
\hline $1 F 2(R)(1)$ & 1798 & 0.34 & 1.44 & 0.52 & 0.26 & 0.24 & 0.96 \\
\hline $1 F 2(R)(2)$ & 1798 & 0.34 & 2.04 & 0.87 & 0.50 & 0.36 & 0.58 \\
\hline 1F3(R) & 1896 & 0.30 & 1.82 & 0.68 & 0.28 & 0.72 & 0.59 \\
\hline $1 G 1(R)$ & 2149 & 0.39 & 2.10 & 0.18 & 0.06 & 0.56 & 0.82 \\
\hline $1 \mathrm{H} 5(\mathrm{R})$ & 1326 & 0.41 & 2.40 & 1.17 & 0.63 & 1.00 & 0.37 \\
\hline $1 \mathrm{H} 6(\mathrm{R})$ & 1402 & 0.39 & 2.27 & 0.77 & 0.36 & 1.17 & 0.65 \\
\hline $1 \mathrm{H} 8(\mathrm{R})$ & 1554 & 0.34 & 2.06 & 1.00 & 0.53 & 1.09 & 0.42 \\
\hline $1 \mathrm{H} 9(\mathrm{R})$ & 1664 & 0.33 & 1.85 & 0.63 & 0.37 & 0.88 & 0.73 \\
\hline 1J1(R) & 1128 & 0.39 & 2.56 & 1.29 & 0.75 & 0.57 & 0.37 \\
\hline 1J3(R) & 1113 & 0.50 & 2.70 & 0.40 & 0.21 & 1.38 & 0.55 \\
\hline $1 \mathrm{~K} 1(\mathrm{R})$ & 2195 & 0.41 & 2.31 & 0.92 & 0.53 & 0.77 & 0.46 \\
\hline $1 K 2(R)$ & 2316 & 0.29 & 1.70 & 0.95 & 0.56 & 1.35 & 0.63 \\
\hline $1 \mathrm{~K} 4(\mathrm{R})$ & 2286 & 0.30 & 1.71 & 0.98 & 0.53 & 0.71 & 0.68 \\
\hline $1 K 7(R)$ & 2013 & 0.36 & 2.08 & 1.04 & 0.54 & 0.73 & 0.54 \\
\hline $1 \mathrm{~K} 8(\mathrm{R})$ & 2134 & 0.34 & 2.14 & 1.03 & 0.62 & 0.63 & 0.66 \\
\hline $1 \mathrm{~K} 9(\mathrm{R})$ & 2158 & 0.43 & 2.35 & 0.71 & 0.41 & 0.52 & 0.57 \\
\hline $1 \mathrm{~K} 10$ (R) & 2195 & 0.44 & 2.75 & 1.09 & 0.70 & 0.58 & 0.37 \\
\hline Means & & .36 & 2.13 & .83 & .49 & .95 & .55 \\
\hline
\end{tabular}

Part 2 : 102 Fine-Fraction Muscovite-Bearing Samples

(see next page) 
Part 2 : 102 Fine-Fraction Muscovite-Bearing Samples

(Based on 12-peak average normalization)

Samples grouped by ground surface zone

\begin{tabular}{|c|c|c|c|c|c|c|c|c|}
\hline Sample \# & Elev. (m) & $14.2 \AA$ & $7 \AA$ & $10 \AA$ & $5 \AA$ & $3.19 \AA$ & $4.26 \AA$ & $8.4 \AA$ \\
\hline \multicolumn{9}{|l|}{ Pre-Nisling } \\
\hline 1G1a & 2149 & 0.29 & 1.55 & 0.60 & 0.39 & 0.95 & 0.76 & 0.10 \\
\hline $1 \mathrm{G} 2 \mathrm{a}$ & 2131 & 0.42 & 2.35 & 0.96 & 0.59 & 0.56 & 0.57 & 0.05 \\
\hline $1 \mathrm{G} 3 \mathrm{a}$ & 2088 & 0.50 & 2.43 & 0.77 & 0.57 & 0.59 & 0.46 & 0.04 \\
\hline $1 \mathrm{G} 4 \mathrm{a}$ & 2100 & 0.46 & 2.49 & 0.85 & 0.51 & 0.47 & 0.54 & 0.03 \\
\hline $1 \mathrm{~K} 1 \mathrm{a}$ & 2195 & 0.41 & 2.43 & 1.12 & 0.62 & 0.38 & 0.38 & 0.00 \\
\hline $1 \mathrm{~K} 2 \mathrm{a}$ & 2316 & 0.27 & 1.17 & 1.34 & 0.76 & 0.68 & 0.82 & 0.04 \\
\hline $1 \mathrm{~K} 3 \mathrm{a}$ & 2286 & 0.34 & 1.66 & 0.84 & 0.45 & 0.96 & 0.74 & 0.00 \\
\hline $1 \mathrm{~K} 4 \mathrm{a}$ & 2286 & 0.37 & 1.88 & 0.92 & 0.54 & 0.65 & 0.51 & 0.09 \\
\hline $1 \mathrm{~K} 5 \mathrm{a}$ & 2225 & 0.40 & 2.00 & 1.11 & 0.65 & 0.85 & 0.57 & 0.00 \\
\hline $1 \mathrm{~K} 6 \mathrm{a}$ & 2195 & 0.38 & 1.86 & 1.00 & 0.57 & 0.89 & 0.64 & 0.00 \\
\hline $1 \mathrm{~K} 7 \mathrm{a}$ & 2103 & 0.34 & 1.66 & 0.82 & 0.43 & 0.67 & 1.01 & 0.00 \\
\hline $1 \mathrm{~K} 8 \mathrm{a}$ & 2134 & 0.30 & 1.63 & 0.64 & 0.41 & 0.93 & 0.59 & 0.09 \\
\hline $1 \mathrm{~K} 9 \mathrm{a}$ & 2158 & 0.37 & 1.89 & 0.73 & 0.43 & 1.08 & 0.61 & 0.10 \\
\hline $1 \mathrm{~K} 10 \mathrm{a}$ & 2195 & 0.33 & 1.84 & 0.85 & 0.53 & 1.10 & 0.61 & 0.05 \\
\hline 1L11a & 2316 & 0.29 & 0.94 & 0.54 & 0.31 & 0.82 & 0.96 & 0.00 \\
\hline 1L12a & 2262 & 0.55 & 0.88 & 0.64 & 0.27 & 1.08 & 1.05 & 0.06 \\
\hline 1L13a & 2170 & 0.36 & 1.38 & 0.87 & 0.50 & 0.57 & 0.97 & 0.00 \\
\hline 1P1a & 2134 & 0.24 & 1.25 & 0.50 & 0.31 & 1.16 & 0.96 & 0.12 \\
\hline $1 \mathrm{P} 2 \mathrm{a}$ & 2088 & 0.30 & 1.32 & 0.59 & 0.30 & 1.20 & 0.98 & 0.22 \\
\hline $1 \mathrm{P} 3 \mathrm{a}$ & 2134 & 0.41 & 1.50 & 0.22 & 0.19 & 0.94 & 0.71 & 0.04 \\
\hline $1 \mathrm{P} 4 \mathrm{a}$ & 2103 & 0.35 & 1.87 & 0.54 & 0.31 & 1.27 & 0.74 & 0.06 \\
\hline $1 \mathrm{P} 5 \mathrm{a}$ & 2164 & 0.32 & 1.68 & 0.68 & 0.35 & 0.85 & 0.93 & 0.50 \\
\hline 1P6a & 2118 & 0.30 & 1.28 & 0.72 & 0.40 & 1.06 & 0.82 & 0.04 \\
\hline $1 \mathrm{P} 7 \mathrm{a}$ & 2134 & 0.26 & 1.17 & 0.49 & 0.26 & 1.20 & 1.17 & 0.13 \\
\hline 1P8a & 2073 & 0.31 & 0.96 & 0.68 & 0.56 & 1.05 & 0.80 & 0.00 \\
\hline $1 \mathrm{P9a}$ & 2103 & 0.31 & 1.79 & 0.70 & 0.40 & 0.66 & 0.94 & 0.00 \\
\hline 1Q1a & 2103 & 0.38 & 1.56 & 0.64 & 0.33 & 1.24 & 0.65 & 0.02 \\
\hline 1Q2a & 2073 & 0.28 & 1.39 & 0.56 & 0.29 & 1.49 & 0.77 & 0.23 \\
\hline 1Q3a & 2103 & 0.29 & 1.28 & 0.45 & 0.28 & 1.38 & 0.97 & 0.24 \\
\hline 1Q4a & 2103 & 0.41 & 1.74 & 0.49 & 0.29 & 0.96 & 0.65 & 0.05 \\
\hline $1 Q 5 a$ & 2134 & 0.33 & 1.58 & 0.61 & 0.36 & 0.85 & 0.64 & 0.03 \\
\hline 1Q6a & 2103 & 0.36 & 1.52 & 0.62 & 0.34 & 1.04 & 0.60 & 0.06 \\
\hline $1 Q 7 a$ & 2073 & 0.48 & 1.68 & 0.50 & 0.32 & 0.76 & 0.68 & 0.03 \\
\hline 1Q8a & 2103 & 0.18 & 0.90 & 0.44 & 0.15 & 1.88 & 0.90 & 0.23 \\
\hline $1 Q 9 a$ & 2073 & 0.35 & 1.33 & 0.67 & 0.38 & 1.00 & 1.02 & 0.09 \\
\hline \multicolumn{9}{|l|}{ Nisling } \\
\hline $\begin{array}{l}1 \mathrm{~A} 2 \mathrm{a} \\
1 \mathrm{~A} 3 \mathrm{a}\end{array}$ & $\begin{array}{l}1836 \\
1768\end{array}$ & $\begin{array}{l}0.23 \\
0.31\end{array}$ & 1.65 & 0.90 & 0.64 & 1.05 & 0.53 & 0.09 \\
\hline
\end{tabular}




\begin{tabular}{|c|c|c|c|c|c|c|c|c|}
\hline Sample \# & Elev. (m) & $14.2 \AA$ & $7 \AA$ & $10 \AA$ & $5 \AA$ & $3.19 \AA$ & $4.26 \AA$ & $8.4 \AA$ \\
\hline $1 \mathrm{~A} 4 \mathrm{a}$ & 1676 & 0.29 & 1.71 & 0.73 & 0.51 & 1.55 & 0.69 & 0.53 \\
\hline $1 \mathrm{~A} 6 \mathrm{a}$ & 1432 & 0.32 & 2.10 & 0.98 & 0.63 & 1.11 & 0.47 & 0.05 \\
\hline 1B15a & 1951 & 0.40 & 2.39 & 0.83 & 0.59 & 0.92 & 0.48 & 0.04 \\
\hline $1 \mathrm{~B} 14 \mathrm{a}$ & 1957 & 0.35 & 1.89 & 1.05 & 0.51 & 1.22 & 0.59 & 0.08 \\
\hline $1 \mathrm{~B} 13 \mathrm{a}$ & 1890 & 0.32 & 1.91 & 0.32 & 0.24 & 1.50 & 0.64 & 0.32 \\
\hline $1 \mathrm{~B} 12 \mathrm{a}$ & 1829 & 0.25 & 1.28 & 0.68 & 0.39 & 1.61 & 0.75 & 0.21 \\
\hline 1B11a & 1798 & 0.22 & 1.37 & 0.82 & 0.43 & 1.63 & 0.99 & 0.34 \\
\hline $1 \mathrm{~B} 10 \mathrm{a}$ & 1676 & 0.25 & 1.20 & 0.75 & 0.42 & 2.32 & 0.71 & 0.37 \\
\hline $189 a$ & 1584 & 0.28 & 1.34 & 0.56 & 0.28 & 1.28 & 0.81 & 0.12 \\
\hline $1 \mathrm{B8a}$ & 1493 & 0.39 & 1.65 & 0.84 & 0.46 & 1.48 & 0.67 & 0.28 \\
\hline $1 \mathrm{C} 12 \mathrm{a}$ & 1798 & 0.20 & 0.95 & 0.38 & 0.29 & 1.21 & 0.96 & 0.18 \\
\hline $1 \mathrm{C} 11 \mathrm{a}$ & 1676 & 0.20 & 1.27 & 0.55 & 0.44 & 1.25 & 0.83 & 0.10 \\
\hline $1 \mathrm{C} 10 \mathrm{a}$ & 1615 & 0.30 & 1.75 & 0.77 & 0.47 & 1.51 & 0.66 & 0.19 \\
\hline $1 \mathrm{Cg}$ & 1585 & 0.19 & 0.82 & 0.33 & 0.19 & 2.00 & 0.84 & 0.35 \\
\hline $1 \mathrm{C} 8 \mathrm{a}$ & 1493 & 0.24 & 1.25 & 0.51 & 0.31 & 1.24 & 0.85 & 0.06 \\
\hline $1 \mathrm{D6a}(2)$ & 1951 & 0.43 & 2.23 & 0.81 & 0.65 & 0.62 & 0.44 & 0.05 \\
\hline $1 \mathrm{D} 6 \mathrm{a}(1)$ & 1951 & 0.39 & 1.93 & 1.05 & 0.56 & 0.73 & 0.69 & 0.00 \\
\hline $1 D 5 a$ & 1920 & 0.36 & 1.96 & 0.84 & 0.50 & 1.12 & 0.61 & 0.25 \\
\hline $1 \mathrm{D} 4 \mathrm{a}$ & 1859 & 0.42 & 2.07 & 0.97 & 0.59 & 1.27 & 0.40 & 0.21 \\
\hline 1E1a & 1841 & 0.35 & 2.28 & 0.92 & 0.64 & 0.91 & 0.44 & 0.03 \\
\hline 1D3a & 1768 & 0.33 & 1.67 & 0.65 & 0.44 & 0.88 & 0.67 & 0.15 \\
\hline $1 \mathrm{D} 2 \mathrm{a}$ & 1661 & 0.21 & 1.04 & 0.35 & 0.23 & 1.50 & 1.02 & 0.23 \\
\hline 1D1a & 1597 & 0.31 & 1.77 & 0.90 & 0.73 & 1.82 & 0.48 & 0.36 \\
\hline $1 \mathrm{~F} 1 \mathrm{a}$ & 1719 & 0.25 & 0.80 & 0.20 & 0.10 & 4.15 & 0.70 & 0.80 \\
\hline $1 F 2 a$ & 1798 & 0.21 & 1.33 & 0.67 & 0.38 & 0.90 & 0.78 & 0.14 \\
\hline 1F3a & 1798 & 0.50 & 2.23 & 0.83 & 0.45 & 0.79 & 0.55 & 0.16 \\
\hline $1 \mathrm{H} 7 \mathrm{a}$ & 1469 & 0.25 & 1.17 & 0.41 & 0.25 & 1.01 & 0.89 & 0.13 \\
\hline $1 \mathrm{H} 8 \mathrm{a}$ & 1554 & 0.27 & 0.94 & 0.48 & 0.35 & 0.95 & 0.94 & 0.14 \\
\hline $1 \mathrm{H} 9 \mathrm{a}$ & 1664 & 0.29 & 1.02 & 0.35 & 0.24 & 1.40 & 0.99 & 0.22 \\
\hline \multicolumn{9}{|l|}{ Ruby } \\
\hline $1 \mathrm{~A} 7 \mathrm{a}$ & 1387 & 0.38 & 2.53 & 0.95 & 0.61 & 1.03 & 0.47 & 0.15 \\
\hline $1 \mathrm{~A} 8 \mathrm{a}(1)$ & 1295 & 0.36 & 1.77 & 0.83 & 0.38 & 1.54 & 0.60 & 0.25 \\
\hline $1 \mathrm{~A} 8 \mathrm{a}(2)$ & 1295 & 0.21 & 1.26 & 0.45 & 0.31 & 1.33 & 0.80 & 0.15 \\
\hline $1 \mathrm{~A} 10 \mathrm{a}$ & 1189 & 0.33 & 1.98 & 0.59 & 0.34 & 2.05 & 0.45 & 0.10 \\
\hline $1 \mathrm{~B} 7 \mathrm{a}$ & 1402 & 0.29 & 1.61 & 0.82 & 0.60 & 1.33 & 0.60 & 0.44 \\
\hline 1B6a & 1311 & 0.39 & 1.73 & 0.91 & 0.49 & 1.83 & 0.62 & 0.20 \\
\hline $1 \mathrm{~B} 5 \mathrm{a}$ & 1219 & 0.27 & 0.86 & 0.64 & 0.38 & 2.09 & 0.86 & 0.54 \\
\hline $1 \mathrm{~B} 4 \mathrm{a}$ & 1128 & 0.26 & 1.17 & 0.48 & 0.26 & 1.55 & 1.04 & 0.17 \\
\hline $\begin{array}{l}1 C 7 a \\
1 C 6 a\end{array}$ & $\begin{array}{l}1402 \\
1372\end{array}$ & $\begin{array}{l}0.38 \\
0.32\end{array}$ & $\begin{array}{l}1.55 \\
0.97\end{array}$ & $\begin{array}{l}0.40 \\
0.28\end{array}$ & 0.16 & 2.05 & 1.01 & 0.37 \\
\hline $\begin{array}{l}1 \mathrm{C} 6 \mathrm{a} \\
1 \mathrm{C} 5 \mathrm{a}\end{array}$ & $\begin{array}{l}1372 \\
1311\end{array}$ & $\begin{array}{l}0.32 \\
0.25\end{array}$ & 1.22 & 0.56 & 0.29 & 1.11 & 1.04 & 0.16 \\
\hline $\begin{array}{l}1 \mathrm{C} 5 \mathrm{a} \\
1 \mathrm{C} 4 \mathrm{a}\end{array}$ & $\begin{array}{l}1311 \\
1219\end{array}$ & 0.53 & 2.41 & 0.29 & 0.17 & 0.95 & 0.51 & 0.11 \\
\hline $\begin{array}{l}1 \mathrm{C} 4 \mathrm{a} \\
1 \mathrm{C} 3 \mathrm{a}\end{array}$ & 1128 & 0.24 & 1.56 & 0.98 & 0.53 & 1.36 & 0.56 & 0.08 \\
\hline $\begin{array}{l}1 \mathrm{C} 3 a \\
1 \mathrm{H} 3 \mathrm{a}\end{array}$ & 1143 & 0.21 & 0.52 & 0.21 & 0.11 & 1.57 & 1.32 & 0.32 \\
\hline
\end{tabular}




\begin{tabular}{|c|c|c|c|c|c|c|c|c|}
\hline & & & & & & & & B- \\
\hline Sample \# & Elev. (m) & $14.2 \AA$ & $7 \AA$ & $10 \AA$ & $5 \AA$ & $3.19 \AA$ & $4.26 \AA$ & $8.4 \AA$ \\
\hline $1 \mathrm{H} 4 \mathrm{a}$ & 1219 & 0.20 & 0.74 & 0.30 & 0.17 & 1.27 & 0.94 & 0.31 \\
\hline $1 \mathrm{H} 5 \mathrm{a}$ & 1326 & 0.21 & 0.97 & 0.46 & 0.26 & 2.12 & 0.70 & 0.09 \\
\hline $1 \mathrm{H} 6 \mathrm{a}$ & 1402 & 0.31 & 1.83 & 0.81 & 0.33 & 0.74 & 0.54 & 0.12 \\
\hline 1J1a & 1128 & 0.28 & 0.59 & 0.25 & 0.16 & 1.86 & 1.04 & 0.36 \\
\hline $1 \mathrm{~J} 2 \mathrm{a}$ & 1109 & 0.27 & 0.41 & 0.21 & 0.14 & 1.46 & 1.16 & 0.41 \\
\hline $1 \mathrm{~J} 3 \mathrm{a}$ & 1113 & 0.34 & 0.99 & 0.50 & 0.22 & 1.15 & 0.59 & 0.22 \\
\hline \multicolumn{9}{|l|}{ Post-glacial } \\
\hline $1 \mathrm{~A} 11 \mathrm{a}$ & 1097 & 0.36 & 1.97 & 0.58 & 0.34 & 1.40 & 0.62 & 0.04 \\
\hline $1 \mathrm{~A} 12 \mathrm{a}$ & 991 & 0.28 & 1.58 & 0.78 & 0.50 & 1.29 & 0.64 & 0.09 \\
\hline $1 \mathrm{~A} 13 \mathrm{a}$ & 914 & 0.12 & 0.57 & 0.18 & 0.12 & 1.59 & 1.10 & 0.20 \\
\hline $1 \mathrm{~A} 14 \mathrm{a}$ & 869 & 0.16 & 0.76 & 0.36 & 0.14 & 1.48 & 1.06 & 0.30 \\
\hline 1B3a & 1036 & 0.33 & 1.40 & 0.77 & 0.33 & 1.18 & 0.81 & 0.15 \\
\hline $1 \mathrm{~B} 2 \mathrm{a}$ & 945 & 0.25 & 1.41 & 0.51 & 0.40 & 1.34 & 0.80 & 0.33 \\
\hline 1B1a & 853 & 0.24 & 1.30 & 0.50 & 0.35 & 1.39 & 0.93 & 0.26 \\
\hline $1 \mathrm{C} 2 \mathrm{a}$ & 1036 & 0.21 & 0.61 & 0.16 & 0.11 & 1.48 & 1.10 & 0.17 \\
\hline $1 \mathrm{C} 1 \mathrm{a}$ & 945 & 0.22 & 0.94 & 0.37 & 0.17 & 1.46 & 1.11 & 0.22 \\
\hline $1 \mathrm{H} 1 \mathrm{a}$ & 945 & 0.22 & 0.62 & 0.32 & 0.17 & 1.54 & 1.13 & 0.24 \\
\hline $1 \mathrm{H} 2 \mathrm{a}$ & 1036 & 0.18 & 0.47 & 0.20 & 0.11 & 1.66 & 1.11 & 0.20 \\
\hline $1 \mathrm{M} 1 \mathrm{a}$ & 823 & 0.28 & 1.04 & 0.43 & 0.20 & 1.41 & 0.97 & 0.27 \\
\hline $1 \mathrm{M} 2 \mathrm{a}$ & 838 & 0.22 & 0.81 & 0.42 & 0.20 & 1.63 & 1.06 & 0.26 \\
\hline $1 \mathrm{M} 3 \mathrm{a}$ & 1036 & 0.23 & 0.79 & 0.34 & 0.18 & 1.35 & 0.99 & 0.18 \\
\hline $1 \mathrm{M} 4 \mathrm{a}$ & 860 & 0.18 & 0.59 & 0.35 & 0.13 & 1.54 & 1.38 & 0.18 \\
\hline
\end{tabular}

Part 3 : Muscovite/Biotite Depletion Data

(see next page) 
Part 3 : Muscovite/Biotite Depletion Data

(Based on calculated areas under the $10-14 \AA$ X-ray diffraction peaks)

\begin{tabular}{|c|c|c|c|}
\hline \multicolumn{4}{|c|}{ Biotite Depletion } \\
\hline \multicolumn{2}{|c|}{ Bedrock Samples* } & \multicolumn{2}{|c|}{ Fine-Fraction Samples ${ }^{\star \star \star}$} \\
\hline Site & $10 \AA\left(\mathrm{mm}^{2}\right)$ & Site & $10-14 \AA\left(\mathrm{mm}^{2}\right)$ \\
\hline $1 \mathrm{~L} 1$ & 1125 & $1 \mathrm{LT}$ & 414 \\
\hline $1 \mathrm{~L} 6$ & 750 & 1L5 & 260 \\
\hline $1 L 7$ & 453 & $1 \mathrm{~L} 2$ & 397 \\
\hline 1L9R & 726 & 1L8 & 460 \\
\hline Mean $\Rightarrow$ & 764 & \multicolumn{2}{|l|}{ Mean $\Rightarrow$} \\
\hline \multicolumn{4}{|l|}{ Depletion(\%) $\Rightarrow$} \\
\hline \multicolumn{4}{|c|}{ Muscovite Depletion } \\
\hline \multicolumn{2}{|c|}{ Bedrock Samples ${ }^{*}$} & \multicolumn{2}{|c|}{ Fine-Fraction Samples ${ }^{\star \star}$} \\
\hline Site & $10 \AA\left(\mathrm{mm}^{2}\right)$ & Site & $10-14 \AA\left(\mathrm{mm}^{2}\right)$ \\
\hline $1 \mathrm{~K} 4$ & 205 & $1 \mathrm{~K} 6$ & 200.5 \\
\hline $1 \mathrm{~K} 1$ & 291 & $1 \mathrm{~K} 4$ & 144 \\
\hline $1 \mathrm{~K} 2$ & 160 & $1 \mathrm{~K} 3$ & 200 \\
\hline $1 \mathrm{~K} 9$ & 136 & $1 \mathrm{~K} 7$ & 135 \\
\hline Mean $\Rightarrow$ & 198 & \multirow[t]{2}{*}{ Mean $\Rightarrow$} & 170 \\
\hline \multicolumn{3}{|l|}{ Depletion(\%) $\Rightarrow$} & \\
\hline * includes area under th & eak only & & \\
\hline ** includes area under th & ak plus the & der whict & n $10-14 \AA$ \\
\hline
\end{tabular}

Part 4 : Fine-Fraction Muscovite-Bearing Samples

Samples arranged in descending order of elevation

(see next page) 
B-6

Part 4 : Fine-Fraction Muscovite-Bearing Samples

(Based on 12-peak average normalization)

Samples arranged in descending order of elevation

\begin{tabular}{|c|c|c|c|c|c|c|c|c|}
\hline Site & Elev.(m) & Slope(deg) & Aspect & $7 \AA$ & $5 \AA$ & $4.26 \AA$ & $8.4 \AA$ & $3.19 \AA$ \\
\hline $1 \mathrm{~K} 2$ & 2316 & 0 & ALL & 1.17 & 0.76 & 0.82 & 0.04 & 0.68 \\
\hline 1L11 & 2316 & 19 & W & 0.94 & 0.31 & 0.96 & 0.00 & 0.82 \\
\hline $1 \mathrm{~K} 3$ & 2286 & 12 & SW & 1.66 & 0.45 & 0.74 & 0.00 & 0.96 \\
\hline $1 \mathrm{~K} 4$ & 2286 & 12 & NE & 1.88 & 0.54 & 0.51 & 0.09 & 0.65 \\
\hline 1L12 & 2262 & 23 & $S$ & 0.88 & 0.27 & 1.05 & 0.06 & 1.08 \\
\hline $1 \mathrm{~K} 5$ & 2225 & 10 & S & 2.00 & 0.65 & 0.57 & 0.00 & 0.85 \\
\hline $1 \mathrm{~K} 1$ & 2195 & 25 & NW & 2.43 & 0.62 & 0.38 & 0.00 & 0.38 \\
\hline $1 \mathrm{~K} 10$ & 2195 & 34 & $E$ & 1.84 & 0.53 & 0.61 & 0.05 & 1.10 \\
\hline $1 \mathrm{~K} 6$ & 2195 & 18 & S & 1.86 & 0.57 & 0.64 & 0.00 & 0.89 \\
\hline $1 L 13$ & 2170 & 14 & S & 1.38 & 0.50 & 0.97 & 0.00 & 0.57 \\
\hline 1P5 & 2164 & 15 & $\mathrm{~N}$ & 1.68 & 0.35 & 0.93 & 0.50 & 0.85 \\
\hline $1 \mathrm{~K} 9$ & 2158 & 25 & $\mathrm{~N}$ & 1.89 & 0.43 & 0.61 & 0.10 & 1.08 \\
\hline $1 \mathrm{G} 1$ & 2149 & 0 & SW & 1.55 & 0.39 & 0.76 & 0.10 & 0.95 \\
\hline $1 \mathrm{~K} 8$ & 2134 & 43 & W & 1.63 & 0.41 & 0.59 & 0.09 & 0.93 \\
\hline 1P1 & 2134 & 31 & SE & 1.25 & 0.31 & 0.96 & 0.12 & 1.16 \\
\hline $1 \mathrm{P3}$ & 2134 & 7 & NE & 1.50 & 0.19 & 0.71 & 0.04 & 0.94 \\
\hline $1 \mathrm{P} 7$ & 2134 & 23 & $S$ & 1.17 & 0.26 & 1.17 & 0.13 & 1.20 \\
\hline $1 Q 5$ & 2134 & 16 & $w$ & 1.58 & 0.36 & 0.64 & 0.03 & 0.85 \\
\hline $1 \mathrm{G} 2$ & 2131 & 0 & $S$ & 2.35 & 0.59 & 0.57 & 0.05 & 0.56 \\
\hline $1 \mathrm{P} 6$ & 2118 & 17 & NW & 1.28 & 0.40 & 0.82 & 0.04 & 1.06 \\
\hline $1 \mathrm{~K} 7$ & 2103 & 18 & SE & 1.66 & 0.43 & 1.01 & 0.00 & 0.67 \\
\hline $1 P 4$ & 2103 & 6 & NW & 1.87 & 0.31 & 0.74 & 0.06 & 1.27 \\
\hline $1 \mathrm{Pg}$ & 2103 & 13 & SW & 1.79 & 0.40 & 0.94 & 0.00 & 0.66 \\
\hline 1Q1 & 2103 & 15 & SE & 1.56 & 0.33 & 0.65 & 0.02 & 1.24 \\
\hline 1Q3 & 2103 & 8 & $w$ & 1.28 & 0.28 & 0.97 & 0.24 & 1.38 \\
\hline 1Q4 & 2103 & 6 & W & 1.74 & 0.29 & 0.65 & 0.05 & 0.96 \\
\hline $1 Q 6$ & 2103 & 15 & SW & 1.52 & 0.34 & 0.60 & 0.06 & 1.04 \\
\hline $1 Q 8$ & 2103 & 11 & W & 0.90 & 0.15 & 0.90 & 0.23 & 1.88 \\
\hline $1 \mathrm{G} 4$ & 2100 & 0 & $E$ & 2.49 & 0.51 & 0.54 & 0.03 & 0.47 \\
\hline $1 \mathrm{G} 3$ & 2088 & 0 & $\mathrm{E}$ & 2.43 & 0.57 & 0.46 & 0.04 & 0.59 \\
\hline 1P2 & 2088 & 25 & SE & 1.32 & 0.30 & 0.98 & 0.22 & 1.20 \\
\hline 1P8 & 2073 & 17 & $S$ & 0.96 & 0.56 & 0.80 & 0.00 & 1.05 \\
\hline 1Q2 & 2073 & 6 & $E$ & 1.39 & 0.29 & 0.77 & 0.23 & 1.49 \\
\hline $1 Q 7$ & 2073 & 6 & $\bar{W}$ & 1.68 & 0.32 & 0.68 & 0.03 & 0.76 \\
\hline $1 Q 9$ & 2073 & 11 & $E$ & 1.33 & 0.38 & 1.02 & 0.09 & 1.00 \\
\hline $1 \mathrm{~B} 14$ & 1957 & 10 & SW & 1.89 & 0.51 & 0.59 & 0.08 & 1.22 \\
\hline $1 \mathrm{~B} 15$ & 1951 & 0 & NE & 2.39 & 0.59 & 0.48 & 0.04 & 0.92 \\
\hline 1D6 & 1951 & 0 & ALL & 1.93 & 0.56 & 0.69 & 0.00 & 0.73 \\
\hline 1D5 & 1920 & 18 & $W$ & 1.96 & 0.50 & 0.61 & 0.25 & 1.12 \\
\hline $1 \mathrm{~B} 13$ & 1890 & 27 & $E$ & 1.91 & 0.24 & 0.64 & 0.32 & 1.50 \\
\hline $1 \mathrm{~A} 1$ & 1874 & 0 & $\mathrm{~N}$ & 1.52 & 0.20 & 0.84 & 0.54 & 1.47 \\
\hline 1D4 & 1859 & 21 & W & 2.07 & 0.59 & 0.40 & 0.21 & 1.27 \\
\hline $1 E 1$ & 1841 & 24 & SE & 2.28 & 0.64 & 0.44 & 0.03 & 0.91 \\
\hline $1 \mathrm{~A} 2$ & 1836 & 5 & $\mathrm{~N}$ & 1.39 & 0.31 & 0.78 & 0.09 & 1.22 \\
\hline $1 \mathrm{~B} 12$ & 1829 & 0 & S & 1.28 & 0.39 & 0.75 & 0.21 & 1.61 \\
\hline 1B11 & 1798 & 0 & sW & 1.37 & 0.43 & 0.99 & 0.34 & 1.63 \\
\hline
\end{tabular}




\begin{tabular}{|c|c|c|c|c|c|c|c|c|}
\hline Site & Elev.(m) & Slope(deg) & Aspect & $7 \AA$ & $5 \AA$ & $4.26 \AA$ & $8.4 \AA$ & $3.19 \AA$ \\
\hline 1012 & 1798 & 29 & S & 0.95 & 0.29 & 0.96 & 0.18 & 1.21 \\
\hline $1 F 2$ & 1798 & 25 & $\mathrm{~N}$ & 1.33 & 0.38 & 0.78 & 0.14 & 0.90 \\
\hline $1 F 3$ & 1798 & 16 & NW & 2.23 & 0.45 & 0.55 & 0.16 & 0.79 \\
\hline $1 \mathrm{~A} 3$ & 1768 & 20 & NE & 1.65 & 0.64 & 0.53 & 0.09 & 1.05 \\
\hline 1D3 & 1768 & 12 & W & 1.67 & 0.44 & 0.67 & 0.15 & 0.88 \\
\hline $1 \mathrm{~F} 1$ & 1719 & 0 & ALL & 0.80 & 0.10 & 0.70 & 0.80 & 4.15 \\
\hline $1 \mathrm{~A} 4$ & 1676 & 5 & $N$ & 1.71 & 0.51 & 0.69 & 0.53 & 1.55 \\
\hline $1 \mathrm{B10}$ & 1676 & 19 & SW & 1.20 & 0.42 & 0.71 & 0.37 & 2.32 \\
\hline $1 C 11$ & 1676 & 18 & SE & 1.27 & 0.44 & 0.83 & 0.10 & 1.25 \\
\hline $1 \mathrm{H} 9$ & 1664 & 7 & SW & 1.02 & 0.24 & 0.99 & 0.22 & 1.40 \\
\hline 1D2 & 1661 & 15 & W & 1.04 & 0.23 & 1.02 & 0.23 & 1.50 \\
\hline $1 \mathrm{C} 10$ & 1615 & 18 & SE & 1.75 & 0.47 & 0.66 & 0.19 & 1.51 \\
\hline 1D1 & 1597 & 0 & $N$ & 1.77 & 0.73 & 0.48 & 0.36 & 1.82 \\
\hline $1 \mathrm{C9}$ & 1585 & 9 & $w$ & 0.82 & 0.19 & 0.84 & 0.35 & 2.00 \\
\hline $1 \mathrm{B9}$ & 1584 & 14 & SW & 1.34 & 0.28 & 0.81 & 0.12 & 1.28 \\
\hline $1 \mathrm{H} 8$ & 1554 & 13 & $S$ & 0.94 & 0.35 & 0.94 & 0.14 & 0.95 \\
\hline 1B8 & 1493 & 10 & SW & 1.65 & 0.46 & 0.67 & 0.28 & 1.48 \\
\hline $1 \mathrm{C} 8$ & 1493 & 19 & SE & 1.25 & 0.31 & 0.85 & 0.06 & 1.24 \\
\hline $1 \mathrm{H} 7$ & 1469 & 0 & ALL & 1.17 & 0.25 & 0.89 & 0.13 & 1.01 \\
\hline $1 \mathrm{~A} 6$ & 1432 & 0 & SW & 2.10 & 0.63 & 0.47 & 0.05 & 1.11 \\
\hline 1B7 & 1402 & 21 & SW & 1.61 & 0.60 & 0.60 & 0.44 & 1.33 \\
\hline $1 C 7$ & 1402 & 13 & SE & 1.55 & 0.26 & 1.21 & 0.12 & 1.37 \\
\hline $1 \mathrm{H} 6$ & 1402 & 8 & $S$ & 1.83 & 0.33 & 0.54 & 0.12 & 0.74 \\
\hline $1 \mathrm{~A} 7$ & 1387 & 25 & SW & 2.53 & 0.61 & 0.47 & 0.15 & 1.03 \\
\hline $1 \mathrm{C} 6$ & 1372 & 0 & ALL & 0.97 & 0.16 & 1.01 & 0.37 & 2.05 \\
\hline 1H5 & 1326 & 28 & $S$ & 0.97 & 0.26 & 0.70 & 0.09 & 2.12 \\
\hline 1B6 & 1311 & 33 & $S$ & 1.73 & 0.49 & 0.62 & 0.20 & 1.83 \\
\hline $1 C 5$ & 1311 & 13 & $E$ & 1.22 & 0.29 & 1.04 & 0.16 & 1.11 \\
\hline $1 \mathrm{~A} 8$ & 1295 & 25 & SW & 1.77 & 0.38 & 0.60 & 0.25 & 1.54 \\
\hline 1B5 & 1219 & 26 & SW & 0.86 & 0.38 & 0.86 & 0.54 & 2.09 \\
\hline $1 C 4$ & 1219 & 19 & $E$ & 2.41 & 0.17 & 0.51 & 0.11 & 0.95 \\
\hline $1 \mathrm{H} 4$ & 1219 & 21 & $S$ & 0.74 & 0.17 & 0.94 & 0.31 & 1.27 \\
\hline $1 \mathrm{~A} 10$ & 1189 & 24 & SW & 1.98 & 0.34 & 0.45 & 0.10 & 2.05 \\
\hline $1 \mathrm{H} 3$ & 1143 & 6 & $S$ & 0.52 & 0.11 & 1.32 & 0.32 & 1.57 \\
\hline 1B4 & 1128 & 10 & SW & 1.17 & 0.26 & 1.04 & 0.17 & 1.55 \\
\hline $1 C 3$ & 1128 & 28 & $S$ & 1.56 & 0.53 & 0.56 & 0.08 & 1.36 \\
\hline 1J1 & 1128 & 8 & $S$ & 0.59 & 0.16 & 1.04 & 0.36 & 1.86 \\
\hline $1 \mathrm{~J} 3$ & 1113 & 9 & $S$ & 0.99 & 0.22 & 0.59 & 0.22 & 1.15 \\
\hline $1 \mathrm{~J} 2$ & 1109 & 5 & $S$ & 0.41 & 0.14 & 1.16 & 0.41 & 1.46 \\
\hline $1 \mathrm{~A} 11$ & 1097 & 29 & SW & 1.97 & 0.34 & 0.62 & 0.04 & 1.40 \\
\hline $1 \mathrm{B3}$ & 1036 & 22 & SW & 1.40 & 0.33 & 0.81 & 0.15 & 1.18 \\
\hline $1 \mathrm{C} 2$ & 1036 & 12 & $S$ & 0.61 & 0.11 & 1.10 & 0.17 & 1.48 \\
\hline $1 \mathrm{H} 2$ & 1036 & 45 & $w$ & 0.47 & 0.11 & 1.11 & 0.20 & 1.66 \\
\hline $1 \mathrm{M} 3$ & 1036 & 16 & SW & 0.79 & 0.18 & 0.99 & 0.18 & 1.35 \\
\hline $1 \mathrm{~A} 12$ & 991 & 15 & SW & 1.58 & 0.50 & 0.64 & 0.09 & 1.29 \\
\hline 1B2 & 945 & 12 & SW & 1.41 & 0.40 & 0.80 & 0.33 & 1.34 \\
\hline $1 \mathrm{C1}$ & 945 & 2 & $S$ & 0.94 & 0.17 & 1.11 & 0.22 & 1.46 \\
\hline $1 \mathrm{H} 1$ & 945 & 2 & $S$ & 0.62 & 0.17 & 1.13 & 0.24 & 1.54 \\
\hline $1 \mathrm{~A} 13$ & 914 & 21 & SW & 0.57 & 0.12 & 1.10 & 0.20 & 1.59 \\
\hline $1 \mathrm{~A} 14$ & 869 & 0 & SW & 0.76 & 0.14 & 1.06 & 0.30 & 1.48 \\
\hline
\end{tabular}


B-8

\begin{tabular}{cccccccccc} 
Site & Elev. $(\mathrm{m})$ & Slope (deg) & Aspect & $7 \AA$ & $5 \AA$ & $4.26 \AA$ & $8.4 \AA$ & $3.19 \AA$ \\
\hline $1 \mathrm{M} 4$ & 860 & 18 & $\mathrm{~S}$ & 0.59 & 0.13 & 1.38 & 0.18 & 1.54 \\
$1 \mathrm{~B} 1$ & 853 & 0 & $\mathrm{~W}$ & 1.30 & 0.35 & 0.93 & 0.26 & 1.39 \\
$1 \mathrm{M} 2$ & 838 & 0 & $\mathrm{SW}$ & 0.81 & 0.20 & 1.06 & 0.26 & 1.63 \\
$1 \mathrm{M} 1$ & 823 & 19 & $\mathrm{~W}$ & 1.04 & 0.20 & 0.97 & 0.27 & 1.41
\end{tabular}


Appendix C : Extractable Iron Content

(Dithionite-Citrate Extraction Method)

\begin{tabular}{|c|c|c|c|c|c|c|}
\hline Site \# & Elev.(m) & Iron(\%) & Slope(deg) & Slope Aspect & Drainage & Cover Class \\
\hline $1 A 6$ & 1432 & 1.04 & $<5$ & sw & good & upper willow \\
\hline $1 \mathrm{~A} 7$ & 1387 & 1.17 & 25 & SW & good & upper willow \\
\hline $1 \mathrm{~A} 8$ & 1295 & 1.26 & 25 & SW & good & lower tundra \\
\hline $1 \mathrm{~A} 10$ & 1189 & 0.87 & 24 & SW & good & lower tundra \\
\hline $1 \mathrm{~A} 11$ & 1097 & 0.87 & 29 & SW & good & upper aspen \\
\hline $1 \mathrm{~A} 12$ & 991 & 1.13 & 15 & SW & good & upper aspen \\
\hline $1 \mathrm{~A} 13$ & 914 & 0.71 & 21 & SW & good & lower aspen \\
\hline $1 \mathrm{~A} 14$ & 869 & 1.18 & $<5$ & SW & good & upper spruce \\
\hline $1 \mathrm{B1}$ & 853 & 1.18 & $<5$ & W & good & lower aspen \\
\hline $1 B 2$ & 945 & 0.96 & 12 & SW & good & upper aspen \\
\hline $1 B 4$ & 1128 & 1.89 & 10 & SW & fair & upper spruce \\
\hline $1 B 5$ & 1219 & 1.34 & 26 & SW & good & upper aspen \\
\hline $1 B 6$ & 1311 & 0.97 & 33 & $S$ & good & lower tundra \\
\hline $1 B 7$ & 1402 & 1.39 & 21 & SW & good & upper willow \\
\hline $1 \mathrm{~B} 9$ & 1584 & 0.94 & 14 & SW & good & upper willow \\
\hline $1 \mathrm{~B} 15$ & 1951 & 0.78 & $<5$ & NE & fair & felsenmeer \\
\hline $1 \mathrm{C} 1$ & 945 & 1.1 & $<5$ & $S$ & fair & lower spruce \\
\hline $1 \mathrm{C} 2$ & 1036 & 1.32 & 12 & $S$ & good & lower aspen \\
\hline $1 C 3$ & 1128 & 1.31 & 28 & S & good & upper aspen \\
\hline $1 \mathrm{C} 4$ & 1219 & 1.57 & 19 & E & good & upper aspen \\
\hline $1 C 5$ & 1311 & 0.82 & 13 & $E$ & good & upper willow \\
\hline $1 \mathrm{C} 6$ & 1372 & 1.03 & 0 & flat & good & upper willow \\
\hline $1 C 7$ & 1402 & 1.15 & 13 & SE & good & upper willow \\
\hline 1D2 & 1661 & 1.02 & 15 & W & good & lower tundra \\
\hline 1D4 & 1829 & 1.32 & 21 & $w$ & good & lower tundra \\
\hline $1 \mathrm{D} 6$ & 1920 & 1 & 0 & flat & good & upper tundra \\
\hline $1 F 2$ & 1798 & 1.16 & 25 & $N$ & good & upper tundra \\
\hline $1 \mathrm{~F} 3$ & 1896 & 1.45 & 16 & NW & good & upper tundra \\
\hline $1 \mathrm{G} 2$ & 2131 & 1.03 & $<5$ & S & good & felsenmeer \\
\hline $1 G 3$ & 2088 & 0.95 & $<5$ & $E$ & good & felsenmeer \\
\hline $1 \mathrm{H} 1$ & 945 & 0.47 & $<5$ & $\mathrm{~s}$ & fair & flood plain \\
\hline $1 \mathrm{H} 2$ & 1036 & 0.78 & 45 & $w$ & good & lower aspen \\
\hline $1 \mathrm{H} 3$ & 1143 & 1.15 & 6 & $\mathrm{~S}$ & good & lower willow \\
\hline $1 \mathrm{H} 4$ & 1219 & 1.39 & 21 & S & good & lower aspen \\
\hline $1 \mathrm{H} 5$ & 1326 & 1.23 & 28 & S & good & upper aspen \\
\hline $1 \mathrm{H} 6$ & 1402 & 1.31 & 8 & S & good & upper willow \\
\hline $1 \mathrm{~J} 1$ & 1128 & 1.64 & 8 & $S$ & good & lower spruce \\
\hline
\end{tabular}


C-2

\begin{tabular}{|c|c|c|c|c|c|c|}
\hline Site \# & Elev.(m) & Iron(\%) & Slope(deg) & Slope Aspect & Drainage & Cover Class \\
\hline $1 \mathrm{~J} 2$ & 1109 & 1.32 & 5 & $\mathrm{~S}$ & good & lower spruce \\
\hline $1 \mathrm{~J} 3$ & 1113 & 1.15 & 9 & $S$ & good & lower spruce \\
\hline $1 \mathrm{~J} 4$ & 1134 & 1.16 & 7 & $S$ & good & lower spruce \\
\hline $1 \mathrm{~K} 2$ & 2316 & 3.08 & 0 & flat & good & felsenmeer \\
\hline $1 \mathrm{~K} 3$ & 2286 & 2.16 & 12 & SW & good & felsenmeer \\
\hline $1 \mathrm{~K} 5$ & 2225 & 2.09 & 10 & S & good & upper tundra \\
\hline $1 \mathrm{~K} 7$ & 2103 & 2.45 & 18 & SE & good & upper tundra \\
\hline $1 \mathrm{~K} 8$ & 2134 & 1.81 & 43 & w & good & upper tundra \\
\hline $1 \mathrm{~K} 10$ & 2195 & 2.45 & 34 & $E$ & good & felsenmeer \\
\hline $1 \mathrm{M} 1$ & 823 & 0.75 & 19 & W & good & floodplain \\
\hline $1 \mathrm{M} 2$ & 838 & 1.11 & $<5$ & SW & good & floodplain \\
\hline $1 \mathrm{M} 3$ & 805 & 0.7 & 16 & SW & good & floodplain \\
\hline $1 \mathrm{M} 4$ & 860 & 0.49 & 18 & S & good & floodplain \\
\hline
\end{tabular}

